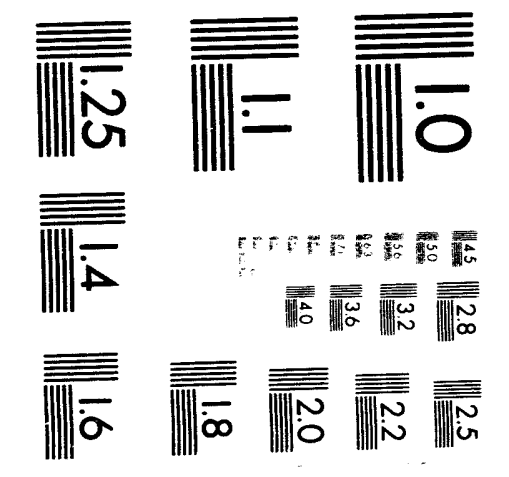



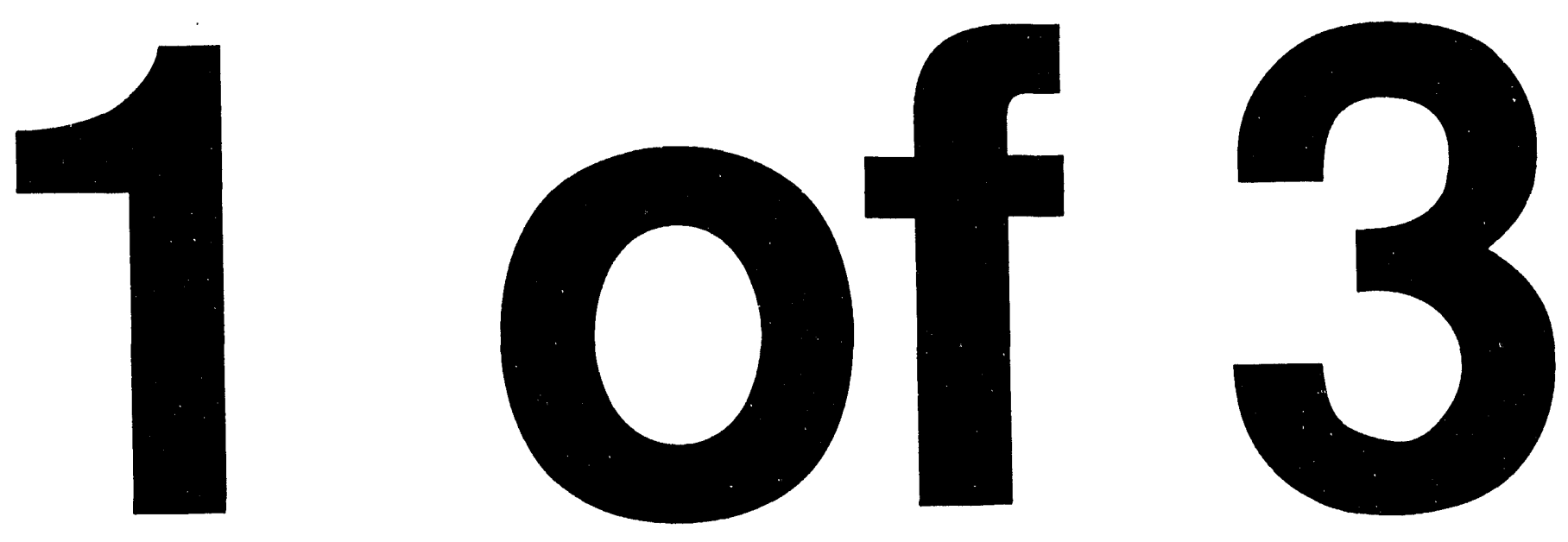
ORNL/TM-11433/R3

Waste Management and Remedial Action Division

\title{
OAK RIDGE NATIONAL LABORATORY WASTE MANAGEMENT PLAN
}

FISCAL YEAR 1994

\author{
Plan Coordinator \\ R. E. Pudelek \\ Editor \\ J. W. Turner
}

Date Published-December 1993

Prepared by the

Waste Management and Remedial Action Division Staff for the

Office of Environmental Restoration and Waste Management

Budget Activity Nos. EW 3120043 and EX 3120011

OAK RIDGE NATIONAL LABORATORY

Oak Ridge, Tennessee 37831-6285

managed by

MARTIN MARIETTA ENERGY SYSTEMS, INC.

for the

U.S. DEPARTMEN' OF ENERGY

under contract DE-AC05-84OR21400 


\section{CONTENTS}

Page

LIST OF FIGURES $\ldots \ldots \ldots \ldots \ldots \ldots \ldots \ldots \ldots \ldots \ldots \ldots \ldots$

LIST OF TABLES $\ldots \ldots \ldots \ldots \ldots \ldots \ldots \ldots \ldots \ldots \ldots \ldots \ldots \ldots \ldots$

ACRONYMS AND INITIALISMS $\ldots \ldots \ldots \ldots \ldots \ldots \ldots \ldots \ldots \ldots \ldots \ldots$

ACKNOWLEDGMENTS $\ldots \ldots \ldots \ldots \ldots \ldots \ldots \ldots \ldots \ldots \ldots \ldots \ldots$

EXECUTIVE SUMMARY $\ldots \ldots \ldots \ldots \ldots \ldots \ldots \ldots \ldots \ldots \ldots \ldots \ldots$

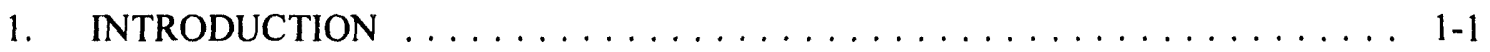

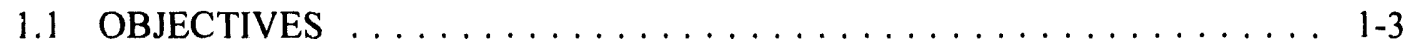

1.2 PURPOSE ................................

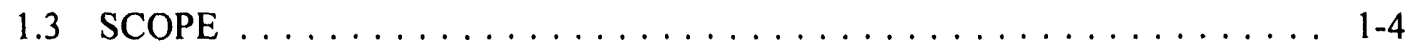

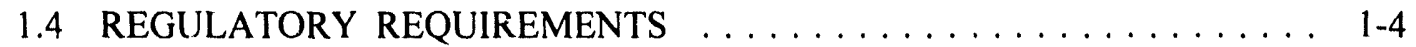

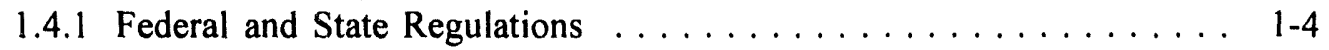

1.4.2 DOE Orders . . . . . . . . . . . . . . . . . . . 1-7

1.5 OVERALL GOALS $\ldots \ldots \ldots \ldots \ldots \ldots \ldots \ldots \ldots \ldots \ldots \ldots \ldots$

2. GENERAL SITE INFORMATION $\ldots \ldots \ldots \ldots \ldots \ldots \ldots \ldots \ldots \ldots \ldots \ldots$ 2-1

2.1 ORGANIZATION AND ADMINISTRATION $\ldots \ldots \ldots \ldots \ldots \ldots \ldots . \ldots 2-3$

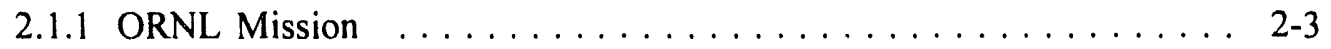

2.1.2 Historical Development of Waste Management at ORNL . . . . . . 2 2-3

2.1.3 Waste Management Organizational Structures . . . . . . . . . . 2 2-4

2.2 DOCUMENTATION ....................... 2-11

2.2.1 ORNL Waste Management Guidance and Support Documents . . . . 2-11

2.2.2 Documentation Management Center ... . . . . . . . . . . . 2-13

2.3 SITE DESCRIPTION . . . . . . . . . . . . . . . . . 2-14

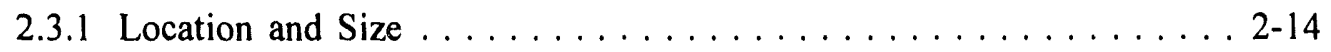

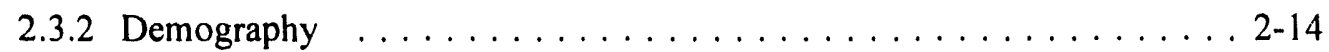

2.3 .3 Site Topography . . . . . . . . . . . . . . . . 2-15

2.3 .4 Climate .......................... 2-16

2.3.5 Geologic and Hydrogeologic Conditions . . . . . . . . . . 2-17

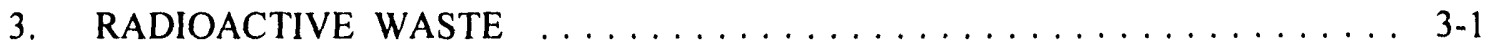

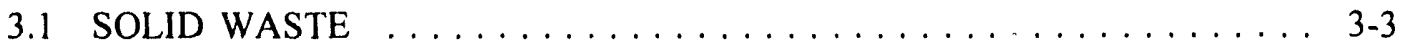

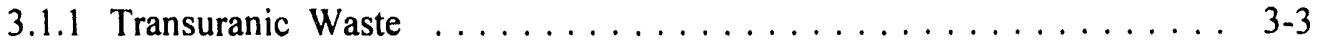

3.1 .2 Solid Low-Level Waste . . . . . . . . . . . . . . . . 3-20

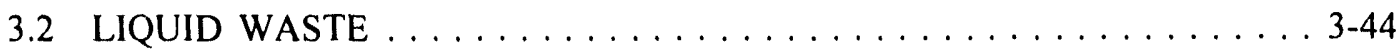

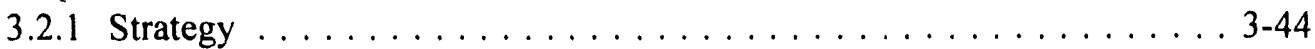

3.2.2 Liquid Low-Level Waste System . . . . . . . . . . . . 3-45

3.2 .3 Process Waste System . . . . . . . . . . . . . . . 3-65

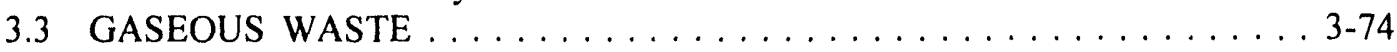

3.3 .1 Strategy . . . . . . . . . . . . . . . . . . . 3-74

3.3.2 Generic Description and Characteristics of Waste . . . . . . 3-76 
3.3.3 Treatment Facilities . . . . . . . . . . . . . . . . 3-76

3.3.4 Storage and Disposal Facilities . . . . . . . . . . . . . 3-89

3.3.5 Status of Support Systems . . . . . . . . . . . . . . . 3-90

3.3.6 General Plant Projects . . . . . . . . . . . . . . . . 3-90

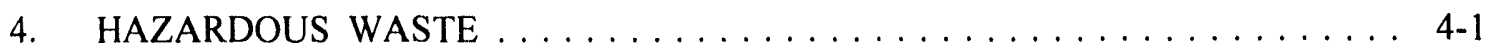

4.1 SOLID AND LIQUID WASTES $\ldots \ldots \ldots \ldots \ldots \ldots \ldots \ldots \ldots \ldots$ 4-3

4.1 .1 Strategy . . . . . . . . . . . . . . . . . . . . 4-4

4.1.2 Generic Description and Characteristics of Waste ........ 4-5

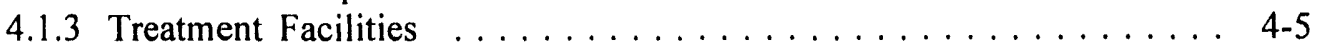

4.1 .4 Storage Facilities $\ldots \ldots \ldots \ldots \ldots \ldots \ldots \ldots \ldots \ldots$ 4-7

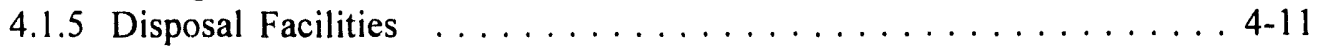

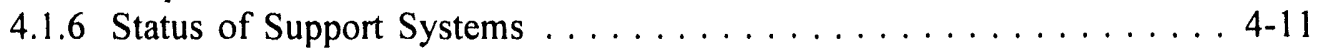

4.1 .7 General Plant Projects . . . . . . . . . . . . . . . 4-13

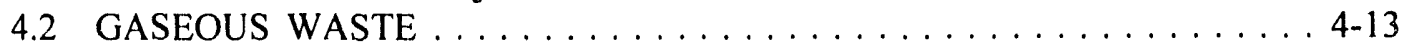

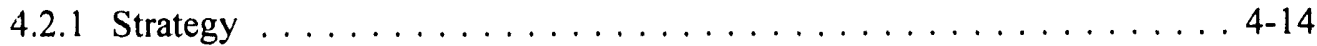

4.2.2 Generic Description and Characteristics of Waste . . . . . . . . 4-14

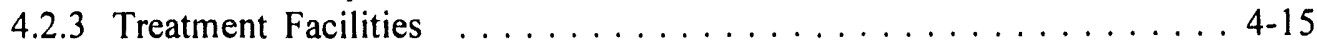

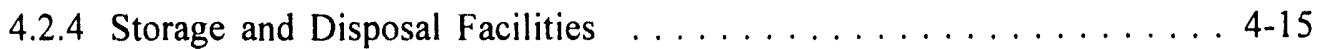

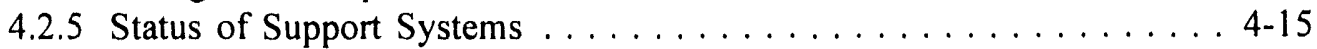

4.2.6 General Plant Projects . . . . . . . . . . . . . 4-15

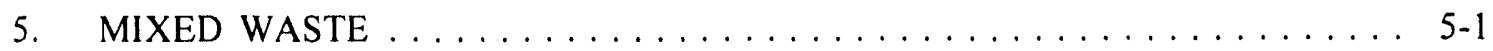

5.1 SOLID AND LIQUID WASTES $\ldots \ldots \ldots \ldots \ldots \ldots \ldots \ldots \ldots \ldots \ldots$

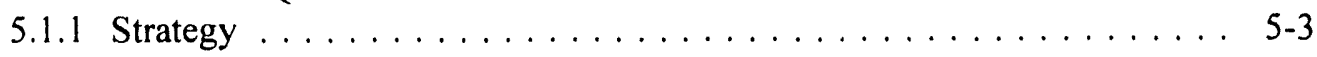

5.1.2 Generic Description and Characteristics of Waste ........ 5-4

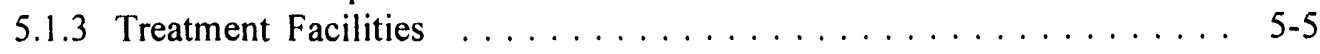

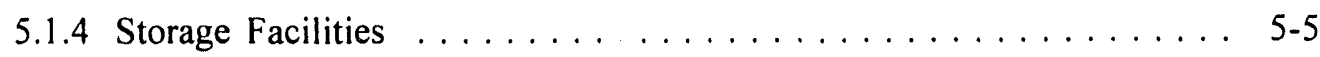

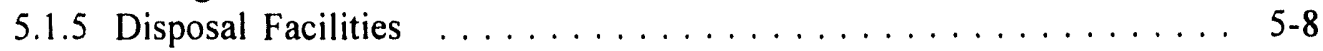

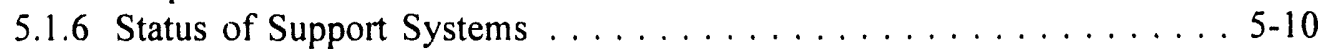

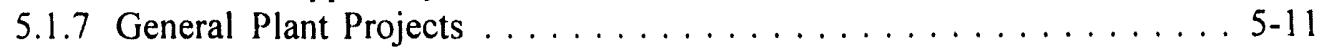

5.2 GASEOUS WASTE ....................... 5-11

6. INDUSTRIAL AND SANITARY WASTES $\ldots \ldots \ldots \ldots \ldots \ldots \ldots \ldots \ldots$. $\ldots \ldots$

6.1 INDUSTRIAL WASTE $\ldots \ldots \ldots \ldots \ldots \ldots \ldots \ldots \ldots \ldots \ldots$

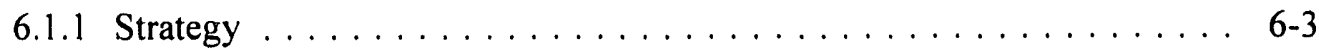

6.1.2 Types of Industrial Wastes at Oak Ridge National $6-3$

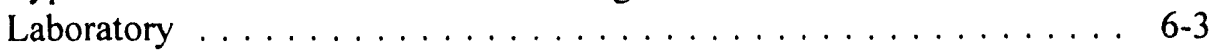

6.1.3 Industrial Waste Treatment and Storage at

Oak Ridge National Laboratory . . . . . . . . . . . . . . . . 6- 6-4

6.1 .4 Existing and Future Disposal Facilities . . . . . . . . . . 6. 6-5

6.1 .5 Status of Support Systems $\ldots \ldots \ldots \ldots \ldots \ldots \ldots \ldots$ 6-7

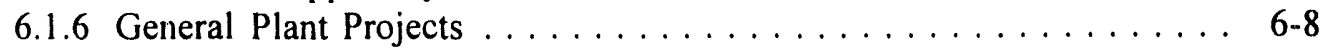

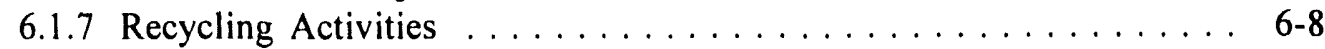

6.2 SANITARY WASTE $\ldots \ldots \ldots \ldots \ldots \ldots \ldots \ldots \ldots \ldots \ldots \ldots$

6.2 .1 Strategy .......................... 6-11

6.2.2 Characteristics of Sanitary Wastewater .............. 6-11

6.2.3 Sanitary Wastewater Treatment Facility . . . . . . . . . . . 6-13

6.2 .4 Storage and Disposal Facilities $\ldots \ldots \ldots \ldots \ldots$ 6-15 
6.2.5 Status of Support Systems . . . . . . . . . . . . . 6-16

6.2.6 Line Item and General Plant Projects . . . . . . . . . . . . 6-16

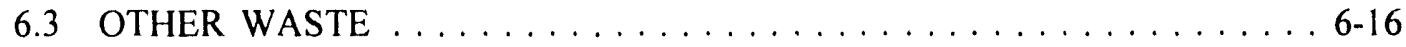

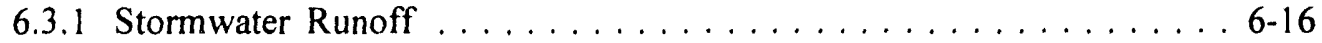

6.3.2 Once-Through Cooling Water ............... 6-17

6.3.3 Cooling Tower Blowdown .................. . . 6-17

6.3.4 Effluent from Coalyard Runoff Treatment Facility . . . . . . . . . 6-20

7. DECONTAMINATION AND DECOMMISSIONING $\ldots \ldots \ldots \ldots \ldots \ldots \ldots$

7.1 OPERATIONAL FACILITIES $\ldots \ldots \ldots \ldots \ldots \ldots \ldots \ldots \ldots \ldots$

7.2 INACTIVE FACILITIES $\ldots \ldots \ldots \ldots \ldots \ldots \ldots \ldots \ldots \ldots \ldots \ldots$

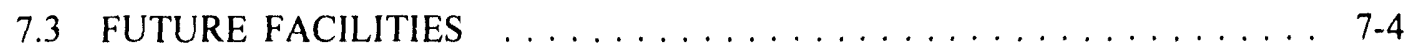

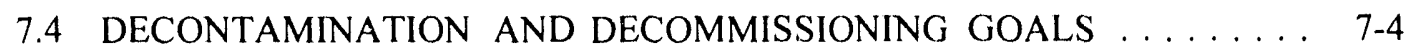

7.5 UPDATE OF IMPLEMENTATION SUMMARY TABLE $\ldots \ldots \ldots \ldots .7-5$

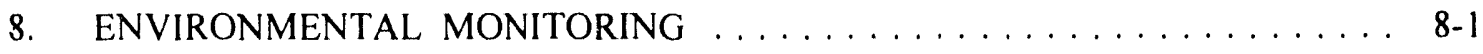

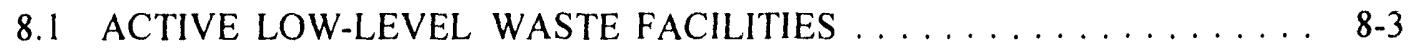

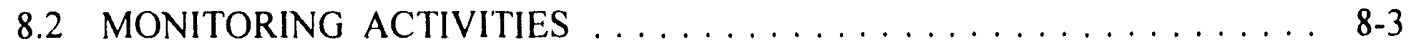

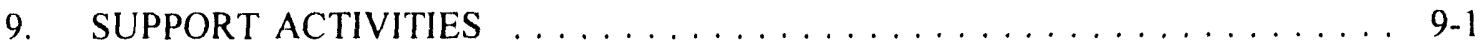

9.1 STORAGE, TREATMENT, AND DISPOSAL PLAN . . . . . . . . . 9-3

9.2 WASTE REDUCTION $\ldots \ldots \ldots \ldots \ldots \ldots \ldots \ldots \ldots \ldots \ldots$

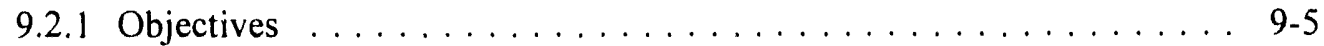

9.2 .2 Strategy . . . . . . . . . . . . . . . . . . 9-5

9.2 .3 Goals . . . . . . . . . . . . . . . . . . . . . . . . . . 9-5

9.2.4 Regulatory Requirements . . . . . . . . . . . . . . . . 9.7

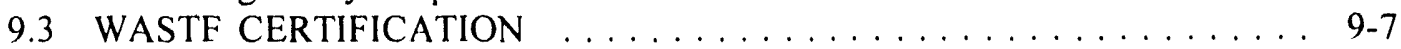

9.3.1 Historical Development . . . . . . . . . . . . . . . . 9-7

9.3.2 Future Direction ... . . . . . . . . . . . . . . . . 9-8

9.4 WASTE MANAGEMENT PLANNING ACTIVITIES . . . . . . . . . . 9-9

9.4.1 Strategic Planning . . . . . . . . . . . . . . . . . . . . . 9 9-9

9.4.2 Long-Range Planning . . . . . . . . . . . . . . 9-10

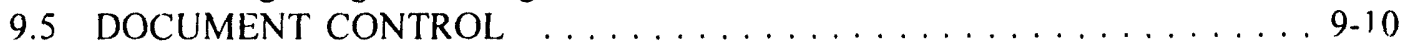

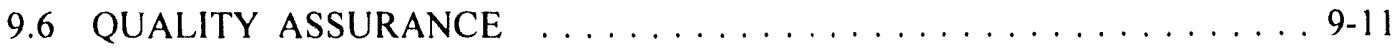

9.7 NATIONAL ENVIRONMENTAL POLICY ACT COMPLIANCE

AND DOCUMENTATION ................... $9-12$

9.7.1 Action Description Memorandum . . . . . . . . . . . . 9-12

9.7.2 Environmental Assessment . . . . . . . . . . . . . . 9-12

9.7.3 Environmental Impact Statement . . . . . . . . . . . . . 9-13

9.7.4 Categorical Exclusion Determination . . . . . . . . . . . . 9-13

9.7.5 Finding of No Significant Impact . . . . . . . . . . . . . . . . 9-13

9.7.6 Record of Decision . . . . . . . . . . . . . . . . . . . . 9-13

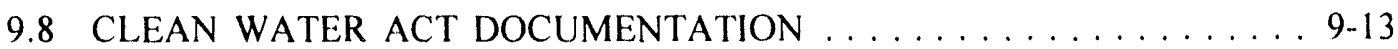

9.8.1 National Pollutant Discharge Eiimination System Permit . . . . . . 9 9-13

9.8.2 Best Management Practices Plan ... . . . . . . . . . . 9-14

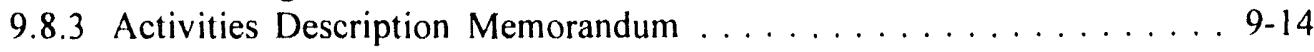

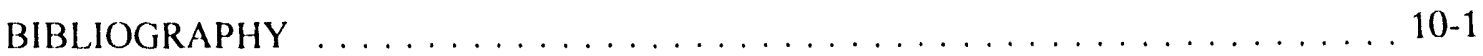


APPENDIX A: DOE ORDER 5820.2A IMPLEMENTATION SUMMARY $\ldots \ldots \ldots$ A-1 APPENDIX B: WASTE MANAGEMENT DOCUMENTATION REQUIREMENTS ..................... B-1 APPENDIX C: ORNL WASTE TREATMENT, STORAGE, AND DISPOSAL

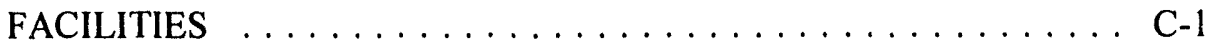




\section{LIST OF FIGURES}

Higure Page

2.I U.S. Department of Energy Headquarters: organizational overview .......................... 2-5

2.2 AMERWM organization for the U.S. Department of Energy's

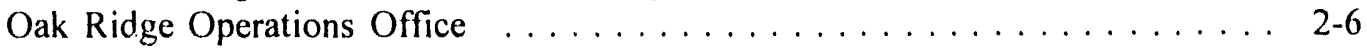

2.3 Organizational overview for the Energy Systems Environmental

Restoration, Decontamination and Decommissioning, and Waste

Management Programs ........................ 2-7

2.4 Energy Systems Waste Management Organization $\ldots \ldots \ldots \ldots \ldots \ldots \ldots \ldots$ 2-8

2.5 Organization of the Waste Management and Remedial Action

Division at Oak Ridge National Laboratory . . . . . . . . . . . . . . . 2-9

2.6 Organization of the Office of Environmental Compliance and

Documentation at Oak Ridge National Laboratory ............. 2-11

2.7 Area map indicating location of Oak Ridge National Laboratory . . . . . . 2 2-15

2.8 Layout of the central Oak Ridge National Laboratory Complex in

Bethel Valley .......................... 2-16

2.9 Geologic formations within the Oak Ridge Reservation $\ldots \ldots \ldots \ldots \ldots \ldots$

3.1 Decision tree for segregation and disposition of solid

radioactive waste at Oak Ridge National Laboratory . . . . . . . . . . . 3-3

3.2 Location of radioactive solid waste treatment, storage, and

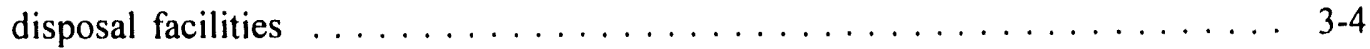

3.3 Transuranic waste storage facilities in the north area of

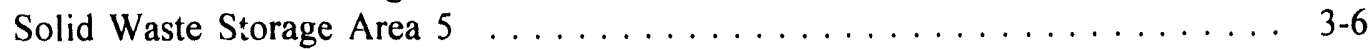

3.4 Flow sheet for handling newly generated contact-handled

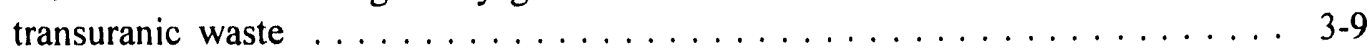

3.5 Conceptual Waste Handling and Packaging Plant cutaway .......... 3-12

3.6 Waste Handling and Packaging Plant site and its relationship

to main Oak Ridge National Laboratory Complex and other

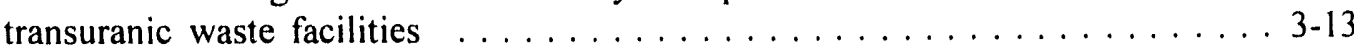

3.7 Locations of transuranic waste storage and disposal facilities

in the north area of Solid Waste Storage Area $5 \ldots \ldots \ldots \ldots$ 3-14 
3.8 Front elevation view of a typical remote-handled transuranic storage bunker (Building 7883) . . . . . . . . . . . . . . . . . 3-17

3.9 Projected availability of low-level waste storage and disposal facilities . . . . 3-21

3.10 Location of Solid Waste Storage Area 6 disposal units . . . . . . . . . . 3-34

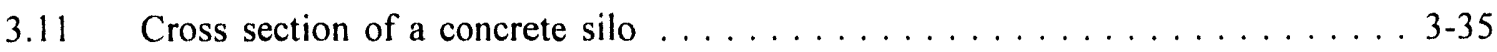

3.12 Cross section of a concrete silo having high-range wells $\ldots \ldots \ldots \ldots \ldots$ 3-37

3.13 Cross section of a high-range well $\ldots \ldots \ldots \ldots \ldots \ldots \ldots \ldots \ldots \ldots$

3.14 Generic concrete cask for tumulus disposal operations $\ldots \ldots \ldots \ldots \ldots \ldots$ 3-41

3.15 Interim Waste Management Facility depiction showing vaults of solid low-level waste, drain lines, and final cover . . . . . . . . . . . . 3-43

3.16 Liquid waste management strategy $\ldots \ldots \ldots \ldots \ldots \ldots \ldots \ldots \ldots \ldots \ldots$

3.17 Existing and proposed facilities for liquid low-level waste,

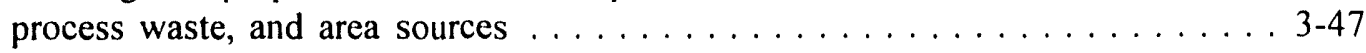

3.18 Liquid Low-Level Waste System description $\ldots \ldots \ldots \ldots \ldots \ldots \ldots$

3.19 Location of Waste Management Operation's active liquid low-level

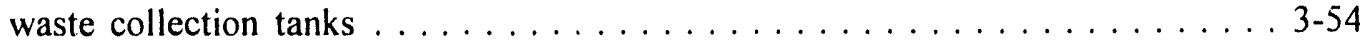

3.20 Liquid Low-Level Waste Collection, Treatment, and Storage System . . . . 3-57

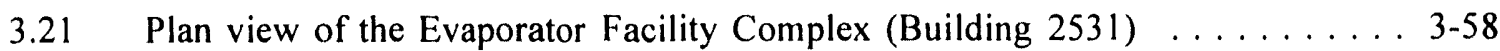

3.22 Process Waste System . . . . . . . . . . . . . . . 3-67

3.23 Process flow diagram of the Process Waste Treatment Plant $\ldots \ldots \ldots \ldots$ 3-68

3.24 Flow diagram of the Nonradiological Wastewater Treatment Plant . . . . . 3 3-69

3.25 Radioactive gaseous waste emission control . . . . . . . . . . . . 3-75

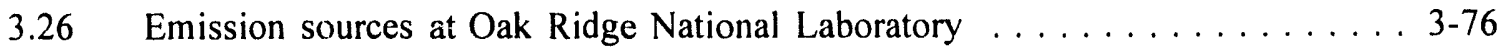

Location of major cell ventilation stacks at Oak Ridge
National Laboratory $\ldots \ldots \ldots \ldots \ldots \ldots \ldots \ldots \ldots \ldots \ldots \ldots \ldots$

3.28 Oak Ridge National Laboratory's Central Ventilation System for Bethel Valley facilities $(3039$ stack) . . . . . . . . . . . . . . 3-79

3.29 Oak Ridge National Laboratory's Central Ventilation System for Melton Valley facilities $(7911$ stack) $\ldots \ldots \ldots \ldots \ldots \ldots \ldots \ldots$ 3-80 
3.30 Ventilation System for the Radiochemical Processing Pilot Plant (3020 stack) . . . . . . . . . . . . . . . . . . . . . . 3-81

3.31 Ventilation System for the High-Radiation-Level Analytical Laboratory (2026 stack)

3.32 Ventilation System for Molten Salt Reactor Experiment (7512 stack) . . . . . 3-83

3.33 Ventilation System for Oak Ridge Electron Linear Accelerator

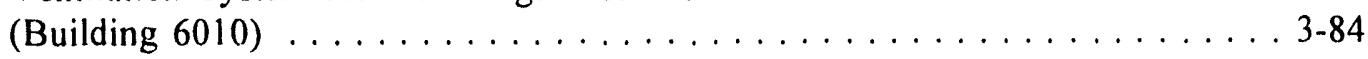

3.34 Ventilation System for Tritium Target Fabrication Facility

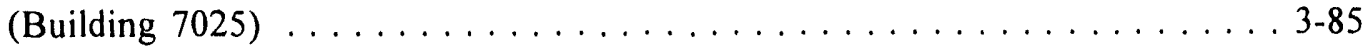

3.35 Ambient air-monitoring locations at Oak Ridge National Laboratory . . . . . . 3-87

4.1 Oak Ridge National Laboratory management strategy for hazardous waste $\ldots \ldots \ldots \ldots \ldots \ldots \ldots \ldots \ldots \ldots . \ldots \ldots$ 4. $\ldots \ldots \ldots$

4.2 Flowchart of hazardous waste management activities $\ldots \ldots \ldots \ldots \ldots \ldots$. . . .

4.3 Chemical Detonation Facility (Building 7667) $\ldots \ldots \ldots \ldots \ldots \ldots \ldots$

4.4 Layout of the Hazardous Waste Storage Facility (Building 7652) . . . . . 4 4-8

4.5 Layout of the Chemical Waste Storage Facility (Building 7653) . . . . . 4 4-9

4.6 Layout of the Hazardous Waste Storage Facility (Building 7507) . . . . . 4-10

4.7 Layout of the Clean Oil Storage Pad (Building 7651) . . . . . . . . 4-10

5.1 Oak Ridge National Laboratory management strategy for mixed waste $\ldots . . .5-4$

5.2 Layout of the Long-Term Hazardous Waste Storage Facility

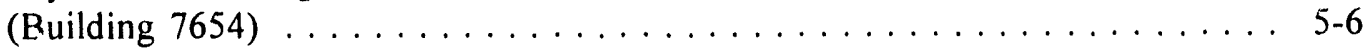

5.3 Layout of the Mixed Waste Storage Pad (Building 7507W) $\ldots \ldots \ldots \ldots \ldots$

6.1 Strategy for Oak Ridge National Laboratory industrial waste $\ldots \ldots \ldots \ldots \ldots$. . . . 6-4

6.2 Flow diagram of the Coal Yard Runoff Treatment Facility . . . . . . . . . 6-5

6.3 Proposed and existing landfill locations at the Oak Ridge $Y-12$ Plant . . . . 6-6

6.4 Quarterly, yearly, and cumulative values in tons for corrugated boxboard recycled at Oak Ridge National Laboratory during 1991, 1992, and 1993 
6.5 Quarterly, yearly, and cumulative values in tons for white paper recycled at Oak Ridge National Laboratory during 1991, 1992,

and 1993

6.6 Quarterly, yearly, and cumulative values in tons for aluminum cans recycled at Oak Ridge National Laboratory during 1991, 1992, and 1993

6.7 Quarterly, yearly, and cumulative values in tons for phone books recycled at Oak Ridge National Laboratory during 1991, 1992,

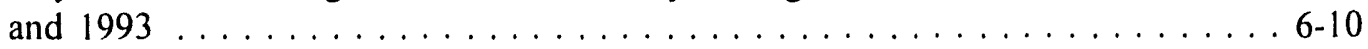

6.8 Quarterly, yearly, and cumulative numerical totals for toner cartridges recycled at Oak Ridge National Laboratory during 1991, 1992, and 1993

6.9 Block flow diagram for the Sewage Treatment Plant . . . . . . . . . 6-12

6.10 Fifth Creek storm sewer outfalls $\ldots \ldots \ldots \ldots \ldots \ldots \ldots \ldots \ldots \ldots$

6.11 First Creek storm sewer outfalls $\ldots \ldots \ldots \ldots \ldots \ldots \ldots \ldots \ldots$

6.12 White Oak Creek storm sewer outfalls $\ldots \ldots \ldots \ldots \ldots \ldots \ldots$ 6-19 


\section{LIST OF TABLES}

Table

Page

2.1 Oak Ridge National Laboratory waste management Activity Data

Sheets for FY 1995 and related regulatory drivers . . . . . . . . . . 2-13

3.1 Line item and general plant projects for transuranic waste facilities at Oak Ridge National Laboratory . . . . . . . . . . . . . . . . 3-19

3.2 Current solid low-level waste (SLLW) segregation categories $\ldots \ldots \ldots \ldots \ldots$ 3-22

3.3 Disposal methods for waste disposed of in Solid Waste Storage

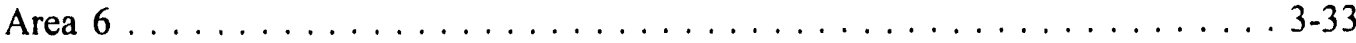

3.4 Line item and general plant projects for solid low-level waste facilities at Oak Ridge National Laboratory . . . . . . . . . . . . . . . . 3-45

3.5 Dilute liquid low-level waste (LLLW) generation: 1992 and $1993 \ldots \ldots$. . . 3.-50

3.6 Liquid low-level waste concentrate generation: 1992 and $1993 \ldots \ldots \ldots$. . . . 3-51

3.7 Liquid low-level waste active collection tank capacities and source buildings at Oak Ridge National Laboratory . . . . . . . . . . . 3-55

3.8 Liquid low-level waste concentrate storage tank capacities and

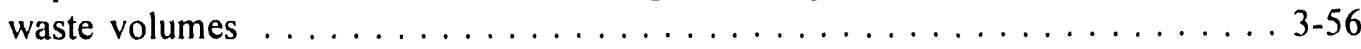

3.9 Federal Facilities Agreement (FFA) requirements for Oak Ridge National Laboratory Liquid Low-Level Waste (LLLW) Tank System . . . . . . . . . . . 3-61

3.10 Facilities supported by active liquid low-level waste tanks $\ldots \ldots \ldots \ldots \ldots$ 3-62

3.11 Line item and general plant projects for the Liquid Low-Level Waste System at Oak Ridge National Laboratory . . . . . . . . . . . 3-65

3.12 National Pollutant Discharge Elimination System permit limits vs Water Quality Standards . . . . . . . . . . . . . . . . . . . 3-71

3.13 Line item and general plant projects for the Process Waste System at Oak Ridge National Laboratory . . . . . . . . . . . . . . . 3-74

3.14 Minor sources of radiological gases emitted from Oak Ridge National Laboratory facilities

3.15 General plant projects for gaseous radioactive waste facilities at Oak Ridge National Laboratory 
4.1 General plant project for hazardous waste facilities at Oak Ridge National Laboratory . . . . . . . . . . . . . . . . . . . . . . . 4-14

5.1 Solid waste generated and handled at Oak Ridge National Laboratory

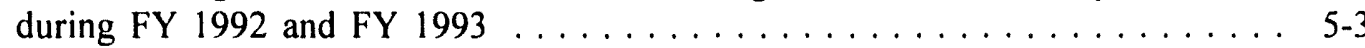

5.2 Oak Ridge National Laboratory land disposal restriction mixed waste with identified existing treatment $\ldots \ldots \ldots \ldots \ldots \ldots \ldots \ldots \ldots \ldots \ldots$

5.3 Oak Ridge National Laboratory land disposal restriction mixed waste without identified existing treatment $\ldots \ldots \ldots \ldots \ldots \ldots \ldots \ldots$ 5-10

5.4 General plant projects for mixed waste facilities at Oak Ridge National Laboratory . . . . . . . . . . . . . . . . . . . . . . . 5-11

6.1 Line item and general plant projects for sanitary wastewater facilities at Oak Ridge National Laboratory . . . . . . . . . . . . . 6-16

7.1 Facilities included in the Decontamination and Decommissioning Program since 1976

7.2 Former Energy Research-supported surplus facilities expected to be transferred to the Decontamination and Decommissioning Program in FY 1993

7.3 Former Energy Research-supported surplus facilities not meeting Decontamination and Decommissioning Program acceptance criteria . . . . . 7-6

7.4 Facilities or sites under the Environmental Restoration Program . . . . . . . . 7-7

7.5 Decommissioning of surplus facilities: long-range schedule $\ldots \ldots \ldots \ldots$ 7-8

9.1 Planned storage facility construction/upgrades $\ldots \ldots \ldots \ldots \ldots \ldots \ldots$

9.2 Oak Ridge National Laboratory waste minimization/reduction goals $\ldots \ldots \ldots$ 9-6

9.3 Document Management System levels $\ldots \ldots \ldots \ldots \ldots \ldots \ldots \ldots \ldots$ 


\section{ACRONYMS AND INITIALISMS}

\begin{tabular}{|c|c|}
\hline AcDM & Activities Description Memorandum \\
\hline ADM & Action Description Memorandum \\
\hline ADS & Activity Data Sheet \\
\hline AEA & Atomic Energy Act \\
\hline ALARA & as low as reasonably achievable \\
\hline AMERD & Assistant Manager for Energy Research and Development \\
\hline AMERWM & Assistant Manager for Environmental Restoration and Waste Management \\
\hline ANS & Advanced Neutron Source \\
\hline ANSI & American National Standards Institute \\
\hline ARAR & Applicable or Relevant and Appropriate Requirement \\
\hline ASME & Americar: Society of Mechanical Engineers \\
\hline BAT & Best Available Technology \\
\hline BMP & Best Management Practices \\
\hline CAA & Clean Air Act \\
\hline CAT & collection and transfer \\
\hline CDR & Conceptual Design Report \\
\hline CEQ & Council on Environmental Quality \\
\hline CERCLA & Comprehensive Environmental Response, Compensation, and Liability Act \\
\hline CFR & Code of Federal Regulations \\
\hline $\mathrm{CH}$ & contact-handled \\
\hline COM & commercially held, DOE-owned radioactive material \\
\hline COR & contractor officer's representative \\
\hline $\mathrm{CV}$ & cell ventilation \\
\hline CWA & Clean Water Act \\
\hline $\mathrm{CWCH}$ & central waste collection header \\
\hline CWMD & Central Waste Management Division \\
\hline CY & current year \\
\hline CYRTF & Coal Yard Runoff Treatment Facility \\
\hline CYRTS & Coal Yard Runoff Treatment System \\
\hline CYWP & Current Year Work Plan \\
\hline $\mathrm{D} \& \mathrm{D}$ & decontamination and decommissioning \\
\hline DDDP & Defense Decontamination and Decommissioning Program \\
\hline DMC & Documentation Management Center \\
\hline DMS & Documentation Management System \\
\hline DOE & U.S. Department of Energy \\
\hline DOE-HQ & U.S. Department of Energy, Headquarters \\
\hline DOE-ORO & U.S. Department of Energy, Oak Ridge Operations Office \\
\hline DOT & U.S. Department of Transportation \\
\hline DP & Defense Programs \\
\hline EA & Environmental Assessment \\
\hline EASC & Emergency Avoidance Solidification Campaign \\
\hline EIS & Environmental Impact Statement \\
\hline EM & DOE's Environmental Restoration and Waste Management Program \\
\hline EPA & U.S. Environmental Protection Agency \\
\hline ER & environmental restoration \\
\hline ERP & Environmental Restoration Program \\
\hline
\end{tabular}




\begin{tabular}{|c|c|}
\hline ERW & environmental remediation waste \\
\hline ES\&H & Environmental, Safety, and Health (Protection Division) \\
\hline ESWMO & Energy Systems Waste Management Organization \\
\hline FFA & Federal Facilities Agreement \\
\hline FFCA & Federal Facilities Compliance Agreement \\
\hline FFCAct & Federal Facilities Compliance Act \\
\hline FY & fiscal year \\
\hline GCD & greater confinement disposal \\
\hline GPP & general plant project \\
\hline GTCC & greater than Class $\mathrm{C}$ \\
\hline G-M & Geiger-Mueller \\
\hline HAZWDDD & Hazardous Waste Development, Demonstration, and Disposal (Program) \\
\hline HDTF & Hillcut Disposal Test Facility \\
\hline HEPA & high-efficiency particulate air (filter) \\
\hline HFIR & High Flux Isotope Reactor \\
\hline HLI & high-level incidental waste \\
\hline HLW & high-level waste \\
\hline HPRR & Health Physics Research Reactor \\
\hline HRLAL & High-Radiation-Level Analytical Laboratory \\
\hline HRLEL & High-Radiation-Level Examination Laboratory \\
\hline HSWA & Hazardous and Solid Waste Amendments \\
\hline HWMA & Hazardous Waste Management Area \\
\hline HWOG & Hazardous Waste Operations Group \\
\hline HWTS & Hazardous Waste Tracking System \\
\hline ITE & in-tank evaporation \\
\hline IWMF & Interim Waste Management Facility \\
\hline LDR & land disposal restrictions \\
\hline LGWOD & Liquid and Gaseous Waste Operations Department \\
\hline $\mathrm{LI}$ & line item \\
\hline LLLW & liquid low-level waste \\
\hline LLW & low-level waste \\
\hline LLWDDD & Low-Level Waste Disposal Development and Demonstration (Program) \\
\hline LRP & ORNL Waste Management Long-Range Plan \\
\hline LWSP & Liquid Waste Solidification Project \\
\hline MVST & Melton Valley storage tank \\
\hline NARM & naturally occurring and accelerator-produced radioactive material \\
\hline NCP & National Contingency Plan \\
\hline NDA & nondestructive assay \\
\hline NDE & nondestructive examination \\
\hline NEPA & National Environmental Policy Act \\
\hline NESHAP & National Emission Standards for Hazardous Air Pollutants \\
\hline NFS & Nuclear Fuel Services \\
\hline NG & newly generated \\
\hline NHF & New Hydrofracture Facility \\
\hline NPDES & National Pollutant Discharge Elimination System \\
\hline NPL & National Priorities List \\
\hline NRC & Nuclear Regulatory Commission \\
\hline NRWTP & Nonradiological Wastewater Treatment Plant \\
\hline $\mathrm{OHF}$ & Old Hydrofracture Facility \\
\hline
\end{tabular}




\section{ACKNOWLEDGMENTS}

This document would not have been possible without the timely and knowledgeable input from the following individuals: H. L. Adair, P. E. Arakawa, T. W. Burwinkle, D. L. Daugherty, S. M. Depaoli, J. R. Forgy, Jr., J. K. Gilpin, L. V. Hamilton, S. C. Howard, R. J. Hydzik, T. E. Kent, N. J. Lowe, S. C. Lyttle, C. A. Manrod, B. C. McClelland,

S. R. C. Michaud, S. H. Reece, S. M. Robinson, P. H. Roush, S. T. Rudell, C. B. Scott, L. R. Simmons, J. R. Trabalka, M. W. Tull, D. W. Turner, J. W. Turner, and D. M. Wasserman. Thank you for your time and effort. 



\section{EXECUTIVE SUMMARY}

U.S. Department of Energy (DOE) Order 5820.2A was promulgated in final form on September 26, 1988. The order requires heads of field organizations to prepare and to submit updates on the waste management plans for all operations under their purview according to the format in Chap. VI, "Waste Management Plan Outline." These plans are to be submitted by the DOE Oak Ridge Operations Office (DOE-ORO) in December of each year and distributed to the DP-12, ES\&H-1, and other appropriate DOE Headquarters (DOE-HQ) organizations for review and comment. This document was prepared in response to this requirement for fiscal year (FY) 1994.

The Oak Ridge National Laboratory (ORNL) waste management mission is reduction, collection, storage, treatment, and disposal of DOE wastes, generated primarily in pursuit of ORNL missions, in order to protect human health and safety and the environment. In carrying out this mission, waste management staff in the Waste Management and Remedial Action Division (WMRAD) will (1) guide ORNL in optimizing waste reduction and waste management capabilities and (2) conduct waste management operations in a compliant, publicly acceptable, technically sound, and cost-efficient manner. Waste management requirements for DOE radioactive wastes are detailed in DOE Order 5820.2A, and the ORNL Waste Management Program encompasses all elements of this order. The requirements of this DOE order and other appropriate DOE orders, along with applicable Tennessee Department of Environment and Conservation (TDEC) and U.S. Environmental Protection Agency (EPA) rules and regulations, provide the principal source of regulatory guidance for waste management operations at ORNL.

The objective of this document is compilation and consolidation of information on how the ORNL Waste Management Program is conducted, which waste management facilities are being used to manage wastes, what forces are acting to change current waste management systems, what activities are planned for FY 1994, and how all of the activities are documented.

\section{ORNL WASTE MANAGEMENT ACTIVITIES}

Waste management operations are activities that minimize, treat, store, recycle, or dispose of all radioactive, hazardous, mixed, industrial, and sanitary wastes generated as a result of operations at active and inactive facilities. Routine waste management operations at ORNL are the direct responsibility of WMRAD. The table on the following page shows the quantities of waste generated and handled at ORNL during FY 1992 and FY 1993. In addition to newly generated (NG) wastes, significant quantities of transuranic (TRU) waste and some solid low-level waste (SLLW) and mixed waste from past operations have been placed in long-term retrievable storage.

\section{Radioactive Waste Management}

ORNL radioactive waste management activities primarily involve TRU waste and low-level waste (LLW). Small quantities of naturally occurring and accelerator-produced radioactive material are generated and managed as LLW. ORNL does not generate highlevel waste but does store a small quantity of other highly radioactive material as special case (SC) waste such as spent nuclear fuel. Stored TRU waste consists of sludge primarily from previous operations and lesser volumes of hot-cell-derived waste. Only small amounts 


\begin{tabular}{lll}
\multirow{2}{*}{ Waste stream } & \multicolumn{2}{c}{ Quantity } \\
\cline { 2 - 3 } Transuranic & \multicolumn{1}{c}{$\mathrm{FY} 1992^{\mathrm{a}}$} & \multicolumn{1}{c}{$\mathrm{FY} 1993^{b}$} \\
\hline \multirow{2}{*}{ Solid low-level } & $551 \mathrm{~m}^{3}$ & $68 \mathrm{ft}^{3}$ \\
& $2,915 \mathrm{~m}^{3}$ & $2,399 \mathrm{ft}^{3}$ \\
Liquid low-level & $103,007 \mathrm{ft}^{3}$ & $1,663 \mathrm{~m}^{3}$ \\
Process liquid & $1,558 \mathrm{~m}^{3}$ & $58,775 \mathrm{ft}^{3}$ \\
& $411,510 \mathrm{gal}$ & $1,666 \mathrm{~m}^{3}$ \\
Nonradiological liquid & $264,000 \mathrm{~m}^{3}$ & $440,120 \mathrm{gal}$ \\
& $69,760,000 \mathrm{gal}$ & $257,400 \mathrm{~m}^{3}$ \\
Hazardous & $577,800 \mathrm{~m}^{3}$ & $68,010,000 \mathrm{gal}$ \\
& $152,650,000 \mathrm{gal}$ & $621,100 \mathrm{~m}^{3}$ \\
Mixed low-level & $87,255 \mathrm{~kg}$ & $164,100,000 \mathrm{gal}$ \\
& $192,313 \mathrm{lb}$ & $76,846 \mathrm{~kg}$ \\
Industrial & $21,525 \mathrm{~kg}$ & $169,368 \mathrm{lb}$ \\
& $47,441 \mathrm{lb}$ & $24,423 \mathrm{~kg}$ \\
\hline
\end{tabular}

${ }^{a}$ Waste Management Operations Monthly Report for September 1992.

${ }^{b}$ Waste Management Operations Monthly Report for September 1993.

of solid TRU waste are currently being generated. Radioactive waste management operations include solid, liquid, and gaseous waste activities.

\section{Transuranic waste}

Under DOE guidance ORNL has been segregating and retrievably storing the majority of its solid alpha-contaminated waste since 1970 , pending the availability of permanent disposal. Some of these wastes, such as glove boxes and other large, bulky items, have been irretrievably buried as SC waste. The Waste Isolation Pilot Plant (WIPP), located in New Mexico, is the planned DOE disposal facility for TRU waste. Over the past several years ORNL has been developing the procedures for certifying TRU waste for disposal at WIPP and has employed the Waste Examination and Assay Facility (WEAF) for nondestructive assaying (NDA) and nondestructive examination (NDE) of stored contacthandled $(\mathrm{CH})$ TRU waste. Significant quantities of sludges contaminated with TRU radionuclides from liquid waste operations are stored at ORNL. These sludges are to be processed as remote-handled (RH) TRU waste in a proposed facility at ORNL. A number of issues, however, have recently been identified that may impact the proposed Waste Handling and Packaging Plant (WHPP) Project.

Solid TRU and mixed TRU wastes at ORNL are stored in various facilities in the north area of Solid Waste Storage Area (SWSA) 5. Sludges are stored in the Melton Valley storage tanks (MVSTs) and other active and inactive tanks in the Liquid Low-Level Waste (LLLW) System at ORNL. Because a significant fraction of ORNL TRU wastes are also mixed wastes, the Federal Facilities Compliance Agreement (FFCA) is also applicable to their management. This agreement prohibits land disposal of all untreated mixed wastes. 


\section{Solid low-level waste}

Until 1986 all SLLW, including some mixed waste (primarily lead) generated at ORNL, was disposed of on-site by shallow land burial generally in unlined trenches and auger holes. SWSA 6, which is the active LLW disposal area at ORNL, has been used for LLW disposal since 1969. Starting in 1984, the practice of shallow land disposal on the Oak Ridge Reservation (ORR) came under close scrutiny by federal and state regulators and DOE officials. Major changes in the operation of SWSA 6 were initiated in 1986 including (1) the exclusion of all mixed waste from disposal, (2) the increased use of greater confinement disposal techniques such as concrete silos and lined auger holes for disposal of CH and RH SLLW, and (3) the storage of some CH SLLW at the Oak Ridge K-25 Site. Because of the disposal practices in SWSA 6 prior to 1986, some areas in SWSA 6 are being remediated under the ORR Comprehensive Environmental Response, Compensation, and Liability Act Federal Facilities Agreement.

In December 1992 ORNL began phasing out some below-grade disposal operations at the request of the TDEC DOE Oversight Division because of concerns (1) about shallow land disposal in the trenches and landfill and (2) whether the below-grade wells would meet the long-term performance objectives of DOE Order 5820.2A. Disposal in wells was suspended in December 1992 but may be converted to retrievable storage of very high range $(>1 \mathrm{rem} / \mathrm{h})$ RH SLLW in FY 1994. The landfill was also closed for disposal of very low activity wastes in December 1992, and the unlined trenches were phased out for biological (i.e., animal) wastes in December 1992 and for all biological wastes in March 1993. Only the concrete silos continue to be used for below-grade disposal.

Current plans are to phase out all below-grade disposal in SWSA 6 by December 1993 depending on the results of the SWSA 6 radiological Performance Assessment (PA) and the revised closure schedule for Waste Area Group (WAG) 6. Beginning in January 1994, ORNL SLLW may be disposed of only in the above-grade tumulus Interim Waste Management Facility (IWMF). The IWMF began operation in FY 1992. In the early 2000s, new LLW disposal facilities being developed by the Energy Systems Waste Management Organization (ESWMO), formerly called the Central Waste Management Division, are to begin operation, and the IWMF will be closed.

DOE Order 5820.2A, Chap. III, requires that each operating SLLW disposal facility meet radiological performance objectives. A site-specific radiological PA will be completed in December 1993 for SWSA 6 and the IWMF to demonstrate compliance with these performance objectives. The current strategy for managing ORNL SLLW is to develop radionuclide concentration limits for each disposal technique at SWSA 6 and the IWMF based on the final results of the PA. This strategy is used in lieu of the Low-Level Waste Disposal Development and Demonstration (LLWDDD) Program strategy developed by Martin Marietta Energy Systems, Inc., in 1987. The LLWDDD strategy established classes of waste disposal technologies (i.e., Classes L-I, L-II, L-III, and L-IV) depending on the isotopic composition and concentrations in the waste. The LLWDDD waste classes continue to be used to refer to types of LLW storage or disposal facilities but are only a carryover from the former LLWDDD Program. In general, Class L-I refers to wastes suitable for below-grade trench disposal, Class L-Il refers to wastes requiring disposal in engineered facilities designed to isolate the waste from the environment for long time periods, and Classes L-III and L-IV refer to higher activity wastes not suitable for disposal on the ORR. The "classes of waste" system may be adopted by ORNL in the future if the ESWMO disposal facilities require this type of waste classification. 


\section{Special-case solid low-level waste}

SC SLLW does not fit into typical management strategies developed for the other major SLLW waste types, nor does it fit into a TRU waste category; therefore it requires special management and disposal strategies. Five categories of SC waste have been identified for management: (1) PA-limiting, (2) greater than Nuclear Regulatory Commission Class C, (3) uncertified or uncharacterized, (4) high-level incidental waste, and (5) DOE loan/lease material. A draft DOE integrated Spent Nuclear Fuel Program Plan was issued in July 1993 for comments. ORNL recommended that all SC waste be included under the Spent Nuclear Fuel Program to prevent leaving other SC waste as orphan waste.

Under the former LLWDDD Program, PA limitations for on-site disposal were the principal consideration for SC waste, which included Class L-III and Class L-IV waste. The segregation and storage of PA-limited wastes will begin in FY 1994 following development of radionuclide concentration limits for SWSA 6 disposal facilities. The segregation and storage of the other categories of SC waste is primarily in SWSA 5N storage wells or ORNL generator hot cells. (The hot cells are not managed by WMRAD.)

\section{Liquid low-level waste}

ORNL employs two systems for handling and processing liquids that contain radioactive constituents: the LLLW System and the Process Waste System (PWS). The LLLW System handles waste solutions with significant amounts of radioactivity including waste streams originating from hot sinks and drains in research and development (R\&D) facilities and from other sources such as TRU-processing facilities, the High Flux Isotope Reactor (HFIR), and the Process Waste Treatment Plant (PWTP). The LLLW System, which uses an evaporation system for volume reduction, processed $\sim 1.7$ million $\mathrm{L}(\sim 440,120 \mathrm{gal})$ of waste and produced 89,487 L (23,640 gal) of concentrate in FY 1993. The evaporator overhead was discharged to the PWS, and the concentrates were placed in storage in the MVSTs.

\section{Process waste}

The PWS handles all liquid aqueous waste that contains trace amounts of radioactivity, heavy metals, and organics or has the potential to be contaminated with these constituents. The process waste solutions generated by various program activities throughout ORNL are collected into central holding tanks and processed through the PWTP, which employs softening and ion exchange units to remove radionuclides. The PWTP throughput is $\sim 257$ million L/year ( 68 million gal/year). In April 1990 the Nonradiological Wastewater Treatment Plant (NRWTP) began polishing the PWTP effluent and other ORNL process waste streams prior to release to White Oak Creek (WOC). The NRWTP throughput was $\sim 621$ million L ( 164 million gal) in FY 1993. The NRWTP effluent is released to WOC through a National Pollutant Discharge Elimination System (NPDES) monitoring station. Operations for both the LLLW System and the PWS are monitored, controlled, and recorded at the Waste Operations Control Center.

\section{Gaseous waste}

The three general types of radioactive air streams at ORNL include (1) process offgas streams characterized as low-volume, potentially high-activity gaseous streams from process vessels and from systems or other sensitive areas where the concentration of 
radioactivity may be routine and highly concentrated; (2) cell ventilation (CV) air streams characterized as high-volume, low-activity gas streams from enclosed areas such as containment or confinement areas, limited-access areas, and hot cells; and (3) laboratory hoods and individual vents that provide controlled ventilation for laboratory-type operations or exhaust from vessels that are vented through appropriate pollution control devices at the source location.

Seven CV Systems with stacks are currently used for discharging CV air and process off-gas containing gaseous radioactive effluents. The basic equipment used in most of the CV Systems that discharge to major stacks includes filters, fans, and the ducts used to transport air. Radiation-monitoring instruments are connected to either the stacks or ducts entering the stacks. Where conditions dictate, charcoal absorbers or chemical scrubbers are used in the process off-gas streams to remove reactive gases such as halogens and acidic vapors prior to discharge to the CV System. For short half-life radionuclides, such as radon, holdup is used to allow decay before discharge. Noble gases are diluted with $\mathrm{CV}$ air and discharged to the stacks.

In addition to the major stacks, a number of individual vents through which small quantities of radioactive material may be discharged are used at ORNL. Located throughout the ORNL facilities, these sources are mainly vents from storage tanks and exhausts from hoods and glove boxes used for individual small-scale experiments and analytical chemistry work.

Many of the facilities for handling radioactive gas emissions have been in operation for over 20 years. Generally, the equipment that is accessible has been maintained in good working condition. Some systems have undergone significant upgrading through a line item capital project initiated in 1981. The program strategy is to identify and to implement system upgrades needed to ensure regulatory compliance and to meet DOE "as low as reasonably achievable" objectives. In addition, potential regulatory changes or new regulations are evaluated to determine if additional upgrades or new equipment will be required for future compliance.

\section{Hazardous Waste Management}

The Resource Conservation and Recovery Act (RCRA) is the primary regulatory driver for ORNL hazardous waste management operations. The state of Tennessee has been authorized by the EPA to develop and to implement laws and regulations essentially equivalent to those of RCRA. The state regulations are addressed in the Tennessee Hazardous Waste Management Rules. The Toxic Substances Control Act (TSCA) is another important driver for ORNL waste management operations. Under the TSCA, the EPA regulates the handling, management, and disposal of polychlorinated biphenyls (PCBs). At ORNL, hazardous wastes include those regulated by RCRA or the TSCA, special sanitary wastes, and other wastes identified by ORNL as representing an unacceptable hazard to personnel or to the environment if improperly managed.

\section{Solid and liquid hazardous wastes}

ORNL's R\&D activities produce a large number of diverse waste streams. All the characteristically hazardous and many of the listed hazardous wastes defined by the EPA and/or the TDEC appear on ORNL's RCRA Part A permit application. Because liquid and containerized gaseous wastes are considered "solid" wastes by the EPA and the TDEC and are subject to solid waste rules, liquid, gaseous (containerized), and solid hazardous wastes are managed similarly at ORNL. 
The focus of hazardous waste management is segregation, repackaging, and storage in preparation for shipment to commercial facilities for treatment and/or disposal. Waste tracking and documentation is a critical aspect of the ORNL management strategy. Waste treatment is provided on-site at the Acid Neutralization Facility for bulk non-nitrate acid and at the Chemical Detonation Facility for explosive wastes.

Several facilities are currently used for storage of hazardous waste at ORNL. The majority of waste is stored in 208-L (55-gal) drums in Building 7652, which has a capacity of $57,254 \mathrm{~L}(15,125 \mathrm{gal})$. Inventories of waste in the various storage facilities vary monthly, since these areas are used for staging the waste for final disposition. Additional hazardous waste storage facilities are located in the Hazardous Waste Management Area off the Health Physics Research Reactor access road at ORNL.

Two major policy developments occurred in 1991 that continue to have major impact on hazardous and mixed waste operations: the so-called "Off-Site Shipment Moratorium" and the "No Rad Added" policies. The Off-Site Shipment Moratorium was implemented by DOE on May 17, 1991, and it halted all off-site shipments of hazardous or mixed waste from ORR sites. This was followed in November 1991 with the companion policy referred to as the Performance Objective for the Certification of Non-Radioactive Waste. This policy stipulated that no waste shall be shipped to a private sector storage, treatment, and disposal facility unless it has been certified as not containing DOE-added radioactive contamination (i.e., no rad added). Compliance with these policies has placed an additional administrative and certification burden on the various waste management organizations affected by these policies. To help alleviate the storage problems created by accumulating wastes on ORR sites, the ESWMO has been evaluating the potential for off-site shipment of radioactive wastes to other DOE sites for disposal. During the spring of 1993, the Hazardous Waste Operations Group transferred $\sim 746$ flammable liquid organic waste drums to the Oak Ridge K-25 Site for storage.

\section{Gaseous hazardous waste}

Approximately 12 leaking cylinders are handled per year at ORNL. The current management strategy involves the venting of compressed gases to the atmosphere at a remote site (i.e., away from inhabited areas) off Ramsey Drive and the Melton Valley access road at ORNL.

\section{Mixed Waste Management}

Mixed waste contains both hazardous and radioactive components. Currently, the hazardous components of mixed wastes are defined and regulated under RCRA; the radioactive components, under the Atomic Energy Act. Regulation under both of these acts exists because no regulatory program focused exclusively on mixed wastes.

DOE Order 5400.3 states that "whenever any hazardous waste identified or listed in 40 CFR Pt. 261 is mixed with any source material, special nuclear material, or byproduct material, the hazardous component is subject to regulation under Subtitle C of the RCRA." A parallel strategy has been implemented for radioactively contaminated PCB wastes. These are also classified as mixed wastes.

Examples of mixed waste at ORNL are cleaning fluids and oils removed from systems operated in contaminated environments and from scintillation fluids that contain radioactive tracer elements used for chemical and biological analyses. In addition, small quantities of a wide variety of mixed wastes are generated by ORNL R\&D and operational activities. In FY 1993 ORNL generated about $24,423 \mathrm{~kg}(53,828 \mathrm{lb})$ of these types of mixed 
wastes. At present, large amounts of mixed waste are in the TRU and LLLW waste streams. The inventories of these waste streams as of December 31,1992 , are $1,139,176 \mathrm{~kg}$ $(2,278,352 \mathrm{lb})$ and $3,889,985 \mathrm{~kg}(8,575,949 \mathrm{lb})$ for TRU and LLLW respectively. The inactive tanks that are part of the LLLW System are managed by the Environmental Restoration Program.

Currently, commercial treatment is unavailable. No on-site treatment of stored mixed waste is available at this time. Until treatment methods become available, these wastes will continue to be stored on-site. Additional characterization and evaluation is needed to determine whether some of these wastes may be accepted for treatment at the TSCA Incinerator at the Oak Ridge K-25 Site.

Mixed waste storage capacity at ORNL is limited at present. Drum storage for solid and liquid mixed waste is currently provided in Buildings $7654,7507 \mathrm{~W}$, and 7823 . Bulk storage of mixed waste oils is provided by tank 7830a. Building $7507 \mathrm{~W}$ has been filled to capacity, and Building 7654 is nearing capacity. To relieve this congested condition, new mixed waste storage facilities are planned.

An effort to better characterize 850 mixed waste drums was initiated in early 1991 . The objective of this work includes (1) identification of drums that would meet the PWTP Waste Acceptance Criteria (WAC) to facilitate treatment, (2) improvement of characterization data to help identification and selection of off-site waste treatment facilities including the K-25 TSCA Incinerator, and (3) characterization of those drums that have little or no process data traceable to them in accordance with RCRA. These drums were received by WMRAD prior to 1984 and did not undergo the level of tracking and documentation currently applied to newly generated (NG) waste. This work was completed in June 1993. Sampling and analysis to achieve further characterization will be conducted on a portion of the 850 drums examined in process knowledge evaluations conducted from 1991 through 1993. Further, extensive examination and review of waste data has been ongoing in FY 1993 to support treatment technology development [see below under the land disposal restriction (LDR) FFCA].

On May 8, 1992, the RCRA LDR rule prohibiting the land disposal of all untreated mixed wastes became fully effective. This development prompted the signing of an FFCA to provide a system of schedules and milestones intended to bring ORNL into compliance with RCRA LDR. The primary deliverables for the FFCA are a Waste Treatment Plan, a Waste Treatment Strategy Plan, a Waste Minimization Plan, a Waste Storage Plan, and an Implementation Plan. Successful completion of the FFCA has become one of the highest priority activities for WMRAD for FY 1993 and beyond. Significant levels of resources are being devoted to implementation of the FFCA.

On October 6, 1992, the Federal Facilities Compliance Act (FFCAct) became law. This statute amended RCRA such that the federal government would be liable to all solid and hazardous waste regulations in the same manner as private persons and companies. This constitutes the waiver of sovereign immunity by the U.S. government allowing civil suits to be filed against it by the states and private parties. Some of the provisions of this act include a 3-year moratorium on the enforcement of mixed waste and radioactive regulations, an inventory of mixed wastes at all federal facilities, and a listing of available treatment technologies for those inventories. It is possible that this act will replace the FFCA as the mechanism for establishing compliance in mixed waste on the ORR. However, at this time both the FFCAct and the FFCA are being adhered to separately. 


\section{Industrial and Sanitary Waste Management}

Industrial and sanitary wastes at ORNL include both solid and liquid wastes. The state of Tennessee regulates these waste streams at ORNL via the Tennessee Solid Waste Disposal Act and ORNL's NPDES permit.

\section{Solid industrial and sanitary wastes}

Solid sanitary wastes include filter cake from the Coal Yard Runoff Treatment Facility, general refuse collected in trash cans and dumpsters, and construction debris. The volume of general refuse is estimated to be $\sim 28.2 \mathrm{~m}^{3} /$ day $\left(\sim 37 \mathrm{yd}^{3}\right)$. Runoff from the Coal Yard Storage Area, plus wastewater from the sulfuric acid diked area, Steam Plant boiler blowdown, and water softener regenerate, are dewatered producing $263 \mathrm{t} /$ year (290 tons/year) of filter cake.

Other than the equipment used for the compaction of general refuse, no treatment or storage facilities currently exist at ORNL for handling solid sanitary waste. The majority of ORNL sanitary waste is now disposed of in the Y-12 Sanitary Landfill II, which is located on Chestnut Ridge south of the Oak Ridge Y-12 Plant and $\sim 9.7 \mathrm{~km}(\sim 6$ miles) east of ORNL. Approximately 300 to $400 \mathrm{~m}^{3}\left(\sim 400\right.$ to $\left.500 \mathrm{yd}^{3}\right)$ of soil, rock, and concrete mixtures are deposited at the Y-12 SLF II dirt fill area annually. The SLF II is scheduled to be closed when the new Industrial Landfill $\mathrm{V}$ is opened early in 1994. ORNL has established recycling programs for white paper, cardboard, toner cartridges, and aluminum beverage containers to reduce the amount of solid sanitary waste disposed in the Y-12 SLF II.

\section{Liquid industrial and sanitary wastes}

Liquid sanitary waste includes nonradioactive waste streams that are discharged, either directly or following treatment, to WOC. ORNL sources include Sewage Treatment Plant effluent from Bethel and Melton Valleys, area runoff of rainwater, and CYRTF effluent.

Approximately $757,000 \mathrm{~L} / \mathrm{d}\left(\sim 2.0 \times 10^{5} \mathrm{gal} / \mathrm{d}\right)$ of ORNL sanitary sewage is treated by an aerobic digestion process. The ORNL Sewage Treatment Plant, operated under ORNL's NPDES permit, produces a sludge that is dewatered on sludge-drying beds. Influent to the Sewage Treatment Plant can occasionally contain radioactivity owing to contamination from the laundry. Options are under review including routine laundry discharge to the LLLW System as needed per routine sampling.

Most of the Storm Sewer System is constructed of reinforced concrete piping and contains catch basins that drain areas in Bethel and Melton Valleys and drain to WOC.

\section{Decommissioning of Radioactively Contaminated Facilities}

ORNL has many radioactively contaminated facilities that are awaiting decontamination and decommissioning (D\&D) and must be managed in a manner that protects the public health and safety and the environment. Also, new and existing facilities will eventually require $D \& D$ some time in the future. In general, D\&D activities are concerned with facilities such as reactors, hot cells, processing plants, some LLLW storage tanks, and other structures whose demolition is likely to result in health and safety and environmental impacts if sufficient controls are not exercised.

ORNL waste management activities associated with decommissioning of radioactively contaminated facilities can be divided into four areas: operational facilities, 
inactive or surplus facilities, future facilities planning, and D\&D activities. Radioactively contaminated facilities that are currently operational are the responsibility of the line management organization operating the facility. Funding for the operation and maintenance of these facilities is provided by various program organizations within DOE.

ORNL, which has been an operational site since the 1940s, has approximately 70 surplus facilities. The overall strategy for the management of these inactive facilities is (1) to maintain and to monitor these facilities to ensure that the radioactivity is contained in a manner that limits exposure to personnel and the general public and protects the environment from potential hazards and (2) to plan for D\&D of these facilities.

The goals of D\&D are (1) to decontaminate facilities to the extent necessary for compliance with approved health and safety standards and (2) to decommission facilities in accordance with the requirements set forth in an approved environmental compliance plan. Several ORNL facilities have undergone D\&D over the past 5 to 10 years, and several D\&D projects are currently in progress. Planning for D\&D will be an integral part of the design of all future facilities at ORNL.

\section{MAJOR ACCOMPLISHMENTS AND SIGNIFICANT REGULATORY AND ENVIRONMENTAL ISSUES FOR FISCAL YEAR 1993}

In FY 1993 WMRAD participated in, conducted, or supervised a wide diversity of environmental and waste management activities. The major operational activities included the storage, treatment, and handling of $\sim 830$ million $L(\sim 220$ million gal) of liquid waste regulated under the Clean Water Act and $14,000 \mathrm{~m}^{3}\left(500,000 \mathrm{ft}^{3}\right)$ of solid waste covered under RCRA and/or DOE Order 5820.2A. Of the solid radioactive waste, $1484 \mathrm{~m}^{3}$ $\left(53,000 \mathrm{ft}^{3}\right)$ was nonretrievably disposed of in accordance with DOE Order 5820.2A. The remaining activities can generally be characterized as operational support, program and project management, waste reduction and minimization, and other environmental activities.

Several reporting mechanisms are used by WMRAD to communicate accomplishments, status, and concerns to DOE, the ESWMO, and ORNL management. The information contained in these reports is usually in bulletized, discrete form. The most relevant and significant of the items reported by WMRAD in FY 1993 follow:

\section{Transuranic Waste}

- Completed and issued the Nuclear Fuel Services (NFS) Waste Parameter Verification Program.

- Finalized and issued the Waste Acceptance Criteria (WAC) for NFS wastes (WMRAWMPC-106).

- In support of WHPP development, began preparing the pilot-scale Wiped Film Evaporator for testing of simulated MVST liquids and sludges.

- Performed the annual program audit of the ORNL TRU Certification Program as required in the TRU Quality Assurance Plan. Activities covered included seven generator programs, the WMRAD Document Management Center, training, the WMRAD Certification Group, and WEAF.

- Evaluated TRU waste projections from the Isotopes Shutdown Program, Environmental Restoration Program, and the Decommissioning and Decontamination Program. These will be combined with projections from off-site generators and active ORNL TRU generators to assess storage capacity requirements. 
- Developed a response to DOE-HQ status of site handling of TRU $>10 \mathrm{nCi} / \mathrm{g}$ and $<100 \mathrm{nCi} / \mathrm{g}$.

- Started up pilot-scale Wiped Film Evaporator testing using surrogate MVST supernatant.

- Completed the first pilot test phase for the Wiped Film Evaporator in support of WHPP design. Surrogate MVST supernatant was tested to evaluate operating characteristics of the Wiped Film Evaporator and to determine the maximum volume reduction obtainable for MVST supernatant. Internal inspection of the Wiped Film Evaporator revealed significant damage of rotor blades and the blade mounting pins after testing of simulated MVST s"'pernatant. New blade and pin materials are being evaluated for replacements.

- Received 140 additional CH TRU waste drums from NFS.

\section{Solid Waste}

- Completed and obtained approval for the Comprehensive Work Plans, Site Safety and Health Plans, Quality Assurance Project Plans, and Waste Management Plans for the RCRA closures of Buildings 7555, 7659B, and 7075.

- Submitted Phase IA safety documentation for six moderate/high hazard hazardous/mixed waste facilities and two radioactive solid waste facilities. The Phase IA safety documentation for the two radioactive solid waste facilities was approved by DOE-ORO.

- Completed loading IWMF pad I, which contains 324 vaults. A total of 131 vaults were placed on pad I in FY 1993.

- Initiated operations on IWMF pad II. A total of 132 vaults were placed on pad II in FY 1993.

- Completed evaluation of IWMF expansion. Present location will accommodate up to 12 pads instead of 6 that were in the original plan.

- Initiated RCRA closure of Buildings 7826 and 7834. A total of 4 of the 48 cells were emptied of CH TRU mixed waste.

- Submitted information to DOE-ORO documenting the retirement of Safety Analysis Reports and Operational Safety Reports approved in 1983 and replacement with current Safety Analysis Report Update Program safety documentation.

- Initiated efforts to ship SLLW off-site for volume reduction by incineration or supercompaction. Shipped a total of $25 \mathrm{~m}^{3}\left(864 \mathrm{ft}^{3}\right)$ in FY 1993.

- Developed SLLW storage/disposal options as a result of changes in SWSA 6 operations.

- Received and initiated NDA and NDE on 132 NFS CH TRU waste drums.

- Upgraded Gamma Analysis System (Gamma Assay System Passive). Incorporated ability to measure uranium and plutonium isotopics.

- Successfully demonstrated a technique for the examination of HFIR shrouds. The technique included the digitization of box real time radiography video output for measuring the thickness of cadmium and neutron-capture gamma ray analysis for cadmium.

- Installed four portable storage structures to provide storage space for $\sim 2500$ SLLW drums.

- Developed uncertainty estimates for the SWSA 6 inventory to be used by PA teams, developed screening criteria, completed source term and surface water modeling, and began the groundwater modeling and uncertainty analysis.

\section{Liquid Low-Level Waste}

- Completed the Acoustic Emission Leak-Testing Feasibility Study for the active tank system. 
- Completed a successful full-scale in-cell demonstration of a resorcinol/formaldehydebased ion exchange resin for removal of ${ }^{137} \mathrm{Cs}$ from a highly alkaline waste solution. Cesium $(1250 \mathrm{Ci})$ was removed by the resin. The resin was then successfully regenerated using a hydrochloric acid solution. Work was performed by the Radiochemical Engineering Development Center (REDC).

- Completed the 1993 LLLW generator survey and updated the database with the new information.

- Completed the first phase of pilot testing of treatment methods for simulated NG LLLW. Strontium removal by coprecipitation with stable strontium chloride and cesium removal with potassium cobalt methods performed well. Solid and liquid separation was shown to be very important in the process.

- Completed a study for removal of ${ }^{106} \mathrm{Ru}$ from simulated NG LLLW by an electrochemical ion exchange process. The process was moderately successful for removal of the nitrosyl form of ruthenium. (The study was conducted by Bradtec-U.S., Inc.)

- Completed the test program for removal of strontium from simulated NG LLLW using crown ether-based materials. Results were promising: decontamination factors $>500$ were achieved. (The program was administered by IBC Advanced Technologies, Inc.)

- Completed the assessment of options for removal of accumulated sludges from the LLLW evaporator service tank, W-22. The report recommends additional sludge characterization studies, preparations for installation of an alternate evaporator feed line, and simulated testing of mechanical sluicing methods using existing pilot test systems and computer modeling.

- Continued development of treatment methods for NG LLLW and MVST including the use of (1) potassium cobalt hexacyanoferrate for cesium removal and (2) sodium titanate for strontium removal.

- Continued development studies for pretreatment of nonprogrammatic dilute LLLW for potential diversion to the Process Waste System. These studies included developing methods for removal of trace quantities of ${ }^{60} \mathrm{Co},{ }^{99} \mathrm{Tc}$, and TRU contaminants.

- Continued development of source treatment methods for the REDC including (1) smallscale hot cell testing of a resorcinol-formaldehyde resin for removal of cesium from a highly alkaline waste, (2) testing or inorganic sorbents for removal of cesium and ruthenium from an acidic waste, and (3) sampling and characterization studies for REDC combined waste in tank F-126.

- Continued development of treatment methods for NG LLLW and MVST supernatants including (1) a study of solid/liquid separation after the use of potassium cobalt hexacyanoferrate for cesium removal, (2) a study of an improved method for removing ${ }^{90} \mathrm{Sr}$ by using coprecipitation with stable strontium chloride instead of sodium titanate sorption, and (3) a subcontract award to Bradtec-U.S., Inc., to test an electrochemical ion exchange process for removing ${ }^{106} \mathrm{Ru}$ from simulated NG LLLW.

- Completed 1 year of operation for the MVST In-Tank-Evaporation Project. The results exceeded expectations by achieving an operational availability of $92 \%$ and evaporating a total of 77,222 L (20,400 gal) of excess water from the MVST supernatants.

- Began preparing for pilot-scale testing of new treatment methods for NG LLLW using test systems at the WTTF.

- Awarded a subcontract to IBC Advanced Technologies, Inc., for testing crown ether-based materials for removal of ${ }^{90} \mathrm{Sr}$ and ${ }^{106} \mathrm{Ru}$ from simulated NG LLLW.

- Completed the WC-10 pump pit upgrade.

- Conducted leak tests on tanks WC-2, WC-3, and WC-19 using the Operator Diagnostic Unit. 
- Installed a replacement W-12 transfer line and provided justification for return to service as a Category $\mathrm{C}$ tank.

- Repaired the WC-10 Tank Farm discharge line, briefed regulators, submitted 30-day report, and received regulator approval for return to service.

\section{Mixed Waste}

- Achieved compliance with aisle space regulations in hazardous and mixed waste storage facilities. The schedule for shipments to the Oak Ridge K-25 Site was accelerated, and container storage configurations were revised.

- Completed replacement of tent structure covering the $7507 \mathrm{~W}$ pad. The facility contains 2320 208-L (55-gal) mixed waste drums.

- Completed the four remaining Tiger Team Action Items relating to operations in $7507 \mathrm{~W}$. The specific items addressed included appropriate waste segregation, waste secondary containment, facility waste location maps, and additional fire protection.

- Continued preparations for shipment of hazardous/mixed waste to the Oak Ridge K-25 Site for storage. In FY 1993 a total of 746 drums [121,109 kg $(267,000 \mathrm{lb})]$ of hazardous/mixed waste were shipped to the Oak Ridge K-25 Site.

\section{Process Waste System Upgrades}

- Began cold-testing of a new zeolite test system installed in the Wastewater Treatment Test Facility (WTTF).

- Began preparing for bench-scale studies to determine zeolite capacity for heavy metals removal.

- Continued development studies for process wastewater that included (1) startup of new zeolite test systems at the WTTF using actual process wastewater and (2) mathematical modeling of multicomponent ion exchange for the zeolite/process wastewater to predict zeolite loading capacity and mass transfer zone length.

- Began procurement process for leasing a commercial ion exchange system for demonstration of process wastewater treatment using zeolites.

- Completed an independent analysis (by AquAeTer, Inc.) of the ORNL PWS to recommend design changes for meeting new and more stringent NPDES permit limits. Recommended for further evaluation were (1) improved methods for removal of heavy metals at the NRWTP and (2) alternate discharge points where a larger receiving stream would raise the value of the end-of-pipe discharge limits.

- Leased a commercial ion exchange system and placed the system equipment in the containment area surrounding the Bethel Valley storage tanks. The system will be used to demonstrate the use of zeolite for removal of strontium and cesium from process wastewater. System hookup is in progress.

- Developed a simple mathematical model for calculating strontium breakthrough for zeolite using the Rosen long-bed solution of the partial differential equations for fixedbed column operations. The model successfully represented the data and predicted the mass transfer zone lengths from five experimental zeolite tests.

- Completed a database containing all the analytical data from Process Waste System sampling activities for the past 3 years. A user manual for operating the database is being prepared.

- Initiated the readiness review process for the Evaporator 2A-2 Replacement Project and the WC-10 Pump Pit Maintenance Modification Project.

- Emptied inactive LLLW tank WC-17 and removed sludges.

- Completed specifications for a new spare evaporator. 
- Completed replacement of six NRWTP feed pumps.

- Obtained approval for the installation and operation of a carbon dioxide system that controls the $\mathrm{pH}$ of IWMF water runoff to below 9.0. This eliminates the need for collecting and trucking IWMF pad water runoff to the Process Waste Treatment System.

- Redesigned the in-line mixer system at the PWTP and installed a new system.

- Replaced instrumentation to the PWTP Processing System.

\section{Gaseous Waste}

- Conducted a survey and evaluation of the need to continue operation of a caustic venturi scrubber on the Off-Gas System.

- Replaced the Motor Control Center for the 3092 Central Off-Gas System.

\section{Industrial and Sanitary Wastes}

- Prepared revision of the Industrial Waste Control Plan and continued monitoring of program implementation.

- Completed production of a training video as part of the industrial waste control activity.

\section{Waste Reduction}

- Identified a commercial outlet for the recycle of telephone books and implemented a phone book recycling initiative that was conducted in February.

- Prepared a summary of the recycling effort for the calendar year to date (through September): paper, 100,743 kg (222,100 lb); cardboard, 100,452 kg (221,460 lb); and aluminum $2,694 \mathrm{~kg}(5,940 \mathrm{lb})$.

- Modified the REDC Off-Gas Scrubber System operation (i.e., from using a 5-m KOH solution to a $2.2-m \mathrm{NaOH}$ solution). This modification not only further reduces the amount of LLLW concentrate produced at the REDC but will also aid in future REDC waste treatment by eliminating potassium ions that would otherwise interfere with processes being developed for removal of ${ }^{137} \mathrm{Cs}$ from the waste.

- Began routinely reviewing National Environmental Policy Act (NEPA) documentation for waste minimization aspects.

- Initiated efforts to implement a photographic waste silver recovery program.

- Arranged for shipment off-site and recycle of 125 laser printer toner cartridges.

- Completed and issued a revision of the ORNL Waste Reduction Program Plan, which addresses FFCA requirements, Tennessee/U.S. DOE Oversight Agreement requirements, and DOE waste minimization crosscut.

- Established interface with the AVID Custodial Evaluation Committee to include in the next AVID agreement products made from recycled material that have lower toxicity and that produce less waste.

- Initiated work with HFIR to evaluate recycling of lead shielding [9,979 $\mathrm{kg}(22,000 \mathrm{lb})]$ associated with removal/replacement of a leaking prefilter tank.

- Identified users (through Swap Shop) for $416 \mathrm{~L}$ (110 gal) of ethanol, one drum of Freon, and $20 \mathrm{~L}(5 \mathrm{gal})$ of $\mathrm{H}_{2} \mathrm{SO}_{4}$, which eliminated the handling of these materials as hazardous waste.

- Continued recycling efforts during FY 1993 at ORNL. The results are as follows: paper, $172,365 \mathrm{~kg}(380,600 \mathrm{lb})$; cardboard, $157,306 \mathrm{~kg}(346,800 \mathrm{lb})$; aluminum, 3,719 kg $(8,200 \mathrm{lb})$; phone books, $3,538 \mathrm{~kg}(7,800 \mathrm{lb})$; and toner cartridges, 352 total. 
- Initiated an effort to ship $158,757 \mathrm{~kg}(350,000 \mathrm{lb})$ of salvaged scrap metal to Scientific Ecology Group, Inc., an off-site subcontractor, for processing. The first shipment of $9,457 \mathrm{~kg}(20,850 \mathrm{lb})$ was made August 6.

- Shipped initial loads of fly ash from the ORNL Steam Plant to a cement-manufacturing plant. Diverting the coal ash will reduce ORNL's disposal of sanitary waste by an estimated 10 to $15 \%$ annually.

- Presented elements of the Waste Reduction Program to the TDEC during their June audit of the Hazardous Waste Program; no deficiencies were identified.

\section{Certification}

- Presented an overview of ORNL SLLW certification/characterization at a DOE PA Task Team workshop.

- Began delivery of a training module specifically for generator certification officials.

- Developed a draft Hazardous/Mixed Waste Certification Program Plan that is being reviewed internally by WMRAD.

- Developed a revision to SWSA 6 WAC to reflect Tennessee Oversight Agreement-driven changes to solid waste operations activity.

- Developed an assessment of the number of WAC needed to encompass the storage, treatment, and disposal facilities at ORNL.

- Continued to support ESWMO activity by participation in the NDA and NDE Performance Improvement Process Team evaluating characterization and verification facilities.

- Issued WAC for RH SLLW storage.

- Completed surveillances of all ORNL SLLW generators.

- Developed and initiated use of a uniform Request for Disposal. Completed a pilot program with selected ORNL generators. Conducting generator training on using new Request for Disposal. The new form is scheduled to be in full use by the end of 1993.

- Developed draft Hazardous and Mixed Waste Certification Program Plans and issued these for review.

- Submitted WAC for TRU waste received at ORNL from off-site.

\section{Strategic Planning and Operations Support}

- Initiated a Self-Assessment of the status of implementation of DOE Order 5820.2A.

- Continued development of the ORNL Waste Management Long-Range Plan in support of previously developed strategic objectives.

- Supported ESWMO activity to develop the strategy for future management of LLW on the ORR.

- Continued support of ESWMO deliverables and initiatives relating to the LDR FFCA and the FFCAct.

- Issued a draft needs-driven assessment of ORNL TRU waste management strategy for review and comment in response to questions from the DOE-HQ Task Force on WHPP.

- Completed the storage and disposal strategy for ORNL SLLW.

\section{Capital Projects}

- Completed construction on two FY 1989 general plant projects: Manhole Monitors Process Waste and Hydraulic Head Measuring Stations.

- Made significant progress on construction of the Transported Waste-Receiving Facility. 
- Completed decontamination at the Monitoring and Control Station. Construction is nearing completion. Construction of external piping associated with this station is complete.

- Completed construction associated with LLLW piping for laboratories and hot cells 1 through 4 in Building 2026.

- Obtained approval of NEPA documentation-DOE-ORO milestone was satisfied.

- Initiated long-lead procurement-DOE-HQ milestone was satisfied. Completed four equipment specifications.

- Received DOE-ORO approval of the Systems Requirements Document for the Process Waste Treatment Facility Project.

- Transmitted four preliminary proposals to DOE for approval. Issued six Design Review Packages. Completed two designs.

- Initiated construction on the NFS Storage Facility and the WEAF upgrade.

\section{PLANNED ACTIVITIES}

Activities in this category include long-range and strategic planning, operational continuity planning and support, and NG waste evaluation and pilot plant testing. The more significant activities identified in the FY 1994 Current Year Work Plan follow:

\section{Liquid Low-Level Waste}

- Provide regulatory compliant operation of the LLLW Collection, Transfer, Evaporator, and Storage System.

- Complete Phase II of the cathodic protection upgrade and initiate Phase III.

- Update the LLLW database per Chap. III of DOE Order 5820.2A.

\section{Transuranic Waste}

- Complete RCRA closures of Buildings 7826 and 7834.

- Complete examination of CH TRU waste drums received from NFS.

- Evaluate use of the in-cell drum compactor at the REDC for RH TRU waste.

- Evaluate RH TRU waste drum loadout at the REDC.

- Prepare an on-site CH TRU waste drum repackaging action plan.

- Continue development of a Request for Quotation for remote examination and assaying of RH TRU waste.

- Continue development on the Wiped Film Evaporator for treatment of tank sludge.

- Continue development work on a microwave melter for treatment of tank sludge.

- Prepare a report on TRU waste inventory at ORNL.

- Prepare a report on contingency planning for ORNL TRU waste storage facilities.

\section{Mixed Waste}

- Continue shipments of hazardous/mixed waste to the Oak Ridge K-25 Site for storage.

- Continue to provide DOE input required for approval to resume off-site shipments of hazardous waste to commercial treatment, storage, and disposal facilities.

- Expedite construction of hazardous/mixed waste storage facilities. 


\section{Solid Low-Level Waste}

- Continue shipping SLLW off-site for volume reduction by incineration or supercompaction.

- Complete construction of IWMF pads III and IV. Initiate operations on IWMF pad III.

- Complete an upgrade of WEAF (Building 7824).

- Complete disposal of wastes from WAGs 11 and 13 to support environmental restoration efforts.

\section{Industrial and Sanitary Wastes}

- Complete lining of the existing sewer collection grid and sealing of manholes.

- Complete revitalization of sludge-drying beds.

- Complete construction of the suspect waste accumulation pad.

\section{Gaseous Waste}

- Conduct an evaluation of long-term operation of all WMRAD Gaseous Waste Systems.

- Develop a Memorandum of Understanding designating facility ownership and operations and maintenance responsibility among divisions at ORNL.

\section{Planning}

- Issue the ORNL Waste Management Long-Range Plan and support the FFCA Waste Storage Plan, the Waste Treatment Plan, and the Waste Treatment Strategic Plan.

- Revise the ORNL LLLW and TRU Waste Strategic Plans.

\section{General Plant Projects}

- Continue to identify and to develop environmental projects (Environmental Projects Section). This activity will be performed in accordance with long-range strategies for waste management within ORNL.

\section{Line Item Support}

- Complete the Detailed Design for the upgrade to the PWTP.

- Prepare a Conceptual Design Report for the PWTF.

\section{Federal Facilities Agreement}

- Complete construction of Building 3525 (FFA LLW GPP).

- Complete construction of Building 3019A (FFA compliance GPP).

- Submit to the EPA/TDEC/DOE written design demonstrations showing that existing LLLW lines with secondary containment meet, or can be retrofitted to meet, FFA standards. 


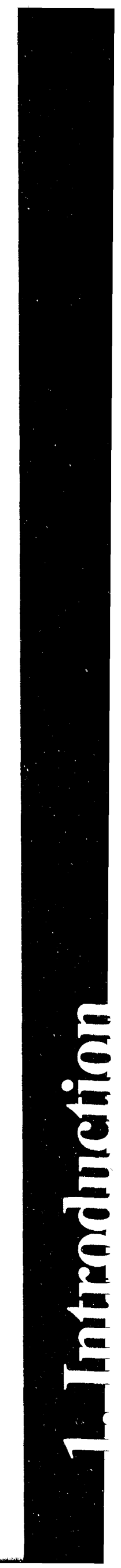




\section{INTRODUCTION}

Waste management requirements at Oak Ridge National Laboratory (ORNL) are imposed by federal and state regulations as well as Executive and U.S. Department of Energy (DOE) orders. The Atomic Energy Act of 1954 as amended (AEA) and the Resource Conservation and Recovery Act of 1976 as amended (RCRA) are the primary driving forces behind their implementation. The AEA regulates research and development activities related to atomic energy and provides for the safe processing and management of source, special nuclear, and by-product materials. Through RCRA, the U.S. Environmental Protection Agency (EPA) is given the responsibility for a nationwide program that regulates most aspects of hazardous waste management. The state of Tennessee has been authorized to administer the hazardous waste management program. The EPA also regulates the handling of polychlorinated biphenyls (PCBs) under the Toxic Substances Control Act (TSCA).

DOE Order $5820.2 \mathrm{~A}$, the principal regulation that governs management of radioactive waste at ORNL, establishes requirements to ensure that all DOE operations involving management of radioactive waste, waste by-products, and surplus facilities are conducted in a manner that will ensure protection of public health and safety in accordance with DOE Orders 5480.1B and 5400.5. DOE Order 5820.2A has four major subsections that address specific procedures and requirements related to decontamination and decommissioning (D\&D) of surplus facilities. Several other DOE orders referred to in DOE Order 5820.2A have supplemental and related requirements. This plan complies with DOE Order 5820.2A, Chap. VI, and provides a comprehensive description of current ORNL waste management activities and strategies.

\subsection{OBJECTIVES}

Waste management operations are activities that minimize, store, treat, and dispose of all radioactive, hazardous, mixed, and conventional wastes generated as a result of (1) operations at active facilities and (2) D\&D and environmental restoration activities at inactive facilities. These operations are based on a series of waste management objectives. The objectives of the ORNL Waste Management Program are:

- to manage the storage, treatment, and disposal of solid, liquid, and gaseous wastes in a timely and cost-effective manner that ensures the health and safety of the on-site personnel and the protection of the public and the environment;

- to ensure that the generation of all wastes is minimized to the extent reasonably achievable; and

- to ensure that the storage, treatment, transportation, and/or disposal of all wastes meet or exceed all applicable federal, state, and local environmental, safety, and health regulatory requirements.

This plan describes how the ORNL Waste Management Program is conducted, identifies which waste management facilities are being used to manage wastes, indicates what forces are acting to change current waste management systems, discusses what activities are planned for FY 1994, and relates how all these activities are documented. 


\subsection{PURPOSE}

DOE Order $5820.2 \mathrm{~A}$ requires that ORNL submit to the DOE Oak Ridge Operations Office (DOE-ORO) an annual report outlining its waste management activities for the minimization, storage, treatment, and disposal of waste. In fulfillment of this requirement, this plan also provides a ready reference of the ORNL Waste Management Program for internal and external use.

\subsection{SCOPE}

Addressed in this plan are all applicable requirements of DOE Order 5820.2A and other applicable DOE orders pertaining to waste management activities for low-level radioactive, transuranic (TRU), hazardous, and mixed wastes. Although not specifically required by DOE Order $5820.2 \mathrm{~A}$, this plan also addresses special case (SC), industrial, and sanitary wastes. ORNL does not generate high-level waste but does store a small quantity as SC wastes. ORNL generates small volumes of waste containing naturally occurring and accelerator-produced radioactive material (NARM). NARM wastes at ORNL are managed as low-level waste (LLW) in accordance with DOE Order 5820.2A.

This plan is organized in nine primary sections and has three supporting appendixes. The first two sections provide basic information about the ORNL site and the principal organizations at ORNL and DOE-ORO involved in waste management activities. The remaining sections address the management of the various types of wastes (i.e., radioactive, hazardous, mixed, industrial, and sanitary), provide an overview of the decommissioning of radioactively contaminated facilities, and discuss environmertal monitoring and waste management support activities at ORNL. Each section provides an overall summary of the waste categorization, a generic description of the characteristics of the wastes, the status of current and future plans for storage, treatment, and disposal of the wastes, and the compliance status and information regarding the support functions employed for each waste category. Appendix A provides an update to the original implementation summary since issuing the Oak Ridge National Laboratory Implementation Plan for DOE Order 5820.2A. Appendix B provides an updated listing of principal ORNL waste management documents generated since issuing the implementation plan. Appendix $\mathrm{C}$ lists the ORNL storage, treatment, and disposal facilities, along with the status of each, and includes information on wastes in temporary staging as weil as those in long-term storage modes

\subsection{REGULATORY REQUIREMENTS}

\subsubsection{Federal and State Regulations}

Operations programs must comply with the federal and state statutes and regulations, the AEA, and DOE orders. The major federal and state statutes applicable to waste management operations are summarized in the following paragraphs.

RCRA, as amended by the Hazardous and Solid Waste Amendments of 1984 (HSWA), regulates the activities associated with hazardous waste management. Its primary objective is to protect human health and the environment; its secondary objective, to conserve valuable material and energy resources. RCRA requires cradle-to-grave tracking of hazardous waste. Those hazardous waste disposal sites that were closed or abandoned before November 19, 1980 (effective date of RCRA regulations) are regulated under the 
Comprehensive Environmental Response, Compensation, and Liability Act of 1980 (CERCLA).

Persons (iricluding a federal facility) who generate, transport, treat, store, or dispose of RCRA hazardous waste, as well as persons who produce, burn, distribute, or market any hazardous waste-derived fuels or store regulated substances in underground tanks, must comply with RCRA by notifying the EPA or authorized states of their activities. As amended by HSWA, RCRA Sect. 3004(u) requires corrective actions for releases of hazardous constituents. RCRA Sect. 3004(v) mandates off-site corrective actions. The RCRA provisions for corrective actions overlap to some degree with CERCLA provisions-creating the need for coordination of RCRA and CERCLA activities.

The state of Tennessee is authorized (1) to administer its own RCRA program in lieu of the federal program (new RCRA regulations that become effective after the authorization date must be adhered to pending issuance of corresponding state regulations) and (2) to regulate mixtures of hazardous and radioactive wastes. The Tennessee Hazardous Waste Management Act and its implementing regulations are administered by the Tennessee Department of Environment and Conservation (TDEC), Division of Solid Waste Management. EPA Region IV administers the federal RCRA program including certain ${ }^{*}$ HWSA provisions that have been enacted by the TDEC.

TSCA regulates, among other things, the use and disposal of materials containing more than $50 \mathrm{ppm}$ of PCBs. These regulations apply to Waste Management Operations projects involving PCBs. Martin Marietta Energy Systems, Inc., policy is to regulate the storage and disposal of materials containing greater than 2 ppm of PCBs.

CERCLA, as amended by the Superfund Amendments and Reauthorization Act of 1986 (SARA), provides a federal mechanism to respond to the hazards posed by abandoned disposal sites and federal authority to respond to current uncontrolled releases of hazardous and radioactive (since May 1989) substances from a vessel (including transportation vehicles) or from any onshore or offshore facilities. The act imposes strict liability on a broad class of potentially responsible parties and establishes the funding (the "Superfund") that enables the government either to order the responsible parties to clean up the spill or to seek reimbursement from the responsible parties after the government has completed cleanup.

CERCLA also imposes reporting requirements on owners and operators of currently operating vessels and facilities. In general, any releases of a reportable quantity of "hazardous substances" must be reported, and the responsible party must clean it up. A "hazardous substance" is anything included on a "list of lists" compiled by referring to the four major environmental statutes including the Clean Air Act (CAA), the Clean Water Act (CWA), RCRA, and TSCA. As a result of the incorporation of the CAA into CERCLA, CERCLA regulates releases of radioactive source, special nuclear, or by-product material. The EPA is authorized to expand the CERCLA list by adding compounds or mixtures that, when released into the environment, may present substantial danger to public health or welfare or the environment.

Section 105 of CERCLA states that the government's cleanup activity must be conducted in accordance with the National Contingency Plan (NCP). The NCP establishes a blueprint for cleaning up releases to the water, land, or air and assigns response authority to federal and state governments and private parties. The NCP details response procedures including both immediate removal and long-term remedial actions. Section 105 also authorizes the EPA to designate sites for inclusion of sites requiring remedial action on the National Priorities List (NPL).

SARA amended CERCLA by inter alia (adding provisions specifically aimed at federal facilities) and by increasing EPA enforcement authority. As amended by SARA, 
CERCLA provides the framework for determining cleanup standards, schedules, and evaluation of remedies.

The Oak Ridge Reservation (ORR) was placed on the NPL December 21, 1989. The Federal Facilities Agreement (FFA) between EPA Region IV, the TDEC, and DOE requires ORR cleanups to be conducted in compliance with both RCRA and CERCLA/SARA. The FFA, which became effective on January 1,1992 , is intended to satisfy the requirements for an interagency agreement under Sect. 120 of CERCLA. The agreement establishes a procedural framework and schedule for developing, implementing, and monitoring appropriate response actions at the site in accordance with CERCLA, the NCP, the National Environmental Policy Act of 1970 (NEPA), and Tennessee law. The agreement contains provisions for coordinating response actions under CERCLA, RCRA, and applicable state laws. Specifically, the agreement establishes requirements for performing Remedial Investigation/Feasibility Studies and identifies the nature, objective, and schedule of response actions to be taken at the site. The agreement provides the basis for the creation of operable units and the implementation of final remediation actions. The agreement also establishes requirements for underground liquid low-level waste (LLLW) tank systems to ensure structural integrity, containment and detection of releases, and source control for LLLW tank systems pending final remedial action at the site.

Effective May 13, 1991, DOE entered into an agreement with the state of Tennessee regarding DOE's provision of financial and technical support for state oversight activities. The Tennessee/U.S. DOE Oversight Agreement (TOA) applies to TDEC participation in the FFA for environmental restoration of the ORR, oversight, monitoring, access, and emergency response initiatives to ensure compliance with applicable environmental laws and regulations. ORNL is obligated to a number of action items including a source reduction/zero discharge study, an air emissions inventory, waste and residue characterization, and others. Through this agreement the state of Tennessee has become a major stockholder in future operations at all ORR sites, including ORNL. Strategic planning, waste operations, and environmental, safety, and health activities will all receive significant input from the State as they assume their role under the TOA.

Effective June 12, 1992, DOE entered into a Federal Facilities Compliance Agreement (FFCA) with the EPA to ensure compliance by DOE with land disposal restrictions under RCRA. The FFCA became necessary because many of the radioactive mixed wastes (mixed wastes) generated by DOE sites (including ORNL) had no available treatment capacity, resulting in a noncompliance situation. The FFCA dictates the steps required to bring ORR facilities into compliance with respect to the management of mixed wastes.

NEPA requires every federal agency to address publicly (prior to initiation) the environmental impact of major federal actions that may significantly affect the environment. These concerns are addressed in documents such as Environmental Assessments or Environmental Impact Statements, which are made available to the public and are circulated to other interested agencies. Secretary of Energy Notice 15-90 provides guidance for developing NEPA documentation. DOE Notice 5400.4 establishes DOE policy on integrating NEPA and CERCLA processes for Environmental Restoration Program projects. NEPA implementation procedures to be used by DOE were promulgated in the Federal Register on April 24, 1992.

The CAA is a comprehensive and complex federal statute designed to prevent and to control air pollution from stationary and mobile sources. The CAA authorizes the EPA to establish national standards for air quality that must be met by the states through compliance with EPA-approved state implementation plans. These plans are also required to contain standards for preventing significant deterioration of air quality in areas where the ambient 
standards are already being met. Permits are required for specific air emissions. CAA requirements may also become Applicable or Relevant and Appropriate Requirements (ARARs) for CERCLA cleanups. Radionuclides are also regulated under the CAA and 40 CFR Pt. 61, Subpart H.

Air emissions from ORR facilities are managed in accordance with DOE Orders $5400.1,5400.5,5480.1 \mathrm{~A}, 5480.1 \mathrm{~B}, 5480.4$, and 5820.2A and guidelines of the CAA as regulated by the TDEC Division of Air Pollution Control. The TDEC has the primary responsibility for ensuring compliance with the CAA within the state of Tennessce and for protecting and maintaining Tennessee ambient air quality standards pursuant to the Tennessee Air Quality Control Act. The TDEC's Division of Air Quality administers the air permits program.

In May 1992 DOE and the EPA entered into an FFCA to achieve compliance in all CAA issues at the ORR. This agreement committed ORNL to a number of actions including monthly reporting, air emission inventories, quality assurance plans, and system upgrades.

The CWA sets standards for, and regulates discharges into, surface waters and sets pretreatment standards for discharges into publicly owned treatment works. Facilities, like ORNL, that directly discharge wastewaters must obtain a National Pollutant Discharge Elimination System (NPDES) permit. CWA regulations address technology-based effluent limitations, water quality-based effluent limitations, new source performance standards, control strategies for toxic pollutants, and thermal discharges. Water quality criteria established under the CWA may become ARARs for CERCLA cleanups. At the state level, water pollution is controlled through the Tennessee Water Quality Control Act and implementing regulations. The NPDES permit program is administered by the Division of Water Pollution Control within the TDEC.

On October 6, 1992, the Federal Facilities Compliance Act (FFCAct) became law. This statute amended RCRA such that the federal government would be liable to all solid and hazardous waste regulations in the same manner as private persons and companies. This constitutes the waiver of sovereign immunity by the U.S. government allowing civil suits to be filed against it by the states and private parties. Some of the provisions of this act include a 3-year moratorium on the enforcement of mixed waste and radioactive regulations, an inventory of mixed wastes at all federal facilities, and a listing of available treatment technologies for those inventories. It is possible that this act will replace the FFCA as the mechanism for establishing compliance in mixed waste on the ORR. However, at this time both the FFCAct and the FFCA are being adhered to separately.

The Safe Drinking Water Act (SDWA) sets regulatory standards for organic chemicals and other pollutants in drinking water through two regulatory programs: National Drinking Water Standards for Public Water Systems and Underground Well Injection. SDWA Primary Drinking Water Standards are frequently used to establish groundwater protection standards pursuant to RCRA and CERCLA.

There are other numerous state regulations applicable to ORNL waste management activities for which compliance must be ensured. The bulk of these fall under a series of rules identified as Tenn. 1200 rules.

\subsubsection{DOE Orders}

DOE and DOE contractors are subject to the requirements of DOE orders in addition to the requirements of federal and state regulatory agencies. Therefore DOE orders impact waste management processes as well. DOE orders of significance to waste management are summarized in the following paragraphs. 
DOE Order 5820.2A establishes policies, guidelines, and minimum requirements for managing radioactive and mixed wastes. This order requires that DOE LLW be managed to protect public health and safety and to preserve the environment. The order also requires that a Performance Assessment of all aspects of waste management be conducted.

Chapter V of DOE Order 5820.2A sets forth requirements for decommissioning radioactively contaminated facilities. Planning for facility decommissioning must be initiated during the Design Phase for new facilities and before termination of operations for existing operational facilities, and must consider the 2-year budget cycle to ensure adequate funding availability. Decommissioning project activities include facility characterization, the environmental review process (i.e., NEPA, RCRA, CERCLA, and SARA), and technical engineering planning, which includes a Decommissioning Project Plan. Status reports on project activities must be prepared in accordance with DOE Order 1332.1 A or 4700.1.

In December 1991 several rules appeared in the Code of Federal Regulations codifying existing DOE orders. Following is a summary of those rules:

- "Procedural Rules for DOE Nuclear Activities" (10 CFR Pt. 820) sets forth the procedures to govern the conduct of persons involved in DOE nuclear activities and, in particular, to achieve compliance with the DOE Nuclear Safety Requirements by all persons subject to those requirements. The subparts of $10 \mathrm{CFR}$ Pt. 820 are "Enforcement Process," "Compliance Orders," "Interpretations," "Exemption Relief," "Criminal Penalties," and "Enforcement of Technical Specifications Operational Safety Requirements." An appendix to 10 CFR Pt. 820 is a general statement of enforcement policy that includes tables of civil penalties and severity levels. This proposed rule was finalized effective September 16, 1993.

- "Nuclear Safety Management"' (10 CFR Pt. 830) provides rules to govern the conduct of DOE contractors and other persons at DOE nuclear facilities. In addition to providing a definition of a nonreactor nuclear facility that significantly broadens the nature of facilities in that category, and a definition of graded approach, the subparts of $10 \mathrm{CFR}$ Pt. 830 include "Design," "Operations," and "Material Management." Within these subparts are 28 separate sections. Eleven of those sections are complete and include subjects such as "Safety Analysis Reports," "Quality Assurance Requirements," "Training and Certification," "Maintenance Management," and "Conduct of Operations." Sections that are assigned but have no content yet include subjects such as "Configuration Management," "Fitness for Duty," "Fire Protection," "Design Criteria," "Criticality Safety," and "Packaging and Transportation."

- "Radiation Protection for Occupational Workers" (10 CFR Pt. 835) establishes radiation protection standards, limits, and program requirements for protecting workers and other persons from ionizing radiation at DOE facilities. This rule is the most detailed of the three published so far, and includes subparts that describe "Radiation Protection Programs," "Standards for Internal and External Exposure," "Monitoring in the Workplace," "Entry Control Programs," "Posting and Labeling," "Records," "Reports to Employees," "Radiation Safety Training," "Design Control," "Release of Material and Equipment from Radiological Areas," and "Accidents and Emergencies."

- "Radiation Protection of the Public and the Environment" (10 CFR Pt. 834) was issued on March 25, 1993. DOE is proposing this rule as a primary standard for the protection of the public and environment against radiation. The requirements would be applicable to the conirol of radiation exposures to the public and to the environment from normal operations. 
Postdecommissioning activities involve final chemical and radiological surveys and preparation of a project final report. The responsible field organization will compile a Project Data Package. Long-term maintenance, surveillance, and other safety controls will be provided by the responsible program organization. The decommissioned property may be released from DOE ownership according to the requirements of DOE Order 4300.1B. DOE Order $5700.6 \mathrm{~B}$ requires that quality assurance be maintained by using the applicable requirements of American National Standards Institute/American Society of Mechanical Engineers, NQA-1, 1983, "Quality Assurance Program Requirements for Nuclear Facilities."

DOE Order 5400.2A establishes the DOE requirements for coordinating significant environmental compliance issues by creating a process within DOE for resolving conflicting compliance issues. DOE Order 5400.3 establishes DOE hazardous and radioactive mixed waste policies and requirements. The order clarifies DOE's interpretation of the definition of "byproduct material" (10 CFR Pt. 962) as it relates to RCRA regulation of mixed wastes and establishes the lines of authority at DOE Headquarters for RCRA implementation. CERCLA requirements are now addressed in DOE Order 5480.4. The order provides DOE policy resolving RCRA/CERCLA overlap issues, integrating NEPA with RCRA/CERCLA processes, and resolving organizational conflict of interest issues for RCRA/CERCLA contractors.

DOE Order $5440.1 \mathrm{C}$ provides DOE guidelines for developing and routing NEPA documentation. DOE Order 5480.3 establishes requirements for the packaging and transportation of hazardous materials, hazardous substances, and hazardous wastes. DOE Order 1540.1 establishes DOE policies for management of materials transportation activities. DOE Order 1540.2 establishes administrative procedures for the certification and use of radioactive and other hazardous materials packaging by $\mathrm{DOE}$.

Other relevant DOE orders include DOE Order 5400.1, which establishes the environmental monitoring, waste minimization, and pollution prevention requirements for DOE operation, and DOE Order 5480.1B, along with DOE Order 5400.5, both of which outline environmental protection safety and health protection policies and responsibilities.

\subsection{OVERALL GOALS}

The goal of the ORNL Waste Management Program is protection of the workers, the public, and the environment. A vital aspect of this goal is to comply with all applicable state, federal, and DOE requirements. Waste management requirements for DOE wastes are detailed in DOE Order 5820.2A, and the ORNL Waste Management Program encompasses all elements of this order. Compliance with the requirements of this DOE order and other appropriate DOE orders, along with applicable TDEC and EPA rules and regulations, provide the principal source of regulatory guidance for waste management operations at ORNL.

As a goal, ORNL continues to place increased emphasis on minimizing the amount of generated waste that will eventually require storage, treatment, and disposal. Steps taken to avoid generating waste help decrease risks to on-site personnel, the general public, and the environment and reduce operational costs. Another ORNL goal is to provide adequate storage, treatment, and disposal capacity for the waste that is expected to be generated.

The goals for managing TRU waste include the preparation of the waste for safe storage in an interim retrievable facility until facilities are available for permanent disposal. The Waste Isolation Pilot Plant, near Carlsbad, New Mexico, is the designated disposal site for TRU waste. 


\section{$1 \cdot 10$}

The goals for managing LLW are to treat the waste to reduce its volume and dispersability and to dispose of it in facilities that allow for increased environmental protection. More efficient storage, treatment, and disposal of LLW will reduce potential future liabilities.

The goals for managing hazardous waste and mixed wastes are very similar. By avoiding its generation and by destroying the hazardous nonradioactive constituents, the problems and costs associated with waste management may be minimized.

Industrial and sanitary wastes are managed with the goal of landfilling solid sanitary and industrial wastes in compliance with all applicable regulations. Operational goals are to reduce waste generation and to develop cost-effective improvements to ensure regulatory compliance and to reduce expenditures. 


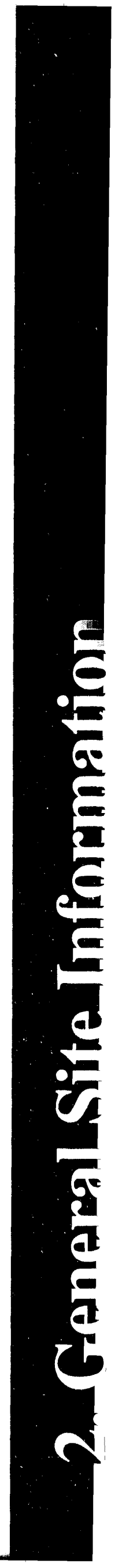




\section{GENERAL SITE INFORMATION}

This section provides the general characteristics of Oak Ridge National Laboratory (ORNL) operations: organization and administration, documentation, support activities, and site description.

\subsection{ORGANIZATION AND ADMINISTRATION}

\subsubsection{ORNL Mission}

ORNL, which is managed by Martin Marietta Energy Systems, Inc. (Energy Systems), for the U.S. Department of Energy (DOE), is one of the nation's priemier research institutions. The primary mission of the Laboratory is to perform leading edge research and development (R\&D) in support of the nonweapons roles of DOE. Especially important elements of ORNL's mission include performing basic and applied research important to the nation, providing unique national user facilities to the scientific and technical community, and partnering with universities and industry to improve the nation's competitiveness through technology development and transfer and through contributions to the national initiative to improve science and math education. ORNL will accomplish this mission through its core competencies:

- energy production, conservation, and utilization technologies;

- materials sciences and engineering;

- physical, chemical, and engineering sciences;

- biological and life sciences;

- environmental sciences and technologies;

- computational sciences; and

- manufacturing sciences and technologies.

\subsubsection{Historical Development of Waste Management at ORNL}

Since the beginning of operations at the site in 1943, significant changes have occurred in the scope of R\&D activities and in the supporting waste management requirements. While early site development focused on direct support of defense programs during and following World War II, the unique facilities that were established at that time formed the nucleus of the multidisciplinary research laboratory that now exists. Similarly, waste management requirements have changed over the years. Early waste management practices, which left significant environmental concerns unsatisfied, were a product of the limited scientific knowledge of the day and the urgency of the early mission. Compliant management of waste streams from ORNL facilities is now the continuing responsibility of DOE and its managing site contractors.

Over the past decade, awareness of environmental issues has increased, and major environmental legislation has been enacted at both the federal and state levels to control existing and potential sources of pollution. As a result of this changing regulatory environment, the number of inspections, audits, and reviews that have been conducted, including an evaluation by the DOE Tiger Team, have increased markedly. These have revealed the need to accelerate activities that protect ORNL employees, the general public, 
and the environment on a more comprehensive basis, particularly through standards, practices, and procedures that reduce hazards to the environment, the public, and the employee to as low as reasonably achievable. Facilities for treatment of discharges are being constructed or upgraded, and results of earlier disposal practices are being corrected. Action in this area will continue to bring ORNL into greater compliance with current and future regulations and guidelines. Effluent monitoring has been used to aid waste management operations and to ensure the safety of on-site personnel, the general public, and the environment.

\subsubsection{Waste Management Organizational Structures}

\subsubsection{DOE Headquarters organizational structure}

DOE was established by the Department of Energy Organization Act (421 U.S.C. 7131), effective October 1, 1977, pursuant to Executive Order 12009 of September 13, 1977. The act consolidated the major federal energy functions into one Cabinet-level department. Specific DOE responsibilities include:

- developing improvements in our current use of energy resources;

- conducting basic research in the sciences underlying efficient and effective energy use;

- protecting our society from the possible dangers of the by-products of nuclear plants, research medicine, and other applications;

- managing nuclear weapons production for strategic defense needs;

- delivering electric power through five power administrations;

- managing civilian and military petroleum reserves; and

- overseeing environmental restoration and waste of DOE nuclear and nonnuclear facilities.

In addition, DOE develops and maintains information on energy reserves, energy production, and possible future energy needs for use by the private and public sectors. The DOE Headquarters (DOE-HQ) organization (Fig. 2.1) includes the Economic Regulatory Administration, the Energy Information Administration, and the Federal Energy Regulatory Commission, which is an independent regulatory organization within DOE. Programs provided by DOE include Energy Research, Civilian Radioactive Waste Management, New Production Reactors, Environmental Restoration and Waste Management, Fossil Energy, Nuclear Energy, Conservation and Renewable Energy, and Defense Programs.

The Assistant Secretary for Environmental Restoration and Waste Management (EM) provides program policy guidance and manages the assessment and cleanup of inactive waste sites and facilities, continues safe and effective waste management operations, and develops and implements an aggressively applied waste $R \& D$ program to provide innovative environmental technologies that yield permanent disposal solutions at reduced costs. The Assistant Secretary provides centralized management for DOE for waste management operations, environmental restoration, and applied R\&D programs and activities, including EM policy and guidance to DOE field offices in these areas. Figure 2.1 shows the different offices reporting to the Assistant Secretary for EM and their titles. The programmatic direction from DOE-HQ to the DOE Oak Ridge Operations Office (DOE-ORO) for waste management activities is through the Office of Waste Management (EM-30). The Deputy Assistant Secretary for Waste Management utilizes two offices to discharge operational (EM-32) and program support (EM-33) guidance. The Office of Waste Operations (EM-32) is divided regionally into divisions; Eastern Operations (EM-321) provides programmatic guidance to DOE-ORO. 


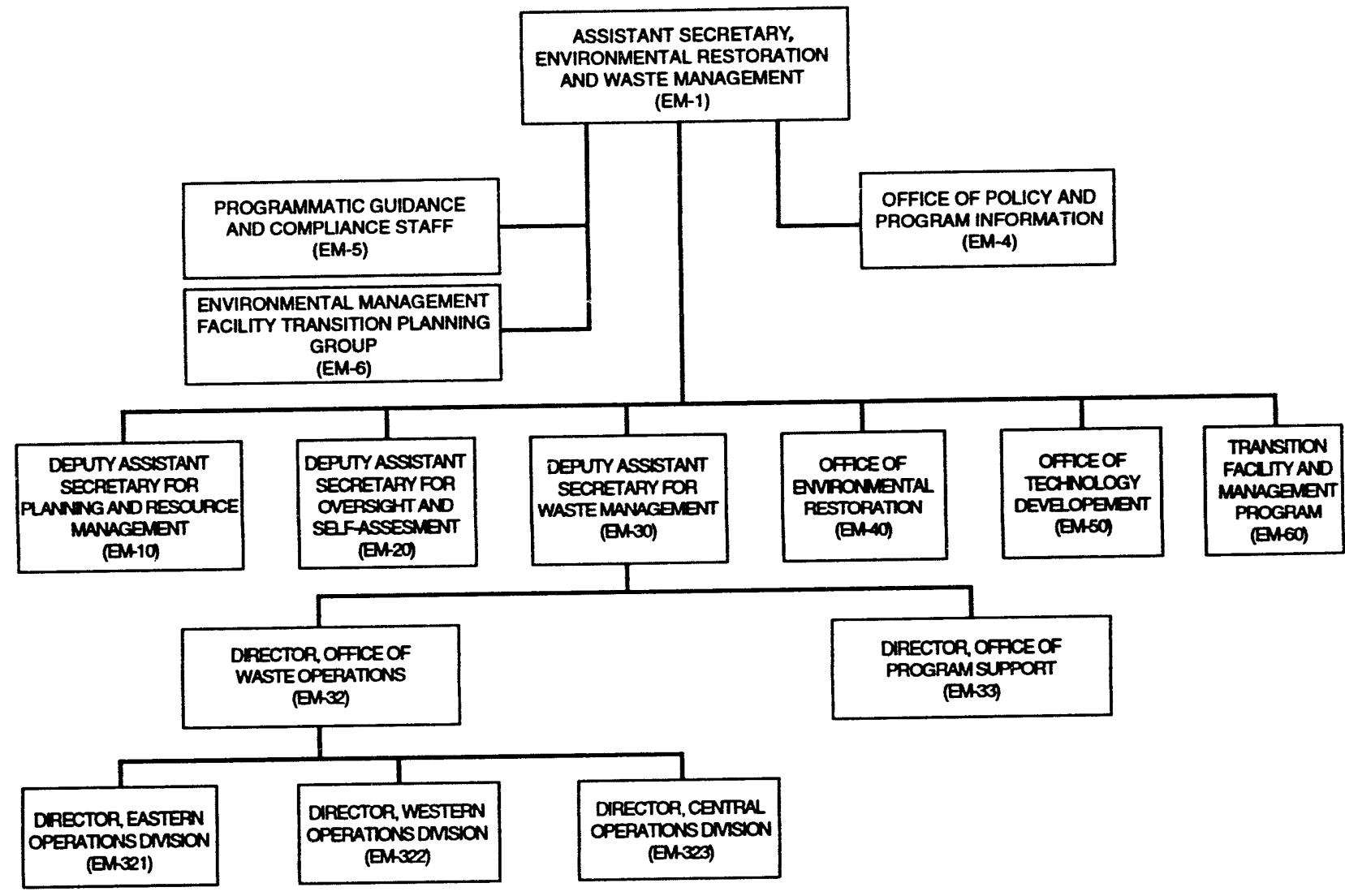

Fig. 2.1. U.S. Department of Energy Headquarters: organizational overview. 


\subsubsection{DOE-ORO}

DOE-ORO has placed the overall responsibility for all environmental restoration and waste management activities under the Assistant Manager for Environmental Restoration and Waste Management (AMERWM). Within AMERWM are three divisions and two site offices: Environmental Restoration, Waste Management and Technology Development, and Former Sites Restoration Divisions and Weldon Springs Site and Oak Ridge K-25 Site Offices (Fig. 2.2).

ORNL-DWG $91 \mathrm{M}-14682 \mathrm{R2}$

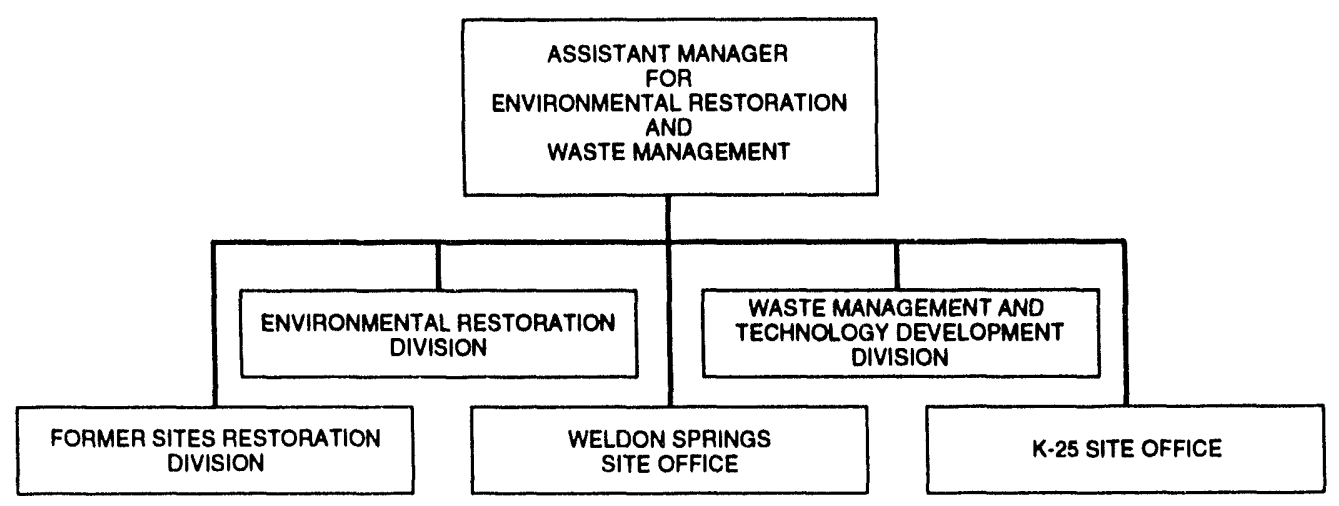

Fig. 2.2. AMERWM organization for the U.S. Department of Energy's Oak Ridge Operations Office.

Responsibility for overall planning, budget development, and program management of corrective activities and waste management operations for radioactive, hazardous, and mixed waste rests with the Waste Management and Technology Development Division under AMERWM. The Assistant Manager for Energy Research and Development Organization is the contractor officer's representative for ORNL. In addition to AMERWM and its associated responsibilities, the DOE-ORO Assistant Manager for Construction and Engineering is responsible for renovations and new construction projects and the associated architect engineers and construction managers.

\subsubsection{Martin Marietta Energy Systems, Inc.}

The three sites on the Oak Ridge Reservation (ORR) are operated for DOE by Energy Systems. As the operating contractor, Energy Systems manages the environmental, safety, and health (ES\&H) programs at the sites and supports DOE-ORO in management of the overall ES\&H Program. Energy Systems has a strong environmental management organization that is organized to parallel the DOE-ORO Environmental Restoration and Waste Management Organization.

Within Energy Systems, waste management, environmental restoration, and decontamination and decommissioning (D\&D) are the responsibility of the Environmental Restoration and Waste Management Programs. This organization has direct interface with the DOE-ORO AMERWM. 
At ORNL the Waste Management and Remedial Action Division (WMRAD) is responsible for operating the waste management systems in full compliance with all current regulations. Although WMRAD reports through the ORNL line organization to the ORNL director, it also reports to the Energy Systems Waste Management Organization (ESWMO). An organizational overview of the Energy Systems Environmental Restoration and Waste Management Programs is shown in Fig. 2.3.

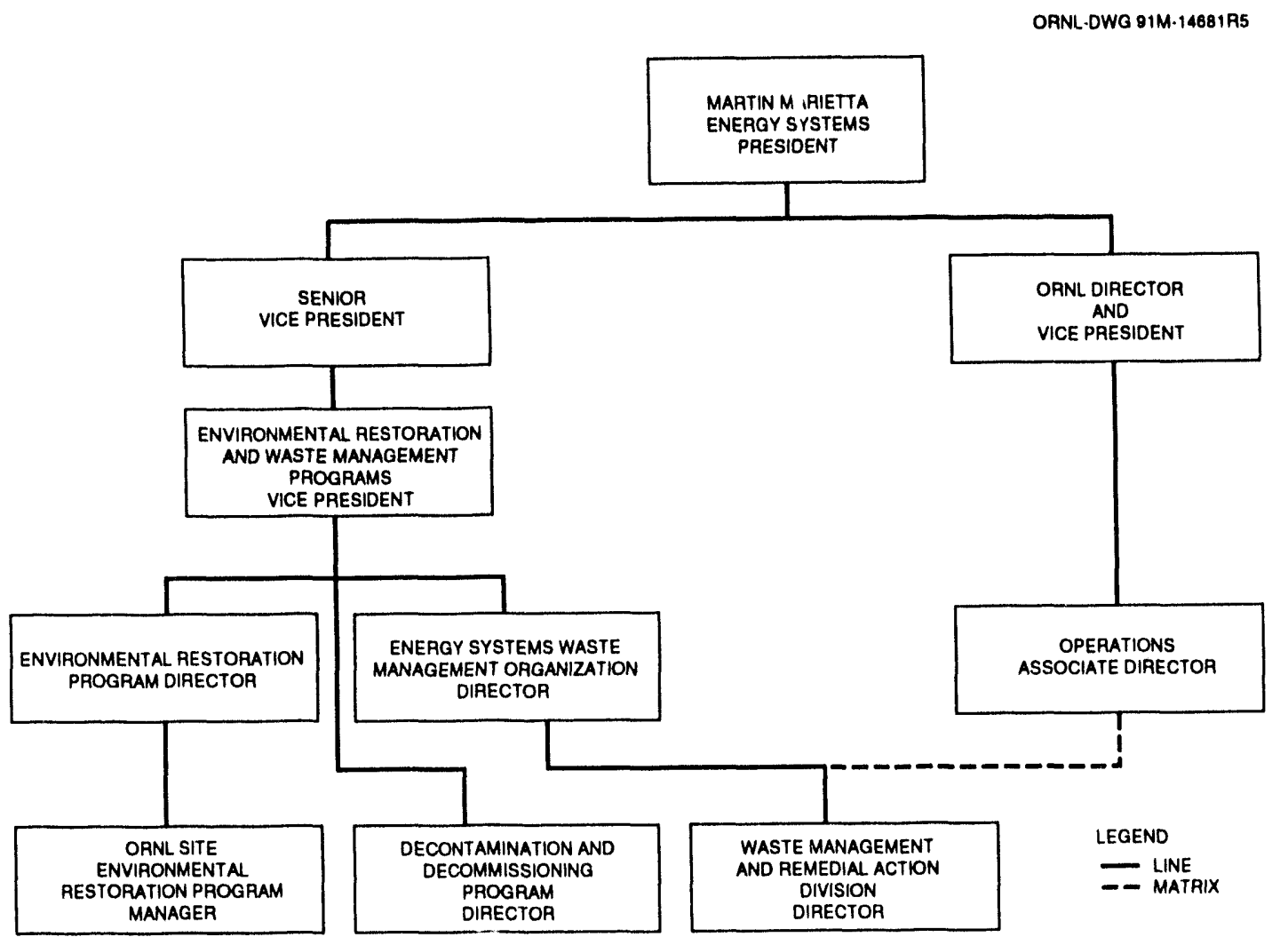

Fig. 2.3. Organizational overview for the Energy Systems Environmental Restoration, Decontamination and Decommissioning, and Waste Management Programs.

\subsection{Energy Systems Waste Management Organization}

The ESWMO reports to the Environmental Restoraiion and Waste Management Programs Vice President. ESWMO has responsibility for implementing Waste Management and Corrective Action Programs for ORR (Fig. 2.4). The mission of ESWMO covers these broad areas:

- ORR-wide Waste Management Program coordination;

- program planning and technical support for all radioactive, hazardous, medical and infections, mixed, and sanitary waste operations;

- waste reduction at Energy Systems facilities;

- development, coordination, and operation of centralized waste treatment, storage, and disposal facilities;

- budget planning; and

- program reporting for Waste Management and Corrective Action Programs. 
ORNL-DWG O1M-14680R3

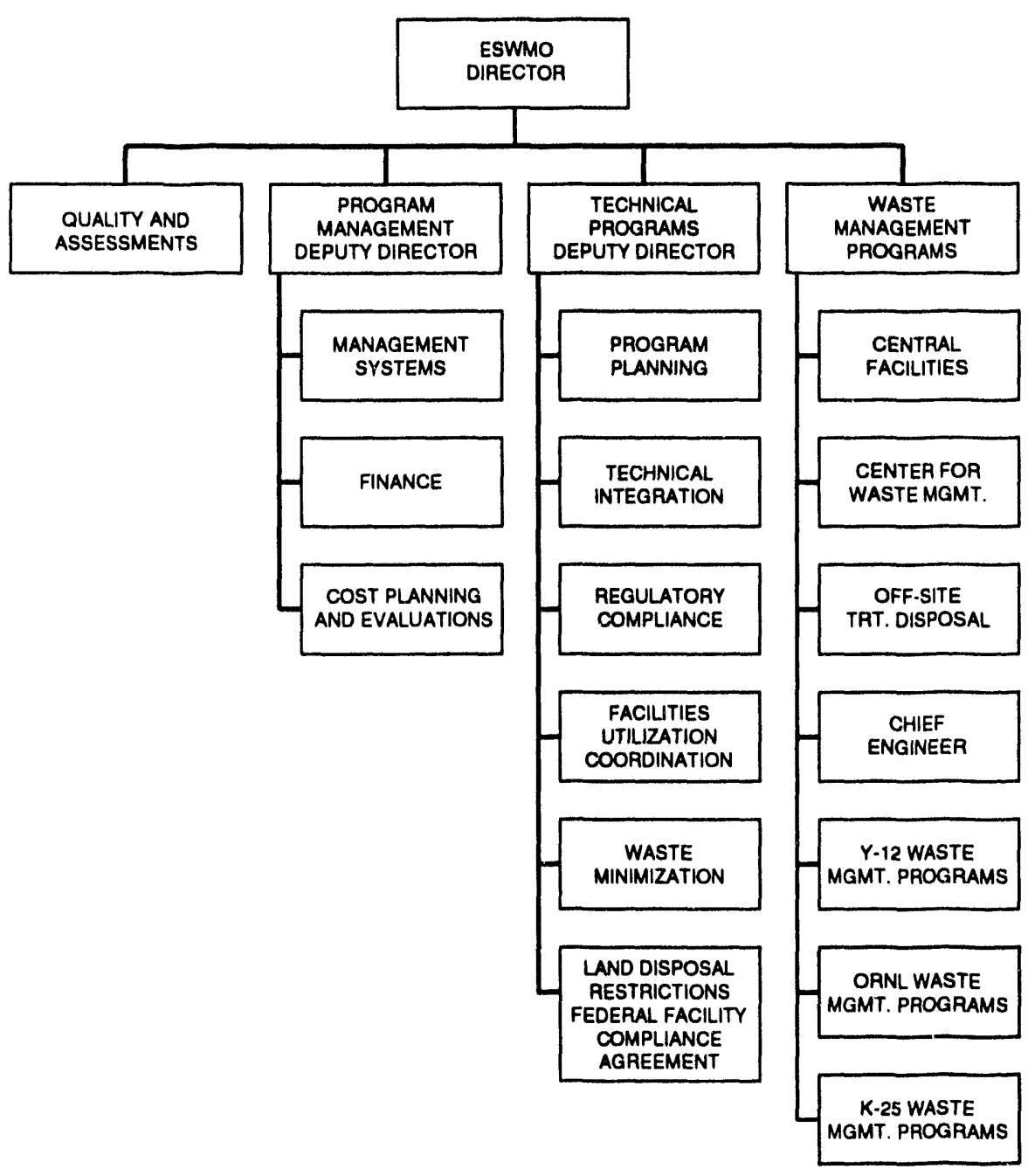

Fig. 2.4. Energy Systems Waste Management Organization.

The ESWMO has also been assigned the responsibility for preparation and issuance of radiological Performance Assessments (PAs), as required under DOE Order 5820.2A, for ORR low-level waste disposal sites. The ESWMO assigned the responsibility for developing Solid Waste Storage Area (SWSA) 6 and the Interim Waste Management Facility PA to WMRAD.

\subsection{ORNL Waste Management and Remedial Action}

Waste management operations at ORNL are the direct responsibility of WMRAD (Fig. 2.5). This division is responsible for the continued operation of the radioactive, hazardous, and mixed waste management systems at ORNL in a manner that protects the health and safety of workers and the general public, minimizes impacts to the environment, 
ORNL-DWG 92M-12841R

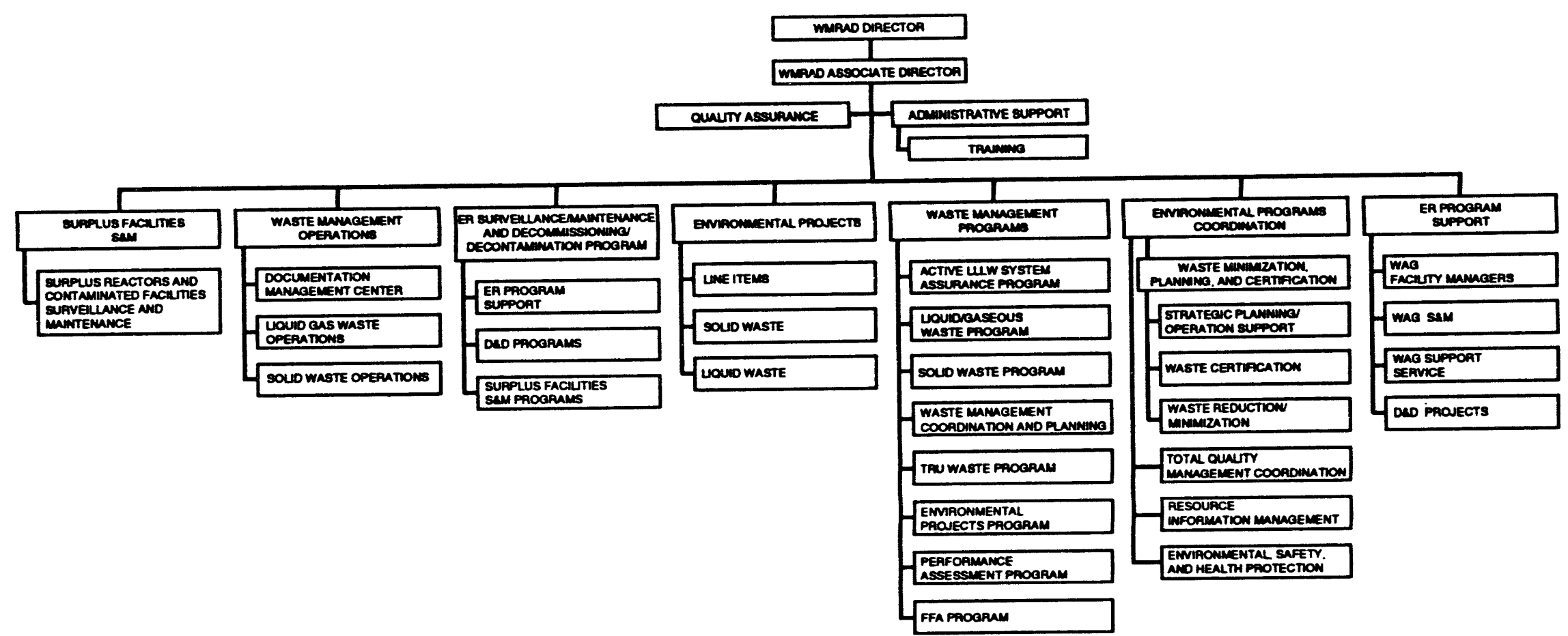

Fig. 25. Organization of the Waste Management and Remedial Action Division at Oak Ridge National Laboratory. S\&M-surveillance and maintenance; D\&D-decontamination and decommissioning; FFA-Federal Facilities Agreement: ER-Environmental Restoration; WAG-Waste Area Group. 
and complies with all applicable regulations, rules, and policies. The division is also responsible for remedial action functions that cover surveillance and maintenance (S\&M) of inactive waste sites and surplus radioactively contaminated facilities and D\&D of the contaminated facilities. WMRAD is comprised of five line management sections and two matrixed programs. The five sections are Waste Management Operations, Environmental Projects, Environmental Programs Coordination, Surplus Facilities S\&M, and Environmental Restoration Program (ERP) Support. The two programs are Waste Management and Decontamination and Decommissioning.

The Waste Management Program has programmatic responsibility for seven areas: solid waste activities; liquid and gaseous waste activities; coordination, certification, and strategy development; environmental project management; transuranic (TRU) waste management; fiscal analysis and reporting; and active Liquid Low-Level Waste (LLLW) System compliance management. This section reports to the director of WMRAD but is programmatically responsible to the director of the ESWMO. The D\&D Program is responsible for management of the ORNL D\&D Program.

The Waste Management Operations Section is responsible for the management and operation of the hazardous, radioactive, mixed, and sanitary solid waste systems. It is made up of two major departments: the Liquid and Gaseous Waste Operations Department (LGWOD) and the Solid Waste Operations Department (SWOD).

The LGWOD is responsible for the safe operations necessary for management of a number of ORNL liquid and gaseous waste streams. The liquid waste streams include radioactive process waste, radioactive LLLW, and various wastewater streams. The LGWOD is not responsible for sanitary liquid waste streams including coal yard runoff, sewage, or any liquid waste streams released to the watershed without treatment. The sanitary liquid waste streams are the responsibility of the Plant and Equipment Division at ORNL. The gaseous waste streams include those flows in the main ORNL plant area terminating at the 3039 stack. The LGWOD is not responsible for gaseous wastes going to other stacks at ORNL.

The SWOD is responsible for ensuring the proper characterization, storage, treatment, recycle, and/or disposal of radioactive, hazardous, mixed, and sanitary solid wastes. ORNL waste management facilities include SWSA $5 \mathrm{~N}$ for TRU and special case wastes, the SWSA 6 disposal site for solid low-level waste, the Hazardous/Mixed Waste Management Area, and other hazardous/mixed waste tanks or facilities.

The Environmental Projects Section provides engineering support to manage line items (LIs) and general plant projects (GPPs) during functional/systems requirements definition, feasibility studies, conceptual design, detailed design, procurement, and construction. The $\mathrm{LI}$ and GPP are required for upgrading, replacing, or constructing new facilities or systems required to conduct waste management operations in an efficient, safe, and compliant manner.

The Environmental Programs Coordination Section provides integration for strategic and long-range planning activities, project tracking, fiscal analysis, and periodic progress reporting. Planning documents include the DOE Environmental Restoration and Waste Management Five-Year Plan, Fiscal Years 1994-1998, the supporting Environmental Restoration and Waste Management Site-Specific Plan for the Oak Ridge Operations Reservation, and the Current Year Work Plan.

The Waste Minimization, Planning, and Certification Department provides detailed strategy development and planning for continuity of waste management system operations. The major function of this office is to develop viable strategies for the compliant management of ORNL waste operations and to identify the need for the upgrade, 
replacement, and construction of new facilities. This department also develops and maintains central programs for waste certification, generator training, and waste reduction.

The Environmental Restoration D\&D, S\&M Programs Section, is responsible programmatically for all work conducted for the ERP, which includes programmatic interfaces with the ORNL site manager of the ERP and the Energy Systems D\&D Program manager. This section also provides the interface necessary with the ORNL Capital Asset Planning Group for surplus facilities support received from DOE Energy Research.

The Surplus Facilities S\&M Section is responsible for S\&M of the growing number of ORNL's surplus contaminated facilities. The growth of responsibility in this area has led to the formation of the ERP Support Section.

The ERP Support Section was formed in September 1993 to implement work performed by WMRAD for the ORNL site manager of the Energy Systems Environmental Restoration Program. This section will be responsible for activities involving S\&M of remediation sites. Also, those D\&D projects that are closely associated with remediation planning and implementation will also be performed by this section.

The regulatory oversight of waste management systems operations is maintained by the ES\&H compliance organization shown in Fig. 2.6. Within this organization is the office of Environmental Compliance and Documentation's Environmental Compliance Section. The Environmental Compliance Section provides guidance concerning environmental protection standards and regulatory requirements to ORNL staff and management to facilitate compliance with those standards and requirements. This group also prepares, or coordinates the preparation of, all regulatory permit applications and oversees the negotiation of these into operating permits.

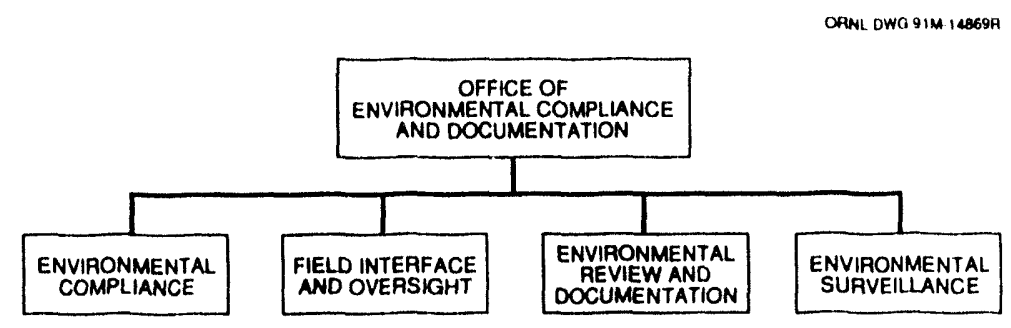

Fig. 2.6. Organization of the Office of Environmental Compliance and Documentation at Oak Ridge National Laboratory.

\subsection{DOCUMENTATION}

Various documents are developed to guide and to support the Waste Management Program at ORNL; the Documentation Management Center (DMC) at ORNL is responsible for maintaining current revisions of all waste management documents. Information regarding both the applicable documents and the DMC is provided in the following subsections.

\subsubsection{ORNL Waste Management Guidance and Support Documents}

In addition to the Oak Ridge National Laboratory Waste Management Plan, the following documents are used to guide and to support the ORNL Waste Management Program: 
- the DOE Environmental Restoration and Waste Management Five-Year Plan, Fiscal Years 1994-1998,

- the Environmental Restoration and Waste Management Site-Specific Plan for the Oak Ridge Operations Reservation (SSP),

- Activity Data Sheets (ADSs),

- the Current Year Work Plan (CYWP),

- strategy documents, and

- the Active Sites Environmental Monitoring Program: Program Plan.

\subsubsection{The DOE Five-Year Plan}

The DOE Environmental Restoration and Waste Management Five-Year Plan, Fiscal Years 1994-1998 is the cornerstone of DOE's long-term strategy planning in environmental restoration and waste management. The plan captures the results of a comprehensive annual planning process that involves the entire organization and its stakeholders. The plan is revised annually in accordance with the provisions of the National Defense Authorization Act to incorporate departmental progress and to reflect changes in planning as more definitive cost estimates are developed for those actions required to meet compliance obligations. This plan encompasses all radioactive, hazardous, mixed, and solid sanitary waste activities including applied R\&D activities to accelerate the deployment of new technologies in achieving better results at lower costs.

This plan encompasses three discrete activity areas: corrective activities, environmental restoration, and waste management operations. "Corrective activities" denotes activities necessary to bring active and standby facilities into compliance with federal, state, and local regulations. "Environmental restoration" includes the assessment and cleanup of surplus facilities and inactive sites. Waste Management Operations is concerned with the storage, treatment, and disposal of wastes generated as a result of current operations at active facilities.

\subsubsection{DOE-ORO's Environmental Restoration and Waste Management Site-Specific Plan}

The DOE Environmental Restoration and Waste Management Five-Year Plan, Fiscal Years 1995-1999, serves as a source document for a detailed site-specific implementation plan prepared by DOE-ORO. This plan encompasses environmental restoration and waste management activities at Oak Ridge facilities including ORNL. The OR SSP describes FY 1994 activities and provides funding summaries as well as descriptions of organizational structures, regulatory issues, reporting requirements, and quality assurance (QA) programs. The SSP is the vehicle for participation by affected parties at the regional/local level. It is also used by the DOE-ORO and DOE Headquarters to measure progress in meeting DOE's goal for environmental cleanup, waste operations, and technology development activities. In support of the OR SSP, ORNL prepares the ORNL portion, which is then combined with portions from the Oak Ridge K-25 Site and the Y-12 Plant.

\subsubsection{Activity Data Sheets}

ADSs are used by ORNL to identify all invironmental restoration, waste management, and corrective action projects; appropriate information on priority and funding levels, budget reporting codes, and a short narrative description are provided. ADSs, the basic unit of description necessary to develop the comprehensive DOE Environmental 
Restoration and Waste Management Five-Year Plan, Fiscal Years 1995-1999, will be updated annually. The 1995 ADSs were completed by April 1993 to support the 1995 budget submission. A list of the regulatory drivers is shown in Table 2.1.

Table 2.1. Oak Ridge National Laboratory waste management Activity Data Sheets for FY 1995 and related regulatory drivers

\begin{tabular}{|c|c|}
\hline Regulatory driver & FY 1995 ADS \\
\hline $\begin{array}{l}\text { Federal Facilities Agreement, Sect. IX and } \\
\text { Appendix F }\end{array}$ & $\begin{array}{l}3101,3102,3201,3203,3204,3206,3251,3252 \text {, } \\
3253 \text {, and } 3254\end{array}$ \\
\hline $\begin{array}{l}\text { National Pollutant Discharge Elimination System; } \\
\text { Tenn. Rule 1200-4-5, Water Pollution Control } \\
\text { Regulations }\end{array}$ & $3201,3204,3205,3207,3252,3253$, and 3255 \\
\hline $\begin{array}{l}\text { Federal Facilities Compliance Agreement (FFCA) } \\
\text { for National Emission Standards for Hazardous } \\
\text { Air Pollutants--Radionuclides; Resource } \\
\text { Conservation and Recovery Act (RCRA) land } \\
\text { disposal restrictions FFCA; RCRA Part A and } \\
\text { Part B permits; Tenn. Rule 1200 [1-11-.02; } \\
1-11-.02(3)(\mathrm{e}) ; 1-11-.03(1)(\mathrm{b}) ; 1-11-.05 ; 1-11-.06 \text {; } \\
1-11-.07 ; 1-11-.10 ; 1-15 ; 3-1 \text { through } 3-26 \text {, Air } \\
\text { Pollution Control Regulations; and 4-1 through } \\
\text { 4-5, Water Pollution Control Regulations] }\end{array}$ & $\begin{array}{l}3201,3202,3203,3204,3205,3207,3251,3252 \text {, } \\
\text { and } 3253\end{array}$ \\
\hline
\end{tabular}

\subsubsection{Current Year Work Plan}

CYWPs, prepared for programmatic waste management tasks and corrective activities each fiscal year, include the following information:

- the task description,

- activities to be performed,

- milestones,

- resources necessary to perform the task,

- impacts of not doing the task, and

- the task budget and spending schedule,

The budget information provided in the CYWP is developed to be consistent with guidance received from the ESWMO and DOE-ORO.

\subsubsection{Documentation Management Center}

The DMC maintains quality records for the ORNL Waste Management Operations Section (among others) by use of the Documentation Management System (DMS), which was conceived, designed, and configured by the DMC to meet DOE Order 5700.6C requirements for document control and quality records. The scope and requirements of this QA-based system operation are contained in the Waste Management Operations Section Procedure, WM-DMC-101. For additional information on the DMS, see Subsect. 9.5 of this plan. 


\subsection{SITE DESCRIPTION}

This subsection briefly describes the physical characteristics of the ORNL site that are relevant to waste management activities.

\subsubsection{Location and Size}

ORNL, one of three industrial complexes located on the DOE ORR, is located in an area of hills and valleys $\sim 12.87 \mathrm{~km}(\sim 8$ miles) southwest of the city of Oak Ridge in eastern Tennessee (Fig. 2.7). The ORR 15,322 ha (38,306 acres) is in a rural setting and is bounded by the Clinch River and Tennessee Valley Authority (TVA) land on its eastern, southern, and western borders. ORNL is located on the southern border of the federal Reservation.

ORNL and its accompanying buffer zone, encompassing 3508 ha (8771 acres), is situated almost entirely within the $16.8-\mathrm{km}^{2}\left(6.5-\mathrm{mi}^{2}\right)$ White Oak Creek (WOC) drainage basin. The central ORNL Complex area is located in Bethel Valley (Fig. 2.8), which runs approximately in a northeast-southwest direction. Although the valley floor is highly developed within the central site area, the surrounding terrain is wooded. WOC passes to the south of the developed area and leaves the valley through a gap in Haw Ridge into Melton Valley. All the satellite facilities are located in Melton Valley except the Tower Shielding Facility, which is on Copper Ridge, south of Melton Valley. A number of ORNL facilities including the Biology Division are located at the Y-12 Plant.

The central ORNL Complex, the SWSAs, and the outlying facilities (Fig. 2.8) occupy $\sim 701$ ha $(\sim 1754$ acres $)$, or $\sim 20 \%$ of the entire ORNL site. The remaining 2806 ha ( 7017 acres), or $80 \%$ of the entire ORNL site, is predominantly forested buffer zone.

Most of the land on the ORR is subject to forest management administered through the P\&E Division at ORNL. Forest management on the ORR has involved such practices as the planting of pines on abandoned agricultural lands after acquisition of the land by the federal government in the 1940s and 1950s, clearing of immature second-growth hardwoodpine forests for planting of pine, and thinning and cutting of both hardwood and pine forests for pulpwood and sawtimber. Forest management objectives are coordinated with those of other land uses on the ORR, such as waste management activities.

\subsubsection{Demography}

Except for the city of Oak Ridge, the land within $8 \mathrm{~km}$ ( 5 miles) of the ORR is predominantly rural and is used largely for residences, small farms, and pasture land. Fishing, boating, water skiing, and swimming are favorite recreational activities in the area. The approximate location and population (1980 census data) of the towns nearest the ORR are Oak Ridge (pop. 28,000); Oliver Springs (pop. 3600), $10.9 \mathrm{~km}$ (6.8 miles) to the northwest; Clinton (pop. 5300), $16 \mathrm{~km}$ (10 miles) to the northeast; Lenoir City (pop. 5400), $10.9 \mathrm{~km}$ (6.8 miles) to the southeast; Kingston (pop. 4400$), 10.9 \mathrm{~km}$ (6.8 miles) to the southwest; and Harriman (pop. 8300), $12.9 \mathrm{~km}$ ( 8 miles) to the west. Knoxville, the major metropolitan area nearest Oak Ridge, is located about $40.3 \mathrm{~km}$ (25 miles) to the east and has a population of about 183,000 . Fewer than 5000 people live within $9.7 \mathrm{~km}$ (6 miles) of the ORR center. The TVA Melton Hill and Watts Bar reservoirs on the Clinch River form the southern, eastern, and western boundaries of the ORR, and the residential sector of the city of Oak Ridge forms the northeastern boundary. 
ORNL-OWG $82 \cdot 12547 R 5$

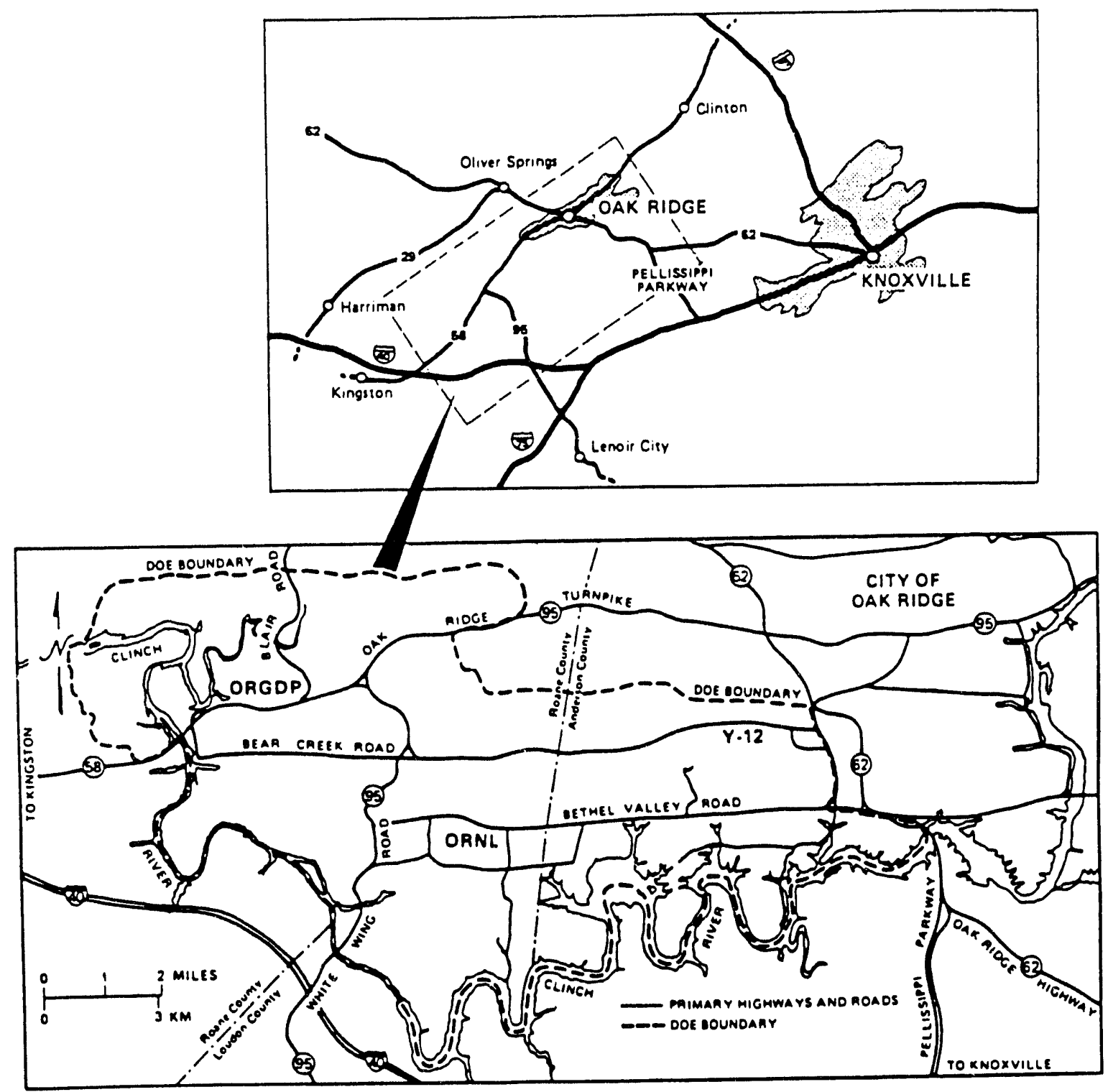

Fig. 2.7. Area map indicating location of Oak Ridge National Laboratory.

\subsubsection{Site Topography}

Site topography is characterized by a series of alternating, elongated, and parallel valley troughs and ridges trending northeast to southwest in general accord with the strike of the underlying rock strata. The valleys have been eroded in areas underlain by the less resistant limestone and shale strata, while the ridges are underlain by more resistant sandstone, shale, and cherty dolomite formations. 


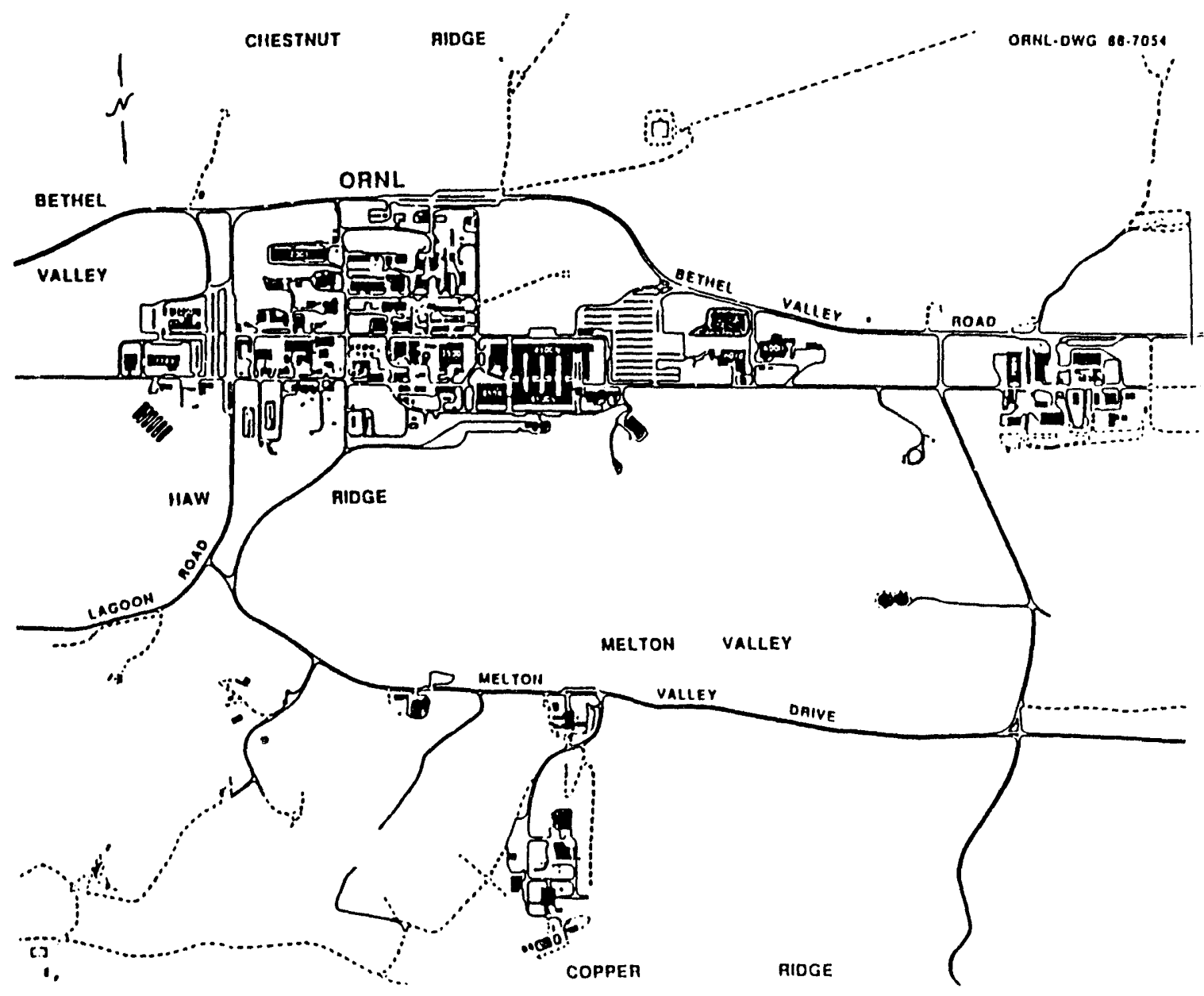

Fig. 2.8. Layout of the central Oak Ridge National Laboratory Complex in Bethel Valley.

Surface elevations range from $\sim 225 \mathrm{~m}(\sim 740 \mathrm{ft})$ at the Clinch River to $\sim 413 \mathrm{~m}$ $(\sim 1356 \mathrm{ft})$ at the crest of Melton Hill. The succession of alternating ridges and valleys in the ORNL site area (in order from the Clinch River in the southeast to the northwest) is as follows: Copper Ridge, Melton Valley, Haw Ridge, Bethel Valley, and Chestnut Ridge.

\subsubsection{Climate}

The Oak Ridge climate is typical of the humid southern Appalachian region. The local climate is noticeably influenced by topography. The prevailing winds, as measured by an on-site meteorological tower, are from the southwest and northeast under both stable and unstable conditions. Average monthly wind speeds range from $1.6 \mathrm{~m} / \mathrm{s}(5.2 \mathrm{ft} / \mathrm{s})$ in October to $2.5 \mathrm{~m} / \mathrm{s}(8.2 \mathrm{ft} / \mathrm{s})$ in April. Differences in elevation have a measurable influence on the changes in climate along a northwest-southeast axis. The average annual precipitation measured in the Oak Ridge vicinity is $138 \mathrm{~cm}$ (54.4 in.), ranging from $94.9 \mathrm{~cm}$ (37.4 in.) to $186.9 \mathrm{~cm}$ (76.3 in.). A trace or more of snow has been reported each winter on record; the annual average snowfall is $26.4 \mathrm{~cm}$ (10.4 in.). 


\subsubsection{Geologic and Hydrogeologic Conditions}

Nine geologic formations (Fig. 2.9) or groups ranging in age from Early Cambrian to Early Mississippian have been mapped within the ORR. All the formations are of sedimentary origin, either chemical (limestone and dolomite) or clastic (sandstone and shale). From oldest to youngest, they include the Rome Formation, the Conasauga Group, the Knox Group, the Chickamauga Group, the Sequatchie Formation, the Rockwood Formation, the Chattanooga Shale, the Maury Formation, and the Fort Payne Chert.

Of the nine units mapped within the Reservation, the four that underlie ORNL and the WOC drainage basin from northwest to southeast are (1) the Knox Group, a predominantly dolomite strata of Cambrian and Ordovician ages underlying Chestnut Ridge to the north and Melton Hill and Copper Ridge to the south; (2) the Chickamauga Group of Ordovician age, which underlies the main ORNL Complex in Bethel Valley; (3) the Rome Formation, shale, siltstone and sandstone unit of Cambrian age that underlies Haw Ridge, separating the main ORNL Complex from the satellite facilities located in Melton Valley; and (4) the Conasauga Group, Cambrian-age shales interbedded with limestones and siltstone that underlie the waste management storage, treatment, and disposal facilities in Melton Valley.

The rock is generally covered by a mantle of residual alluvial and colluvial material in places $>30 \mathrm{~m} \mathrm{(>100} \mathrm{ft)} \mathrm{thick.} \mathrm{Soils} \mathrm{developed} \mathrm{on} \mathrm{the} \mathrm{Rome,} \mathrm{Conasauga,} \mathrm{and}$ Chickamauga are generally thin [i.e., $<4.8 \mathrm{~m}(<16 \mathrm{ft})$ but somewhat thicker where shale is deeply weathered]. Knox residuum is generally thick but irregular.

In the Oak Ridge area the Knox dolomite and the Rome Formation are the principal aquifers. The Conasauga Group is a potential low-yield groundwater source. The Knox, located beneath Chestnut Ridge, is the major aquifer in the WOC basin. The thick, weathered mantle seems to have a high-infiltration capacity and serves as a reservoir feeding large solution cavities in bedrock. Springs at the base of Chestnut Ridge are a primary natural source of base flow for WOC. Groundwater discharge from the Knox beneath Copper Ridge is probably not into WOC basin but, instead, to the southeast along the Clinch River.

The mean yield of springs and wells in the Knox Group used for public and industrial water supplies is $1014 \mathrm{~L} / \mathrm{min}(268 \mathrm{gal} / \mathrm{min})$. No estimate is available for mean well yield of domestic water wells in the Knox Group.

Depth to the water table varies both spatially and temporally. At a given location, depth to water is generally greatest during the October-December quarter and least during the January-March quarter. In Bethel Valley, depth to water table ranges from 0.30 to $10.7 \mathrm{~m}$ ( 1 to $35 \mathrm{ft}$ ), while in Melton Valley the range is from 0.30 to $20.4 \mathrm{~m}$ ( 1 to $67 \mathrm{ft}$ ). Seasonal fluctuations tend to be greatest beneath hillsides. A seasonal variation of as much

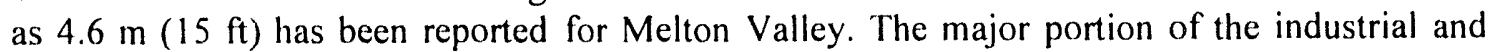
drinking water supplies in the Oak Ridge area is taken from surface water sources. However, single-family wells are common in adjacent rural areas not served by public water supply systems. For more detailed information concerning the hydrologic and geologic conditions affecting the ORR, Status Report-A Hydrologic Framework for the Oak Ridge Reservation should be consulted. 
ORIN OWG 82-14313RA

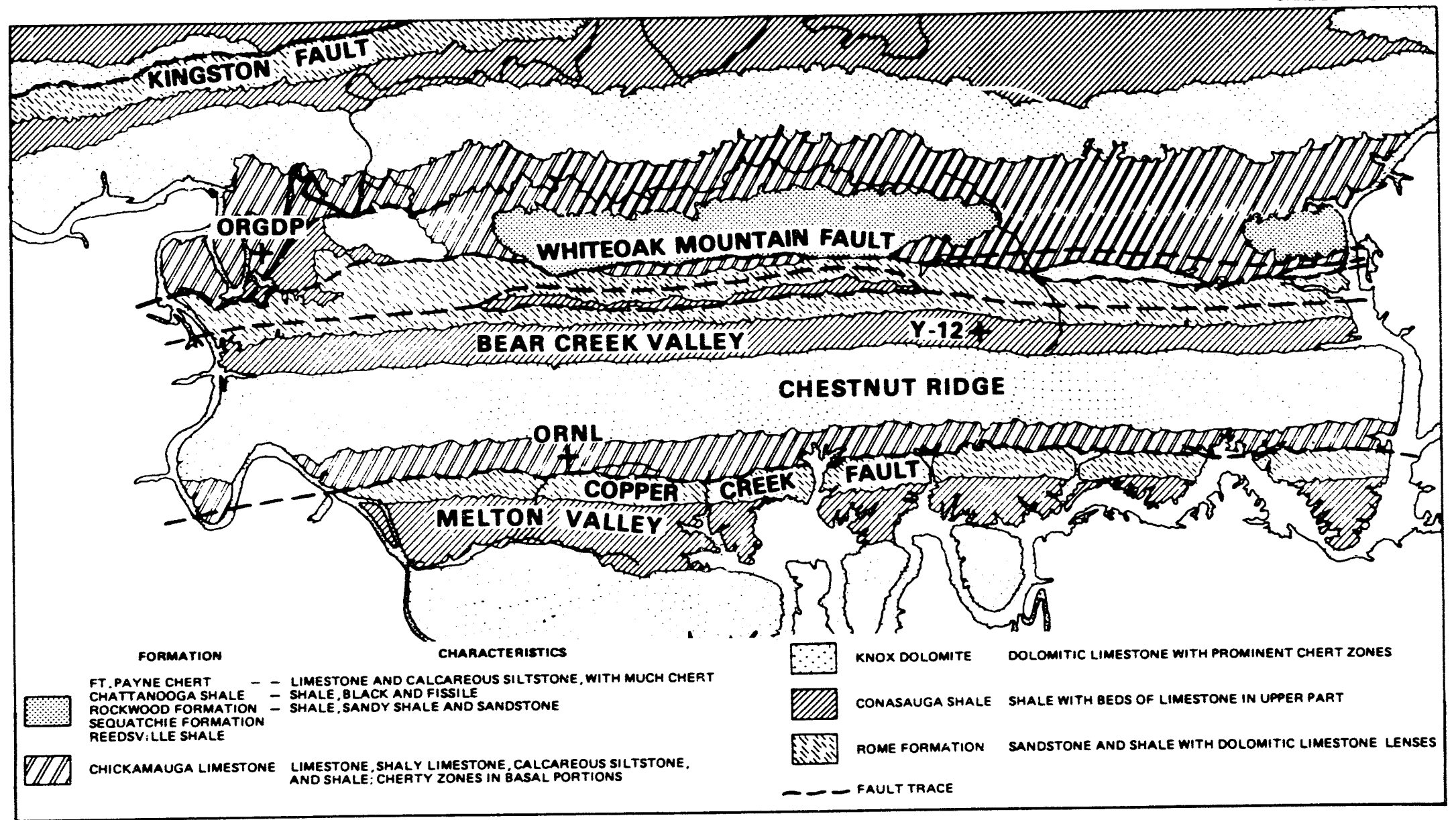

Fig. 2.9. Geologic formations within the Oak Ridge Reservation. 
4

2

60

$D$

$\leq$

a

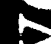

r

es

6

1

or

7

6

$a$ $\Omega$ 


\section{RADIOACTIVE WASTE}

Oak Ridge National Laboratory (ORNL) radioactive waste management activities are primarily concerned with transuranic (TRU) waste and low-level wastes (LLW). Small quantities of naturally occurring and accelerator-produced radioactive material (NARM) are generated and managed as LLW. ORNL does not generate high-level waste (HLW) but stores a small quantity of special case (SC) waste such as irradiated and spent nuclear fuel. Radioactive waste management operations include solid, liquid, and gaseous waste management activities.

\subsection{SOLID WASTE}

At ORNL solid radioactive waste is segregated for on-site storage or disposal. The decision tree for segregation and disposition of the various types of radioactive waste generated at ORNL is presented in Fig. 3.1. The following subsections describe the strategy,

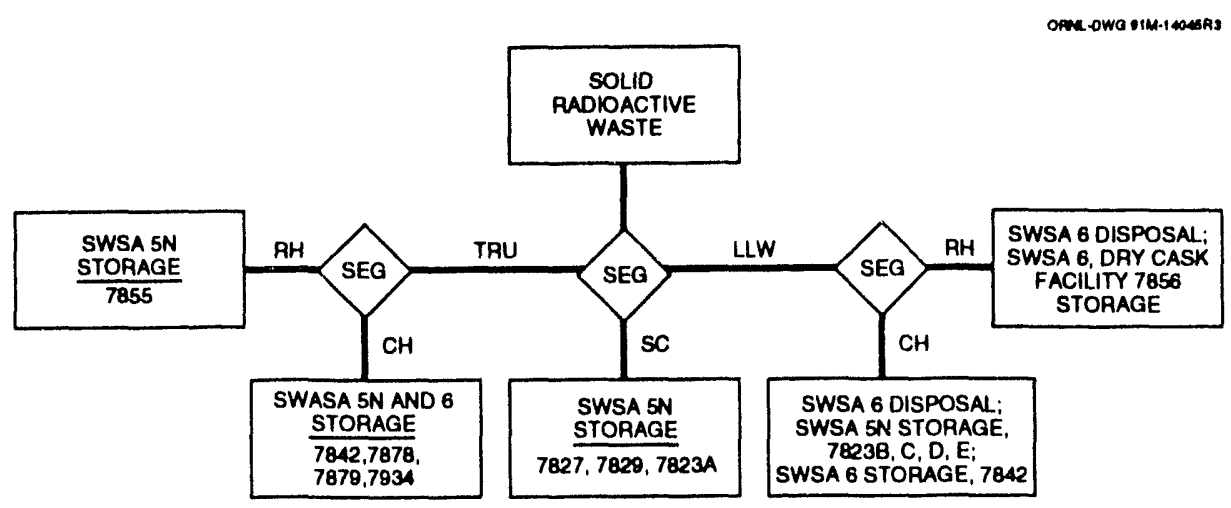

Fig. 3.1. Decision tree for segregation and disposition of solid radioactive waste at Oak Ridge National Laboratory. SWSA-Solid Waste Storage Area.

generic description, and characteristics of the waste and the status of storage, treatment, and disposal facilities for TRU, LLW, and SC waste at ORNL. Figure 3.2 shows the respective location of the radioactive solid waste treatment, storage, and disposal facilities.

\subsubsection{Transuranic Waste}

TRU waste is defined in DOE Order $5820.2 \mathrm{~A}$ as radioactive waste that, without regard to source or form at the end of the institution control period, is contaminated with alpha-emitting TRU radionuclides that have (1) an atomic number $>92$, (2) half-lives $>20$ years, and (3) an assay concentration $>100 \mathrm{nCi} / \mathrm{g}$. Heads of field offices can also determine that other alpha-contaminated waste, peculiar to a specific site, must be managed as TRU waste. Waste contaminated with ${ }^{252} \mathrm{Cf},{ }^{244} \mathrm{Cm}$, and ${ }^{233} \mathrm{U}$ in concentrations $>100 \mathrm{nCi} / \mathrm{g}$ are also handled as TRU waste at ORNL, although they have not been formally declared as such by the U.S. Department of Energy Oak Ridge Operations Office (DOE-ORO). 


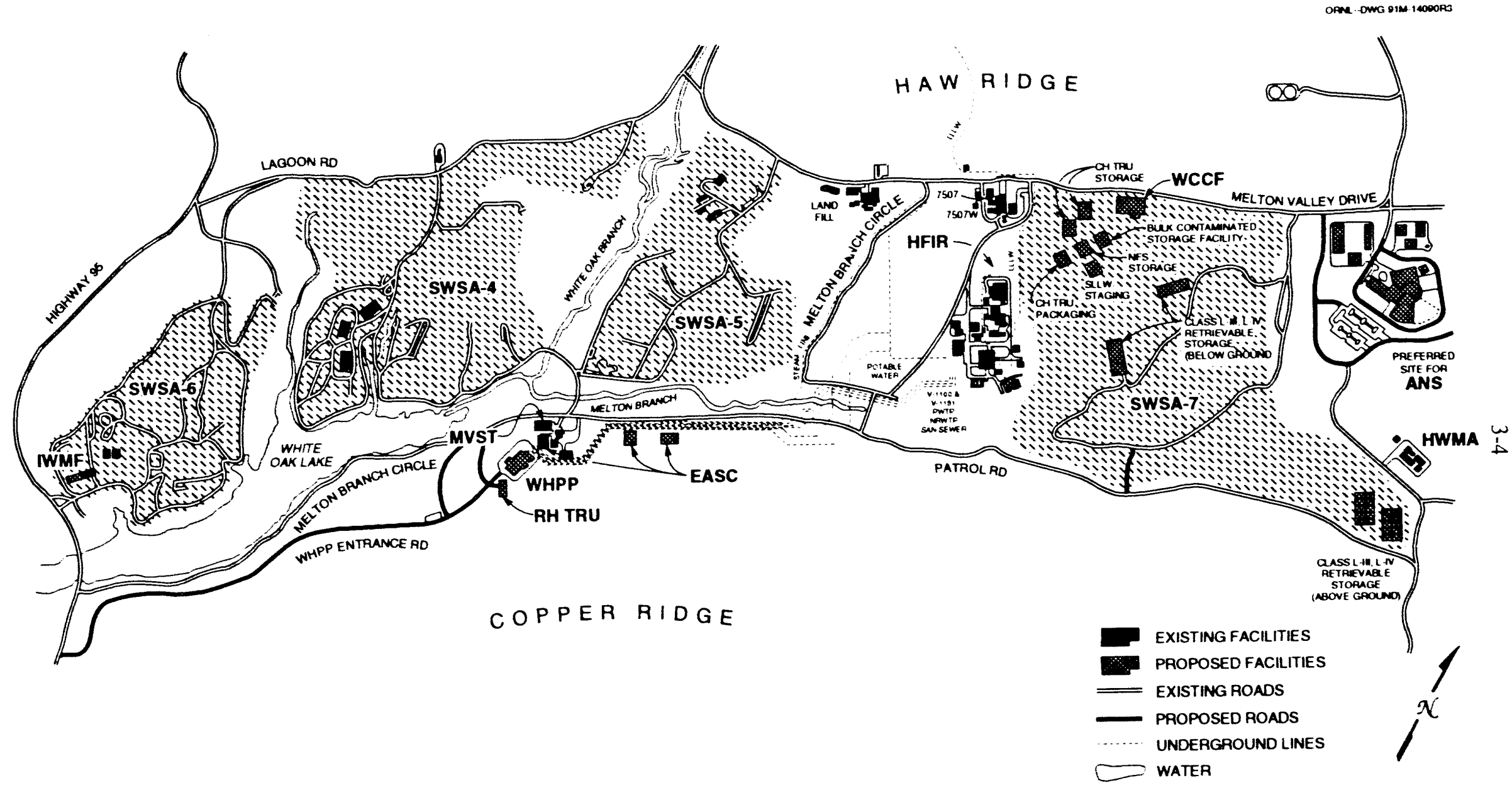

Fig. 32. Location of radioactive solid waste treatment, storage, and disposal facilities. IWMF-Interim Waste Management Facility. SWSA-Solid Waste Storage Area Fig. 3.2. Location of radioaction solign. RH TRU-remote-handled MVST-Melton Valley storage tank. WTIPP-Waste Handle and Crification and Characterization Facility. ANS-Advanced Neutron Source. HWMA-Hazardous Waste Management Area. 
The majority of TRU waste stored at ORNL is from past operations. Currently, ORNL produces only small quantities (e.g., $\sim 20 \mathrm{~m}^{3} /$ year) of newly generated (NG) TRU waste. Most of the existing TRU waste storage facilities at ORNL are located in the north area of solid waste storage area (SWSA) 5 (Fig. 3.3).

\subsubsection{Strategy}

Since 1970 ORNL has been segregating and storing solid alpha-contaminated waste that meets the TRU definition, pending the development of an approved strategy for permanent disposal. The Waste Isolation Pilot Plant (WIPP), located in Carlsbad, New Mexico, is the DOE geologic disposal facility for all TRU waste including ORNL's. TRU waste to be shipped to WIPP must be certified in compliance with WIPP Waste Acceptance Criteria (WAC). Over the past several years ORNL has been developing the procedures for certifying TRU waste for disposal at WIPP.

\section{Disposal at the Waste Isolation Pilot Plant}

According to WIPP WAC, only defense TRU waste will be disposed of at the DOE WIPP, a research and development (R\&D) facility for the safe disposal of TRU wastes resulting from defense activities. It is the planned destination for all certified contact-handled $(\mathrm{CH})$ and remote-handled (RH) TRU waste including mixed TRU waste.

Prior to shipment of waste, WIPP personnel will validate the data package for each waste shipment. On receipt of waste, WIPP personnel will (1) verify the package or assembly identification numbers against the data package, (2) measure the external radiation dose rate of the package and shipping container, (3) verify that contamination levels on the package and shipping container surfaces are within acceptable limits, and (4) review and process all shipping papers and manifests.

The initial 5-year Test Phase for WIPP has recently had a change in strategy. DOE has decided to pursue an expanded laboratory test program using radioactive and hazardous wastes in lieu of underground tests at WIPP using radioactive waste. The redirection of the Test Phase will allow both DOE and the U.S. Environmental Protection Agency (EPA) to address the disposal certification issues more effectively. A 20-year WIPP operating period is planned to follow the successful completion of the Test Phase.

\section{CH TRU waste}

Solid TRU waste is segregated and handled based on the radiological dose rate at the surface of the waste package. CH TRU waste is defined in the WIPP WAC as TRU waste that has a surface dose rate of $\leq 200 \mathrm{mrem} / \mathrm{h}$ and can be handled by direct means without extensive shielding.

Stored CH TRU waste. ORNL has a significant backlog of stored $\mathrm{CH}$ TRU waste, the majority of which is contained in 208-L (55-gal) stainless steel drums; other CH TRU waste packages include stainless steel drums, overpacks, and some large $1.2 \times 1.2 \times 1.5 \mathrm{~m}$ $(4 \times 4 \times 5 \mathrm{ft})$ boxes. $\mathrm{CH}$ TRU waste is stored in below-grade concrete block facilities (Buildings 7826 and 7834) and a metal building (7879) in SWSA 5N. Approximately $616 \mathrm{~m}^{3}\left(22,000 \mathrm{ft}^{3}\right)$ of $\mathrm{CH}$ TRU waste is currently stored at ORNL, which includes about 2800 drums and over 50 boxes. The strategy for stored CH TRU waste is to certify the waste to the WIPP WAC and to store the certified waste at ORNL awaiting shipment to 
ORNL-DWG 89-7065

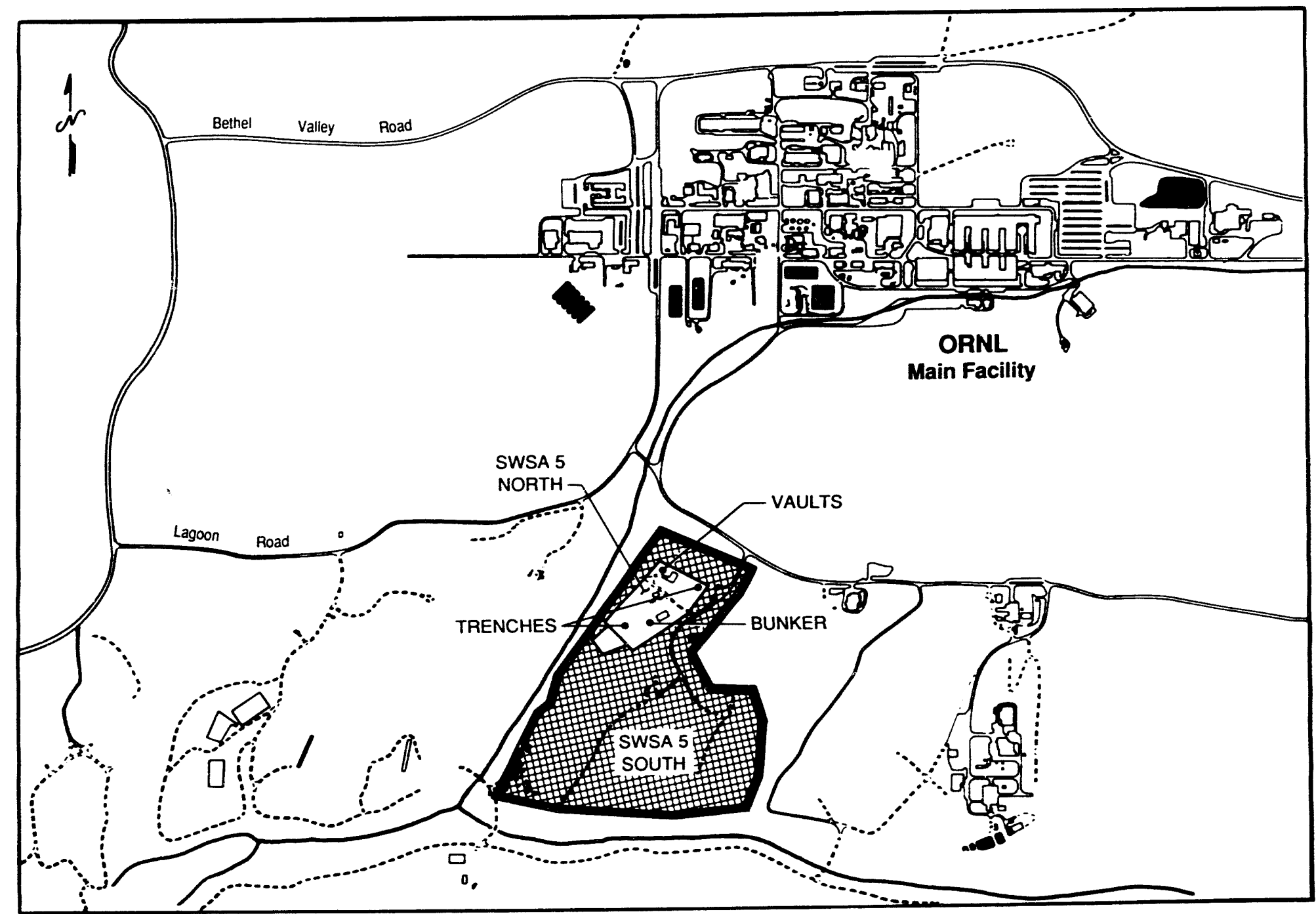

Fig. 3.3. Transuranic waste storage facilities in the north area of Solid Waste Storage Area 5. 
WIPP. Because of recent changes in transportation requirements, most of the $\mathrm{CH}$ TRU waste stored at ORNL will require repackaging.

NG CH TRU waste. Currently, ORNL has only a few sources of NG CH TRU waste. The five ORNL facilities that generate this waste are (1) Building 7920, the Radiochemical Engineering Development Center (REDC); (2) Building 3019, the Radiochemical Development Facility; (3) Building 2026, the High-Radiation-Level Analytical Laboratory (HRLAL); (4) Building 5505, the Transuranium Research Laboratory; and (5) the Isotopes Area of ORNL. Building 7920 is the largest generator, and Buildings 2026 and 5505 generate much less, each producing (in some cases) less than one 208-L (55-gal) drum per year. The estimated annual CH TRU waste generation rate is expected to be 12 to $15 \mathrm{~m}^{3}$ (400 to $500 \mathrm{ft}^{3} /$ year) from normal facility operations. The strategy for NG CH TRU waste is to certify the waste for WIPP disposal. For NG CH TRU waste the generator is responsible for providing a WIPP-certified waste.

Off-site NG CH TRU waste. Currently, ORNL has only one source of NG $\mathrm{CH}$ TRU waste from an off-site generator. Nuclear Fuel Services, Inc., (NFS) has a contract with DOE to ship $155.7 \mathrm{~m}^{3}\left(5500 \mathrm{ft}^{3}\right)$, or 750 drums, to ORNL for interim storage. ORNL received the first shipment of NFS CH TRU waste on November 19, 1992, and has received 260 drums through October 6, 1993.

\section{RH TRU waste}

RH TRU waste is TRU waste that has a surface dose rate of $>200 \mathrm{mrem} / \mathrm{h}$ and must be handled by remote means.

Stored RH TRU waste. The current inventory of RH TRU solid waste stored at ORNL facilities totals 371 waste containers $\left[193 \mathrm{~m}^{3}\left(6830 \mathrm{ft}^{3}\right)\right]$ consisting mainly of concrete casks. RH TRU wastes are stored in SWSA $5 \mathrm{~N}$ in a bunker [97 casks at $137.3 \mathrm{~m}^{3}$ $\left.\left(4850 \mathrm{ft}^{3}\right)\right]$ and 27 trenches [200 casks, 72 boxes, and 2 drums at $\left.56 \mathrm{~m}^{3}\left(1980 \mathrm{ft}^{3}\right)\right]$. Some containers are known to contain lead, mercury, or oil and are considered mixed RH TRU waste. The strategy for stored RH TRU waste is to certify the waste to WIPP WAC by retrieving and processing in the proposed Waste Handling and Packaging Plant (WHPP). The mission of WHPP is retrieval, receipt, characterization, repackaging, certification, and preparation for shipping of TRU waste. SWSA SS contains 108 casks buried in 8 RH TRU trenches immobilized with concrete. RH TRU waste stored in trenches in SWSA 5S is considered nonretrievable.

NG RH TRU waste. The majority of NG RH TRU waste is generated during the normal process operations of Buildings 7920 and 7930. The current generation rate is about six casks per year. Decontamination and decommissioning (D\&D) and remedial action activities will also likely produce RH TRU waste. The strategy for RH TRU waste is to repackage at the proposed WHPP and to certify for WIPP disposal.

\section{TRU sludges}

Various sludges stored at ORNL are contaminated with TRU radionuclides primarily because of past liquid waste operations. These sludges are either residual heels in tanks from past operations or the end product of waste evaporation. TRU-contaminated sludges will be processed and certified as RH TRU waste. Preliminary screening tests for Resource 
Conservation and Recovery Act (RCRA) characteristics conducted in 1990) indicated that all the sludges are potentially RCRA hazardous with respect to mercury and lead, and some are also potentially RCRA hazardous with respect to chromium and cadmium. The full RCRA characterization has not been performed owing to budget limitations.

NG LLLW System sludges. TRU-contaminated sludges currently being generated at ORNL are primarily the result of operations at the REDC (Buildings 7920) and 7930). The existing Liquid Low-Level Waste (LILI.W) System does not currently have provisions for handling TRU-contaminated liquids separate from non-TRU LILLW waste streams. Modification of the LLLLW System to isolate TRU-contaminated liquid waste is currently being studied.

Past LLLW System sludges. About 475,000 L (125,000 gal) of sludge currently stored in the gunite tanks and the Melton Valley storage tanks (MVSTs) is classified as RH TRU waste. The result of waste accumulation from the past 50 years of ORNL waste operations, these sludges are residuals from sluicing operations conducted several years ago when the majority of the gunite tank contents were removed for hydrofracture disposal. Hydrofracture disposal ended in 1984 because of changing regulatory requirements. The sludges in MVST's also resulted partly from this process.

Also, various active and inactive tanks in the ILLLW System contain residual heels contaminated with TRU radionuclides. Characterization of these sludges has been completed for inactive tanks by the Environmental Restoration Program (ERP) and for the active tanks by the Waste Operations Program. The (ORNL strategy for stored TRU sludges involves removal, solidification, and certification to WIPP WAC in the proposed WIIPP.

\section{Buried TRU waste}

Buried TRU waste is defined as TRU waste disposal prior to 1970. Records from that time period indicate several sites where buried TRIJ is known or suspected:

(1) approximately $6200 \mathrm{~m}^{3}\left(218,940 \mathrm{ft}^{3}\right)$ of solid TRU waste commingled with solid lowlevel waste (SILLW) and disposed of in shallow-land burial trenches prior to 1970) (i.e., SWSAS 3, 4, and 5); (2) wastes in pits and trenches from past liquid waste disposal operations (i.e., four pits and three trenches); (3) contaminated soil sites from leaks in the liquid-processing systems (also, some contaminated soils from deteriorated waste packages in the solid waste burial sites) together with inactive contaminated pipclines; and (4) some grout sheets below the New Hydrofracture Facility (NHF) fand possibly below the ()ld Hydrofracture Facility (OHF)/ that contain TRU radionuclides. The final disposition of buried TRU waste is a part of the Remedial Investigation/Feasibility Study currently in progress under the Energy Systems ERP and is not specifically addressed in this plan. Buried TRU waste is not a part of the WIPP mission as currently defined.

\subsubsection{Generic description and characteristics of waste}

\section{CH TRU Waste}

CH TRU waste consists of miscellaneous waste from glove box operations (e.g., paper, glassware, plastic, shoe covers, and wipes), discarded high-efficiency particulate air (HEPA) filters, and discarded equipment (e.g., glove boxes, processing equipment, etc.). The majority of the CH TRU waste has a surface dose rate much less than $200 \mathrm{mrem} / \mathrm{h}$. 
$\mathrm{CH}$ TRU waste is generally contained within polyethylene bags inside 208-L (55-gal) stainless steel drums. Metal paint cans, plastic buckets, and other similar containers are also used to package waste inside the 208-L (55-gal) drums. The flow sheet for handling NG CH TRU waste is shown in Fig. 3.4.

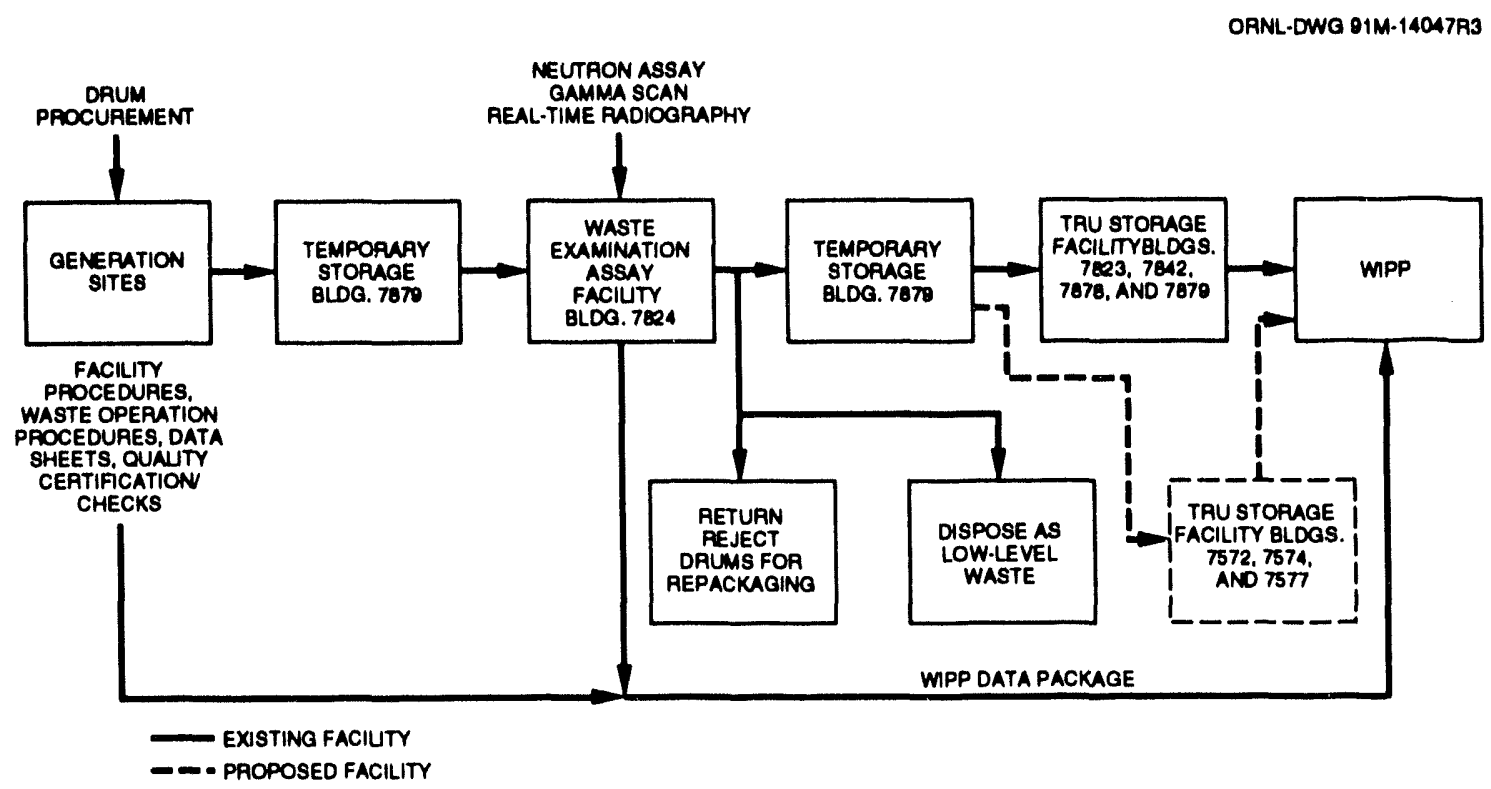

Fig. 3.4. Flow sheet for handling newly generated contact-handled transuranic waste. WIPP-Waste Isolation Pilot Plant.

The current inventory of $\mathrm{CH}$ TRU waste at ORNL is $~ 2800$ 208-L (55-gal) drums placed in storage facilities or awaiting examination in the Waste Examination and Assay Facility (WEAF). Also, a small quantity of $\mathrm{CH}$ TRU waste is stored in 50 large $1.2 \times 1.2 \times 1.8 \mathrm{~m}$ (typically $4 \times 4 \times 6 \mathrm{ft}$ ) boxes but is not restricted to this type package. Of the $\sim 2800$ drums in storage, $\sim 90 \%$ are known or suspected to contain RCRA materials.

\section{RH TRU waste}

Solid RH TRU waste consists primarily of miscellaneous cell waste (e.g., paper, glass, plastic tubing, shoe covers, wiper, etc.), HEPA filters from off-gas cleanup systems, and discarded equipment (e.g., processing racks, vacuum pumps, furnaces). The unshielded individual waste packages within the casks typically have radiation levels that measure between 10 and $2000 \mathrm{rem} / \mathrm{h}$; the majority are below $100 \mathrm{rem} / \mathrm{h}$. RCRA materials in RH TRU waste primarily consist of lead that was used as shielding and limited amounts of mercury from discarded mercury vapor lamps.

RH TRU waste is typically contained in cylindrical concrete casks $1.4 \mathrm{~m}(4.5 \mathrm{ft})$ in diameter by $2.3 \mathrm{~m}(7.5 \mathrm{ft})$ high. Wall thickness of the casks are currently either 15.2 or $30.5 \mathrm{~cm}$ (6 or $12 \mathrm{in}$.) thick, depending on the radiation level of the contents. The majority of the RH TRU wastes inside the concrete casks are also contained inside polyethylene bags. Smaller waste packages such as 11-L (3-gal) plastic buckets, 3.7-L (1-gal) paint cans, and 18.9-L (5-gal) metal cans are packaged within the polyethylene bags. Also 37.8-L (10-gal) 
fiber drums and 114- and 208-L (30- and 55-gal) carbon and steel drums have been used to package waste material before placing the waste in concrete casks. The RH TRU waste currently stored within SWSA 5N at ORNL consists of 97 concrete casks stored in Building 7855 and 200 casks, 72 boxes, and 2 drums stored in trenches $(7802 \mathrm{~N})$.

\section{Sludges}

TRU sludges in storage in the gunite tanks are residual heels fron sluicing operations between 1980 and 1984 when the majority of the gunite tank contents were removed for hydrofracture disposal at the NHF. The sludges in the MVSTs are a result of past hydrofracture disposal and NG LLLW concentrate. These sludges have a relatively high water content and a density of about 1.2 to $1.5 \mathrm{~g} / \mathrm{cm}^{3}$. The surface dose rates of these sludges are generally near $10 \mathrm{rem} / \mathrm{h}$ (unshielded). The sludges potentially exceed RCRA limits for lead, mercury, chromium, and cadmium. After solidification the majority of these sludges will be certified as RH TRU waste. The quantity of RH TRU sludges in the gunite and other inactive tanks and the MVSTs is estimated to be 475,000 L $(125,000 \mathrm{gal})$.

\subsubsection{Waste assay facilities}

WEAF currently serves as the inspection facility for the examination of $\mathrm{CH}$ TRU waste and SLLW. WEAF is utilized as a verification facility for data provided by the waste generators. A new assay facility that would expand the throughput and efficiency of WEAF is planned as a 1995 line item (LI) project.

\section{CH TRU waste}

The proposed treatment facility for CH TRU waste is WHPP. WHPP is discussed under the RH TRU subsection that follows. WEAF and the proposed Central Certification Facility are described in the following paragraphs.

Waste Examination and Assay Facility. WEAF (Building 7824), located in SWSA $5 \mathrm{~N}$, houses equipment for nondestructive examination (NDE) and nondestructive assay (NDA) of CH TRU and SLLW as well as personnel offices and a control room. NDE and NDA equipment located in WEAF includes the real-time radiography (RTR) unit, the Passive/Active Neutron Assay System, and the Segmented Gamma Scanner.

Environmental monitoring. Constant air monitors operate to detect alpha and beta/gamma emissions. An alarm sounds if a preset level of emissions is detected.

Permitting status. Although WEAF is not a storage, treatment, or disposal facility, it was included in ORNL's RCRA Part A permit application at the request of the State.

Facility status. WEAF is currently operational.

Central Verification Facility. Design Criteria are being prepared for the Central Verification Facility to address the needs of the Oak Ridge Reservation (ORR). These criteria are being expanded from those developed for the WCCF. This facility would replace the WCCF Project for NDA and NDE of CH TRU and SLLW to verify that the WAC for storage and disposal of these wastes have been met. It would serve the NDA and NDE needs of the entire ORR and would consolidate the scope of the WCCF and other proposed 
NDA and NDE facilities at other ORR sites. The facility would house the existing NDA and NDE equipment for drummed and boxed waste currently located at WEAF and other locations around the ORR, and would provide space for needed upgrades to current equipment.

Environmental monitoring. The facility would be equipped to meet applicable environmental monitoring requirements.

Permitting status. The facility would probably be permitted to meet RCRA storage requirements similar to WEAF. An Environmental Assessment (EA) would be prepared to meet National Environmental Policy Act (NEPA) requirements.

Facility status. The Centralized Verification Facility is in the planning stage, and no location has been selected. A Systems Requirements Document (SRD) and a siting study are planned for FY 1994. Documentation already prepared for the WCCF and other previously proposed NDA and NDE facilities will be used while preparing the SRD. This facility is scheduled to be an FY $1995 \mathrm{LI}$ assuming the SRD is completed and funding is available. The estimated project cost is $\$ 40 \mathrm{M}$.

\subsubsection{Treatment facilities}

No facilities exist at ORNL for the treatment of $\mathrm{CH}$ or RH TRU waste. WHPP is the proposed facility for processing the stored solid $\mathrm{CH}$ and RH TRU waste and RH TRU sludges.

Waste Handling and Packaging Plant. WHPP is proposed for processing stored solid RH TRU waste and RH TRU sludges. WHPP will be designed for mobilizing, transferring, and solidifying sludges stored in MVSTs, processing solid RH TRU waste, and certifying and packaging RH and CH TRU waste for shipment to WIPP. WHPP will be capable of receiving casks of different sizes, off-site wastes, and liquid and sludge from ORNL's liquid waste storage tanks. The main processing cell will be remotely operated and remotely maintained and will have the capacity for unpackaging, characterizing, volume reducing, assaying, repackaging, and certifying the waste to meet the WIPP WAC. Whether WIPP is approved as a disposal site for TRU waste or not, WHPP is still required. Most of the TRU wastes in storage at ORNL are land disposal restriction (LDR) wastes and must be removed from the inactive liquid waste storage tanks to meet the requirements of the Federal Facilities Compliance Agreement (FFCA). Without WHPP, DOE will be unable to meet these requirements.

A conceptual cutaway of WHPP showing equipment layout and process flow is shown in Fig. 3.5. The proposed site of WHPP, showing its relationship with the main ORNL Complex and other TRU waste facilities, is depicted in Fig. 3.6.

Environmental monitoring. The facility will be equipped to meet current and anticipated environmental monitoring requirements.

Permitting status. An Environmental Impact Statement will be submitted to meet NEPA requirements, and WHPP will be a RCRA-permitted facility. 


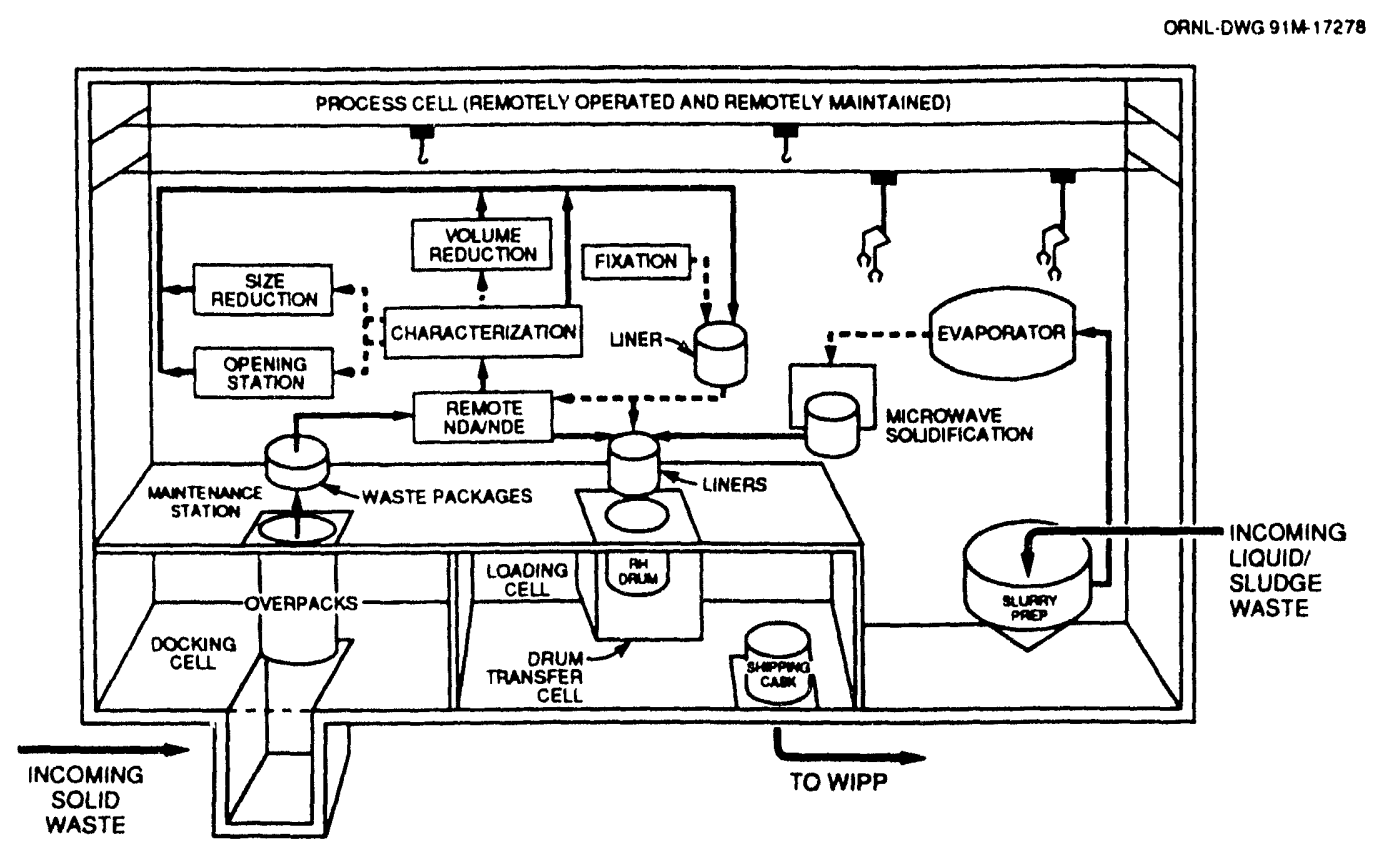

Fig. 3.5. Conceptual Waste Handling and Packaging Plant cutaway. WIPP-Waste Isolation Pilot Plant.

Facility status. ORNL will seek funding for WHPP as an FY 1997 LI project. Preliminary cost estimates for WHPP indicate a total estimated cost (TEC) of $\$ 300 \mathrm{M}$ as a 1997 LI.

\subsubsection{Storage facilities}

The locations of solid TRU waste storage facilities and trenches in the north area of SWSA 5 are shown in Fig. 3.7. Sludges are stored in MVSTs and in eleven or more of the inactive tanks. The inactive tanks containing TRU sludges are located in the main ORNL Complex and at the OHF. In addition, unknown quantities of sludge may be stored in various active collection tanks in the LLLW System. Most of these active tanks are located primarily in the main ORNL Complex.

\section{CH TRU waste}

$\mathrm{CH}$ TRU waste is currently stored in Buildings 7826 and 7834. Building 7879 is a staging facility for drummed waste and for the temporary storage of boxed waste. Two existing LLW storage facilities, Buildings 7842 and 7878 , will be upgraded and permitted for $\mathrm{CH}$ TRU storage. Two new $\mathrm{CH}$ TRU storage facilities are planned.

Buildings 7826 and 7834. Current facilities for storage of drummed 208-L (55-gal) CH TRU waste consist of two nearly identical facilities (Buildings 7826 and 7834). Building 7826, the oldest of the CH TRU storage facilities, is a concrete block structure built approximately $85 \%$ below-grade. The facility has 24 storage compartments or cells, each of which will hold 64 208-L (55-gal) drums for a total capacity of 1536 drums. The drums are stacked four layers high in each storage compartment. 


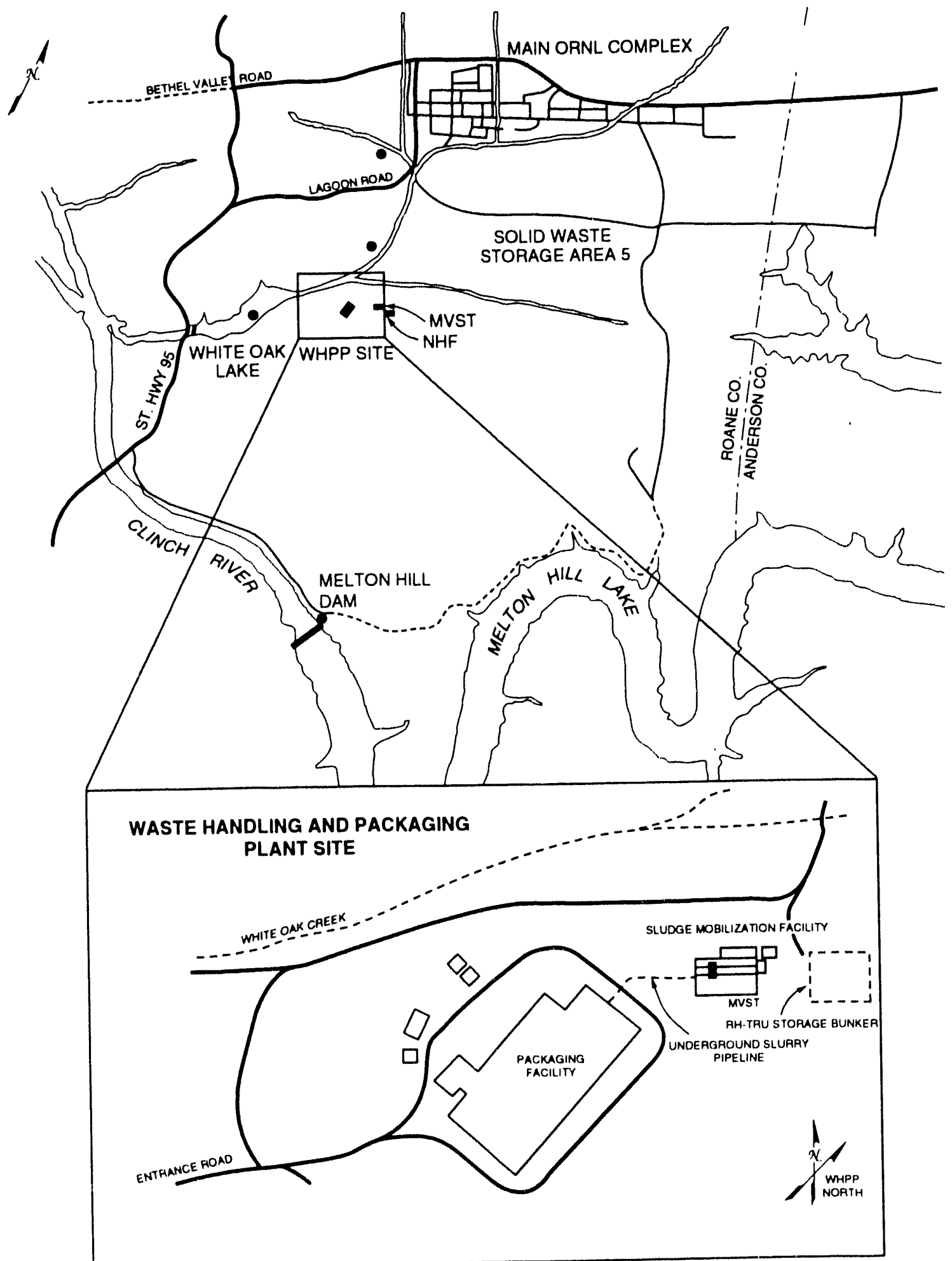

Fig, 3.6. Waste Handling and Packaging Plant site and its relationship to main Oak Ridge National Laboratory Complex and other transuranic waste facilities. MVST--Melton Valley storage tank, NHF-New Hydrofracture Facility. 


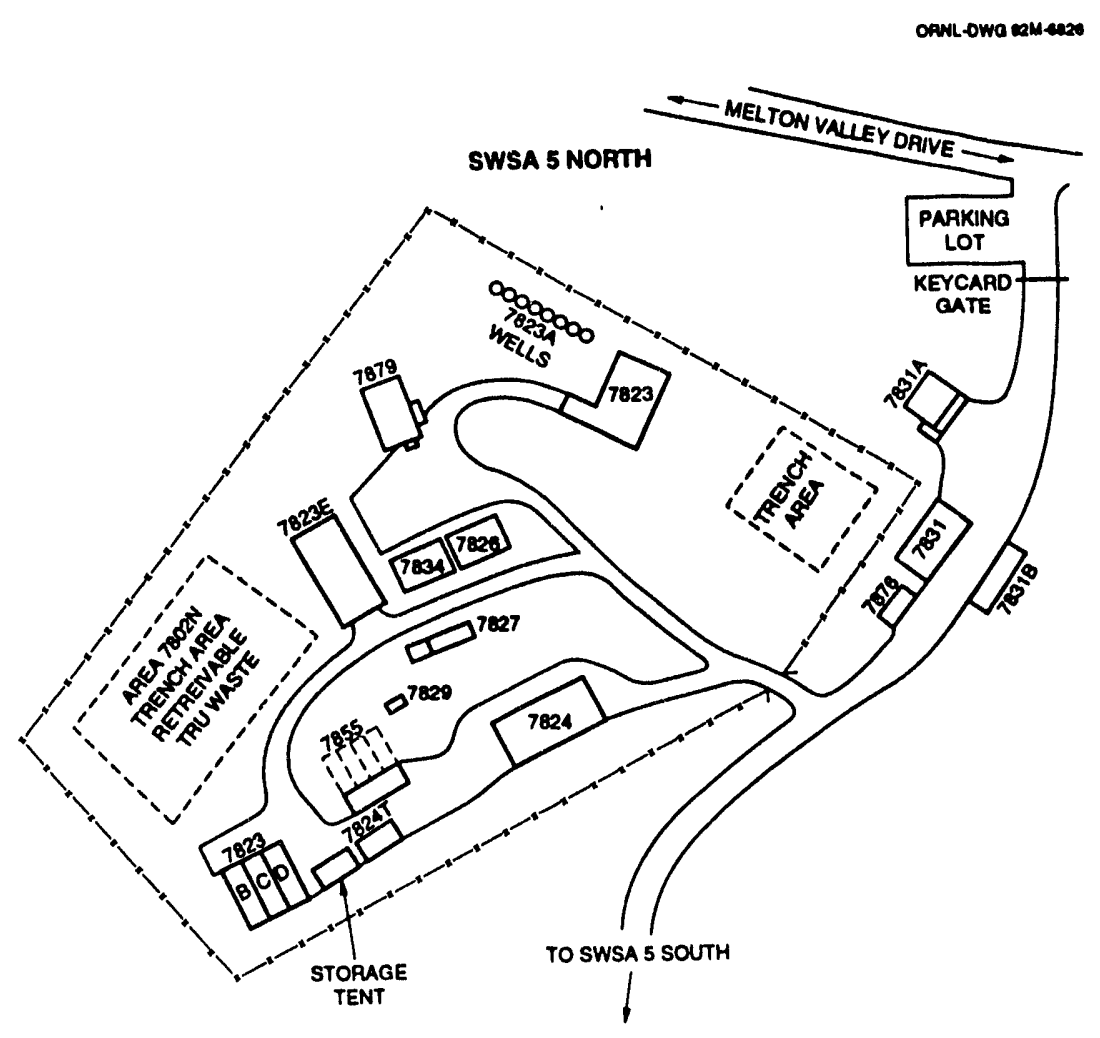

Fig. 3.7. Locations of transuranic waste storage and disposal facilities in the north area of Solid Waste Storage Area 5.

Building 7834 is very similar except the 24 storage cells will each hold 80 drums (when stacked five layers high) for a total capacity of 1920 drums. Also, this newer facility has removable concrete roof plugs instead of the sheet metal roof covers used in the 7826 facility.

Environmental monitoring. Monitoring of Building 7834 and 7826 is primarily conducted through the sampling of sumps located in each storage compartment. Each compartment contains a floor drain and a sump that empties to an external catch basin. The catch basin is sampled if liquid is discovered in it during routine inspections.

Permitting status. The facilities are currently operating on a RCRA interim status permit pending completion of closure of these facilities.

Facility status. Closure of these facilities began in November 1992.

Building 7842. Building 7842 is a prefabricated metal building $12 \times 24 \times 6 \mathrm{~m}$ $(40 \times 80 \times 20 \mathrm{ft})$ mounted on a reinforced concrete pad; it has a corrugated metal roof. Access to the building is provided by two garage doors in the north perimeter wall $[24 \mathrm{~m}$ $(80 \mathrm{ft})]$, two garage doors in the east wall $[12 \mathrm{~m}(40 \mathrm{ft})]$, and a personnel access door on each north and west wall. The building is equipped with electricity and telephone lines. It will be used for storage of mixed CH TRU waste in drums and boxes that are $\leq 200 \mathrm{mrem} / \mathrm{h}$ at the container surface. The storage capacity is $900299-\mathrm{L}$ (79-gal) drums. 
Environmental monitoring. The facility will be upgraded to meet all applicable environmental and personnel monitoring requirements as specified in RCRA, DOE orders, and all other applicable regulations.

Permitting status. Building 7842 will be added to the ORNL Part A permit application in FY 1994. The facility will be RCRA Part B permitted for storage of mixed $\mathrm{CH}$ TRU waste.

Facility status. At present, the facility is used for storage of LLW. All LLW will be removed to allow some facility upgrade work to be completed. Storage of mixed CH TRU waste is estimated to begin in the second quarter of FY 1994. The current inventory is $1074 \times 4 \times 6 \mathrm{ft}$ boxes [291 $\left.\mathrm{m}^{3}\left(10,272 \mathrm{ft}^{3}\right)\right]$ of LLW.

Building 7878. Building 7878 is a prefabricated metal building $12 \times 24 \mathrm{~m}$ $(40 \times 80 \mathrm{ft})\left[298 \mathrm{~m}^{2}\left(3200 \mathrm{ft}^{2}\right)\right]$ constructed on a concrete slab. The building has a $3.7-\mathrm{m}-$ wide (12-ft) roll-up door and personnel entrance doors on each end. The building is equipped with electric utilities for lights and ventilation fans. The building will provide storage for mixed $\mathrm{CH}$ TRU waste that is $\leq 200 \mathrm{mrem} / \mathrm{h}$ at the container surface. The storage capacity is $960208-\mathrm{L}$ (55-gal) drums.

Environmental monitoring. The facility meets all applicable environmental and personnel monitoring requirements as specified in RCRA, DOE orders, and all other applicable storage regulations.

Permitting status. Building 7878 was added to ORNL's Part A permit application in February 1993. The facility will be added to ORNL's Part B permit application for storage of mixed $\mathrm{CH}$ TRU waste.

Facility status. The facility was used for storage of LLW in drums and boxes. All LLW was removed from the facility. The facility was upgraded to meet RCRA requirements for storage of mixed CH TRU waste in drums and boxes. Storage of mixed CH TRU waste within Building 7878 is expected to begin in the first quarter of FY 1994.

Building 7879. Building 7879 is a metal Butler-type building of $15 \times 25 \mathrm{~m}$ $(50 \times 83 \mathrm{ft})$ used for storage of TRU/SLL.W. The facility has a sealed concrete floor with curbing to meet RCRA requirements. The facility is able to store more than 1000 drums in a configuration that allows RCRA inspection.

Environmental monitoring. The facility was designed and equipped to meet all applicable environmental and personnel monitoring requirements as specified in RCRA, DOE orders, and other applicable regulations.

Permitting status. The facility is listed on ORNL's RCRA Part A and Part B permit applications.

Facility status. The facility began operation in early 1991.

Buildings 7572 and 7577. Two new $\mathrm{CH}$ TRU waste storage facilities are planned to replace existing $\mathrm{CH}$ TRU storage facilities, Buildings 7826 and 7834 . The new facilities will be aboveground metal Butler-type buildings having sealed concrete floors and curbing to 
meet RCRA and DOE requirements. The facilities will have storage capacities of about 3000 208-L (55-gal) drums and will be located in the SWSA 7 area.

Environmental monitoring. The facilities will be designed to meet all applicable environmental and personnel monitoring requirements as specified in RCRA, DOE orders, and all other applicable regulations.

Permitting status. The facilities are listed on ORNL's current RCRA Part A and Part B permit applications. An EA has been submitted to DOE to meet NEPA requirements.

Facility status. Building 7572 is planned as a 1990 general plant project (GPP) with a TEC of $\$ 1.1 \mathrm{M}$. Design was completed and certified for construction in June 1993. Construction will begin on completion of the NEPA process. The proposed construction schedule begins in November 1993 with completion in October 1994. Building 7577 is planned as an FY 1996 GPP.

Building 7574. A new waste storage facility is planned for long-term storage of $154 \mathrm{~m}^{3}\left(5500 \mathrm{ft}^{3}\right.$ ) (about 750 drums) of $\mathrm{CH}$ TRU waste from NFS. The waste will be temporarily stored in the new TRU/SLLW Staging Facility, Building 7879. Building 7574 will be nearly identical to Building 7879 and will be located in the SWSA 7 area.

Environmental monitoring. The facility will be designed to meet all applicable environmental and personnel monitoring requirements as specified in RCRA, DOE orders, and all other applicable regulations.

Permitting status. The facility is included in the ORNL RCRA Part A and Part B permit applications. A revised EA was submitted to DOE to meet NEPA requirements.

Facility status. This facility is planned as a 1992 GPP. A Finding of No Significant Impact was issued in October 1992. Construction is expected to be complete in July 1994.

\section{RH TRU waste}

RH TRU waste at ORNL is currently stored in an earth-sheltered building (7855) and in trenches in SWSA $5 \mathrm{~N}$. The locations of the RH TRU waste storage facility and the trenches containing stored RH TRU wastes are shown in Figs. 3.2 and 3.7. A new RH TRU waste storage facility is planned near the NHF. The facilities used for the storage of the RH TRU sludges are discussed under LLLW (Subsect. 3.2.2).

Building 7855. The storage bunker currently used at ORNL for storing RH TRU waste in concrete casks is Building 7855, a one-story, largely underground concrete block structure on a reinforced concrete slab with a reinforced concrete roof. The structure is a

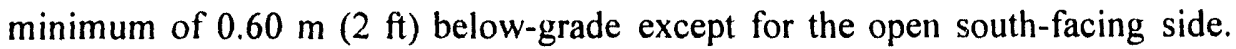

The structure is divided into four bays by concrete block walls that extend from the floor to the roof. Each bay of the facility is approximately $4.6 \times 13.7 \times 3.04 \mathrm{~m}$ $(15 \times 45 \times 10 \mathrm{ft})$ and has adequate area to hold 27 concrete casks, giving a total capacity for the facility of 108 casks. When a bay is filled, a concrete block wall is constructed across the bay to provide shielding and to close off the bay. When retrieval becomes necessary, the walls will be removed, and the concrete casks will be retrieved. 
Environmental monitoring. Each bay contains a sump and a drain system for collection of groundwater or any leakage from the stored casks. The collection system is sampled if liquid is discovered in it during routine operations. Pipe sleeves penetrate various locations in the roof to allow for air sampling.

Permitting status. The facility operated under a RCRA Part B permit from October 1990 through June 1991. Per the consent order signed by DOE in June 1991, the unit reverted back to interim status. It is included in the Part B permit for TRU units.

Facility status. The facility has been in operation since 1979 and will continue to be used until the WHPP becomes operational and the inventory of the RH TRU waste stored in the facility is retrieved for repackaging at WHPP.

Building 7883. The RH TRU Waste Storage Bunker Project is a 1989 GPP to provide additional storage capacity of RH TRU waste in concrete casks. The facility will be an earth-sheltered structure similar to the configuration of Building 7855. A front elevation view of a typical RH TRU storage bunker is shown in Fig. 3.8. The bunker will have four bays and a storage capacity of 108 casks; each bay will hold 27 casks. The bunker will be located near the MVST.

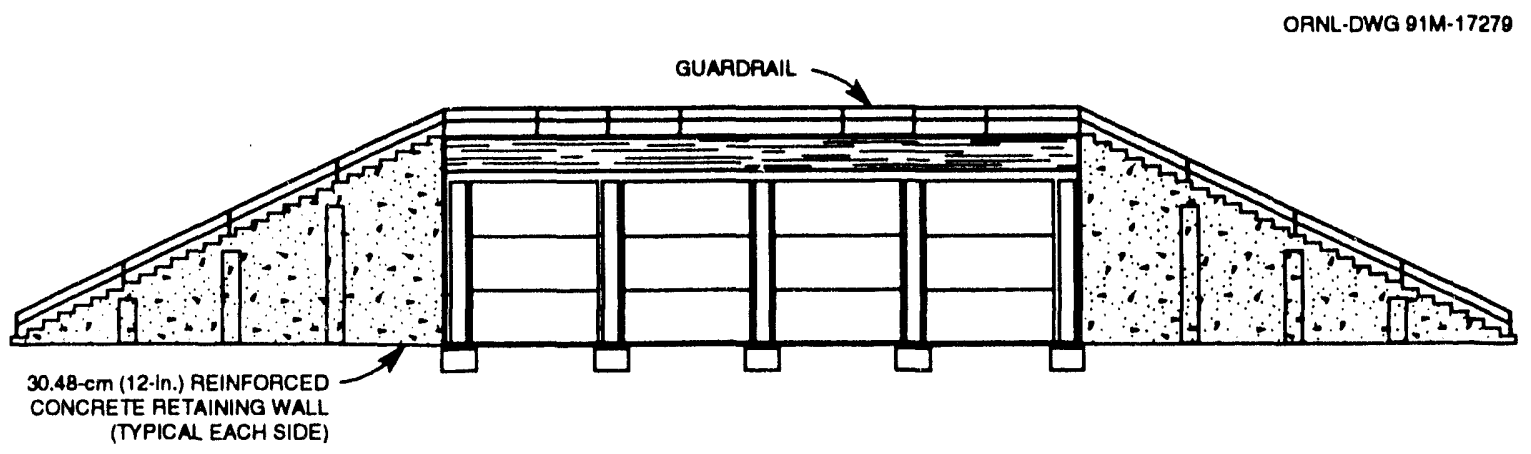

Fig. 3.8. Front elevation view of a typical remote-handied transuranic storage bunker (Building 7883).

Environmental monitoring. The facility will be designed to meet RCRA permitting requirements and all other environmental and personnel monitoring requirements as specified in DOE orders and all other applicable regulations.

Permitting status. The facility is listed on the RCRA Part B permit application. An EA was submitted to meet NEPA requirements.

Facility status. Design was completed and certified for construction in July 1993. A bid package is being prepared. Delay in receipt of NEPA approval has suspended the completion schedule.

RH TRU in burial trenches. Twenty-seven trenches in SWSA 5N were used from 1970 to 1979 to store 274 waste containers. The estimated quantity of waste buried in this manner is 200 concrete casks, 72 boxes, and 2 drums. The location of these trenches in SWSA $5 \mathrm{~N}$ is shown in Fig. 3.7. Conducted under the Active Sites Environmental 
Monitoring Program, monitoring of the trenches focuses on groundwater monitoring wells, seeps, and samples from small tributaries. These trenches have not been used for interim storage since the RH TRU bunker (Building 7855) became available in 1979. An FY 1996 LI project has been proposed to provide storage for this waste after Building 7855 has reached its storage capacity. The permitting status of the buried TRU waste in the trenches in SWSA $5 \mathrm{~N}$ is currently under review by the EPA, the state of Tennessee, and DOE.

\subsubsection{Disposal Facilities}

TRU waste from ORNL will be disposed at WIPP during a 20-year Disposal Phase following a multiyear Test Phase. The initial 5-year Test Phase for WIPP, which called for underground bin and alcove tests using radioactive waste, is to be replaced by an enhanced laboratory test program using simulated waste as well as actual waste (TRU and/or RCRA constituents). The revised test program plan is scheduled to be submitted to the EPA and others for review and comment by December 31, 1993. The revised test program is intended to provide data more relevant to a Certificate of Compliance with final disposal requirements, which would accelerate the disposal decision at WIPP. If results of this decision are favorable, permanent disposal of TRU waste may occur earlier than scheduled under the previous Test Phase strategy.

\subsubsection{Status of support systems}

\section{Training}

TRU waste generator training is required for all personnel involved in loading, handling, and examining TRU waste packages prior to being authorized to perform their duties. Specific guidance is given to certifying TRU waste and preparation for CH TRU waste destined for WIPP. The training is offered on a monthly basis. The new generator training program presents TRU requirements in tandem with SLLW requirements. Generators of TRU waste are required to attend both SLLW and TRU waste generator training. All personnel who package TRU waste at ORNL are required to complete this course satisfactorily every 2 years, which includes attending the training program and passing a written examination. RCRA training is required annually for personnel involved in handling TRU mixed wastes at ORNL (Subsect. 4.1.6.1).

\section{Certification}

The first TRU waste certification plan at ORNL was developed in May 1984. In May 1985 the WIPP Waste Acceptance Criteria Certification Committee (WACCC) audited the ORNL TRU Waste Certification Program. Several items found to be inadequate or deficient resulted in a significant effort at ORNL to correct the problems. In September 1985 a revised certification plan was submitted to the WIPP WACCC.

An internal quality assurance (QA) audit of ORNL TRU waste generators and the Waste Certification Program was conducted during December 1990; no major program deficiencies were identified. Subsequently, the WIPP WACCC audited the ORNL TRU Waste Certification Program in March 1992. That audit resulted in the identification of two findings: (1) REDC standard operating procedures had not completed the entire review cycle and therefore were not controlled and (2) Health Physics was using a generic standard operating procedure for a field instrument. Both findings have been closed pending verification by WIPP. 


\section{Database management}

A computer database is currently being used at ORNL to monitor the storage and disposal of radioactive wastes. The Solid Waste Information Management System (SWIMS) is the database for SLLW and TRU solid radioactive waste.

\subsubsection{Update of implementation summary table}

Appendix A provides an update to the original implementation summary for management of transuranic waste that was provided in the Oak Ridge National Laboratory Implementation Plan for DOE Order 5820.2A. The format in Appendix A duplicates the format of the requirements for the management of TRU waste contained in DOE Order 5820.2A. Many activities planned for achieving compliance with the order are applicable to more than one requirement. To avoid duplication of costs for achieving compliance, cross-referencing between requirements is used extensively.

The most significant revision to the table occurs under requirement $b(1)$. The TEC for the WHPP has been increased from $\$ 285 \mathrm{M}$ to $\$ 300 \mathrm{M}$, and the project date has been moved from FY 1996 to FY 1997. The increase in TEC is the escalation attributable to the time delay of the project. Other revisions to the table are very minor and reflect, primarily, points of edification.

\subsubsection{Line item and general plant projects}

A listing of proposed $\mathrm{LI}$ and GPPs for TRU facilities at ORNL is provided in Table 3.1. This table indicates the project title, TEC, and the respective fiscal year for funding.

Table 3.1. Line item and general plant projects for transuranic waste facilities at Oak Ridge National Laboratory

\begin{tabular}{|c|c|c|}
\hline Title & $\begin{array}{c}\text { TH:C" } \\
(\$ \times 1,000) \\
\end{array}$ & $\begin{array}{l}\text { liscal } \\
\text { year }\end{array}$ \\
\hline \multicolumn{3}{|l|}{ Line item projects } \\
\hline Central Verification Facility & $4(1,0)(0)$ & 1995 \\
\hline Retrievable Cask Storage Bunker & 6,000 & 1906 \\
\hline Waste Handling and Packaging Plant & 300,000 & 1997 \\
\hline \multicolumn{3}{|l|}{ General plant projects } \\
\hline $\begin{array}{l}\text { Remote-Ilandled Transuranic Waste Storage Bunker } \\
\text { (Building 7883) }\end{array}$ & $9(14$ & 1989 \\
\hline Contact-1landled Transuranic Storage Facility (Building 7572) & $1,(150)$ & 1990 \\
\hline Waste Lxamination and Assay Facility upgrade (Building 7824) & 1,070 & 1990 \\
\hline $\begin{array}{l}\text { Nuclear Fuel Services, Inc., Waste Storage Facility } \\
\text { (Building 7574) }\end{array}$ & 1,100 & 1992 \\
\hline Transuranic Waste Storage Iacility (Building 7577) & 1,100 & 1996 \\
\hline
\end{tabular}

rTotal estimated cost. 


\subsubsection{Solid Low-Level Waste}

SLLW is radioactive waste not classified as HLW, TRU waste, spent nuclear fuel, or by-product material specified as uranium or thorium mill tailings and waste, as defined by DOE Order 5820.2A. Test specimens of fissionable material, irradiated for R\&D only, may be classified as SLLW provided the concentration of TRU radionuclides is $<100 \mathrm{nCi} / \mathrm{g}$. Small volumes of waste containing NARM may also be managed as SLLW in accordance with the DOE policy in Chap. IV of the order.

\subsubsection{Strategy}

Storage, treatment, and disposal of SLLW generated by ORNL facilities is crucial to their continued operation. Space remaining at current ORNL SLLW storage and disposal facilities is extremely limited. ORNL began phasing out below-grade disposal in SWSA 6 in 1992. The suspect waste landfill, high-range wells, and fissile wells were closed for disposal in December 1992. The biological trenches were closed for (1) contaminated animal wastes in December 1992 and (2) all other contaminated biological wastes on April 1, 1993. The remaining below-grade disposal units (i.e., asbestos silos, low-range silos, and high-range silos) may be closed by the end of 1993 depending on the results of the SWSA 6 Performance Assessment (PA) and the revised closure schedule for Waste Area Group (WAG) 6. Beginning in January 1994, SLLW may be disposed only in the above-grade tumulus Interim Waste Management Facility (IWMF). The number of years of operation remaining in the IWMF depends on future waste generation rates, generator waste segregation and minimization, and waste volume reduction efforts.

The Waste Management and Remedial Action Division (WMRAD) strategy for SLLW is to continue disposal of wastes in the operating SWSA 6 disposal units that meet the radiological performance objectives of DOE Order 5820.2A. Waste materials acceptable for disposal (i.e., PA-acceptable) will be determined by the SWSA 6 PA scheduled for submission to DOE for approval on December 15, 1993. Waste materials not suitable for disp.sal (i.e., PA-limiting) will be stored until a DOE regional or national disposal facility becomes available for disposal of PA-limiting waste. In general, most CH SLLW will be PA-acceptable, and RH SLLW will be PA-limiting. The management strategy for each SLLW stream is summarized in the subsections that follow. Figure 3.9 provides the anticipated schedule and expected duration of the storage, treatment, and disposal facilities for managing ORNL's SLLW.

\section{Contact-handled solid low-level waste}

The current strategy for managing $\mathrm{CH}$ SLLW is to ship the waste to an off-site commercial treatment facility for volume reduction. OrNL has a general services contract with Scientific Ecology Group (SEG) for supercompacting, incineration, or smelting of $\mathrm{CH}$ SLLW. All ORNL wastes processed at SEG, except for metals processed by metal melting, will be returned to the ORR for storage or disposal. Biological wastes, very low activity wastes, and compactible and noncompactible wastes will be processed by SEG. Noncombustible and noncompactible wastes such as Process Waste Treatment Plant (PWTP) sludges and ER/D\&D soils and demolition debris will be stored at ORNL waste storage facilities. Wastes that do not meet the WAC of the operating disposal units will be stored pending development of new ORR disposal facilities planned by the Energy Systems Waste Management Organization (ESWMO) or access becomes available at a DOE regional or national disposal facility. 
ORNL-DWG 91M-14679A6

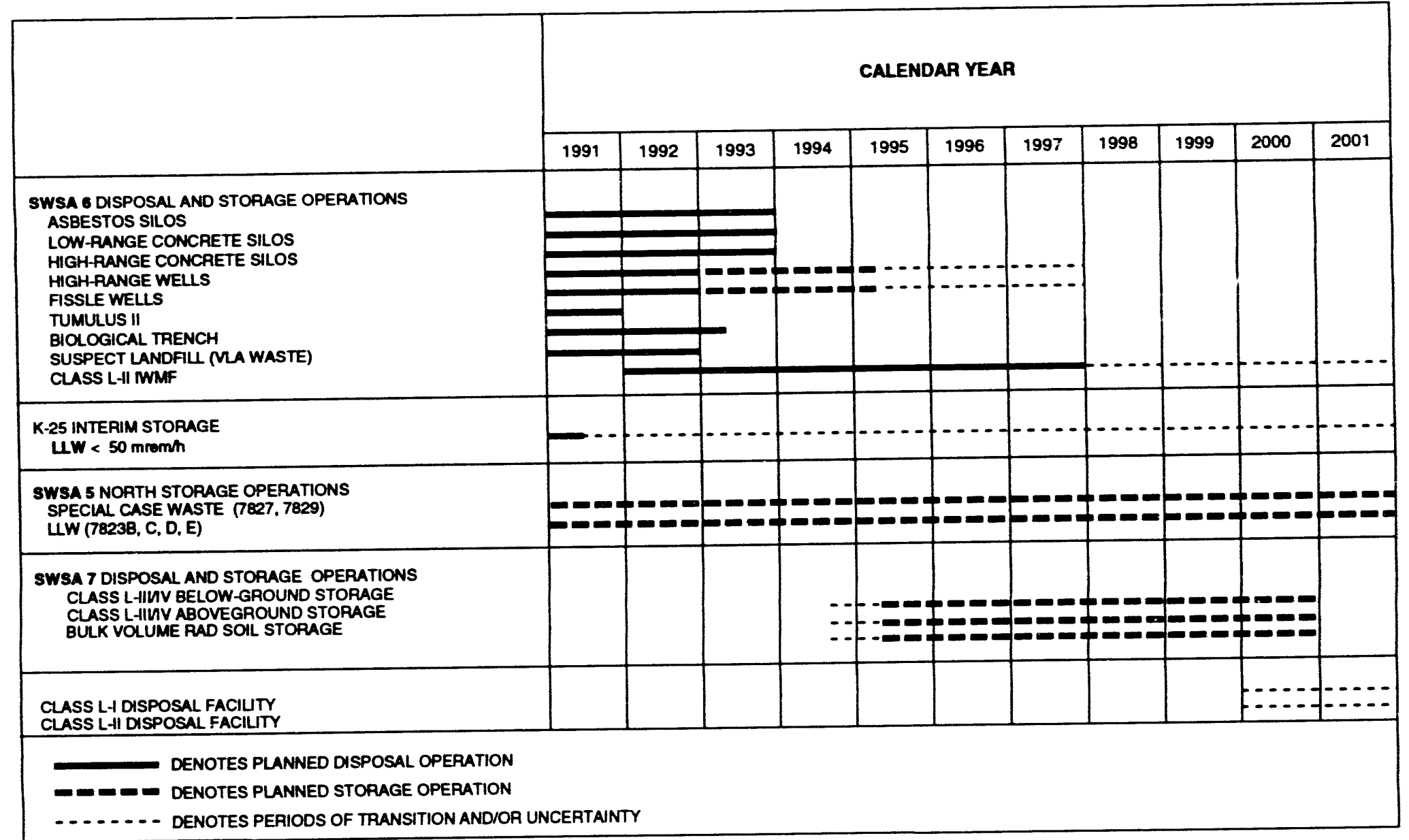

Fig. 3.9. Projected availability of low-level waste storage and disposal facilities. SWSA-Solid Waste Storage Area: LLW-low-level waste; VLA-very low activity; IWMF-Interim Waste Management Facility. 


\section{Remote-handled solid low-level waste}

ORNL is also storing PA-limited RH SLLW. NG RH SLLW is stored in above- and below-grade storage facilities. Below-grade storage wells in SWSA $5 \mathrm{~N}$ are used to store SC waste (i.e., irradiated fuel and fuel debris, irradiated hardware, and sealed, radiation sources). Below-grade storage wells in SWSA 6 will be used to store RH SLLW and fissile waste. An above-grade concrete cask storage area near the former ORNL NHF is used to store solidified liquid waste supernatants from the LLLW concentrate storage tanks. RH SLLW that is too large to fit in a storage well will also be stored in the concrete cask storage area. A new above-grade storage area for solidified liquid waste will be located in SWSA 6. New above- and below-grade storage facilities in SWSA 7 are to begin operation in FY 1995. RH SLLW will be stored in these facilities until a DOE regional or national disposal site becomes available to dispose of PA-limiting wastes.

\subsubsection{Generic description and characteristics of waste}

Approximately $2124 \mathrm{~m}^{3} /$ year $\left(\sim 75,000 \mathrm{ft}^{3} /\right.$ year $)$ of SLLW is routinely handled at ORNL. LLW is classified as either $\mathrm{CH}$ or $\mathrm{RH}$ based on the radiation dose rate at the surface of the waste package. CH SLLW accounts for $93 \%$ of the volume but only $1.5 \%$ of the activity. ORNL also manages some special categories of SLLW such as fissile, asbestos, biological, very low activity waste, and SC waste. Table 3.2 lists the various categories of SLLW at ORNL.

Table 3.2. Current solid low-level waste (SLLW) segregation categories

\begin{tabular}{ll}
\multicolumn{1}{c}{ Waste type } & \multicolumn{1}{c}{ Description } \\
\hline Contact-handled & SLLW $\leq 200 \mathrm{mrem} / \mathrm{h}$ \\
& - compactible \\
& noncompactible \\
Remote-handled & SLLW $>200 \mathrm{mrem} / \mathrm{h}$ \\
& - hot cell debris \\
& - irradiated hardware \\
& - solidified liquids \\
& - ion exchange resins \\
Fissile & sealed sources \\
Biological & SLLW with a ${ }^{235} \mathrm{U}$ equivalent $\geq 1 \mathrm{~g}$ or $\geq 1$ g/ft \\
Asbestos & Radioactively contaminated biological material \\
Very low activity & Radioactively contaminated asbestos material \\
& SLLW with no measurable external contamination but with \\
the potential for inaccessible areas of internal contamination & SLLW that does not fit into typical waste management plans \\
Special case & and requires special storage/disposal schemes
\end{tabular}

\section{Contact-handled low-level waste}

CH SLLW (low-range) is waste that has a radiation dose rate at the package surface of $\leq 200 \mathrm{mrem} / \mathrm{h}$. CH SLLW consists of various contaminated items such as laboratory 
equipment, facility refurbishment waste, D\&D waste, personnel protective clothing, air filters, and bulk materials such as soil, sludge, and construction debris.

The physical form of the waste is the primary factor controlling the selection of treatment methods. ORNL segregates CH LLW into two principal categories based on its physical characteristics: compactible and noncompactible.

Compactible waste. Compactible waste consists of dry materials such as plastic bags, paper, personnel protective clothing, light gage metal, and glassware that can be compacted by conventional compaction equipment. Compactible waste is segregated from other LLW streams, double-bagged in 4-mil plastic bags, and stored in steel, double-door, yellow dumpsters at the generator's facility. Compactible waste is treated at the ORNL compaction facility. In the future, waste may be incinerated or supercompacted at an off-site commercial treatment facility. The maximum unshielded surface dose rate of a bag of compactible waste is limited to $\leq 200 \mathrm{mrem} / \mathrm{h}$. Most compactible waste packages have a surface dose rate of $<10 \mathrm{mrem} / \mathrm{h}$.

Noncompactible waste. Noncompactible waste consists of large, heavy, or bulky items such as piping, equipment, instrumentation, heavy glass containers, wood, soil, concrete, and other debris that cannot be compacted at the ORNL compaction facility. Noncompactible waste is segregated from other waste streams, packaged in a 4-mil plastic bag, and placed in a 208-L (55-gal) metal drum or $1.2 \times 1.2 \times 1.8 \mathrm{~m}(4 \times 4 \times 6 \mathrm{ft})$ metal box. Bulk waste such as soil, gravel, concrete, asphalt, and other construction and demolition debris is generally packaged in plastic-lined $1.2 \times 1.2 \times 1.8 \mathrm{~m}(4 \times 4 \times 6 \mathrm{ft})$ metal boxes. Large items of noncompactible waste that will not fit in a drum or box, such as large tanks or vessels, are accepted on a case-by-case basis. Some noncompactible waste is transported to an off-site commercial treatment facility for incineration or supercompaction. The maximum surface dose rate of the outer container is limited to $\leq 200 \mathrm{mrem} / \mathrm{h}$. Most noncompactible waste packages have a surface dose rate $<10 \mathrm{mrem} / \mathrm{h}$.

\section{Remote-handled low-level waste}

RH LLW has a surface dose rate of $>200 \mathrm{mrem} / \mathrm{h}$ and consists of debris from reactors and hot cell operations, ion exchange resins, radioactive sealed sources, and solidified supernatants from MVSTs. RH LLW is subdivided into two categories for handling and long-term management: high-range and very high range. High-range waste is RH LLWW with a maximum contact reading $\leq 1 \mathrm{rem} / \mathrm{h}$. Very high range waste is RH LLW with a contact intensity $>1 \mathrm{rem} / \mathrm{h}$.

High-range waste. High-range waste $<1 \mathrm{rem} / \mathrm{h}$ consists of the same types of compactible and noncompactible materials as those described for CH LLW. High-range waste is generally double-bagged in 4-mil plastic bags and placed inside an outer container. Large items that will not fit in a plastic bag may be double-wrapped in plastic or placed in alternate containers. Approved outer containers are either 20-mil plastic bags, 3.8- to 75.7-L (1- to 20-gal) metal cans, or 114- or 208-L (30- or 55-gal) metal drums. High-range wastes are not treated because of the high dose rates.

Very high range waste. This waste consists primarily of obsolete equipment and materials contaminated with activation or fission products from reactors and from isotope production hot cells. Very high range wastes are packaged in an inner container, sealed, and placed in an outer container. The outer container is typically a 3.8- to 75.7-L (1- to 20-gal) 
metal can or a 114- or 208-L (30- or 55-gal) metal drum. This type of waste can have surface dose rates up to thousands of rem per hour and is handled as a special case (SC) waste. Because of its very high radiation level, this waste must be transported in shielded waste carriers or shielded transport casks. Very high range wastes are not treated because of the high dose rates.

Very high range wet solid wastes are also generated during treatment of LLLW. Dewatered ion exchange resins from reactor facilities and solidified supernatants from the MVSTs produce an RH LLW $>1 \mathrm{rem} / \mathrm{h}$. These waste streams are packaged in large steel or high-density polyethylene containers.

\section{Fissile waste}

Waste that contains ${ }^{233} \mathrm{U},{ }^{235} \mathrm{U},{ }^{238} \mathrm{Pu},{ }^{239} \mathrm{Pu},{ }^{241} \mathrm{Pu}$, and/or the isotopes of neptunium, americium, curium, berkelium, and californium are managed as fissile waste provided the concentration of the transuranic radionuclides with half lives $>20$ years is $<100 \mathrm{nCi} / \mathrm{g}$. For criticality and security reasons waste containing $\geq 1 \mathrm{~g}$ or $\geq 1 \mathrm{~g} / \mathrm{ft}^{3}$ of ${ }^{235} \mathrm{U}$ or its fissile mass equivalent is handled separately. All fissile wastes are packaged in containers that provide at least two containment barriers to prevent the inadvertent release of radioactive material during handling. The dose rate of fissile waste packages may be $>1 \mathrm{rem} / \mathrm{h}$. Fissile wastes are not treated because of the high dose rates.

\section{Biological waste}

Biological LLW consists of animal carcasses, tissues, excrements, and bedding that are generated when radionuclides are used in biological research. Also included are contaminated plants and animals from the ORR including deer, ducks, geese, trees, grass, and plants. Sewage sludge from the Sanitary Wastewater Treatment Facility is also managed as a biological LLW.

Radioactive animal carcasses and tissues are frozen and stored by the waste generator. Contaminated vegetation and sewage sludge is temporarily stored at an ORNL waste storage facility. When sufficient quantities of contaminated biological waste has accumulated, it is transported to an off-site commercial treatment facility for incineration. The treated waste is packaged in metal boxes and returned to ORNL for storage or disposal. The dose rate of biological LLW packages is usually much less than $10 \mathrm{mrem} / \mathrm{h}$.

\section{Asbestos waste}

Until the late 1970s, asbestos was used extensively at ORNL for the insulation of pipes. Asbestos waste is also found in floor tiles, ovens, and furnaces. Asbestos waste is generated during maintenance or demolition of contaminated facilities. Generally, asbestos waste is packaged in special, asbestos-labeled, 6-mil polyethylene bags, sealed with tape, and placed in a second asbestos-labeled polyethylene bag. Heavy materials such as asbestos tiles or bench tops are placed in fiberboard drums. Asbestos waste is not treated because of the asbestos dust hazard. The maximum dose rate of packaged asbestos waste is limited to $\leq 1 \mathrm{rem} / \mathrm{h}$. The typical dose rate of packaged asbestos waste is much less than $10 \mathrm{mrem} / \mathrm{h}$.

\section{Very low activity waste}

Very low activity (VLA) waste consist of debris that is generated during the D\&D or construction of facilities and other waste such as soil, air filters, wood, empty drums, laboratory equipment, and personnel protective clothing. VLA waste is waste that has no 
measurable external contamination but cannot be certified by routine Health Physics surveys as free of internal contamination. This waste type was formerly called suspect waste.

VLA waste is segregated from other LLW and placed inside a $1.2 \times 1.2 \times 1.8 \mathrm{~m}$ $(4 \times 4 \times 6 \mathrm{ft})$ metal box. Large items that will not fit in a metal box are stored in a sea-land container. The packaged waste is stored at an ORNL storage facility until transported off-site for incineration or supercompaction at a commercial treatment facility. The treated waste is packaged in metal boxes and returned to ORNL for storage or disposal. There are no external radiation readings on packages of VLA waste.

\section{Special case waste}

SC SLLW is waste that does not meet the criteria of the other SLLW types. Five categories of SC SLLW have been identified for management: (1) Performance Assessment limiting (PAL), (2) greater than NRC Class C (GTCC), (3) uncertified or uncharacterized, (4) high-level incidental waste, and (5) DOE loan/lease material.

SC PAL. Most SC PAL waste at ORNL would fall into the Low-Level Waste Disposal Development and Demonstration Program (LLWDDD) Classes L-III and L-IV. The Class L-III designation is primarily for those isotopes having long half-lives or those isotopes with intermediate half-lives that are environmentally mobile. The isotopes of uranium account for most of the volume of waste falling within the Class L-III limits. Other isotopes comprising the Class $\mathrm{L}-\mathrm{III}$ designation include those of $\mathrm{Th}, \mathrm{Np}, \mathrm{Am}, \mathrm{Be}, \mathrm{C}, \mathrm{Zr}, \mathrm{Pu}$, and Tc. ORNL currently generates $<3.25 \mathrm{~m}^{3} /$ year $\left(<115 \mathrm{ft}^{3}\right)$ of Class L-III waste.

The Class L-IV waste designation applies to isntopes having both short and long half-lives. Isotopic concentrations in waste exceedir on the isotope, the Class L-III limits) will prohibit Currently, ORNL generates $\sim 48.3 \mathrm{~m}^{3} /$ year $(\sim 1705 \mathrm{fl}$ the Class L-II limits (depending al of that waste on the ORR. ass L-IV waste.

SC GTCC. ORNL SC GTCC waste, a subset of Class L-IV waste, largely consists of small quantities of highly radioactive waste such as sealed radiation sources and activated parts from reactors. SC GTCC waste containing high-curie loadings requires special packaging, transport, and handling capabilities as well as unique storage facilities. The characteristics and quantities of ORNL waste in the SC GTCC category have not been determined. Sealed sources are also a subcategory of SC loan/lease material.

SC uncertified or uncharacterized (UC). Most of this waste at ORNL will fall into the Class L-III/IV PAL category. The characteristics and quantities of ORNL waste in the SC UC category have not been determined.

SC high-level incidental waste (HLI). ORNL has a small quantity of SC HLI waste in SWSA 5 storage wells that will fall into this category. This waste mainly consists of reactor fuel samples from reactors and irradiation tests, is highly radioactive, and must ' $\mathrm{e}$ handled and transported in shielded containers.

SC loan/lease material. SC loan/lease material consists of DOE-owned radioactive material commercially held by Nuclear Regulatory Commission (NRC) licensees. A large portion of this material is radioactive sealed sources held by universities. In $1991 \mathrm{DOE}$ Headquarters (HQ) requested interim storage of sealed so' 'ces at ORNL as part of DOE's program for managing NRC GTCC waste. ORNL has not stored any loan/lease material from NRC liscusees to date. 


\subsubsection{Treatment facilities}

ORNL has one treatment facility for dry solid CH SLLW. The ORNL waste compaction facility (Building 7831) is located in SWSA 5N. Building 7831 is a metal Butler-type building approximately $12 \times 13 \mathrm{~m}(40 \times 42 \mathrm{ft})$ divided into a personnel area and compactor area $6 \times 13 \mathrm{~m}(20 \times 42 \mathrm{ft})$ each. The box compactor is used to reduce the volume of compatible CH SLLW into $1.2 \times 1.2 \times 1.8 \mathrm{~m}(4 \times 4 \times 6 \mathrm{ft})$ metal boxes with a compressive force of $12 \times 10^{6} \mathrm{~Pa}(1750 \mathrm{psi})$. Off-site commercial treatment facilities are also used to reduce the volume of a portion of ORNL's CH SLLW. Commercial services are available for supercompaction, incineration, and metal melting.

ORNL has one liquid treatment process that produces a solid CH SLLW. Process wastewater is collected and treated at the PWTP. The PWTP removes radionuclides by clarification, filtration, and ion exchange. The ferrous hydroxide sludge from the clarifier is passed through a filter press to reduce the liquid content and packaged in drums for on-site storage or disposal. Commercial vendors are used to treat ion exchange resins and LLLW evaporator concentrates at ORNL. Additional treatment facilities are not currently planned for ORNL.

\subsubsection{Storage facilities}

In 1986 ORNL began interim storage of some CH SLLW at the Oak Ridge K-25 Site because of limited disposal capacity remaining in Solid Waste Storage Area (SWSA) 6. The K-25 Site uses surplus buildings for storage of $\mathrm{CH}$ SLLW with a surface dose rate $<50 \mathrm{mrem} / \mathrm{h}$. The intention was to store this waste until a new disposal facility was developed at another site on the ORR. Storage of CH SLLW at the K-25 Site was discontinued in 1991 because of limited existing storage space for RCRA waste. The K-25 Site is currently used to store only hazardous and mixed wastes generated on the ORR.

Because of the loss of the K-25 Site for storage of CH SLLW, ORNL has constructed several above-grade storage facilities; those currently used at ORNL include four portable Rubb structures in SWSA $5 \mathrm{~N}$. These facilities are used for interim storage of the low-activity waste streams such as contaminated soils, process wastewater sludge, biological waste, and VLA waste. ORNL plans to store these low-activity waste streams until new disposal facilities can be developed at other sites on the ORR or access is permitted at offsite DOE disposal facilities. New storage facilities for contaminated soil and other SLLW streams are also planned.

ORNL is also storing RH SLLW that does not meet the WAC for ORNL disposal facilities. RH LLW is stored in above-grade and below-grade storage facilities. Above-grade concrete cask storage areas in SWSA 6 and near the former ORNL Hydrofracture Facility are used to store solidified supernatants from the LLLW evaporator concentrate storage tanks. Below-grade storage wells in SWSAs $5 \mathrm{~N}$ and 6 are used to store spent fuel and fuel debris, irradiated hardware, sealed radiation sources, and other SLLW that does not meet the WAC for SWSA 6. The cask storage area near the NHF is also used to store irradiated hardware that is too large for the below-grade storage wells. These facilities have limited remaining storage capacity; thus, additional above-grade and below-grade storage facilities are planned at the ORNL SWSA 7 site. The plan is to store RH SLLW at ORNL until suitable disposal facilities are available at off-site DOE disposal facilities.

K-25 Site Storage Facility. Some CH SLLW is currently stored at the K-25 Site in Buildings K-310-2 and K-310-3, and Vault 31X. The K-25 Site Storage Facility, which can accommodate only CH SLL,W with a surface dose rate of $<50 \mathrm{mrem} / \mathrm{h}$, utilizes the surplus 
K-25 Site buildings for storage. The first waste stream shipped to the K-25 Site for interim storage was dewatered sludge from the PWTP (Building 3544) in 1986. This waste stream is fairly homogeneous and contains very low radioactivity. The PWTP waste and compactible waste in metal boxes were shipped to the K-25 Site for interim storage until 1991. A shortage of available permitted storage space forced the K-25 Site to stop accepting LLW from ORNL. New vault areas were prepared and placed in service in FY 1992 for hazardous and mixed wastes. Additional storage areas for SLLW may not be available at the K-25 Site. To date, approximately 2500 drums of SLLW and $1251.2 \times 1.2 \times 1.8 \mathrm{~m}(4 \times 4 \times 6 \mathrm{ft})$ boxes from ORNL are being stored at the K-25 Site.

Environmental monitoring. Monitoring of the facility is the responsibility of the K-25 Site.

Permitting status. Permitting of the storage facility is the responsibility of the K-25 Site.

Facility status. The facility is expected to be utilized in the future as additional permitted storage capacity is prepared and placed in service.

Buildings 7823B, 7823C, an : 823D. These buildings are fabric structures located on adjacent $9.8 \times 15.2 \mathrm{~m}(32 \times 50 \mathrm{tt})$ gravel pads near the south perimeter of SWSA 5 . Each pad is covered with a fabric structure with $3.4-\mathrm{m}(11-\mathrm{ft})$ walls and a $6.4-\mathrm{m}(21-\mathrm{ft})$ roof ridge. The fabric is fire resistant, PVC-coated polyester supported b' a hot-dipped, galvanized, angle iron framework anchored to the ground with steel spikes. Access to each structure is via a $4 \times 4 \mathrm{~m}(13 \times 13 \mathrm{ft})$ accordion-type door of the same fabric. No utilities are associated with the pads. Natural lighting is provided by translucent roof panels of the same fabric discussed above. These buildings are used only for storage of 208-L (55-gal) drums of SLLW or $1.2 \times 1.2 \times 1.8 \mathrm{~m}(4 \times 4 \times 6 \mathrm{ft})$ box-type SLLW containers that will eventually be placed in long-term storage or disposed of elsewhere. No SLLW processing activities will be conducted inside these buildings. The maximum capacity in Buildings $7823 \mathrm{~B}, 7823 \mathrm{C}$, and $7823 \mathrm{D}$ is 510 drums $\left[108 \mathrm{~m}^{3}\left(3825 \mathrm{ft}^{3}\right)\right]$, 528 drums $\left[112 \mathrm{~m}^{3}\left(3960 \mathrm{ft}^{3}\right)\right]$, and 480 drums $\left[102 \mathrm{~m}^{3}\left(3600 \mathrm{ft}^{3}\right)\right]$ respectively.

Environmental monitoring. These three buildings are monitored quarterly by Health Physics surveys and visual inspections by Waste Management Operations personnel.

Permitting status. A RCRA permit is not required for these facilities.

Facility status. Storage operations within these facilities began in 1991 and will continue for the foreseeable future.

Building 7823E. This facility is a tent-like fabric structure $12 \times 24 \mathrm{~m}(40 \times 80 \mathrm{ft})$ that has 3.4-m-high (11-ft) side walls and an overall roof peak of $6.4 \mathrm{~m}(21 \mathrm{ft})$. A $4 \times 4 \mathrm{~m}$ $(13 \times 13 \mathrm{ft})$ accordion-type door is available on one end. The building framework consists of hot-dipped galvanized steel that is attached to angle iron beams resting on a gravel pad surface. The building fabric cover (PVC-coated polyester) is flame resistant and is approved for use by the ORNL Fire Department. The facility has no utilities, but the roof fabric is translucent for internal light. This facility is used to store sealed 208-L (55-gal) drums or sealed metal boxes of solid low-level beta-gamma contaminated waste that is $\leq 200 \mathrm{mrem} / \mathrm{h}$ 
at the container surface. The maximum capacity is 1000 drums. Currently, $211208-\mathrm{L}$ (55-gal) drums $\left[45 \mathrm{~m}^{3}\left(1582 \mathrm{ft}^{3}\right)\right]$ are stored.

Environmental monitoring. Building $7823 \mathrm{E}$ is monitored quarterly by Health Physics surveys and visual inspections by Waste Management Operations personnel.

Permitting status. A RCRA permit is not required for this facility.

Facility status. Storage operations within this facility began in 1992 and will continue for the foreseeable future.

Building 7878A. This facility is a fabric tent structure $12 \times 30 \mathrm{~m}(40 \times 100 \mathrm{ft})$ located on a gravel pad in SWSA 6. This building is used as a staging and temporary storage area for CH LLW awaiting placement in concrete vaults that are subsequently placed on a tumulus pad in the IWMF. It will also provide interim storage for contaminated, recyclable lead stored in drums or boxes. The maximum capacity is $\sim 600$ boxes stacked three high.

Environmental ritonitoring. Building $7878 \mathrm{~A}$ is routinely monitored by Health Physics and visually inspected by Waste Operations personnel.

Permitting status. This facility is not permitted.

Facility status. Storage operations began in 1993 and will continue for the foreseeable future.

Emergency Avoidance Solidification Campaign (EASC) Site-Building 7856. An interim storage facility for storing solidified waste from the EASC of 1987 and the Liquid Waste Solidification Project (LWSP) is located near the NHF. This storage facility was designed specifically for storing the cement-solidified LLW generated during the processing of LLLW.

The solidified waste is contained in interim storage casks that were designed to provide (1) multiple containment barriers for the solidified waste form, (2) adequate shielding for the high-activity waste, and (3) sampling capabilities to monitor for the possible presence of entrained liquids and gases. The casks were fabricated of 0.3 -m-thick (1-ft) steel-reinforced concrete with an inner liner of corrosion-resistant synthetic, vinyl ester, fiber-reinforced plastic laminate. Each cask is $\sim 2.7 \mathrm{~m}(\sim 9 \mathrm{ft})$ in diam and $\sim 2.7 \mathrm{~m}$ $(\sim 9 \mathrm{ft})$ high and has a precast waterproof reinforced concrete cask lid $0.3 \mathrm{~m}(1 \mathrm{ft})$ thick. Sixty casks were used during the EASC campaign.

The storage facility consists of a graveled-pad interim-storage yard. The storage area is $\sim 91 \times 122 \mathrm{~m}(\sim 300 \times 400 \mathrm{ft})$. A layer of geotextile fabric was placed on top of a cleared and graded soil base. Six inches of crushed limestone was placed directly over the geotextile fabric and capped with an additional layer of compacted crushed limestone. The entire graveled area was sized to accommodate a maximum of about 160 casks. The storage area was enclosed with a chain-link security fence to control personnel entry.

The LWSP began in October 1991 and concluded in February 1992. Sixty-one casks were used during the LWSP campaign. 
Environmental monitoring. The facility is routinely monitored by the Operations Storage, Treatment, and Disposal Monitoring Program. The casks are monitored for releases of gases or entrained liquids on a routine basis.

Permitting status. A RCRA permit is not required for this facility.

Facility status. The Tennessee Department of Environment and Conservation (TDEC) will be notified of plans to ship waste to the Nevada Test Site pending approval of ORNL's application.

LWSP II Storage Facility. This facility is a graded, compacted gravel pad $\sim 46 \times 76 \mathrm{~m}(\sim 150 \times 250 \mathrm{ft})$ located within the SWSA 6 area of ORNL. The facility will be used to provide interim storage of LLLW that has been solidified in concrete inside large steel containers. The storage pad is designed to contain 120 storage casks and has room for additional expansion.

Environmental monitoring. The storage casks are designed so that the concrete storage cask inside can be monitored to determine any leakage from the steel waste container.

Permitting status. The solidified LLLW must meet SWSA 6 WAC.

Facility status. Sixty empty concrete storage casks are in place. The waste solidification campaign began during the first quarter of FY 1994.

Bulk Contaminated Soil Storage Facility. A building will be constructed in SWSA 7 to store radioactively contaminated soil generated during construction and maintenance activities at ORNL. This building will be used to store $\mathrm{CH}$ soil in metal containers.

The project shall consist of a pre-engineered, single-story metal building $\sim 15 \times 30 \mathrm{~m}$ $(\sim 50 \times 100 \mathrm{ft})$. It is to be erected on a reinforced concrete floor with curbing and a sump for spill containment and cleanup operations. The storage area will be able to contain 300 $1.2 \times 1.2 \times 1.8 \mathrm{~m}(4 \times 4 \times 6 \mathrm{ft})$ steel boxes stacked two high. The total storage capacity of this area is $\sim 8409 \mathrm{~m}^{3}\left(\sim 1100 \mathrm{yd}^{3}\right)$ of soil.

Environmental monitoring. ' $"$ nility will contain radiation alarm systems including alpha and beta/gamma air :uonitors and personnel monitors.

Permitting status. The facility will be permitted under RCRA.

Facility status. This project is a 1991 GPP with a TEC of $\$ 1.1 \mathrm{M}$. The Functional Requirements Document was issued in February 1991, and the Preliminary Proposal was approved and sent to DOE in August 1991. The project is on hold pending NEPA determination.

SLLW Staging Facility. A building will be constructed in SWSA 7 for staging and storing SLLW and mixed waste. The facility will be a pre-engineered metal building with curbs, sumps, fire protection, lighting, telephone service, and a paved access road. 
Environmental monitoring. The facility will be equipped to meet current and anticipated environmental monitoring requirements.

Permitting status. This facility is listed on the RCRA Part B permit application. An EA has been submitted to DOE-HQ to meet NEPA requirements.

Facility status. This project is a proposed 1994 GPP with a TEC of $\$ 760 \mathrm{~K}$.

Building 7827 shielded dry well. This facility is located in SWSA $5 \mathrm{~N}$ and provides retrievable storage of $\mathrm{SC}$ waste. Building 7827 , a two-section structure built in the ground, consist of 30 stainless steel-lined wells in one section and 24 stainless steel-lined wells in the other section. The bottom of each well cavity is sealed with a welded plug. Section 1

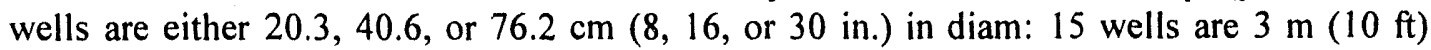
deep; the other 15 wells are $4.6 \mathrm{~m}(15 \mathrm{ft})$ deep. Section 2 wells are all $20.3 \mathrm{~cm}(8 \mathrm{in}$.) in diameter and $4.6 \mathrm{~m}(15 \mathrm{ft})$ deep. A 0.91 -m-thick (3-ft) stepped concrete plug is provided as a cover for each well. The waste is contained within sealed metal capsules inside a well cavity. The waste stored in this facility includes $2 \mathrm{~m}^{3}\left(75 \mathrm{ft}^{3}\right)$ of ${ }^{60} \mathrm{Co},{ }^{90} \mathrm{Sr}$, and ${ }^{226} \mathrm{Ra}$ sealed sources $(188,357 \mathrm{Ci}) ; 1.8 \mathrm{~m}^{3}\left(62 \mathrm{ft}^{3}\right)$ of spent fuel $(22,417 \mathrm{Ci})$; and $2.7 \mathrm{~m}^{3}\left(97 \mathrm{ft}^{3}\right)$ of other irradiated materials $(134,070 \mathrm{Ci})$. Environmental monitoring consists of routine radiation monitoring of the area. The waste is isolated from the groundwater by the closed-bottom well and its waste container.

One $20.3-\mathrm{cm}(8-\mathrm{in}$.$) well and one 76.2-\mathrm{cm}(30$-in.) well remain in this facility. The latter well has been designated for storage of SC HLI waste from the ORNL High Flux Isotope Reactor (HFIR). The current volume is $1.1 \mathrm{~m}^{3}\left(40 \mathrm{ft}^{3}\right)$ containing $13 \mathrm{Ci}$. This waste will remain in long-term storage until DOE develops a policy for managing $\mathrm{SC}$ wastes.

Environmental monitoring. Environmental monitoring consists of routine radiation monitoring of the area. The waste is isolated from the environment by the well and the stainless steel waste containers.

Permitting status. A RCRA permit is not required.

Facility status. This facility will continue to be used for long-term storage of the waste until DOE develops a policy for long-term management of SC waste.

Building 7829 shielded dry well. This facility is located adjacent to Building 7827 and provides retrievable storage of SC waste. Currently, only spent nuclear fuel materials from the Peach Bottom Nuclear Reactor are stored in this facility. Building 7829 is similar in design to Building 7827 except (1) it consists of only one section containing 10 wells and (2) all 10 wells are $30.5 \mathrm{~cm}$ (12 in.) in diam by $4.6 \mathrm{~m}$ (15 ft) deep. One empty well resiains in this facility.

Environmental monitoring. Environmental monitoring consists of routine radiation monitoring of the area. The waste is isolated from the environment by the well and the stainless steel waste containers

Permitting status. A RCRA permit is not required. 
Facility status. This facility was constructed in the early 1970s. The ten wells are full and will continue to be used for long-term storage of the waste until DOE develops a policy for long-term management of SC waste.

$7823 \mathrm{~A}$ storage wells. Eight stainless steel storage wells are in SWSA $5 \mathrm{~N}$. These wells are $\sim 6 \mathrm{~m}(\sim 20 \mathrm{ft})$ deep, have varying diameters, and are fitted with removable concrete plugs. The majority of the waste containers in these wells contain nuclear fuel material generated at the High-Radiation-Level Examination Laboratory (Building 3525) from 1972 to 1975 . The total volume is $1.2 \mathrm{~m}^{3}\left(43 \mathrm{ft}^{3}\right)$ containing $455 \mathrm{Ci}$. Much of this material is packaged in 15.2 -cm-diam (6-in.) stainless steel tubes. This waste is considered SC HLI waste.

Environmental monitoring. Environmental monitoring consists of routine radiation monitoring of the area. The waste is isolated from the environment by the well and the stainless steel waste containers.

Permitting status. A RCRA permit is not required.

Facility status. This facility will continue to be used for long-term storage of the waste until DOE develops a policy for long-term management of SC waste.

SWSA 6 RH LLW Retrievable Storage Area. Several below-ground retrievable storage wells have been constructed in SWSA 6. The wells are $4.6 \mathrm{~m}(15 \mathrm{ft})$ in depth and are fabricated from both 50.8- and 76.2-cm-diam (20- and 30-in.) carbon steel pipe. Each well has a welded bottom for leak tightness. The wells are constructed so that the waste can be retrieved for future treatment or disposal. Each 76.2-cm-diam (30-in.) well is fitted with three each $33-\mathrm{cm}(13-\mathrm{in}$.) inner pipes by $4.6 \mathrm{~m}$ (15 ft) long and one small PVC pipe for monitoring.

Environmental monitoring. The wells are designed with a inner PVC monitoring pipe to test for leakage of the well.

Permitting status. Material to be stored within the wells must meet SWSA 6 WAC.

Facility status. After disposal ceased in December 1992, the unused wells were identified in future plans for retrievable storage. No waste has been stored as of the end of November 1993.

\section{Class L-III and L-IV Below-Ground Storage Facility}

Planned for interim storage of Class L-III/IV RH waste, this new facility will consist of several below-grade, concrete vaults having multiple 4.6-m-deep (15-ft) storage wells in each vault. Each storage well will have a removable carbon-steel, double-wall liner.

Shielding will be designed to reduce the dose rate at exposed surfaces to $<2.5 \mathrm{mrem} / \mathrm{h}$. Each storage unit will be constructed so that the waste can be retrieved for future treatment or disposal. The facility will be designed so that additional vaults can be constructed as needed.

Environmental monitoring. Each liner will be designed so that the annular space in the double-wall liner can be monitored to detect leakage of the insert. 
Permitting status. The facility will be permitted under RCRA to store mixed waste. An EA was submitted to DOE-ORO in December 1991. A revised EA was submitted to DOE-ORO in March 1993. A second revision was submitted in August 1993. DOE-ORO anticipates that the EA will be submitted to DOE-HQ in October 1993.

Facility status. The Class L-III and L-IV Retrievable Storage Facility is a 1991 GPP having a TEC of $\$ 1.1 \mathrm{M}$. The facility will be located in SWSA 7 and will initially consist of one storage unit (eight wells). The Design Criteria was approved in June 1991. Additional storage units will be added as necessary. An expansion to the facility, planned as a 1995 GPP, will add an additional five wells.

The first GPP is currently in Title I and Title II Design and is projected to be completed in October 1993. The project cannot be bid until the EA is approved-probably in late 1994. Following approval of the EA, the bid, award, and construction phases will take approximately 2 years. If the project meets the anticipated schedule, the facility would be operational in late 1996.

\section{Class L-III and L-IV Aboveground Storage Facility}

A new waste storage facility is planned for storing Class L-III and L-IV CH waste. Conceptually, this facility will consist of several graveled benches cut in a hillside on the southern slopes of SWSA 7. Each bench will accommodate 96 casks or 30 above-grade concrete vaults. Each concrete storage module will provide sufficient shielding to reduce the dose rate at exposed surfaces to $<10 \mathrm{mrem} / \mathrm{h}$. Each module will be constructed for long-term storage and future retrievability of the waste.

Environmental monitoring. Each concrete module will contain an internal cavity for collecting and analyzing any liquids that might be resent in the module.

Permitting status. The facility will not be RCRA permitted. An EA that includes the Class L-III and L-IV Below-ground Storage Facility has been submitted to DOE for approval.

Facility status. The Class L-III and L-IV Aboveground Facility is a 1992 GPP having a TEC of $\$ 500 \mathrm{~K}$. The Functional Requirements Document was approved in October 1990. The preliminary proposal was issued, approved, and sent to DOE-ORO in August 1991. The GPP is in Title I and Title II Design and is projected to be completed in November 1993. The project cannot be bid until the EA is approved-probably in late 1994. Following approval of the EA, the bid, award, and construction phases will take approximately 2 years. If the project meets the anticipated schedule, the facility would be operational in late 1996.

\subsubsection{Disposal Facilities}

SWSA 6 is the only active LLW disposal area at ORNL. This site has been the only disposal area for ORNL LLW since 1973 when SWSA 5 closed. Until 1986 all SLLW generated at ORNL, including low-level mixed waste, was disposed by shallow land burial generally in unlined trenches and auger holes. In 1984 the practice of shallow land disposal on the ORR came under closer scrutiny by federal and state regulators and DOE officials. As a result, major changes in the operation of SWSA 6 were initiated in 1986 including (1) the exclusion of all mixed waste from disposal in SWSA 6, (2) the use of greater 
confinement disposal (GCD) techniques for below-grade disposal such as concrete silos and pipe-lined auger holes, and (3) the storage of some low-activity LLW at the K-25 Site and all mixed waste at ORNL. In addition to the GCD techniques for below-grade disposal, ORNL also developed plans in 1986 for demonstrating the above-grade tumulus disposal technology developed by the French.

Because of the disposal practices prior to 1986, some areas in SWSA 6 were partially remediated under a RCRA interim status closu. ; agreement with the TDEC. The remediation activities were coordinated with ongoing GCD waste operations. SWSA 6 will be remediated under the Comprehensive Environmental Response, Compensation, and Liability Act. The latest revision to the closure plan for SWSA 6 showed a Record of Decision being issued in September 1992 and closure beginning in December 1993. If the schedule had been met, all below-grade disposal in SWSA 6 was to end by December 1993 except above-grade tumulus disposal at the IWMF. The IWMF will be closed under a different schedule. Because of recent public concerns regarding the proposed remediation method for SWSA 6, a new date to begin site remediation has not been established. ORNL now plans to continue operation of the below-grade disposal units that meet the performance objectives of DOE Order 5820.2A until a new remediation schedule is developed. The SWSA 6 PA will determine which disposal units meet the performance objectives.

The disposal methods used for each type of waste disposed in SWSA 6 since the order was issued on September 26, 1988, is presented in Table 3.3. Details on the design,

Table 3.3. Disposal methods for waste disposed of in Solid Waste Storage Area $6^{a}$

\begin{tabular}{ll}
\hline \multicolumn{1}{c}{ Waste type } & \multicolumn{1}{c}{ Disposal unit } \\
\hline CH SLLW $(\leq 200 \mathrm{mrem} / \mathrm{h})$ & Low-range silos, tumulus \\
RH SLLW $(>200 \mathrm{mrem} / \mathrm{h}-\leq 1 \mathrm{rem} / \mathrm{h})$ & High-range silos \\
RH SLLW $(>1 \mathrm{rem} / \mathrm{h})$ & High-range wells in silos; high-range wells \\
Fissile waste & Fissile wells \\
Biological waste & Biological trenches \\
Asbestos waste & Asbestos silos \\
Very low activity & Suspect waste landfill \\
\hline
\end{tabular}

${ }^{a}$ This facility was considered for storage only after December 1992.

waste handling, and waste disposal operations for each disposal unit are discussed in the following subsections. The locations of SWSA 6 disposal units are shown in Fig. 3.10.

\section{Below-grade disposal}

Below-grade disposal methods that have been used In SWSA 6 include concrete silos, wells in concrete silos, pipe-lined auger hole wells, unlined trenches, and landfills. ORNL began phasing out some below-grade disposal operations in SWSA 6 in December 1992 at the request of the TDEC DOE Oversight Division because of concerns (1) about shallow land disposal in the trenches and landfill and (2) whether the below-grade wells would meet the long-term performance objectives of the order. Disposal in wells in concrete silos and piped-lined auger hole wells was suspended in December 1992 but may be converted to retrievable storage of very high range RH SLLW in FY 1994. The landfill was 


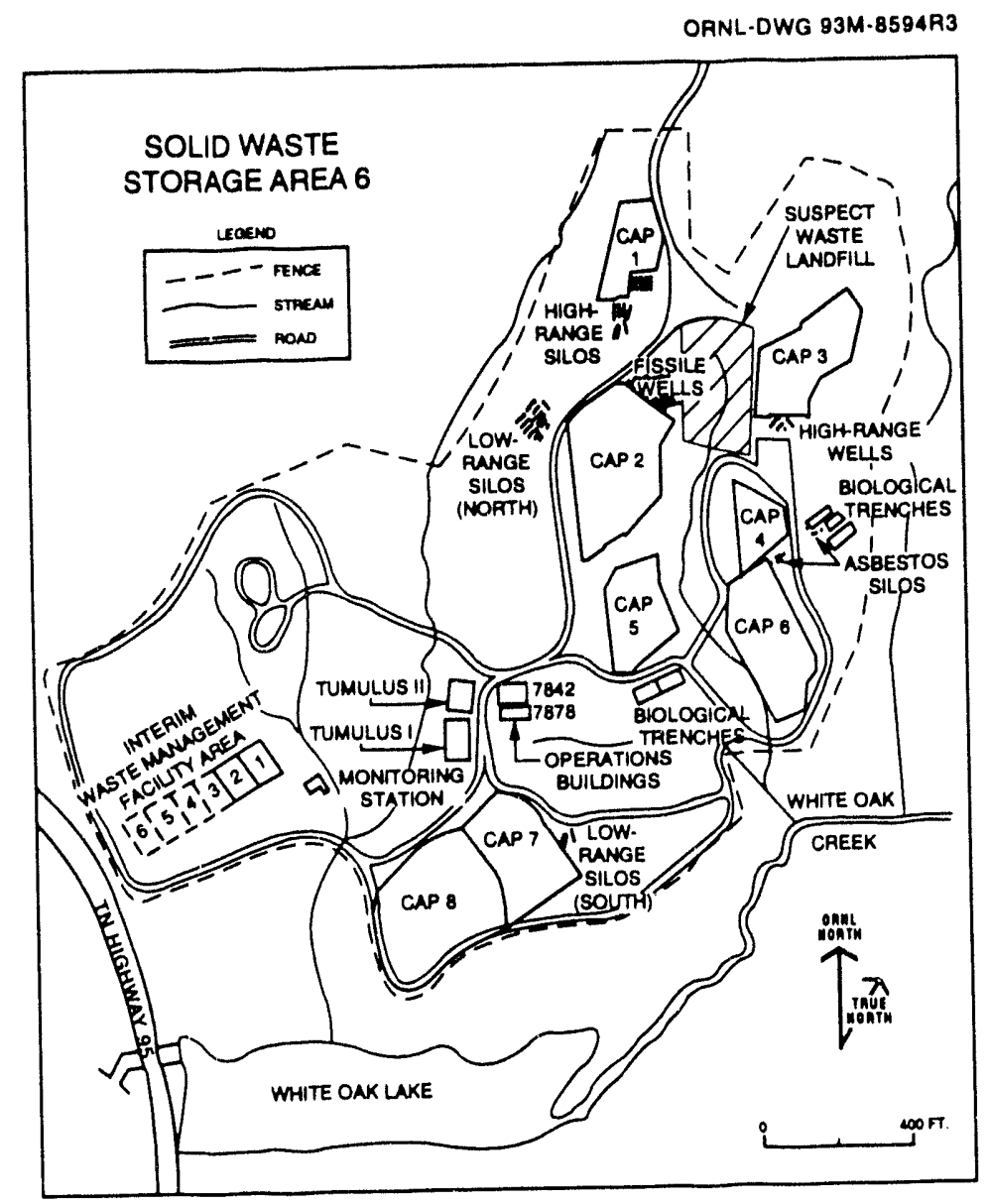

Fig. 3.10. Location of Solid Waste Storage Area 6 disposal units.

closed in December 1992 for disposal of VLA waste. The unlined trenches were phased out for animal wastes in December 1992 and for other biological wastes in March 1993. Only the concrete silos continue to be used for disposal of CH SLLW and high-range RH SLLW.

Low- and high-range silos. Concrete silos are used for disposal of low-range $(\mathrm{CH}$ SLLW) and high-range (RH SLLW $\leq 1 \mathrm{rem} / \mathrm{h}$ ) waste. These concrete silos are located in separate areas of SWSA 6 but are identical in construction. Silos are constructed of two 14-gauge, 4.9-m-long (16-ft), corrugated steel pipes: one $2.4 \mathrm{~m}(8 \mathrm{ft})$ in diam and the other $2.7 \mathrm{~m}(9 \mathrm{ft})$ in diam. A trench is dug $\sim 12.2 \mathrm{~m} \mathrm{(} \sim 40 \mathrm{ft})$ long by $\sim 4.6 \mathrm{~m}(\sim 15 \mathrm{ft})$ deep. The depth of the trench is always located and excavated with its lowest point a minimum of $0.6 \mathrm{~m}(2 \mathrm{ft}$ ) above the maximum water table elevation. Generally three or four silos are placed in the tre cil. The larger pipe is placed vertically in the trench with minimal space between the pipes and with the top of the pipe 15.2 to $30.5 \mathrm{~cm}$ ( 6 to $12 \mathrm{in}$.) above ground level. The smaller pipe is centered inside the larger pipe. The top of the inner pipe extends $\sim 15.2 \mathrm{~cm}(\sim 6 \mathrm{in}$.) above the top of the outer pipe.

A $6.1-\mathrm{m}(20-\mathrm{ft})$ section of 7.6-cm-diam (3-in.) PVC pipe with slots cut in the buttom 0.6 to $0.9 \mathrm{~m}(2$ to $3 \mathrm{ft})$ is used as a monitoring well in some of the silos. Another PVC pipe is placed outside the silos at the low point of the trench. The space around the silos is 
backfilled with dirt leaving the tops of the outer pipes $\sim 15.2 \mathrm{~cm}(\sim 6 \mathrm{in}$.) above finish grade. As the fill settles, more fill is added as required to provide water runoff away from the silo. A 0.3 -m-thick (1-ft), steel-rod-reinforced concrete pad is poured in the bottom of each silo. The annular space between the two pipes is filled with concrete. Each silo is painted with a unique number [e.g., TL-XXX (trench/low-range) or TH-XXX (trench/high-range)] on the outside of the $2.4-\mathrm{m}(8-\mathrm{ft})$ pipe that extends above the ground. A temporary cover is placed over the open silo when it is not being filled. A section view of a typical silo used for $\mathrm{CH}$ and RH SLLW is shown in Fig. 3.11.

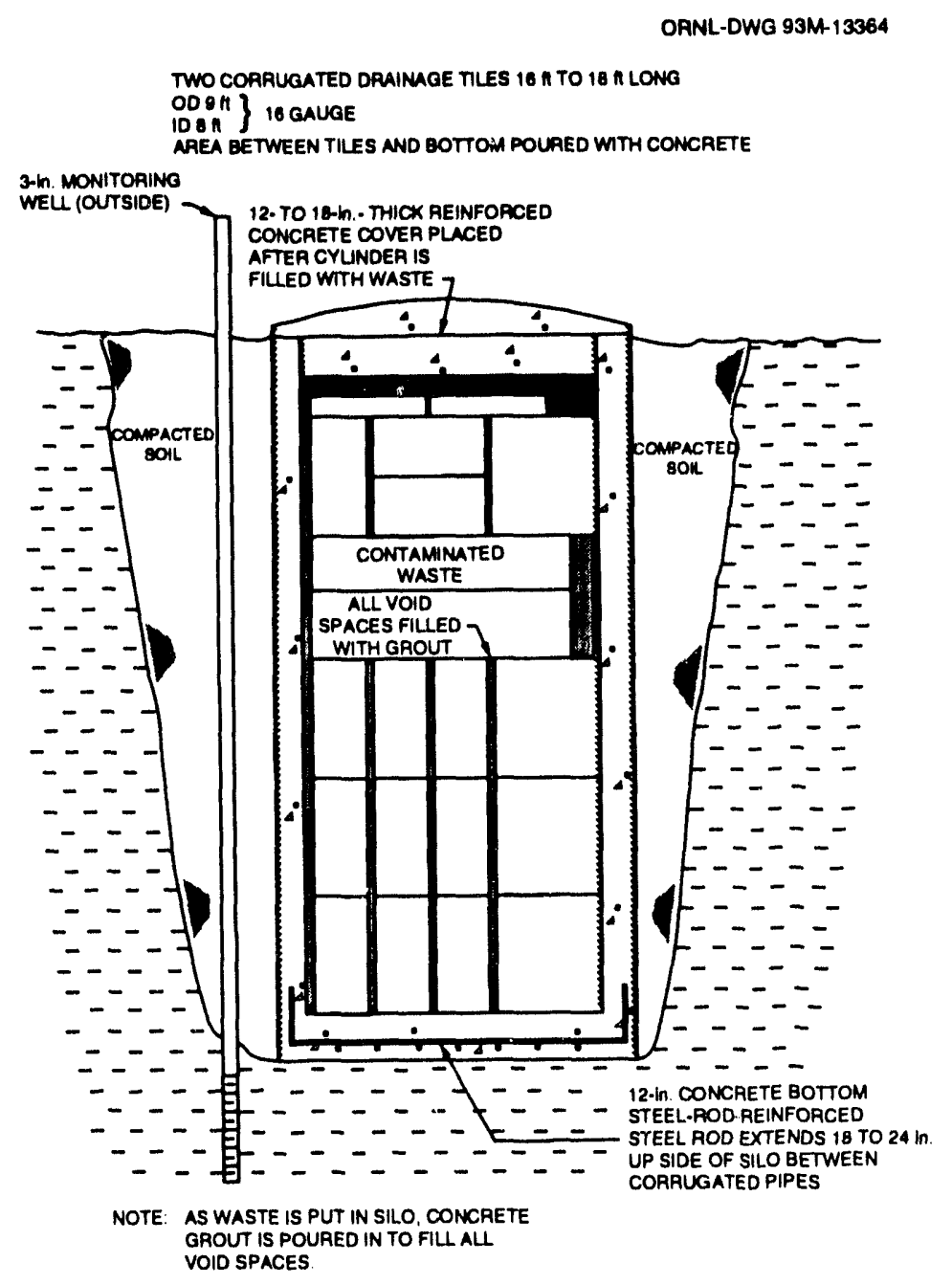

Fig. 3.11. Cross section of a concrete silo.

Generally, noncompactible bulky items, small boxes, 208-L (55-gal) drums, or soil are disposed of in the low-range concrete silos. Waste packaged in 20-mil plastic bags containing doubled-bagged waste or 3.8-, 7.6-, 19-, 37.9-, or 75.7-L (1-, 2-, 5-, 10-, or 20-gal) metals cans or 114- or 208-L (30- or 55-gal) metal drums are disposed of in the high-range silos. The packaged (drums only) $\mathrm{CH}$ SLLW is loaded on a transport vehicle and transported from the waste generator to WEAF for inspection by RTR. After successful inspection at WEAF, the waste is transported to a temporary storage facility or a staging area at the disposal site. RH SLLW is transported directly to the disposal site. A crane is used to remove the cover from the top of the silo and to lower the waste packages into the 
silo to prevent the packages from opening. Waste packages are placed as close to one another as practical to minimize the void space between containers. Waste is placed into the silo as long as the maximum radiation reading at the top of the silo does not exceed 200 $\mathrm{mrem} / \mathrm{h}$. After the silo is filled with waste, grout is poured between the waste packages to stabilize the waste. Waste placement and grouting is continued until the grout is within

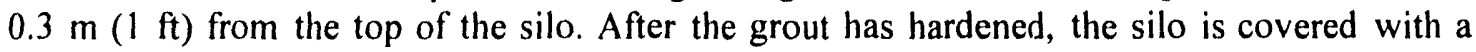
minimum 0.3-m-thick (1-ft), steel-rod-reinforced concrete cap. Prior to the concrete cap hardening, a stenciled bolt with the silo identification number is placed in the soft concrete cap.

The current management plan is to continue disposal of CH SLLW and RH SLLW that meets the WAC of the concrete silos until SWSA 6 is closed for below-grade disposal. Thereafter, the waste will be disposed of in the above-grade tumulus facility [i.e., the Interim Waste Management Facility (IWMF)] or stored on-site in above-grade concrete storage containers until new disposal facilities are constructed at other sites on the ORR or access to an off-site DOE disposal facility is available.

Asbestos silos. Contaminated asbestos waste is disposed of in dedicated concrete silos. The asbestos concrete silos are located in separate areas of SWSA 6 but are identical in construction to the concrete silos described previously in this subsection. Generally, asbestos waste is packaged in special, asbestos-labeled, 6-mil polyethylene bags, sealed with tape, and placed in a second asbestos-labeled polyethylene bag. Asbestos waste is transported from the generator's facility directly to the disposal site in dumpsters in a closed transport vehicle. Waste disposal and silo closure is in the same manner as that described for low- and high-range silos.

The current management plan is to continue disposal of asbestos waste that meets the WAC of the concrete silos until SWSA 6 is closed for below-grade disposal. Thereafter, the waste will be disposed in the above-grade tumulus (IWMF) or stored on-site in abovegrade concrete storage containers until new disposal facilities are constructed at other sites on the ORR or access to an off-site DOE disposal facility is available.

High-range wells in silos. A modified version of the previously described concrete silo was used for the disposal of very high range waste (RH SLLW $>1 \mathrm{rem} / \mathrm{h}$ ). A trench was dug $\sim 12.2 \mathrm{~m}(\sim 40 \mathrm{ft})$ long by $\sim 4.6 \mathrm{~m}(\sim 15 \mathrm{ft})$ deep. The depth of the trench was always located and excavated with its lowest point a minimum of $0.6 \mathrm{~m}(2 \mathrm{ft})$ above the maximum water table elevation. Three or four concrete silos constructed of one 16-gage, 4.9-m-long (16-ft), 2.7-m-diam (9-ft), corrugated steel pipes were placed in each trench with minimal space between the silos and with the top of the silo 15.2 to $30.5 \mathrm{~cm}$ (6 to $12 \mathrm{in}$.) above ground level. The space around the silos was backfilled with dirt leaving the top of the silo $\sim 15.2 \mathrm{~cm}(\sim 6 \mathrm{in}$.) above finish grade. As the fill settled, more fill was added as required to provide water runoff away from the silo. A $0.3-\mathrm{m}$-thick $(1-\mathrm{ft})$, steel-rod-reinforced concrete pad was poured in the bottom of each silo. A $6.1-\mathrm{m}(20-\mathrm{ft})$ section of 7.6 -cm-diam (3-in.) pipe with slots cut in the bottom 0.6 to $0.9 \mathrm{~m}$ ( 2 to $3 \mathrm{ft}$ ) was used as a monitoring well. The PVC pipe was placed inside each silo with the bottom resting on the concrete pad.

Seven wells were placed in a geometric array inside each silo. The wells were constructed of 2 -cm-thick $(0.75-\mathrm{in}$.) steel pipes, $5 \mathrm{~m}$ (16 ft) long with a $51-\mathrm{cm}(20-\mathrm{in}$.) ID. The annular space between the outside surface of the pipes and the inside surface of the silo was filled with concrete to $\sim 1.3 \mathrm{~cm}(\sim 0.5 \mathrm{in}$.) below the top of the pipes. A bolt stenciled with the well identification number was placed in the concrete at the top of each of the seven wells. Each well is identified by a unique number [e.g., WH-XXX (well/high-range)]. A temporary cover was placed over the open wells when they were not being filled. A 
typical section view of a concrete silo with high-range wells used for waste with a unshielded container dose rate $>1 \mathrm{rem} / \mathrm{h}$ is shown in Fig. 3.12.

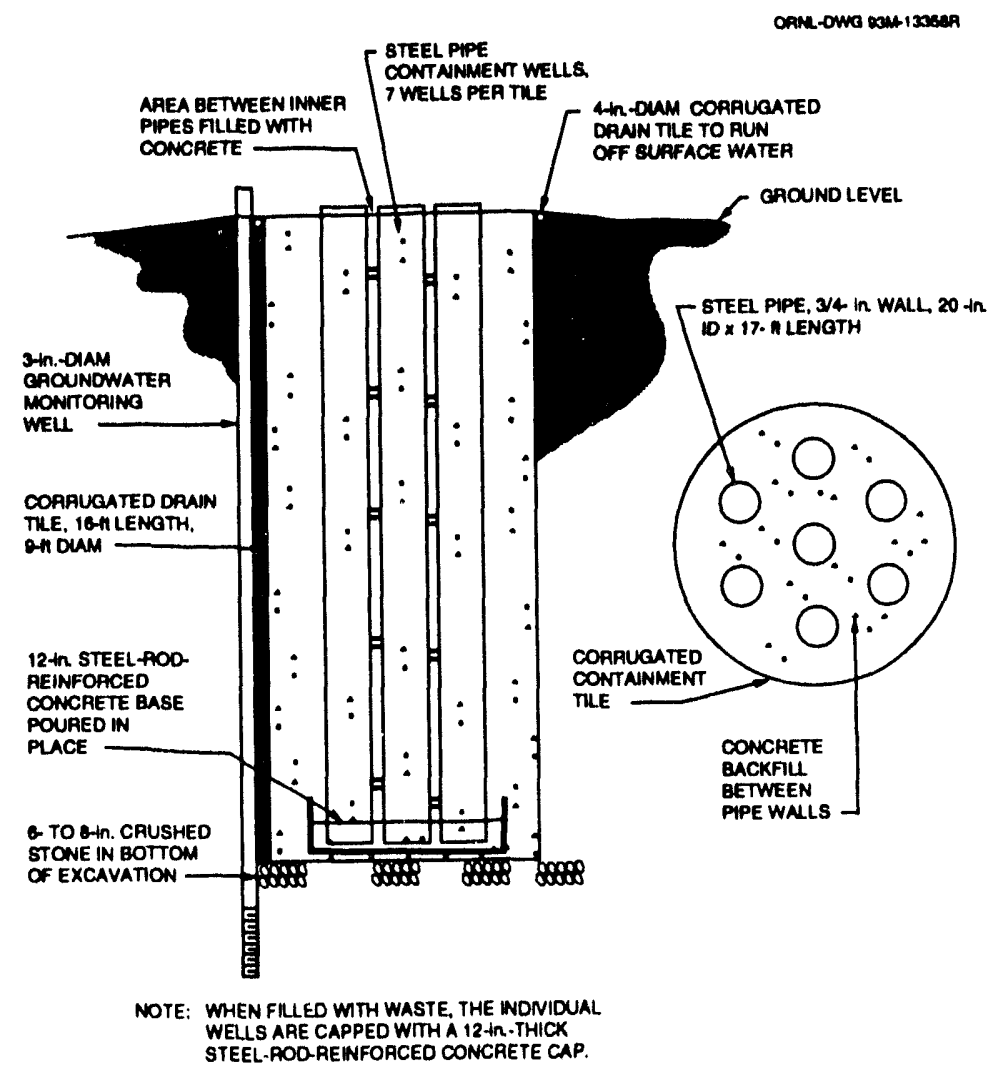

Fig. 3.12. Cross section of a concrete silo having high-range wells.

The waste disposed in concrete silos with high-range wells was packaged in 3.8-, 7.6-, 19-, 37.9-, or 75.7-L (1-, 2-, 5-, 10-, or 20-gal) metal cans or 114-L (30-gal) metal drums and transported to the disposal site in a lead-shielded, bottom-discharge carrier. Using a crane, the carrier was placed over the well, the bottom carrier drawer was opened, and the waste was lowered into the well. Prefabricated concrete plugs were placed in the well on top of the waste to reduce the radiation reading at the top of the well to $<200 \mathrm{mrem} / \mathrm{h}$. When a well in the silo was filled, the well was capped with a minimum $0.3-\mathrm{m}$ (1-ft) steel-rodreinforced concrete cap. Prior to the concrete cap hardening, a stenciled bolt with the well identification number was placed in the soft concrete cap. The radiation reading over the top of a closed well was $<2.5 \mathrm{mrem} / \mathrm{h}$.

Very high range wastes are no longer disposed in high-range wells in concrete silos. This waste is managed as SC waste and is transported to ORNL retrievable storage wells in shielded waste carriers. The current waste management plan for very high range LLW is to store the waste on-site until access to an off-site DOE disposal facility is available.

High-range wells. Heavy-wall steel pipe wells were also used to dispose of very high range waste $(\mathrm{RH}$ SLLW) $>1 \mathrm{rem} / \mathrm{h}$. These wells were constructed of 2 -cm-thick $(0.75$-in.) steel pipe vertically centered in a drilled auger hole, the top of which is approximately $15.2 \mathrm{~cm}$ (6 in.) above ground level. The surrounding space was backfilled with dirt. The pipes were generally $5-\mathrm{m}$ (16-ft) long with an ID of $76.2 \mathrm{~cm}(30 \mathrm{in}$.). A $0.3-\mathrm{m}$-thick $(1-\mathrm{ft})$ concrete plug was poured in the bottom of the well. 
A monitoring well, made from a 7.6-cm-diam (3-in.) polyvinylchloride pipe with a bottom cap and slotted $0.3 \mathrm{~m}(1 \mathrm{ft})$ from the bottom, was placed outside the well to allow collection of liquids for sampling and quarterly monitoring of the hydrological isolation of the well. The top of each well is painted with a unique identification number [e.g., WH-XXX (well/high-range)]. A typical section view of a high-range well used for $\mathrm{RH}$ SLLW with an unshielded container dose rate $<1 \mathrm{rem} / \mathrm{h}$ is shown in Fig. 3.13.

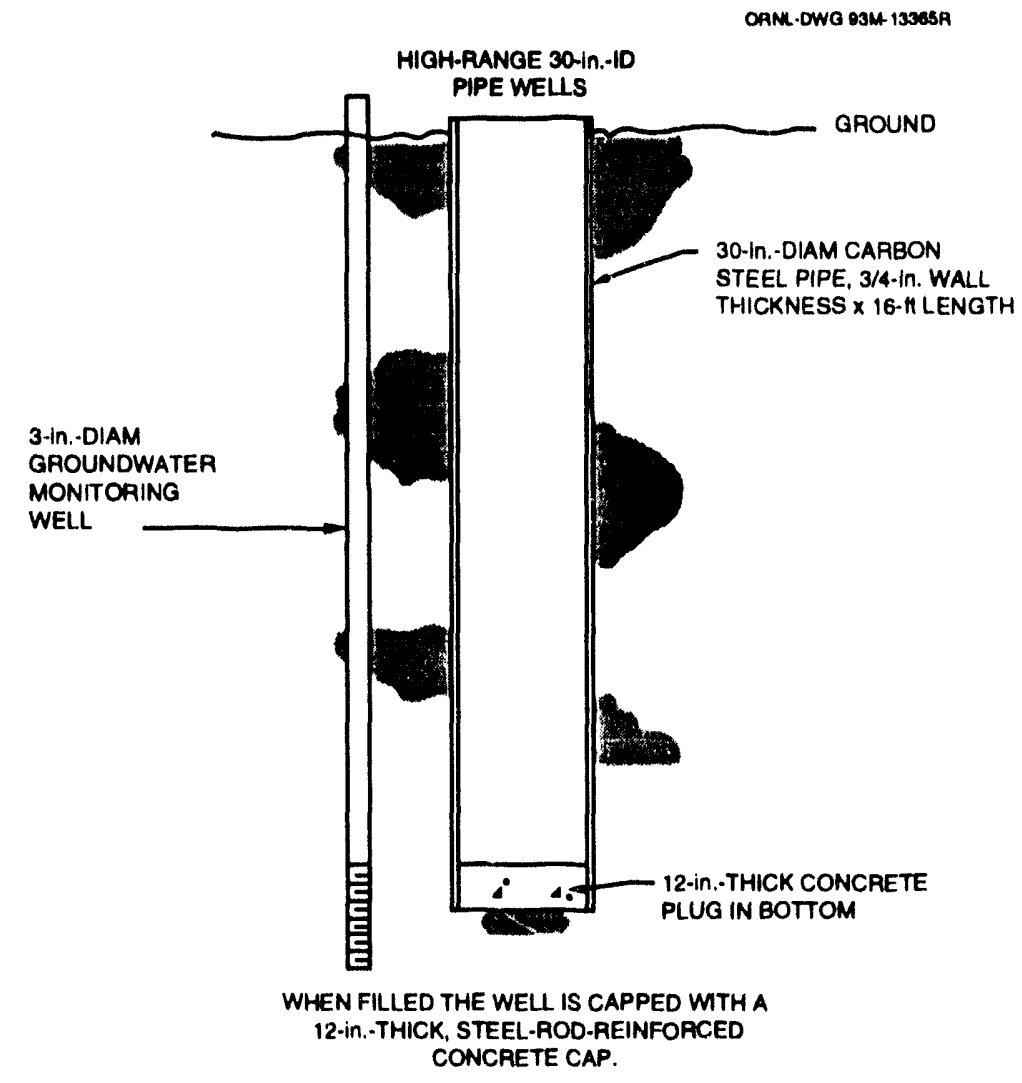

Fig. 3.13. Cross section of a high-range well.

Generally, only waste packaged in 208-L (55-gal) metal drums was disposed of in high-range wells. The waste was transported to the burial site and disposed of in the samie manner as the high-range wells in silos. After the well was filled, the well was capped with a minimum 0.3-m-thick (1-ft), steel-rod-reinforced concrete cap. Prior to the concrete cap hardening, a stenciled bolt with the well identification number was placed in the soft concrete cap. After closure and capping the well, the radiation reading over the top of the well was $<2.5 \mathrm{mrem} / \mathrm{h}$.

Very high range wastes are no lonzer disposed of in high-range wells. Routine disposal ceased in December 1992. This waste is managed as SC waste and is transported to ORNL retrievable storage wells in shielded waste carriers. The current waste management plan for very high range SLLW is to store the waste on-site until access to an off-site DOE disposal facility is available.

Fissile Wells. Fissile waste was disposed of in dedicated fissile wells. The fissile wells were constructed in the same manner as the high-range wells described previously. Fissile wells were spaced so that a minimum of $0.9 \mathrm{~m}(3 \mathrm{ft})$ of earth separates the sides of adjacent wells. Fissile wells are numbered WF-XXX (well/fissile). Fissile waste was packaged in 3.9- to 75.7-L (1- to 20-gal) cans or 114- to 209-L (30- to 55-gal) drums, 


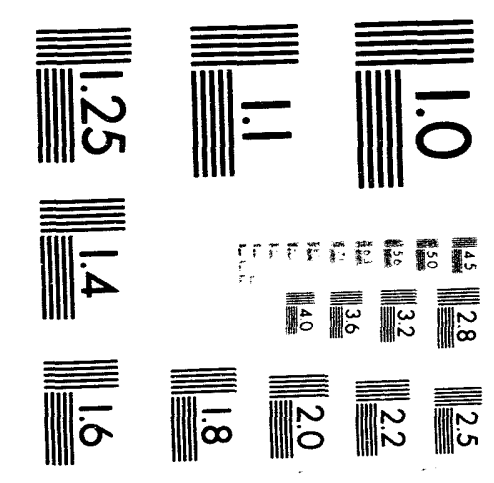



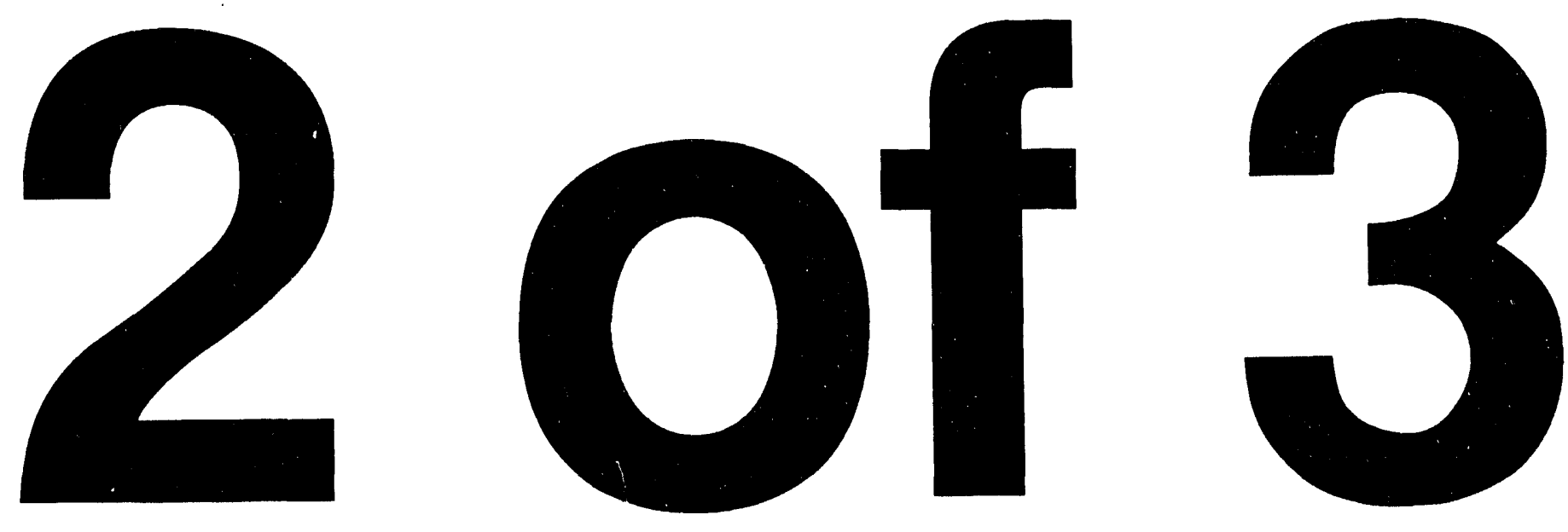
transported to the burial site in a shielded waste carrier, and disposed of in the same manner described for the high-range wells. The well was capped in the same manner described for the high-range wells.

Fissile waste is no longer disposed in fissile wells. Disposal ceased effective December 1992. This waste is also managed as SC waste and is transported to ORNL retrievable storage wells in shielded waste carriers. The current waste management plan for fissile waste is to store the waste on-site until access to an off-site DOE disposal facility is available.

Biological Trenches. Biological waste was disposed in trenches that were $\sim 3$ to $15 \mathrm{~m}(\sim 10$ to $50 \mathrm{ft})$ long and $3 \mathrm{~m}(10 \mathrm{ft})$ wide. The depth of the trenches varied depending upon the water table elevation. The lowest point in the trench was at least $0.6 \mathrm{~m}(2 \mathrm{ft})$ above the known maximum water table elevation, and spacing between adjacent trenches was at least $1.5 \mathrm{~m}(5 \mathrm{ft})$. The trench was graded to slope to one end at a rate of approximately 4 $\mathrm{cm} / \mathrm{m}(0.5 \mathrm{in} . / \mathrm{ft})$. Trenches were separately located from other waste disposal sites. Each trench is identified by a unique number [e.g., TB-XXX (trench/biological)]. Surface water drainage is controlled by separate ditching around the trench that conforms to existing topographic conditions. The ditching is compatible with the overall drainage network of the waste area regardless of whether the trench is on standby, in use, or closed.

The trenches were located and oriented for the most efficient and practical land usage. The trenches were sized and sectioned by removable steel plates to improve efficiency of land usage and to prevent trench sidewall collapse. In the event that unforeseen fluctuations in the water table might cause the excavation to fall below the water table, the trench was backfilled with Conasauga shale to a depth of at least $0.6(2 \mathrm{ft})$ above the maximum water table. After biological waste was placed in the trench, it was covered with at least $0.9 \mathrm{~m}(3 \mathrm{ft})$ of dirt. When the trench was filled, the surface of the closed trench was planted with grass, mowed, and kept free of trees.

Biological waste is no longer disposed of in the SWSA 6 biological trenches.

Biological waste was last disposed of in March 1993. The current waste management plan is to incinerate the waste at an off-site commercial treatment facility. The treated waste will be returned to ORNL for storage or disposal in the above-grade tumulus facility (i.e., IWMF).

Suspect Waste Landfill. VLA waste was disposed of in an open landfill northeast of SWSA 6. The landfill covered less than one acre. After disposal, the waste was covered with at least $0.30 \mathrm{~m}(1 \mathrm{ft})$ of soil. VLA waste is no longer disposed of in the landfill.

Operations were suspended on December 11, 1992.

VLA waste is segregated from clean material and other SLLW and is placed inside a $1.2 \times 1.2 \times 1.8 \mathrm{~m}(4 \times 4 \times 6 \mathrm{ft})$ metal box. Large items that will not fit in a metal box are stored inside a large cargo container (Sea/Land). The packaged VLA waste is stored at an ORNL storage facility until transported off-site for treatment by incineration or supercompaction. The treated waste is packaged in metal boxes and returned to ORNL for storage or disposal in the IWMF or low-range silos.

\section{Above-grade tumulus disposal}

Above-grade tumulus is the preferred method for disposal of CH SLLW on the ORR. Tumuli I and II were used for the disposal of CH SLLW from April 1988 through March 1992. The IWMF began operation in December 1991 and will provide disposal of CH SLLW until the proposed Class L-II disposal facility is constructed. This facility will be located in the West Bear Creek Valley. 
Performance assessments. DOE Order 5820.2A, Chap. III, requires that each operating LLW disposal facility meet radiological performance objectives:

- to protect public health and safety in accordance with standards specified in environmental health orders and other DOE orders;

- to ensure that external exposure to the wastes and concentrations of radioactive material that may be released into surface water, groundwater, soil, plants, and animals results in an effective dose equivalent that does not exceed $25 \mathrm{mrem} / \mathrm{year}$ to a member of the public (releases to the atmosphere should maintain releases of radioactivity in effluents to the general environment as low as reasonably achievable);

- to ensure that the committed effective dose equivalents received by individuals who inadvertently intrude into the facility after loss of active institutional control (i.e., 100 years) will not exceed $100 \mathrm{mrem} /$ year for continuous exposure or $500 \mathrm{mrem}$ for a single acute exposure; and

- to protect groundwater resources consistent with federal, state, and local requirements.

DOE Order 5820.2A requires a site-specific PA on all new disposal facilities and for any disposal facility that was in operation as of September 26, 1988. WMRAD has been assigned by the ESWMO the responsibility for preparation and issuance of the radiological PA for SWSA 6.

A preliminary PA was prepared for disposal technologies and active disposal units (as of September 26, 1988) in SWSA 6 and for the Class L-II IWMF located in the southwestern portion of SWSA 6. The draft report was submitted to DOE in September 1990 for review by the DOE Peer Review Panel. The preliminary PA indicated that many of the disposal units in SWSA 6 do not at present meet the performance objectives of DOE Order 5820.2A. Work is ongoing to evaluate the uncertainties and to improve the analysis in the PA. A final report will be issued that reflects the resolution of the comments received by the DOE Peer Review Panel. The final PA for SWSA 6 and IWMF is scheduled to be delivered to DOE-ORO for submittal to DOE-HQ in December 1993. The current strategy for managing ORNL LLW is to develop radionuclide concentration limits for the IWMF based on the final results of the PA.

Tumulus Disposal Demonstration Project. The TDDP was developed and implemented as part of the LLWDDD Program. ORNL was assigned the responsibility for the design and construction of the Class L-II tumulus disposal facilities. The purpose of this project was to demonstrate the ability of an above-grade disposal facility to contain the release of SLLW to the environment. Tumulus disposal involves packaging SLLW in steel boxes, placing the steel boxes inside concrete vaults (Fig. 3.14), stacking the vaults on a curbed concrete pad, and capping with natural materials.

The first tumulus pad (Tumulus I) was constructed in SWSA 6 during early 1987. Actual loading of concrete vaults onto the pad begin in April 1988. The Tumulus I pad was filled to capacity in June 1990, and a tent was installed over the entire facility after Tumulus II was filled to capacity. A total of 290 vaults [approximately $788 \mathrm{~m}^{3}\left(27,840 \mathrm{ft}^{3}\right)$ ] were placed on the Tumulus I pad.

Tumulus $I$ is located on an approximately 0.60 -ha $(1.5$-acre $)$ site in the south area of SWSA 6 . Tumulus 1 is $\sim 19.8 \times 32 \mathrm{~m}(-65 \times 105 \mathrm{ft})$. The pad was constructed using highstrength $(6000 \mathrm{psi})$ concrete and reinforced using epoxy-coated rebar. The concrete pad varies in thickness from $20.3 \mathrm{~cm}(8 \mathrm{in}$.) in the center to $40.6 \mathrm{~cm}$ (16 in.) along the perimeter of the pad. The pad has a concrete curb $15.2 \mathrm{~cm}(6 \mathrm{in}$.) high along the entire perimeter. The concrete pad was designed to serve as the primary leachate collection system for any 


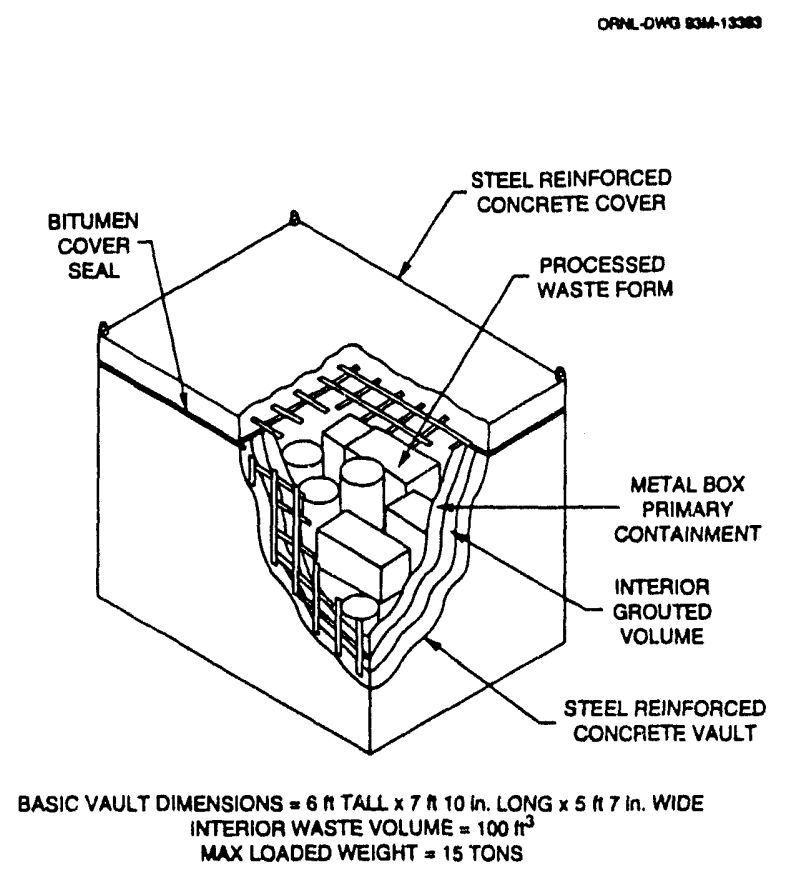

Fig. 3.14. Generic concrete cask for tumulus disposal operations.

leachate generated during operations and after closure. Surface drainage channels were constructed north, east, and south of the pad to divert surface runoff away from the pad.

The concrete vaults that were loaded and doubled-stacked on the concrete pad are designed to be used as structurally stable overpacks for containerized SLLW. The concrete vaults are $\sim 0.2 \mathrm{~m}(\sim 8 \mathrm{in}$.) thick and are $1.6 \mathrm{~m}(5 \mathrm{ft} 5 \mathrm{in}$.$) high, 1.7 \mathrm{~m}(5 \mathrm{ft} 7 \mathrm{in}$.)

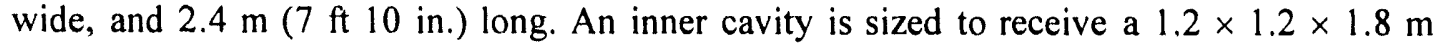
$(4 \times 4 \times 6 \mathrm{ft})$ metal box with a $10.2-\mathrm{cm}(4-\mathrm{in}$.) annular space. After the containerized solid LLW is placed in the vault, the annular space is filled with concrete, and a $0.2-\mathrm{m}$-thick (8-in.) precast concrete lid is placed on the vault and sealed with bitumen. The loaded and sealed concrete vaults are subsequently placed and stacked on the tumulus pad in rows abutting each other.

One of the principal features of tumulus disposal is the inherent capability for monitoring surface and groundwater for contamination. The sealed concrete pad is the primary barrier from the groundwater. The pad is sloped $1 \%$ to one side where a curb and gutter collect all surface pad runoff and drain the water to a monitoring station. A liner below the pad provides a secondary barrier from the groundwater and collects any water that may have penetrated the pad. Any water collected in the secondary barrier is also diverted to the monitoring station. The monitoring station is equipped for receiving, monitoring, and collecting samples from flows received from both the surface pad drain and under-pad liner drain systems.

Tumulus II disposal. The Tumulus II facility was operated after the Tumulus I pad was filled and preceded the operation of the IWMF. The Tumulus II pad began operation in October 1990 and was filled to capacity in March 1992. A tent was installed over the entire facility. A total of 220 vaults $\left[\sim 598 \mathrm{~m}^{3}\left(\sim 21,120 \mathrm{ft}^{3}\right)\right]$ were placed on the Tumulus II pad.

Tumulus II is located on an $\sim 0.40$-ha $(\sim 1$-acre $)$ site just north of the Tumulus I pad. The tumulus pad is $\sim 18.2 \times 27.4 \mathrm{~m}(\sim 60 \times 90 \mathrm{ft})$ and $30.5 \mathrm{~cm}(12 \mathrm{in}$.$) thick. The pad was$ 
constructed of high-density concrete and reinforced with epoxy-coated steel rebar. The pad has concrete curbs $0.30 \mathrm{~m}(1 \mathrm{ft})$ high on the south, east, and west sides. The north side does not have a curb and was used for vehicle access during vault-loading operations. The loading area was adjacent to the north side of the pad and was constructed of crushed stone. Surface drainage channels are constructed north and east of the pad. These channels are connected to the existing surface drainage channels for Tumulus $\mathrm{I}$.

\section{Interim Waste Management Facility}

The IWMF is the only active above-grade tumulus disposal facility in SWSA 6 . The IWMF occupies an area of $\sim 3.8$ ha $(\sim 9.5$ acres $)$ in the southwest portion of SWSA 6 . Each tumulus pad is $\sim 18.2 \times 27.4 \mathrm{~m}(\sim 60 \times 90 \mathrm{ft})$ and $30.5 \mathrm{~cm}(12 \mathrm{in}$.) thick. The pads are constructed using high-density concrete and reinforced with epoxy-coated steel rebar. The pad has concrete curbs $0.30 \mathrm{~m}(1 \mathrm{ft})$ high on the north, south, and west sides. The east side does not have a curb and is used for vehicle access during vault loading operations. Each pad provides disposal for approximately 330 vaults [approximately $897 \mathrm{~m}^{3}\left(31,680 \mathrm{ft}^{3}\right)$ ] stacked three high.

The IWMF has been designed to divert water into three sumps. The sumps are located in a monitoring system adjacent to the tumulus pads. The monitoring station is equipped for receiving, monitoring, and collecting samples from flows received from the stormwater, underpad, and infiltration drain systems. The underpad sump is designed to allow monitoring of any groundwater that may accumulate under the pads. The stormwater sump collects water from the pad that is in operation. The infiltration sump is used to collect water from the pads that have been filled with vaults. An illustration showing vaults stacked on the curbed concrete pad, drain lines, and the proposed tumulus cap is shown in Fig. 3.15.

\section{ESWMO Class L-I Disposal Facility}

The ESWMO has been assigned the responsibility for the development of new Class L-I and L-II SLLW disposal facilities on the ORR. Candidate sites for the new Class L-I disposal facility included the Far West Chestnut Ridge and West Chestnut Ridge; West Chestnut Ridge is the preferred site. Conceptually, the Class L-I will consist of a series of below-grade trenches with an average depth of $91 . \mathrm{m}(30 \mathrm{ft})$, length of $183 \mathrm{~m}(600 \mathrm{ft})$, and width of $61 \mathrm{~m}(200 \mathrm{ft})$. Trench dimensions will vary in an effort to optimize space available for disposal. The trenches will be lined on the sides and the bottom with a synthetic membrane. The bottom of the trench will have an additional clay liner under the synthetic liner, and both liners will have associated sumps and leachate collection systems. Each trench will be designed to handle $\sim 4.5 \times 10^{4} \mathrm{~m}^{3}\left(\sim 1.6 \times 10^{6} \mathrm{ft}^{3}\right)$ of Class L-I waste (assuming $50 \%$ trench disposal efficiency). Sedimentation basins will be constructed to catch and to hold uncontaminated water originating from the site and trenches during operations. Leachate collected from the liner systems will be transferred to a wastewater treatment facility at ORNL for processing and release to surface waters. Ancillary facilities will include an administration building, a waste verification station, a waste-staging area, a heavy equipment storage facility, a decontamination vehicle monitoring station, and a guard portal.

The ORR Class L-I disposal facility was anticipated to be operational by the end of 1996. The project schedule has slipped significantly because of delays in the preparation of NEPA documentation and lack of funding. In August 1991 ESWMO requested DOE-ORO to authorize funding for FY 1992 engineering support for the Class L-I and L-II disposal facilities to complete Conceptual Design Reports for both projects by March 31, 1992. This 


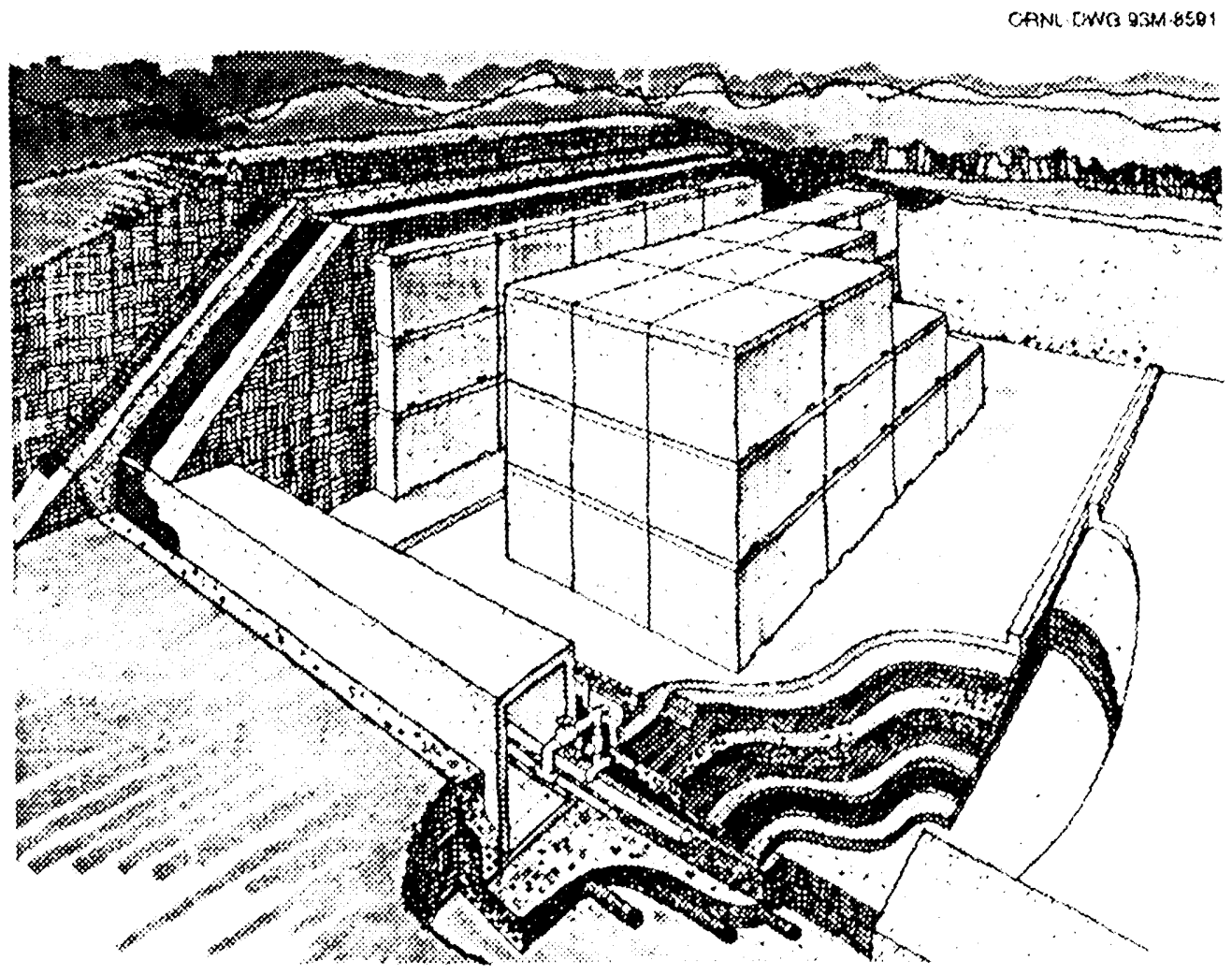

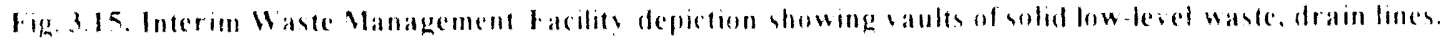
and final cover.

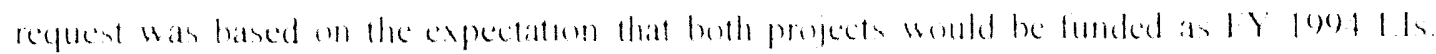

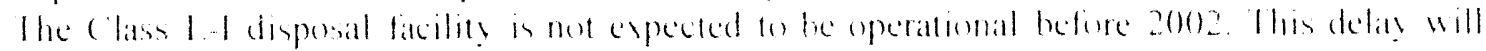

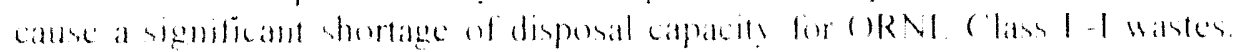

\section{ESWMO (Class 1 - 11 Disposal Facility}

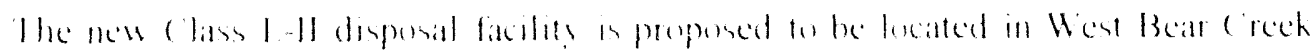

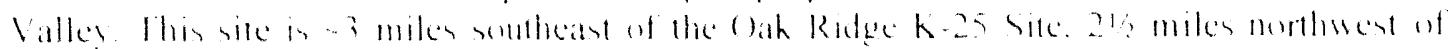

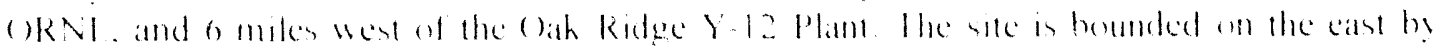

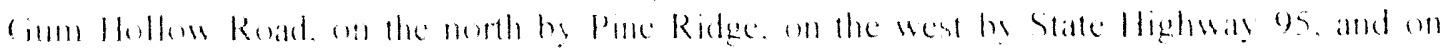

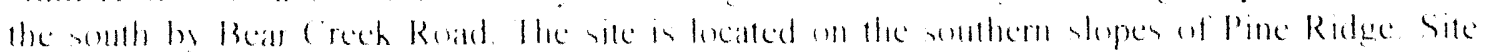

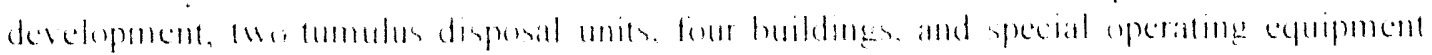
will be provided

The sile development will he directed at preparing an area that can suppont

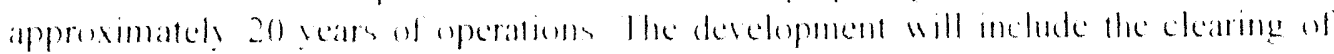

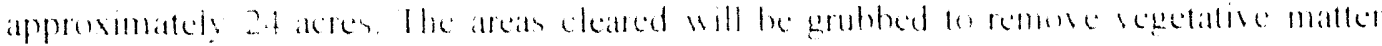

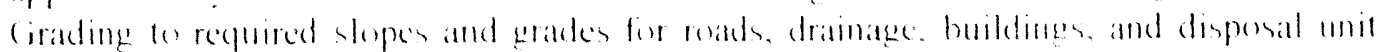

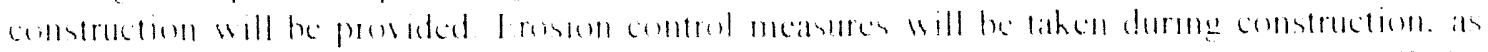

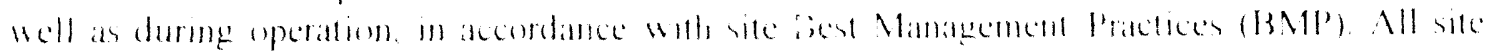
monef will be chanteled to a stormwater detemtion basin. 
The ESWMO Class L-II disposal facility was anticipated to be operational by the end of 1996. Delays in the preparation of NEPA documentation have deferred the LI project to FY 1994. In FY 1991 the preferred site for the facility was taken away by the Nuclear Weapons Reconfiguration Site (Complex 21) project planning. The first units of the Class L-II disposal facility are expected to be available in 1999.

\section{Database management}

SWIMS is the database for both SLLW and TRU solid radioactive waste. ORNL manages and administers this database and provides input to the national integrated database.

\subsubsection{Update of implementation summary table}

Appendix A provides an update to the original implementation summary for management of SLLW that was provided in the Oak Ridge National Laboratory

Implementation Plan for DOE Order 5820.2A. The format in Appendix A duplicates the format of the requirements for the management of SLLW contained in DOE Order 5820.2A. Many activities planned for achieving compliance with the order are applicable to more than one requirsment. To avoid duplication of costs for achieving compliance, cross-referencing between requirements is used extensively.

The most significant revision to the table results from the deletion of LLWDDD Program activities. As Subsect. 2.1.3.4 of last year's plan notes (WMRAD December 1992), tasks originally assigned to the LLWDDD Program (for achieving compliance with the DOE Order 5820.2A) have been reassigned to the appropriate Energy Systems installations. The change in total cost in this table, as a result of this shift in strategy, does not reflect a reduction in cost but rather a redistribution of costs between all Energy Systems installations. Other revisions to the table are minor and reflect points of edification and/or slight changes in strategic planning.

\subsubsection{General plant projects}

A listing of proposed LIs and GPPs for SLLW facilities and facility upgrades at ORNL is provided in Table 3.4. This table indicates the project title, TEC, and the respective fiscal year for funding.

\subsection{LIQUID WASTE}

ORNL employs two systems for handling and processing liquids that contain radioactive constituents: the LLLW System and the Process Waste System (PWS). The LLLW System handles waste solutions with a significant amount of radioactivity including waste streams originating from R\&D facilities and from other facilities such as nuclear reactors and the concentrate from the PWTP (Building 3544). The PWS handles all liquid waste that contains trace amounts of radioactivity, heavy metals, and organics or that which has the potential to be contaminated with these constituents.

\subsubsection{Strategy}

An overview of th: program strategy for LLLW, process waste, and area sources is depicted in Fig. 3.16. Figure 3.17 summarizes both the existing and proposed facilities and 
Table 3.4. Line item and general plant projects for solid low-level waste facilities at Oak Ridge National Laboratory

\begin{tabular}{|c|c|c|}
\hline Title & $\begin{array}{c}\mathrm{TEC}^{a} \\
(\$ \times 1000)\end{array}$ & $\begin{array}{l}\text { Fiscal } \\
\text { year }\end{array}$ \\
\hline \multicolumn{3}{|l|}{ Line item project } \\
\hline Bulk Contaminated Soil Facility & 1,800 & 1991 \\
\hline $\begin{array}{l}\text { Low-Level Waste Disposal Facilities } \\
\text { (Class L-I and L-II) }\end{array}$ & 140,000 & 1994 \\
\hline Interim Waste Management Facility (IWMF) II & 3,000 & 1997 \\
\hline \multicolumn{3}{|c|}{ General plant projects } \\
\hline SWSA 6 Improvements ${ }^{b}$ & 309 & 1990 \\
\hline SWSA 6 Staging Area Upgrade & 545 & 1990 \\
\hline Class L-III/IV Retrievable Storage Facilities & 1,100 & 1991 \\
\hline Class L-III/IV Aboveground Storage Facility & 481 & 1992 \\
\hline Solid Low-Level Waste Staging Facility & 760 & 1994 \\
\hline IWMF Upgrade & 500 & 1995 \\
\hline Class L-III/IV Retrievable Storage Facilities & 1,100 & 1995 \\
\hline SWSA 7 Aboveground Storage Facility & 1,100 & 1996 \\
\hline
\end{tabular}

actions, the details of which are described separately later. The functional areas used for strategy development are outlined in the left column: generation, waste transfer/operational monitoring control, waste collection, waste treatment, waste disposal/discharge, and environmental monitoring/permitting.

The LLLW System and the PWS treat contributions from generators, surface water, and groundwater. Strategy is being developed to meet the objectives of improved control of contaminated surface water and groundwater as well as to improve control of processes that generate waste. Connections between the liquid waste systems are being modified to improve system operations and to better meet regulatory requirements.

\subsubsection{Liquid Low-Level Waste System}

The LLLW System is an assemblage of tanks, associated transfer pipelines, and ancillary equipment (e.g., pumps and evaporators) designed for collecting, neutralizing, concentrating, and storing wastes prior to disposal. The bulk of the LLLW tanks and transfer lines are buried underground or are in concrete vaults for purposes of radiation shielding.

The LLLW System was designed to handle waste solutions with maximum activity of $20 \mathrm{Ci} / g a l$. However, current WAC limits influents to $2 \mathrm{Ci} / \mathrm{gal}{ }^{90} \mathrm{Sr}$ equivalent and $<100 \mathrm{nCi} / \mathrm{g}$ of alpha-emitting transuranic elements. Surveys of NG materials sent to the system seem to indicate that these solutions do not contain significant quantities of 
ORNL-OWG $91 \mathrm{M}-14677 R 7$

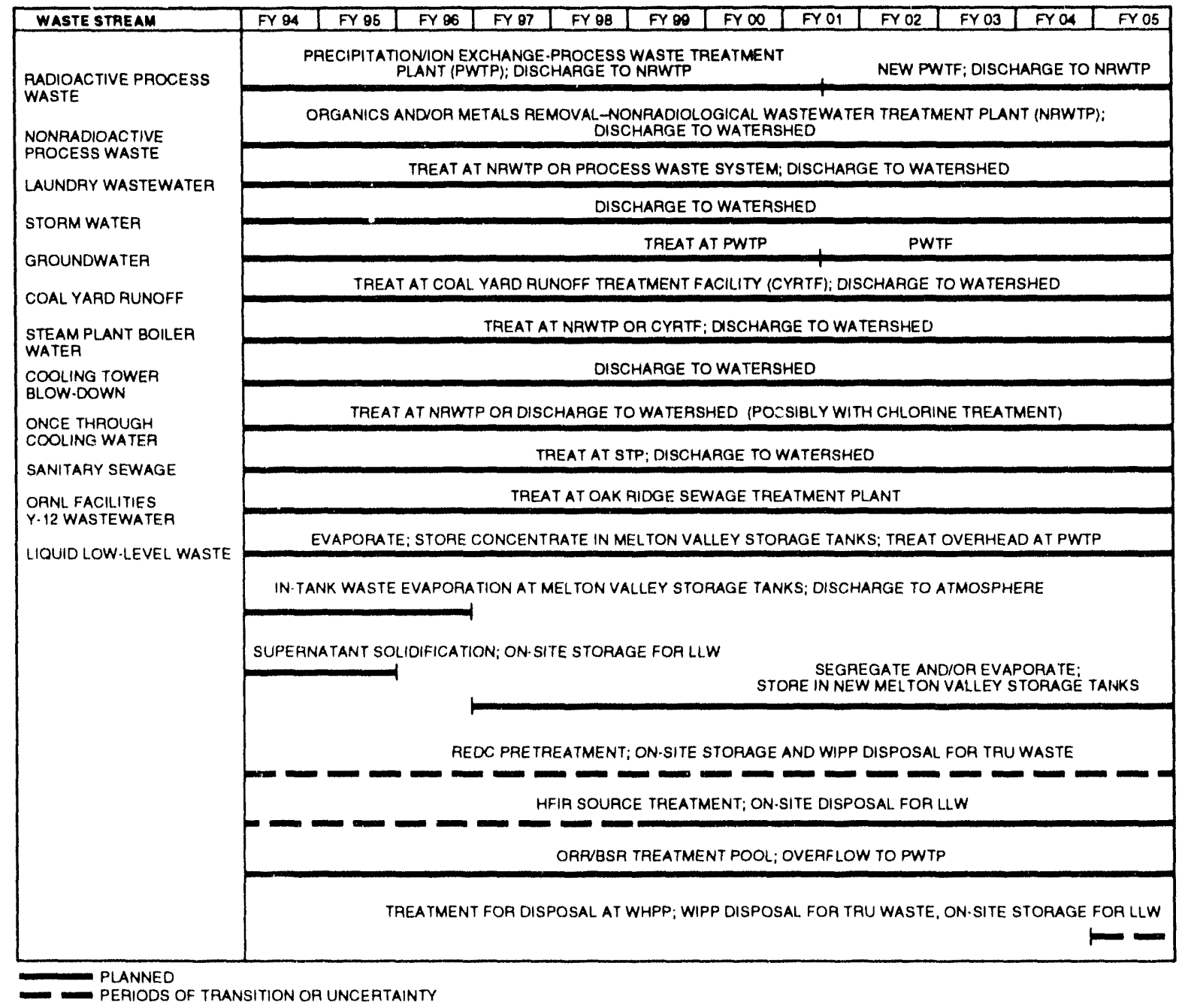

Fig. 3.16. Liquid waste management strategy.

hazardous chemicals. However, both past and current waste treatment and storage practices (e.g., waste neutralization and evaporation) have produced LLLW concentrates and sludges containing concentrations of hazardous chemicals high enough to be subject to regulatory controls (i.e., RCRA LDRs for mixed wastes).

The active LLLW System may be viewed as containing eight major subsystems:

- small tanks and lines, located in/near individual source building, used for initial accumulation or transfer of LL.LW;

- waste-collection vehicles that serve a few facilities (i.e., containerized waste and tank truck capabilities);

- intermediate collection tanks and lines in the main ORNL Complex in Bethel Valley for collection and transfer (CAT) of wastes received from the accumulation subsystem to a central waste collection header $(\mathrm{CWCH})$;

- four intermediate collection tanks and transfer lines in the Melton Valley Area that discharge to a central pumping station: 
ORAR-DWG 91M-14041R3

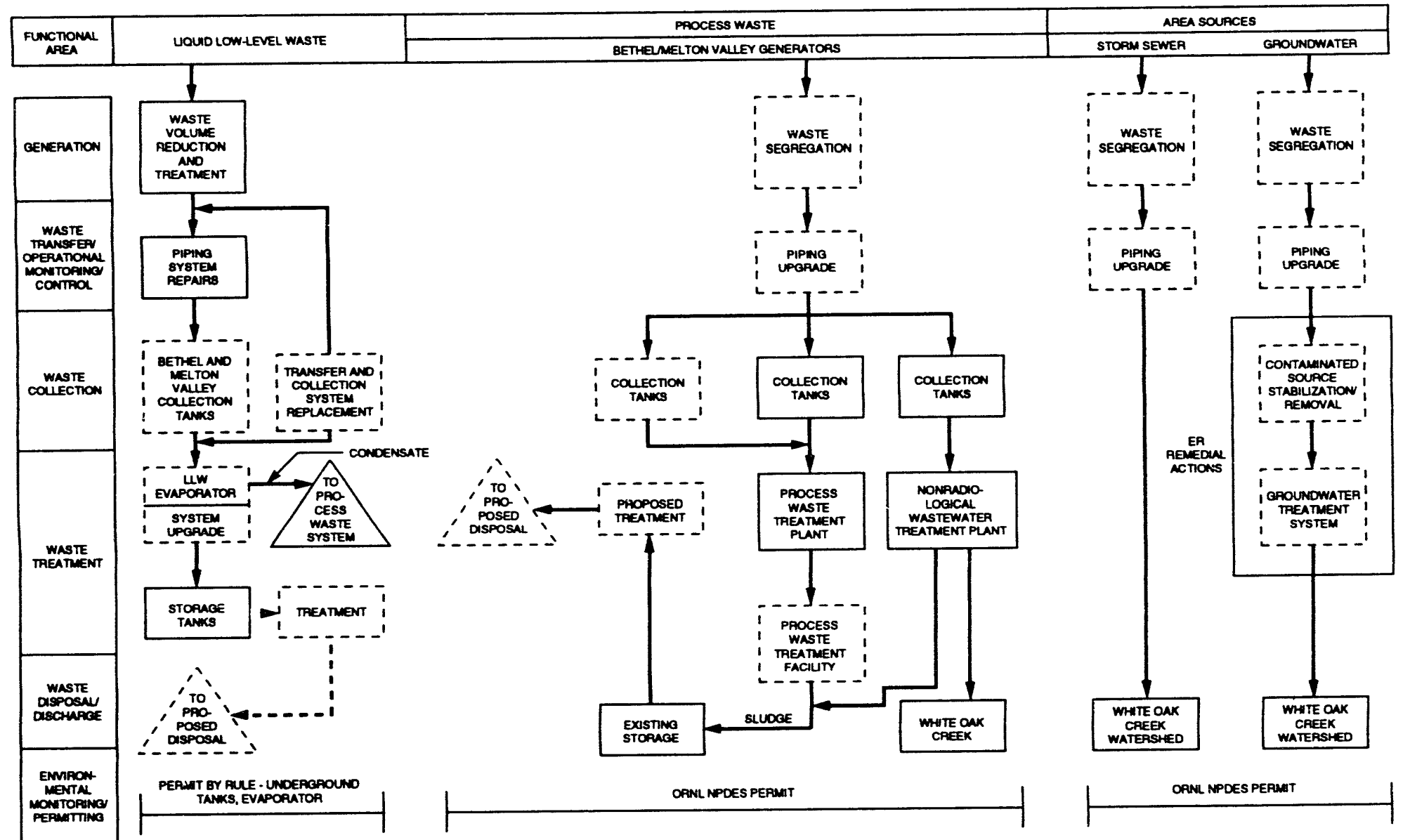

- - PROPOSED. PLAMUED, OR IN CONSTRUCTION FACUUTY OR ACTION

Fig. 3.17. Existing and proposed facilities for liquid low-level waste, process waste, and area sources. 
- a Melton Valley pumping station and a transfer line that transfer LLLW received from the four intermediate collection tanks to the CWCH in the main ORNL Complex;

- a CWCH that receives LLLW from the intermediate collection tanks in the main ORNL Complex and from the Melton Valley pumping station and, in turn, transfers the wastes to the evaporator facility (Building 2531);

- waste evaporators and their associated service and storage tanks (five tanks in all); and

- eight tanks located near the NHF that represent the principal storage site for evaporator concentrates.

Disposal of waste concentrates on-site is not currently possible because concerns about potential releases and changing regulatory requirements forced shutdown of the ORNL hydrofracturing process in 1984. The stored concentrates are to be processed in WHPP and disposed of off-site. Interim measures (including waste minimization and building new storage tanks as necessary) are being implemented to ensure that adequate storage volume is maintained until treatment capabilities become available. Development work is proceeding in parallel for treatment of legacy and NG wastes at alternative treatment facilities should WHPP be significantly delayed or canceled.

The system receives LLLW from 32 source buildings (including 4 in the Melton Valley Area) via local accumulation tanks and/or bottling or trucking transfers. Transfer piping (typically unvalved) connects these components with one or more of the stainless steel collection tanks [1892- to 56,781 - L capacity (500- to 15,000 -gal), median $<7570 \mathrm{~L}$ $(2000 \mathrm{gal})]$ that are still in service. Each collection tank currently in service is equipped with liquid-level instrumentation and a filtered vent to the atmosphere or to the Off-Gas System of the facility that it serves. Wastes are neutralized in the collection tanks and periodically transferred (by pump or steam jet) to the doubly contained, stainless steel $\mathrm{CWCH}$. The LLLW is directed through this header to one of the $189,270-\mathrm{L}(50,000$-gal), stainless steel evaporator service tanks (located in an underground, stainless steel-lined concrete vault), which serves as a feed tank to the LLLW evaporator.

The LLLW evaporators are centrally located in the main ORNL Complex in Bethel Valley. Waste from Melton Valley collection tanks is first transferred to a local pumping station. A singly contained transfer line conducts the LLLW from that point, over Haw Ridge, and into the main ORNL Complex. Waste concentrates from the evaporators are transferred through doubly contained, stainless steel piping either to storage tanks located near the evaporator [189,270-L (50,000-gal) stainless steel, underground in concrete vault] or to one of the MVSTs [eight 189,270-L (50,00n-gal) stainless steel, underground in stainless steel-lined concrete vault].

\subsubsection{Generic description and characteristics of waste}

\section{Liquid low-level waste}

Several facilities at ORNL contribute to the generation of LLLW. The radioactive liquid waste generated at ORNL can be categorized into several types of waste: (1) liquid secondary wastes that are a result of gaseous and PWTP operations, (2) wastes that result from decontamination of hot cells and various areas, and (3) R\&D process-generated wastes. Of these types of LLLW, gaseous and water treatment facility operations wastes have accounted for $\sim 11 \%$ of the dilute LLLW generated in 1993. Decontamination and R\&D activities have generated $\sim 36 \%$ of the waste, and rainwater/groundwater infiltration account for the remaining $53 \%$ of the dilute LLLW generation. 
Major generators of dilute LLLW include the 3039 off-gas scrubber, HFIR (Building 7900), the PWTP, and the REDC (Building 7920) (Table 3.5). In addition, leakage of rainwater and groundwater into the LLLW System accounts for $\sim 50 \%$ of the waste volume collected. Annual LLLW generation is on the order of $1.7 \times 10^{6} \mathrm{~L}\left(4.5 \times 10^{5} \mathrm{gal}\right)$. The major generators of concentrated LLLW are the PWTP, HFIR, and the REDC (Table 3.6). Over $99 \%$ of the activity entering the LLLW System is generated by the REDC. The only other generator that produces significant quantities of radionuclides is HFIR. The majority of the TRU isotopes ${ }^{90} \mathrm{Sr}$ and ${ }^{137} \mathrm{Cs}$ were generated at the REDC. Most of the ${ }^{192} \mathrm{Ir}$ is generated by the HRLEL (Building 3525). HFIR generated the majority of the ${ }^{60} \mathrm{Co}$ and ${ }^{3} \mathrm{H}$. The primary contributors of dissolved solids to the LLLW were the PWTP, HFIR, and the REDC. These results are particularly important because the dissolved solids content and amount of dilute LLLW fed to the evaporator during a given run are the primary factors that determine the efficiency of the LLLW evaporator. Approximately 49,210 to $98,421 \mathrm{~L}$ $(\sim 13,000$ to $26,000 \mathrm{gal})$ of concentrate are being stored each year for future treatment and disposal.

In the past, the isotope facilities at ORNL were used primarily for producing and distributing various radionuclides. A wide range of radionuclides were handled. Major activities at the facilities included tritium processing, ${ }^{85} \mathrm{Kr}$ enrichment, short-lived fission products processing, ${ }^{137} \mathrm{Cs}$ and ${ }^{90} \mathrm{Sr}$ source fabrication, ${ }^{60} \mathrm{Co}$ storage, ${ }^{99} \mathrm{Tc}$ processing, and some TRU isotope processing. Most processing operations stopped in 1990. In the Isotopes Area very little LLLW is now generated as a direct result of processing activities. Most of the waste production is a result of routine and nonroutine hot-cell decontamination. The primary radionuclides expected to be in the waste streams generated from these facilities are ${ }^{137} \mathrm{Cs},{ }^{90} \mathrm{Sr},{ }^{131} \mathrm{I},{ }^{152} \mathrm{Eu}$, and ${ }^{154} \mathrm{Eu}$. Waste generation decreased with the Isotopes Area shutdown in 1990 but will increase owing to decontamination efforts in the foreseeable future.

The scrubbing operation for the Central Off-Gas Collection System (stack 3039) produces a spent caustic solution that is slightly radioactively contaminated. The 3039 Stack Area produces $\sim 151,400 \mathrm{~L} /$ year $(40,000$ gal/year) of dilute LLLW and accounts for $\sim 10 \%$ of the total LLLW collected each year.

LLLW collected from HFIR is generated primarily from the following sources: (1) regeneration and backwashing of primary and pool demineralization systems, (2) waste from sampling, and (3) head tank overflow. When HFIR was shut down, the LLLW generation rate was $\sim 10,220 \mathrm{~L} /$ month $(\sim 2700 \mathrm{gal} / \mathrm{month})$. When in operation, the system is the largest single generator of dilute LLLW at ORNL. During HFIR operations the most significant LLLW generation source is the regeneration and backwashing of the primary and pool demineralization systems. In 1992 these regeneration solutions accounted for $\sim 378,500 \mathrm{~L}(\sim 100,000 \mathrm{gal})$ of LLLW generated during the year and also represented the primary source of ${ }^{60} \mathrm{Co}$ in the LLLW System at ORNL. During 1993, processing problems occurred that have caused an increase in the number of regenerations, and the LLLW generated increased to $529,400 \mathrm{~L}(140,000 \mathrm{gal})$.

Dilute LLLW generation in the REDC has decreased each year since 1991, going from $64,352 \mathrm{~L} /$ year $(17,000 \mathrm{gal})$ to $41,640 \mathrm{~L} /$ year $(11,000 \mathrm{gal})$ in 1993. This decrease is a result of process improvements. The majority of the volume is the spent caustic solution from the facility's off-gas scrubber.

The PWTP contributes the fifth largest volume to the dilute LLLW stream at $\sim 41,640 \mathrm{~L} /$ year $(\sim 11,000 \mathrm{gal})$ and also contributes significantly to the LLLW concentrate. This waste stream is a result of regeneration of the ion exchange columns at the PWTP.

Rainwater and groundwater inleakage, pump prime water, etc.-all grouped under "nonprogrammatic waste" in Table 3.5-make up the largest dilute LLLW stream. 
Table 3.5. Dilute liquid low-level waste (LLLW) generation: 1992 and 1993

\begin{tabular}{|c|c|c|c|c|c|}
\hline \multirow[b]{2}{*}{ Tank } & \multirow{2}{*}{ Building $^{\circ}$} & \multicolumn{2}{|c|}{$\begin{array}{l}\text { Yearly generation } \\
\text { L (gal)/year }\end{array}$} & \multicolumn{2}{|c|}{ Percent of total } \\
\hline & & 1992 & $1993^{b}$ & 1992 & 1993 \\
\hline WC-10 & $3028.3029^{*} .3030-32,3038,3039.3047^{*}, 3093$ & $11,356(3,000)$ & $8,328(2,200)$ & 1 & $<1$ \\
\hline WC-19 & Bldgs. $3001^{*}$ (OGR), 3042 (ORR), $3119(\mathrm{BSR})^{c}$ & $15,142(4.000)$ & $4,542(1,200)$ & 1 & $<1$ \\
\hline 2026 & Bldg. $2026^{*}$ & $10,221(2,700)$ & $13,627(3,600)$ & 1 & 1 \\
\hline WC-20 & Bldgs. $7920^{*} .7930$ (REDC) $^{c}$ & $49.210(13,000)$ & $41.640(11,000)$ & 3 & 2 \\
\hline HFIR & Bldg. $7900^{*}(\mathrm{HFIR})^{c}$ & $459,549(121.400)$ & $529,958(140,000)$ & 31 & 30 \\
\hline WC-7 & Bldg. $3504^{*}$ & $2.006(530)$ & $454(120)$ & $<1$ & $<1$ \\
\hline W-16 & Bldg. $3026 \mathrm{D}^{*}$ & $2,082(550)$ & $2,650(700)$ & $<1$ & $<1$ \\
\hline WC-3 & Bldg. $3025^{*}$ & $2.590(420)$ & $6,435(1.700)$ & $<1$ & $<1$ \\
\hline \multirow[t]{2}{*}{ W-22 } & PWTP Feed*c & $47,696(12,600)$ & $40.882(10,800)$ & 3 & 2 \\
\hline & 3039 stack* & $147.253(38,900)$ & $163,530(43,200)$ & 10 & 9 \\
\hline$N-71$ & Bldg. 3019* & $1.363(360)$ & $1.136(300)$ & $<1$ & $<1$ \\
\hline $\begin{array}{l}S-324 . S-223 \\
\text { and } S-523\end{array}$ & Bldg. $3517^{*}$ & $1.540(400)$ & $0(0)$ & $<1$ & $<1$ \\
\hline \multirow[t]{2}{*}{ Trucked } & Bldg. 3074* & $7,192(1,900)$ & $6,435(1,700)$ & $<1$ & $<1$ \\
\hline & Bldg. $3525^{*}$ & $4.921(1,300)$ & $6.435(1.700)$ & $<1$ & $<1$ \\
\hline Bottled & $\begin{array}{l}\text { Bldgs. } 3026 \mathrm{C}^{*}, 3047^{*}, 3592^{*}, 4500 \mathrm{~N}^{*}, 4500 \mathrm{~S}^{*} \text {, } \\
4501^{*}, 4508^{*}, 1505^{*}\end{array}$ & $212(56)$ & $772(204)$ & $<1$ & $<1$ \\
\hline \multirow[t]{2}{*}{ Various $^{d}$} & $\begin{array}{l}\text { Nonprogrammatic waste (e.g., sumps. filter pits. } \\
\text { inleakage) }\end{array}$ & $732.629(193.540)$ & $931,060(245,960)$ & 49 & 53 \\
\hline & & $1,505.292(397,656)$ & $1,757,885(464,384)$ & & \\
\hline
\end{tabular}

"Only those facilities with an asterisk were generating LLLW in 1993.

"Data for 1993 estimated based on 1993 generator surveys and information available January througher Radiochemical Engineering Development Center (REDC),

cOak Ridge Graphite Reactor (OGR). Oak Ridge Reactor (ORR), Bulk Shieldin

High Flux lsotope Reactor (HFIR), and Process Waste Treatment Plant (PWTP). $18.927 \mathrm{~L}(5,000$ gal) during 1993 from inactive tank 7562. 
Approximately 757,082 to $946,353 \mathrm{~L} /$ year $(\sim 200,000$ to 250,000 gal) are treated as LLLW. This number varies greatly depending on the amount of rainfall received in the year. It accounts for $\sim 50 \%$ of the collected dilute LLLW; however, a high-volume reduction factor is achieved for this waste stream, and the resulting volume of concentrate is estimated as $<1893 \mathrm{~L} /$ year ( $<500 \mathrm{gal} /$ year) $(\sim 2 \%$ of the concentrate collected in a typical year).

\section{TRU-contaminated liquid low-level waste}

The REDC recovers a variety of radiochemicals produced by irradiation of selected isotopes. The LLLW produced at the REDC [ 41,600 L/year $(\sim 11,000 \mathrm{gal})$ in 1993] is primarily generated from disposal of spent off-gas scrubber solutions. The scrubber solutions typically contain low levels of radioactivity. A waste minimization effort was undertaken in FY 1992 to change the scrubber operation to reduce the total LLLW generation rate at the REDC. In addition, small volumes of LLLW are generated as a direct result of isotope processing from operations conducted at the REDC. Although volumes are small, the REDC is the major contributor of the TRU isotopes ${ }^{90} \mathrm{Sr}$ and ${ }^{137} \mathrm{Cs}$ and the mixed-fission-product concentration in the system. The existing LLLW System does not have provisions for segregating and handling TRU-contaminated liquids separately. Modification of the LLLW System to isolate TRU-contaminated liquid waste is currently being studied.

\section{Concentrated liquid low-level waste}

Liquid low-level waste is concentrated in one of two evaporators at the LLLW Complex. (See Subsect. 3.2.2.2 for a brief description of the facility). The resulting LLLW concentrate is then stored prior to final treatment and/or disposal. Table 3.6 lists the estimated volumes of concentrate resulting from the evaporation of LLLW from the various facilities.

Table 3.6. Liquid low-level waste concentrate generation: 1992 and 1993

\begin{tabular}{|c|c|c|c|c|}
\hline \multirow{2}{*}{ Generator } & \multicolumn{2}{|l|}{1992} & \multicolumn{2}{|l|}{1993} \\
\hline & $\mathrm{L}(\mathrm{gal}) /$ year & Percent & L (gal)/year & Percent \\
\hline Process Waste Treatment Plant & $43,532(11,500)$ & 67 & $42,018(11,100)$ & 56 \\
\hline High Flux Isotope Reactor & $9,464(2,500)$ & 15 & $23,848(6,300)$ & 32 \\
\hline $\begin{array}{l}\text { Radiochemical Engineering } \\
\text { Development Center }\end{array}$ & $7,192(1,900)$ & 11 & $6,057(1,600)$ & 8 \\
\hline $\begin{array}{l}\text { Oak Ridge Reactor/Bulk } \\
\text { Shielding Reactor }\end{array}$ & $757(200)$ & 1 & $0(0)$ & 0 \\
\hline Building 3517 & $<379(<100)$ & $<1$ & $0(0)$ & 0 \\
\hline Building 3525 & $<379(<100)$ & $<1$ & $<757(<200)$ & $<1$ \\
\hline Isotopes Area & $<379(<100)$ & $<1$ & $<757(<200)$ & $<1$ \\
\hline Others & $3,028(800)$ & 5 & $2,271(600)$ & 3 \\
\hline Total & $65,109(17,200)$ & & $89,500(23,600)$ & \\
\hline
\end{tabular}


An average of 68,137 to $94,635 \mathrm{~L}(18,000$ to 25,000 gal) of LLLW concentrate are produced each year. The PWTP is currently the largest contributor, generating an estimated $42,018 \mathrm{~L} /$ year $(11,000 \mathrm{gal})$ for 1993. HFIR is the second largest generator at 20,063 L/year (5300 gal), and the REDC is expected to produce $\sim 6057 \mathrm{~L}(\sim 1600 \mathrm{gal})$ of concentrate during 1993. The rest of the generators contribute the remaining $4 \%$ of the LLLW concentrate.

The PWTP is the largest generator of LLLW concentrate. During 1992 and 1993, 67 and $56 \%$, respectively, of the total LLLW concentrate generated was attributed to PWTP operations. HFIR generated 15 and $32 \%$ of the LLLW concentrate in 1992 and 1993 respectively. The third largest generator is the REDC. All other facilities combined generated less than $10 \%$ of the LLLW concentrate.

\subsubsection{Treatment facilities}

Facilities associated with the LLLW System at ORNL consist of collection tanks and piping, a service tank at Building 2531, the evaporator facilities at Building 2531, evaporator storage tanks, and Melton Valley storage tanks. With the exception of these storage tanks (Subsect. 3.2.2.3), the remaining facilities are considered as treatment facilities and are discussed in this subsection.

The waste accumulated in the collection tanks is transferred via underground piping to the LLLW Evaporator Facility (Building 2531) where it is concentrated in one of the two evaporator units that operate at an average volume reduction factor of $30: 1$. The concentrated waste is then transferred to one of several storage tanks, and the evaporator condensate is transferred to the PWTP for further treatment. Figure 3.18 shows a schematic of the LLLW System.

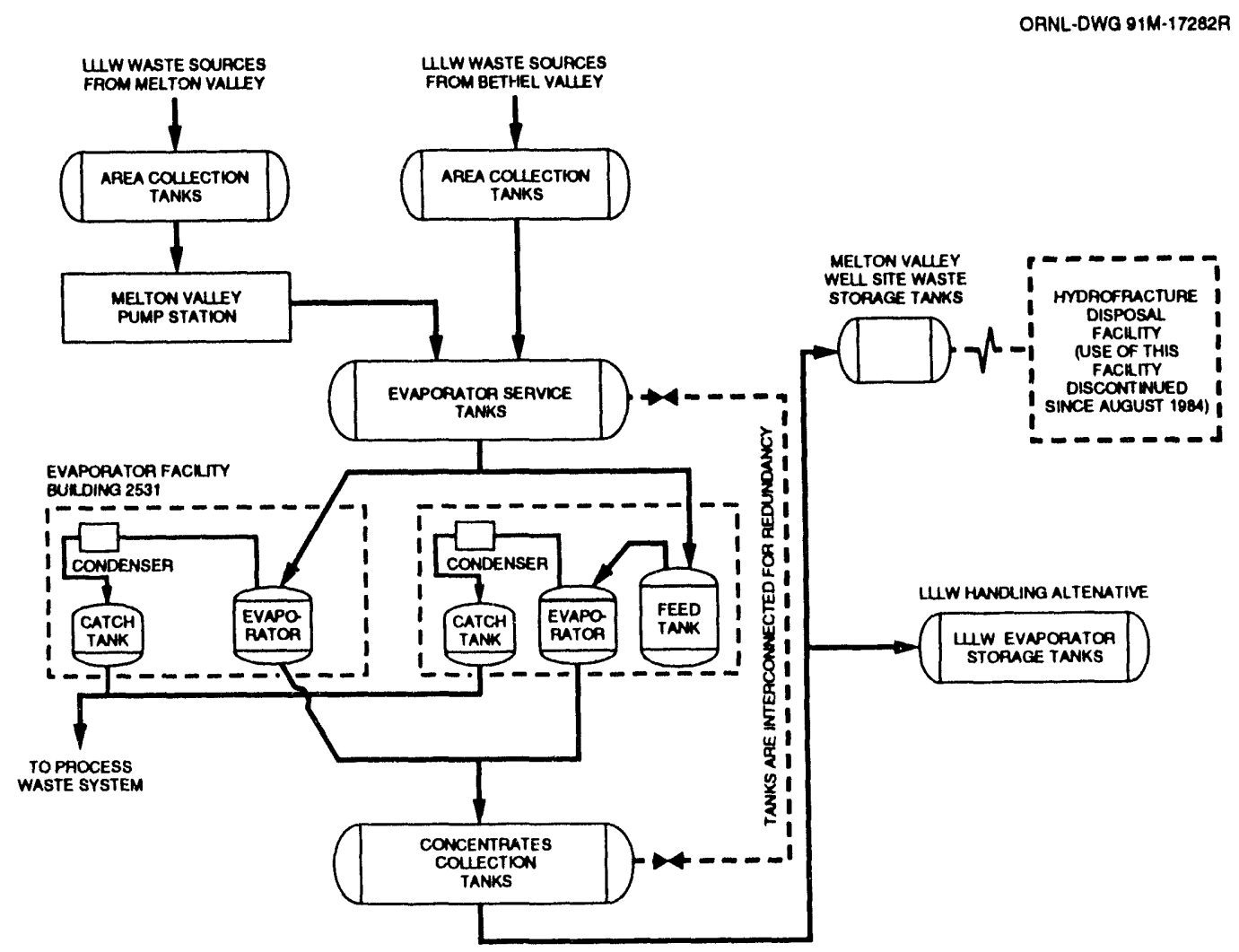

Fig. 3.18. Liquid Low-Level Waste System description. 
ORNL's LLLW Tank System is divided into two areas: Melton Valley and Bethel Valley. Currently, 40 active collection tanks are used: 10 serve the Melton Valley area, 17 serve the Bethel Valley area, and 13 are associated with the central treatment/storage system. Also, 56 collection and storage tanks are currently inactive: 39 are owned by the ERP; 17 are owned by WMRAD or the generating division. The locations of the active tanks are shown in Fig. 3.19. The capacities of the active collection tanks in Bethel and Melton Valleys are given in Table 3.7. The 13 concentrate storage tanks are shown in Table 3.8 in relation to other parts of the LLLW System.

Most of the floor drains, collection tanks, and transfer lines in the system are singly contained. Most of the tanks associated with the centralized treatment system are doubly contained. The system was designed to work $\sim 30$ years; however, most of the system has surpassed its design life. LLLW solutions that accumulate in the collection tanks are periodically transferred to the Central Treatment/Storage System as shown in Figs. 3.17, 3.18 , and 3.19. The waste is collected in the evaporator service tank W-22 (Fig. 3.20) and then fed to evaporators $\mathrm{A} 2$ and $2 \mathrm{~A} 2$ for processing. One of the two evaporators is operated in a semicontinuous manner. The second evaporator is an in-place spare. Dilute LLLW is transferred by steam jet from feed tank W-22, as necessary, to maintain an operating level in the evaporator where the waste is concentrated to a target specific gravity of greater than 1.25. The evaporator condensate, which contains traces of radionuclides, is directed to the PWTP. When the evaporator bottoms or concentrated waste reaches a specific gravity between 1.25 and 1.5, or when no feed is left to process, the evaporator is shut down, the contents are cooled, and the "concentrate" is transferred via steam jet to one of four storage tanks (i.e., W-21, W-23, C-1, or C-2) and then pumped to W-24 through W-28. The transfer of the concentrate from the evaporator facility to the storage tanks is accomplished through a doubly contained stainless steel line that is cathodically protected and leak-tested before each transfer.

Major areas of the Radioactive Waste Evaporator Facility (Building 2531) (see the plan view in Fig. 3.21) include:

- Three separate stainless steel-lined vaults containing (1) the evaporator feed tank W-22 and the converted evaporator feed tank W-21 (now a storage tank for concentrated liquid waste generated by the PWTP); (2) the concentrate storage tank W-23; and (3) associated pumps, pipes, and controls.

- An underground pipe trench. This is used for the transfer of liquid waste from feed tank W-22 to the evaporator and concentrate to W-23 or W-21.

- The tank vault containing tanks C-1 and C-2. These are storage tanks for concentrated waste from the evaporator.

- Cells 1 through 4 in Building 2531 that contain the evaporators and associated equipment. Cell 1 contains the original evaporator A-2 and its feed tank, A-1. Cell 2 contains the accompanying evaporator (A-2) process equipment, which includes a condenser, vapor filter, condensate catch tank, off-gas scrubber, emergency condenser, and scrub liquor tank. Cell 4 holds evaporator $2 \mathrm{~A}-2$, and cell 3 contains the condensate filter, evaporator condenser, condensate surge tank, off-gas scrubber, and the scrub liquor tank for evaporator $2 \mathrm{~A}-2$.

\section{Environmental monitoring}

Monitoring of outfalls specified in the National Pollutant Discharge Elimination System (NPDES) permit began in April 1986. The condensate from the LLLW evaporators is treated for removal of small quantities of radionuclides at the PWTP and is mixed with 

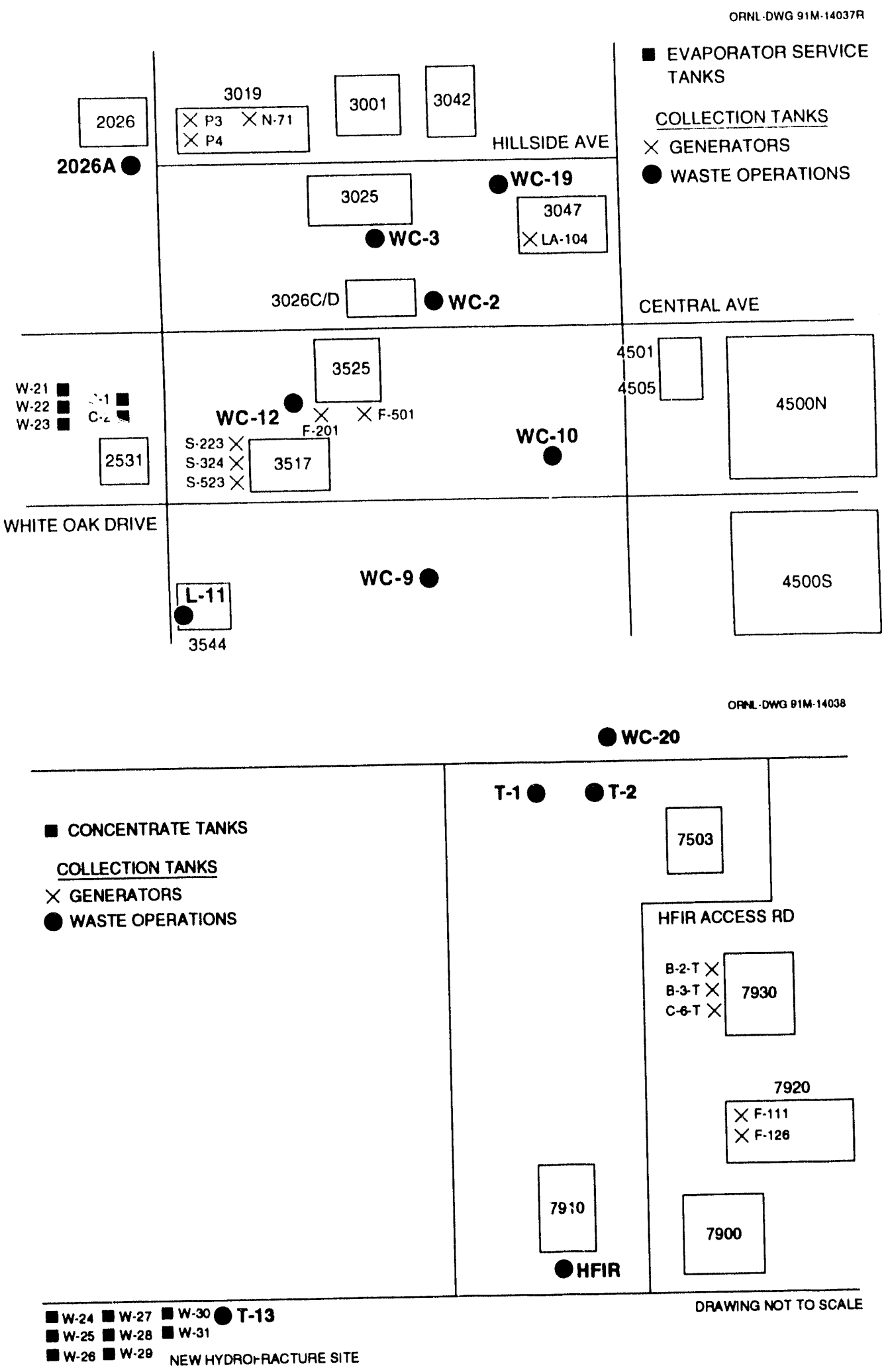

Fig. 3.19. Location of Waste Management Operation's active liquid low-level waste collection tanks. 
Table 3.7. Liquid low-level waste active collection tank capacities and source buildings at Oak Ridge National Laboratory

\begin{tabular}{|c|c|c|}
\hline Tank & $\begin{array}{l}\text { Capacity } \\
{[\mathrm{L} \text { (gal)] }}\end{array}$ & Source building(s) \\
\hline \multicolumn{3}{|c|}{10 Melton Valley collection tanks } \\
\hline $\mathrm{T}-13$ & $15,141(4,000)$ & NHF \\
\hline$B-2-T$ & $7,878(1,870)$ & 7930 \\
\hline$B-3-T$ & $7,878(1,870)$ & 7930 \\
\hline $\mathrm{C}-6-\mathrm{T}$ & $2,649(700)$ & 7930 \\
\hline$F-111$ & $473(125)$ & 7920 \\
\hline$F-126$ & $4,542(1,200)$ & 7920 \\
\hline WC-20 & $37,854(10,000)$ & 7920 \\
\hline HFIR & $49,210(13,000)$ & $7900,7911,7913$, and 7922 \\
\hline$T-1$ & $56,781(15,000)$ & $7900,7911,7913$, and 7922 \\
\hline $\mathrm{T}-2$ & $56,781(15,000)$ & $7900,7911,7913$, and 7922 \\
\hline \multicolumn{3}{|c|}{18 Bethel Valley collection tanks } \\
\hline $2026 \mathrm{~A}$ & $1,893(500)$ & 2026 \\
\hline WC-2 & $3,785(1,000)$ & 3028,3038 \\
\hline WC-3 & $3,785(1,000)$ & $3025 \mathrm{E}, 3025 \mathrm{M}$ \\
\hline WC- $7^{a}$ & $4,163(1,100)$ & 2533 and 2534 drain lines, 3504 \\
\hline WC-9 & $8,100(2,140)$ & Hot off-gas pot \\
\hline WC-10 & $7,571(2,000)$ & $3028-3033,3039,3047$, and 3093 \\
\hline WC- 19 & $8,517(2,250)$ & $3001,3002,3109,3042$, and 3119 \\
\hline$W-16^{\circ}$ & $3,785(1,000)$ & $3026 \mathrm{D}$ \\
\hline$N-71$ & $908(240)$ & 3019 \\
\hline$P-3$ & 746 (197) & 3019 \\
\hline P-4 & $746(197)$ & 3019 \\
\hline S-223 & $9,463(2,500)$ & 3517 \\
\hline S-324 & $3,785(1,000)$ & 3517 \\
\hline S-523 & $3,785(1,000)$ & 3517 \\
\hline$L-11$ & $1,514(400)$ & PWTP \\
\hline$F-201$ & $189(50)$ & 3525 \\
\hline F-501 & $757(200)$ & 3525 \\
\hline
\end{tabular}

No longer in use. 
Table 3.8. Liquid low-level waste concentrate storage tank capacities and waste volumes

\begin{tabular}{|c|c|c|}
\hline Tank & $\begin{array}{l}\text { Capacity } \\
{[\text { L (gal)] }}\end{array}$ & $\begin{array}{l}\text { Volume stored } \\
\qquad[\mathrm{L}(\mathrm{gal})]^{a}\end{array}$ \\
\hline \multicolumn{3}{|c|}{ Melton Valley storage tanks } \\
\hline W-24 & $189,270(50,000)$ & $150,673(39,808)$ \\
\hline$W-25$ & $189,270(50,000)$ & $156,078(41,236)$ \\
\hline W-26 & $189,270(50,000)$ & $158,292(41,821)$ \\
\hline W-27 & $189,270(50,000)$ & $156,025(41,222)$ \\
\hline W-28 & $189,270(50,000)$ & $162,350(42,893)$ \\
\hline W-29 & $189,270(50,000)$ & $172,293(45,520)$ \\
\hline W-30 & $189,270(50,000)$ & $170,704(45,100)$ \\
\hline W-31 & $189,270(50,000)$ & $159,814(42,223)$ \\
\hline \multicolumn{3}{|c|}{ Bethel Valley evaporator service/storage tanks } \\
\hline$W-21^{b}$ & $189,270(50,000)$ & $90,197(23,830)$ \\
\hline$W-22$ & $189,270(50,000)$ & $75,889(20,050)^{c}$ \\
\hline W-23 & $189,270(50,000)$ & $106,774(28,210)$ \\
\hline$C \cdot 1$ & $189,270(50,000)$ & $103,936(27,460)$ \\
\hline $\mathrm{C}-2$ & $189,270(50,000)$ & $173,694(45,890)$ \\
\hline Total & $2,460,518(650,000)^{d}$ & $1,836,720(485,263)$ \\
\hline
\end{tabular}

\footnotetext{
${ }^{a}$ Volumes of concentrate stored as of October 1, 1993.

${ }^{b}$ Tank $W-21$ is currently receiving concentrated waste from the Process Waste Treatment Plant.

${ }^{c}$ Since $\mathrm{W}-22$ is a service tank with fluctuating volumes, an average of $40 \%$ of the total capacity is shown as the volume stored.

"This is the total capacity of the tanks. The operating capacity is $2,337,492 \mathrm{~L}(617,500 \mathrm{gal})$.
}

other waste streams and treated at the Nonradiological Wastewater Treatment Plant (NRWTP) before being discharged to White Oak Creek (WOC) through an NPDES discharge point. Each collection tank in the LLLW System is equipped with a sampling device, liquid-level instrumentation, and a filtered vent to the atmosphere or to the off-gas system of the facility that it serves. Underground collection tanks in the Bethel Valley area have "dry wells," which are concrete pads with sumps located at the low point, and wells extending to the surface of the ground where groundwater is sampled to identify tank leakage.

Waste volume can be reduced through maximizing waste treatment efficiency by improved monitoring and control. System operations are enhanced by centralized monitoring at the Waste Operations Control Center (WOCC). When capital projects are implemented to upgrade the LLLW CAT System, instrumentation will be added for both monitoring and controlling the ORNL LLLW Systems from WOCC. In addition, WOCC computers are used to generate reports and to manipulate data. 


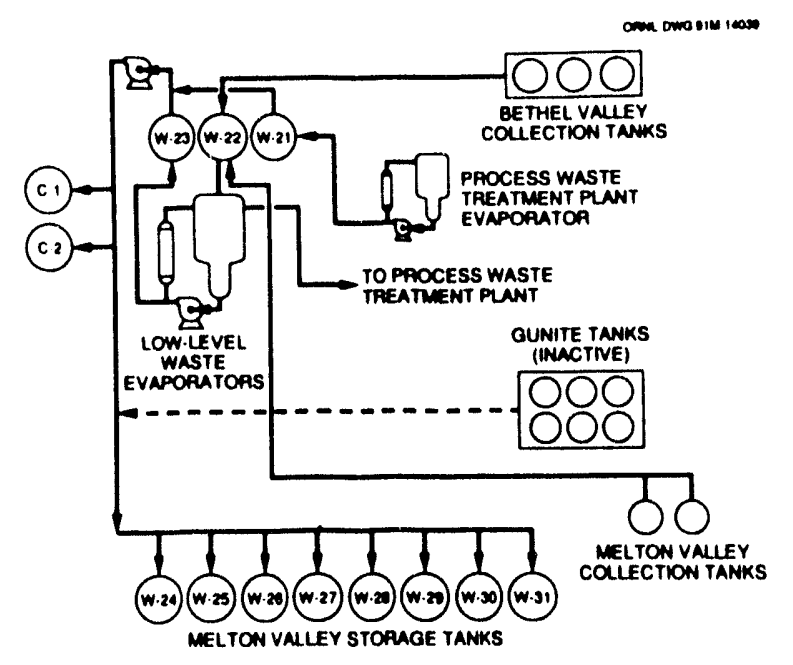

Fig. 3.20. Liquid Low-Level Waste Collection, Treatment, and Storage System.

The ORR Federal Facilities Agreement (FFA) has called for instrument upgrades and leak test plans. In addition, further enhancements of instrumentation include correction of generator tank instruments to WOCC.

As required by Sect. IX.F.4 of the FFA, Waste Management has initiated testing of the active, singly contained (Category C) tank systems at ORNL. During FY 1993, tanks WC-3, WC-, and WC-9 were tested monthly. Tanks WC-10 and W-16 were added to the monthly testing schedule in September. Two large tanks [>11,356 L (3,000 gal)] were monitored and assessed frequently during FY 1993 to develop a lead-testing method for large tanks. These two tanks (i.e., T-1 and T-2) will be added to the monthly testing schedule in FY 1994. Demonstrations were completed on both pressurized pipelines and gravity-fed pipelines during FY 1993 in order to develop a test method for each type of pipeline. Pipeline testing will be initiated in FY 1994.

\section{Permitting status}

The RCRA permit-by-rule was updated in 1991 for unit operations that produce a waste stream monitored at an NPDES discharge point. Therefore, all LLLW collection, treatment, and solidification systems (active and inactive) are currently under the RCRA permit-by-rule (Subsect. 3.2.2.3).

\section{Facility status}

The primary treatment for LLLW is evaporation; two evaporators (one of mid-1960s design and the other of mid-1970s design) are currently in use. Both are functioning; however, replacement of the evaporators has been planned because the newer evaporator has developed leaks in three of seven coils, and the older evaporator is nearing the end of its design life. Replacement of the newer vessel is ongoing.

Treatment of acid waste generated by ion exchange demineralizers is being reviewed for various sites at ORNL. At present, these wastes are treated at the Central LLLW Evaporator System. These high-nitrate, acidic wastes generated by the demineralizer systems cause problems in the LLLW Treatment System that increase the total concentrate 




Fig. 3.21. Plan view of the Evaporator Facility Complex (Building 2531).

generation rate because (1) caustic neutralization adds additional salts to the LLLW System, (2) nitrates are difficult to handle in disposal processes, and (3) both parameters negatively impact the effectiveness of the central evaporator to concentrate LLLW.

The LLLW CAT upgrades include installing equipment for more precise measurement and control of the amount of caustic needed to neutralize LLLW in the collection tanks. This procedure will reduce dissolved solid content of LLLW.

The major generators of concentrated LLLW are shown in Table 3.6. REDC operations are being evaluated for possible upgrades to reduce the amount of LLLW, particularly TRU components and dissolved solids generated at the facility.

A proposed FY 1994 GPP will install pretreatment systems at the REDC (Building $7920)$ to reduce or to eliminate LLLW. The REDC is a significant contributor of LLLW $(8 \%)$ and the main contributor of TRU $(99 \%)$ in the LLLW System.

\subsubsection{Storage facilities}

Currently, LLLW concentrate is being accumulated and stored in MVSTs and Bethel Valley tanks. ORNL has $12189,270-\mathrm{L}(50,000$-gal) tanks utilized for the storage of LLLW 
concentrate. Eight of these tanks, known as the MVSTs, are located at the NHF site in an underground concrete, stainless steel-lined vault. The other four storage tanks, located near the LLLW Evaporator Facility, are C-1, C-2, W-21, and W-23. Both C-1 and C-2 receive LLLW concentrate. W-21, originally a feed tank for the LLLW evaporator, was converted to a tank for storage of concentrate produced by the PWTP in an effort to decouple the PWTP and LLLW operations. Currently, tank W-22 serves as the sole evaporator feed tank. Tank W-23 receives concentrate directly from the evaporator and is normally used as a collection point for LLLW concentrate before it is transferred to the MVSTs for storage. The design capacities and current waste volume for these tanks are listed in Table 3.8.

\section{Environmental monitoring}

Each storage tank is either equipped with a sampling device, liquid-level instrumentation, and a filtered vent to the atmosphere or connected to off-gas systems (i.e., blowers, filters, etc.) and maintained under negative pressure. Underground storage tanks in Melton Valley are contained in stainless steel vaults equipped with sumps and level detectors located at the low points to identify and to handle tank leakage.

\section{Permitting status}

Operation of the LLLW System is governed by the requirements in several DOE orders as well as regulations of the EPA and the TDEC. Although some components of the ORNL LLLW System handle or store mixed wastes, the system is currently exempt (via an RCRA permit-by-rule applicable to NPDES-pernitted wastewater treatment systems) from the technical standards (e.g., integrity testing, leak detection, secondary containment) and permitting requirements of RCRA. However, RCRA land disposal restriction regulations will apply to LLLW concentrates. See Sect. 5 on mixed wastes for details.

The ORR (including ORNL) was placed on the Superfund National Priorities List by the U.S. Environmental Protection Agency (EPA) on December 21, 1989. The Superfund Amendments and Reauthorization Act of 1986 (SARA) requires that DOE execute an FFA with the EPA in order to establish schedules for compliance with Superfund requirements. The FFA was signed in November 1991 and became effective on January 1, 1992.

In addition to the more typical Superfund requirements (e.g., schedules for remedial investigations at contaminated sites), the ORR FFA provisions also established additional compliance requirements specific to the ORNL LLLW System (Environmental Restoration Agreement for the Oak Ridge Reservation). This action has been undertaken voluntarily by DOE-ORO in response to EPA concerns that the ORNL system, even though technically exempt from most RCRA standards, should be subject to equivalent requirements because of the hazardous nature of the radioactive wastes being handled.

During the course of negotiations for the ORR FFA, the EPA, working with DOEORO and the TDEC, has incorporated interim compliance requirements for the LLLW System. These requirements include (1) integrity assessments including leak testing and inspections for all LLLW tanks, transfer lines, and ancillary equipment; (2) removal from service, along with corrective action, for leaking components; and (3) leak detection and secondary containment for all new or replacement tank systems.

The FFA defines four generic categories of tank systems: (1) new or replacement tank systems, (2) tank systems having secondary containment, (3) tank systems not having secondary containment, and (4) tank systems that have been removed from service. The FFA tank listing that has been submitted to DOE and the regulatory authorities is given in Table 3.9. Thirty-nine of the LLLW tanks are inactive (i.e., do not receive LLLW and are 
isolated, either physically or administratively, from active waste generating facilities). The FFA requirements for these tanks will be met through the ERP. The remaining 57 tanks are owned by WMRAD or the generating divisions. They are currently either active LLLW tanks or tanks that have been permanently removed from service and will be transferred to the ERP in the near future.

The impact of the FFA to the active LLLW System is shown in Table 3.9. Nine tanks (i.e., W-11, 4501-C, 4501-D, 3002A, T-14, S-424, WC-4, LA-104, and 4501-P) were removed from service prior to the FFA signing because they were no longer being used. Tanks 4001-C and 4001-D have been remediated; the remainder will be transferred to ERP. Nine tanks (i.e., W-17, W-18, WC-5, WC-6, WC-8, WC-11, WC-12, WC-13, and WC-14) were removed from service when the FFA was signed because the tank systems are known or are suspected to leak (inleak or outleak). W-12 is being repaired, and permission from the TDEC is being sought to restore it to service. Tanks W-16, WC-10, and WC-2 will be used for near-term decontamination activities (i.e., 1991-1997 or later) and will then be removed from service. The W-21 through W-31, C-1, C-2, and T-13 tanks are expected to meet secondary containment standards without upgrades. The remaining tank systems will be upgraded/replaced to comply with the new regulations. Five tank systems (i.e., WC-10, WC-19, T-1, T-2, and HFIR) are considered to be environmental, safety, and health (ES\&H) tank systems that cannot be immediately shut down without creating unacceptable ES\&H risks. Potential ES\&H waste streams include those from regeneration of ion exchange columns at shutdown reactors, decontamination of shutdown hot cells, and other decontamination activities for the Isotope Area Facilities and the Graphite Reactor Canal. Table 3.10 summarizes the facilities that have access to tank systems that were operational.

\section{Facility status}

Designed primarily in the 1950s, the ORNL LLLW System was given an expected operating life of approximately 30 years, but much of the system is older. The five tanks and transfer lines associated with the ORNL evaporator facility are of late 1960s to late 1970s vintage, the CWCH dates to around 1980, and the MVSTs and WC-20 in Melton Valley, along with their transfer piping, were installed in the late 1970s. Most of these newer components of the LLLW System have leak detection and secondary containment capabilities that appear to permit continued operation with little or no modification.

In contrast, most of the building drains, collection tanks (all but WC-20 in the Melton Valley Area), and transfer lines (upstream from the central collection header in Bethel Valley except the Melton Valley transfer line north and south of Haw Ridge and some of the newer lines above the pumping station in the Melton Valley) are singly contained, and some are in questionable condition.

A procedure known as in-tank evaporation (ITE) is being utilized to reduce the amount of liquid waste stored in the MVSTs. Each of the eight storage tanks has a tank ventilation system for purging gases from the tanks as well as submersed air sparges used to mix the contents of the tanks. In the ITE scheme, dry air is being introduced into the tanks and will ideally exit the tanks in a saturated state. ITE has been implemented for 15 months and evaporated $77,457 \mathrm{~L}(20,462 \mathrm{gal})$ in the first year of operation. It has the capability to process NG waste to avoid an increase in storage tank volumes until the saturation limits of the salt components (predominately $\mathrm{NaNO}_{3}$ ) in the storage tanks are reached. Preliminary estimates indicate that approximately $30 \%$ of the volume in the MVSTs can be evaporated without precipitating these materials. The primary reason for this activity is to ensure that LLLW storage space remains available until additional storage capacity is available. However, it does not have the capability to work off inventory, to address emptying of ERP 
Table 3.9. Federal Facilities Agreement (FFA) requirements for Oak Ridge National Laboratory Liquid Low-Level Waste (LLLW) Tank System

\begin{tabular}{|c|c|c|c|c|c|c|c|c|c|}
\hline \multicolumn{4}{|c|}{ Existing tank systems with secondary containment } & \multicolumn{6}{|c|}{ Existing tank systems without secondary containment } \\
\hline \multicolumn{2}{|c|}{$\begin{array}{l}\text { Not requiring upgrades } \\
\text { or repiacements }\end{array}$} & \multicolumn{2}{|c|}{$\begin{array}{l}\text { Requiring upgrades } \\
\text { or replacements }\end{array}$} & \multicolumn{2}{|c|}{$\begin{array}{l}\text { Requiring } \\
\text { replacements }\end{array}$} & \multicolumn{4}{|c|}{ Removed from service } \\
\hline Tank & $\begin{array}{l}\text { Facility } \\
\text { served }\end{array}$ & Tank & $\begin{array}{l}\text { Facility } \\
\text { served }\end{array}$ & Tank & $\begin{array}{l}\text { Facility } \\
\text { served }\end{array}$ & Tank $^{a}$ & $\begin{array}{l}\text { Facility } \\
\text { served }\end{array}$ & $\operatorname{Tank}^{b}$ & Tank $^{b}$ \\
\hline $\begin{array}{l}\text { C-1 } \\
\text { C-2 } \\
\text { W-21 } \\
W-22 \\
W-23 \\
W-24 \\
W-25 \\
W-26 \\
W-27 \\
W-28 \\
W-29 \\
W-30 \\
W-31 \\
T-13\end{array}$ & $\begin{array}{l}\text { LLLW Evap. } \\
\text { LLLW Evap. } \\
\text { LLLW Evap. } \\
\text { LLLW Evap. } \\
\text { LLLW Evap. } \\
\text { LLLW Evap. } \\
\text { LLLW Evap. } \\
\text { LLLW Evap. } \\
\text { LLLW Evap. } \\
\text { LLLW Evap. } \\
\text { LLLW Evap. } \\
\text { LLLW Evap. } \\
\text { LLLW Evap. } \\
\text { NHF }\end{array}$ & 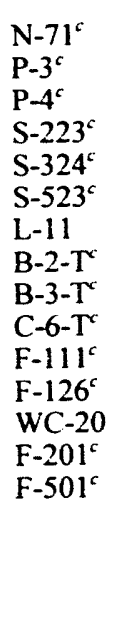 & $\begin{array}{l}3019 \\
3019 \\
3019 \\
3517 \\
3517 \\
3517 \\
\text { PWTP }^{\text {REDC }} \\
\text { RED }^{h} \\
\text { REDC } \\
\text { REDC } \\
\text { REDC } \\
\text { REDC } \\
\text { REDC } \\
3525 \\
3525\end{array}$ & $\begin{array}{l}2026 \mathrm{~A} \\
\text { WC-3 } \\
\text { WC-9 } \\
\text { WC-7 } \\
\text { HFIR } \\
\text { T-1 } \\
\text { T-2 } \\
\text { WC-10 } \\
\text { WC-2 } \\
\text { WC-19 } \\
\text { W-16 } \\
\text { W-12 }\end{array}$ & $\begin{array}{l}2026 \\
3025 \\
\text { HOG pot } \\
2533,3504 \\
\text { HFIR } \\
\text { HFIR } \\
\text { HFIR } \\
\text { Isotopes } \\
\text { Isotopes } \\
\text { ORR, BSR } \\
\text { 3026D } \\
3525\end{array}$ & $\begin{array}{l}3002 A \\
\text { WC-4 } \\
\text { W-11 } \\
\text { WC-5 } \\
\text { WC-6 } \\
\text { WC-8 } \\
\text { S-424 } \\
\text { WC-11 } \\
\text { WC-12 } \\
\text { WC-13 } \\
\text { WC-14 } \\
4501-P^{c} \\
\text { T-14 } \\
\text { W-17 } \\
\text { W-18 } \\
\text { LA-104 }\end{array}$ & $\begin{array}{l}3002 \\
3026 \mathrm{D} \\
3028 \\
3508 \\
3508 \\
\text { Inactive } \\
3517 \\
4500 \\
4500 \\
4500 \\
4500 \\
4501 \\
\text { Inactive } \\
3026 \mathrm{C} \\
3026 \mathrm{C} \\
3047\end{array}$ & $\begin{array}{l}3001-B \\
3001-S \\
3003-A \\
3004-B \\
3013 \\
\text { WC-1 } \\
\text { TH-4 } \\
\text { TH-1 } \\
\text { TH-2 } \\
\text { TH-3 } \\
\text { H-209 } \\
\text { W-19 } \\
\text { W-20 } \\
\text { WC-15 } \\
\text { WC-17 } \\
\text { T-30 } \\
7560 \\
7562 \\
7503-A\end{array}$ & $\begin{array}{l}\text { W-1 } \\
\text { W-13 } \\
\text { W-14 } \\
\text { W-15 } \\
\text { W-1A } \\
\text { W-2 } \\
\text { W-3 } \\
\text { W-4 } \\
\text { T1 } \\
\text { T2 } \\
\text { T3 } \\
\text { T4 } \\
\text { T9 } \\
\text { W-10 } \\
\text { W-11 } \\
\text { W-5 } \\
\text { W-6 } \\
\text { W-8 } \\
\text { W-9 } \\
\end{array}$ \\
\hline
\end{tabular}

${ }^{a}$ Waste Management Division.

${ }^{b}$ Environmental Restoration Division.

GGenerator-owned tanks.

${ }^{d}$ HOG-hot off-gas pot.

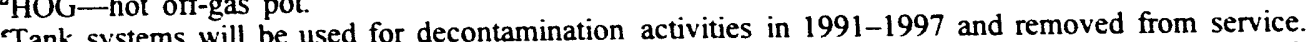

Tank systems will be used for decontan of wastes for environmental, safety, and health reasons only.

sProcess Waste Treatment Plant.

${ }^{h}$ Radiochemical Engineering Development Center.

'Oak Ridge Research Reactor, Bulk Shielding Reactor.

Has been taken out of service for repairs.

New Hydrofracture Facility. 
Table 3.10. Facilities supported by active liquid low-level waste tanks ${ }^{a}$

\begin{tabular}{ll}
\multicolumn{1}{c}{ Facility } & \multicolumn{1}{c}{ Tank } \\
\hline Building 3019 & N-71, P-3, P-4 \\
Building 3517 & S-223, S-324, S-523 \\
Evaporator complex & C-1, C-2, W-21 through W-31 \\
Building 3544 & L-11 \\
New Hydrofracture Facility & T-13 \\
Radiochemical Engineering & B-2-T, B-3-T, C-6-T, F-111, F-126, WC-20 \\
Development Center & F-201, F-501 \\
Building 3525 & WC-10, WC-2, W-12 ${ }^{b}$ \\
Isotopes Circle & HFIR, T-1, T-2 \\
High Flux Isotope Reactor & WC-19 \\
Oak Ridge Research Reactor & WC-19 \\
Bulk Shielding Reactor & WC-19 \\
Oak Ridge Graphite Reactor & WC-3 \\
Building 3025 & WC-7 \\
Buildings 2533 and 3504 & WC-9 \\
Hot off-gas pot & $2026 A$ \\
Building 2026 & W-16 \\
Building 3026D & \\
\hline
\end{tabular}

${ }^{a}$ After the Federal Facilities Agreement became effective on January 1, 1992, tanks WC-2, W-16, and WC-10 could only receive waste from decontamination activities for Isotopes Facilities shutdown.

${ }^{b}$ This tank has been repaired, and the TDEC is reviewing restoration of the tank to service.

or evaporator service tanks, or to cover emergency-generated waste. Out-of-tank evaporation is also being considered for implementation to enhance ITE.

Projects currently identified to deactivate and/or to upgrade ORNL LLLW CAT System tanks and piping, together with various filter pit upgrades, are described in the following subsections.

Bethel Valley LLLW CAT System upgrade. This FY 1988 LI project will include LLLW System upgrades to collect radioactive liquid waste from sources within generating facilities in the Bethel Valley area of ORNL. The existing system must be modified to comply with provisions of the FFA, which require double containment, integrity testing, capability for leak detection, cathodic protection, and other safety features. Phase I of this project included construction of a Monitoring Control Station (Building 2099) and upgrades to the LLLW internal and external piping for the HRLAL (Building 2026), construction of a new Transported Waste Receiving Facility (Building 2649); construction of a new waste 
transfer line for the Central Off-Gas Facility (Building 3092), and upgrade of the instrumentation in the WOCC (Building 3130) to provide remote monitoring and control capability. Phase II of this project includes construction of a Monitoring Control Station (Building 3611) and upgrades to the LLLW internal and external piping for the HRLEL (Building 3525) as well as upgrade of the instrumentation in the WOCC (Building 3130) to provide remote monitoring and control capability for these facilities. Activities accomplished as of FY 1993 under Phase I include 99\% completion of the Monitoring Control Station, the external piping and the internal piping for hot cells 1 through 4 in Building 2026, completion of the waste transfer line for the Central Off-Gas Scrubber Facility (Building 3092), and $\sim 95 \%$ completion of the Transported Waste Receiving Facility (Building 2649).

Melton Valley LLLW CAT System upgrade. This FY 1992 LI will upgrade the LLLW CAT System for HFIR (Building 7900) and the REDC (Buildings 7920 and 7930) in Melton Valley. The project work will include upgrade and replacement of internal and

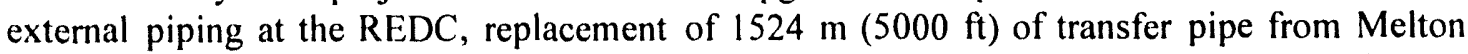
Valley to Bethel Valley, construction of a new monitoring and control station to provide holdup and treatment prior to pumping to Bethel Valley, and addition of a new ion exchange system for HFIR drains to eliminate the generation of LLLW. The Title I/II Design continued during FY 1993.

Bethel Valley FFA upgrades. This FY 1994 LI project will upgrade several facilities to meet FFA requirements by installing doubly contained piping and tanks, active leak detection, and corrosion protection for underground elements. The project will upgrade the internal and/or external LLLW CAT System for the hot off-gas pot and Buildings 2533, $2534,2537,3525$, and $3025 \mathrm{E}$. Current plans are to initiate the project design early in FY 1994 and construction in FY 1995. All work is scheduled to be completed by the end of FY 1997.

MVST capacity increase. This FY $1994 \mathrm{LI}$ will provide tanks with $1,703,435 \mathrm{~L}$ $(450,000 \mathrm{gal})$ of working capacity in Melton Valley to allow storage of LLLW from active and inactive programs and generator tanks that will be taken out of service by the FFA until treatment facilities can be built to process the wastes prior to disposal and will allow TRU segregation from LLLW.

FFA compliance-Building 3019A. This FY 1992 GPP will reroute Piping Systems that transport LLLW from Building 3019A to the Central Waste Evaporator System. The original Piping Systems are not in compliance with the FFA. These activities include the installation of doubly contained pipeline and valve box arrangements and cathodic protection and leak detection devices. The preliminary proposal was approved by DOE in July 1992, but design may not proceed until a NEPA determination has been made by DOE.

Building 3525-LLLW FFA upgrade. This FY 1992 GPP will reroute piping that transports LLLW from Building 3525 to the central Waste Evaporator System. The original Piping System is not in compliance with the FFA. The project activities include installation of doubly contained pipeline and valve box arrangements and cathodic protection and leak detection devices. Design was initiated on this project in April 1993. 
3108 filter pit enclosure. This 1993 GPP will add an enclosure over the 3108 filter pit for weather protection and contamination control. Design was initiated on this project in April 1993.

7930 filter pit cover. This proposed 1993 GPP will provide containment for the Transuranic Processing Plant area sump pits and filter pits to eliminate inleakage of groundwater and/or rainwater. Design was completed on this project in September 1993.

NHF filter pits upgrade. This proposed 1994 GPP will provide containment enclosures for cell plugs at the NHF to eliminate inleakage of groundwater and/or rainwater.

\subsubsection{Disposal facilities}

Currently, no routine, direct disposal option exists for LLLW, although hydrofracture has been used in the past. Hydrofracture is no longer considered an acceptable disposal option. Because the LLLW System sludges are TRU wastes under the DOE Order 5820.2A definition, LLLW sludges will be processed in the planned WHPP and disposed of off-site as RH TRU waste.

\subsubsection{Status of support systems}

\section{Training}

Management and supervision are responsible for ensuring that all division personnel receive training commensurate with their job assignments. Training requirements shall be established to ensure that job performance is accomplished in a manner that will provide a safe and healthv work environment for both the employee and companion employees. Training requirements must also be directed toward enhancement of the employee's ability to provide quality products or services.

\section{Certification}

A certification program has been completed for both LLLW and process waste streams at ORNL.

\section{Database management}

The WOCC computer-based monitoring system provides real time monitoring and historical data on the operation of the LLLW System at ORNL. The WOCC remotely monitors the operations of the evapcrator systems and also provides flow and level data, as well as some gross radioactivity measurements, in the LLLW Piping and Collection System. The WOCC receives and processes approximately 300 signals from field sensors including liquid levels and the conditions of active LLLW tanks.

\subsubsection{Line item and general plant projects}

A listing of proposed LI and GPPs for LLLW facilities at ORNL is provided in Table 3.11. This table indicates the project title, TEC, and the respective fiscal year for funding. 
Table 3.11. Line item and general plant projects for the Liquid Low-Level Waste System at Oak Ridge National Laboratory

\begin{tabular}{|c|c|c|}
\hline Title & $\begin{array}{c}\mathrm{TEC}^{a} \\
(\$ \times 1,000)\end{array}$ & $\begin{array}{l}\text { Fiscal } \\
\text { year }\end{array}$ \\
\hline \multicolumn{3}{|l|}{ Line item projects } \\
\hline $\begin{array}{l}\text { Bethel Valley Liquid Low-Level Waste (LLLW) Collection } \\
\text { Transfer (CAT) System Upgrade } \\
\text { - Phase I } \\
\text { - Phase II }\end{array}$ & $\begin{array}{l}35,000 \\
30,000\end{array}$ & $\begin{array}{l}1988 \\
1988\end{array}$ \\
\hline Melton Valley LLLW CAT System Upgrade & 41,000 & 1992 \\
\hline Bethel Valley Federal Facility Agreement (FFA) Upgrades & 20,500 & 1994 \\
\hline Melton Valley Storage Tank Capacity Increase & 48,000 & 1994 \\
\hline \multicolumn{3}{|c|}{ General plant projects } \\
\hline Oak Ridge Reactor/Bulk Shielding Reactor LLLW Upgrade & 1,100 & 1992 \\
\hline FFA compliance-Building 3019A & 1,085 & 1992 \\
\hline Building 3525-LLLW FFA Upgrade & 1,140 & 1992 \\
\hline 3108 Filter Pit Enclosure & 157 & 1993 \\
\hline 7930 Filter Pit Cover & 193 & 1993 \\
\hline $\begin{array}{l}\text { Pretreatment of Radiochemical Engineering Development } \\
\text { Center (Building 7920) LLLW }\end{array}$ & 1,100 & 1994 \\
\hline New Hydrofracture Facility Cell Plug Enclosure & 538 & 1994 \\
\hline
\end{tabular}

\subsubsection{Process Waste System}

Process wastes consist of liquid wastes that contain slight amounts of radioactive or hazardous materials or that may periodically be contaminated. Process wastes at ORNL include wastes collected from numerous laboratories and facilities in Bethel and Melton Valleys as well as condensate from the LLLW evaporators. However, the majority of liquid waste in the Process Waste System is groundwater intentionally drawn to sumps or pits and inleakage of underground piping. The general category of liquid waste can contain small quantities of radionuclides, metals, anions, and organics.

\subsubsection{Generic description and characteristics of waste}

As is previously discussed, the PWS is designed for waste streams that are potentially contaminated or that contain very low levels of contamination. The system primarily consists of a series of holding tanks and the PWTP, which is designed to remove radionuclides, and the NRWTP, which became operational in April 1990, to remove heavy metals and organics. In the PWS, wastewater from areas more likely to be contaminated with radioactivity are routinely processed through the PWTP, while other nonradiological waste streams that could potentially be contaminated with organics and heavy metals are routed to the NRWTP. Nonradiological wastewater is currently collected from the 4500 , 
2000,1500 , and the 6000 Areas. These streams are monitored for radioactivity and may be diverted to the PWTP should the radioactivity exceed an acceptable level. The PWTP effluent stream combines with the nonradiological waste streams for treatment at the NRWTP. The NRWTP effluent stream is discharged to WOC.

Waste from the 3000 Area is more likely to contain radioactive contaminants and is routinely processed through the PWTP. Each month $\sim 2.2 \times 10^{7} \mathrm{~L}\left(\sim 5.8 \times 10^{6} \mathrm{gal}\right)$ of contaminated process waste containing $40 \mathrm{nCi} / \mathrm{L}$ of gross beta activity are collected in the PWS at ORNL. A typical characterization of the process waste stream may consist of values such as pH of 7.5 , total hardness of $110 \mathrm{ppm}$, calcium hardness of $72 \mathrm{ppm}$, total alkalinity of $88 \mathrm{ppm}$, and total solids of $180 \mathrm{ppm}$. The generation of nonradiological process wastewater averages $\sim 2 \times 10^{7} \mathrm{~L} /$ month $\left(\sim 5.2 \times 10^{6} \mathrm{gal} / \mathrm{month}\right)$ resulting in a total average release of $4.2 \times 10^{7} \mathrm{~L} / \mathrm{month}\left(11 \times 10^{6} \mathrm{gal} /\right.$ month $)$ from the NRWTP.

\subsubsection{Treatment facilities}

Process waste is collected and treated at the PWTP for radionuclide removal and/or the NRWTP for organics and heavy metals removal. The current PWS is shown schematically in Fig. 3.22. Process wastewater that potentially contains small quantities of radionuclides from the 3000 Area is collected in the 946,353-L (250,000-gal) Bethel Valley storage tanks designated F-2101 and F-2102. Process wastewater from the 4500 Area normally drains to the collection/equalization tank F-1002 at the NRWTP. The 4500 Area wastewater is continuously monitored for radioactivity. If the water becomes contaminated, it is automatically diverted to the Bethel Valley storage tanks for treatment at the PWTP. Process wastewater generated in the Melton Valley Complex is collected in holding tanks. Unless the radioactivity level exceeds set limits, the contents of these tanks are normally discharged to NRWTP F-1002 tank. In the event that the radioactivity limits are exceeded, then the wastewater is pumped to the Bethel Valley storage tanks for treatment at the PWTP.

The PWTP is designed to remove radionuclides. The process flow diagram in Fig. 3.23 shows the processing steps such as softening, clarification, filtration, and ion exchange. The influent is treated by chemical softening, which removes nonradioactive calcium and magnesium as well as radioactive cations. The clarification and filtration steps are needed to remove the precipitated cations prior to ion exchange to avoid frequent column regeneration. The remaining small amount of radioactive material is removed from the waste by the ion exchange columns. The sludge from the clarifier is passed through a filter press to reduce the liquid content and is then packed in drums for SLLW on-site storage. A number of disposal alternatives are being considered for this waste stream. The concentrated radioactive material resulting from the regeneration of the PWTP ion exchange columns is currently evaporated to approximately $40 \%$ solids and transferred to the W-21 storage tank in the LLLW System. Nitric acid is recovered in this process and is recycled within the PWTP. The capacity of the PWTP evaporator requires that a portion of the regenerant solution be sent to the LLLW evaporator for treatment. A project titled Process Waste Treatment System Upgrade has been designed to increase the capacity of the PWTP Evaporator System; this will reduce the amount of LLLW concentrate generated for permanent disposal.

The volume of LLLW generated by the PWTP has been reduced by $80 \%$ since a clarifier/precipitator was installed in 1986. Reduction or elimination of this stream is important because the PWTP is the major contributor to the LLLW concentrate currently being stored for future disposal. Tank capacity is limited, and future treatment and disposal of this waste will be expensive. In addition, measures undertaken to reduce both intentional 


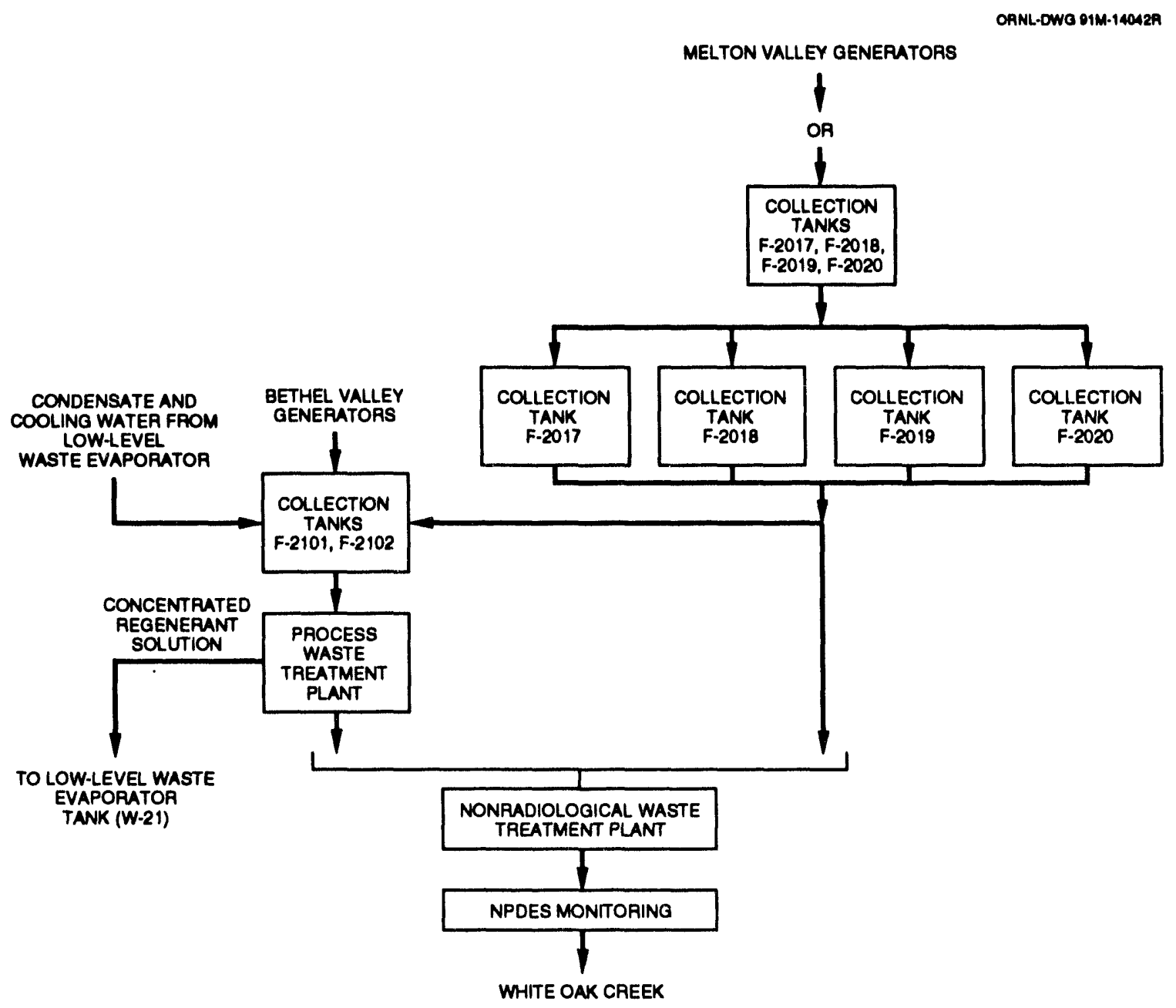

Fig. 3.22. Process Waste System.

and unintentional inleakage into the system through pipe lining or replacement would reduce the requirements on the PWTP.

Since April 1990, all process wastewater has also been treated in the new NRWTP, as required by the NPDES permit. The flow sheet shown in Fig. 3.24 consists of chemical precipitation, which removes heavy metals, air stripping, which removes volatile organics, and carbon columns, which remove nonvolatile organics. Since only a small percentage of the total influent wastewater to NRWTP requires metals removal, wastewater containing low concentrations of metals is diverted around the clarifier to reduce treatment costs and sludge production. The secondary waste (i.e., sludge and activated carbon) is being stored for disposal as solid low-level radioactive waste. A single NPDES discharge and monitoring point is maintained at the plant outfall and includes discharges from all ORNL process waste generators.

Since the NRWTP is a new facility, it meets existing regulatory and operational needs. However, the NPDES permit for the facility is renegotiated with the TDEC every 5 years. The NPDES permit issued to ORNL in 1986 allowed discharge limits for the NRWTP based on the Best Available Technology (BAT) for metal-plating industries. The NRWTP has complied with these discharge limits. NPDES permits are renegotiated every 5 years. The last permit expired in 1991, and ORNL and the TDEC are negotiating a new 
ORNL-DWG 91M-14040

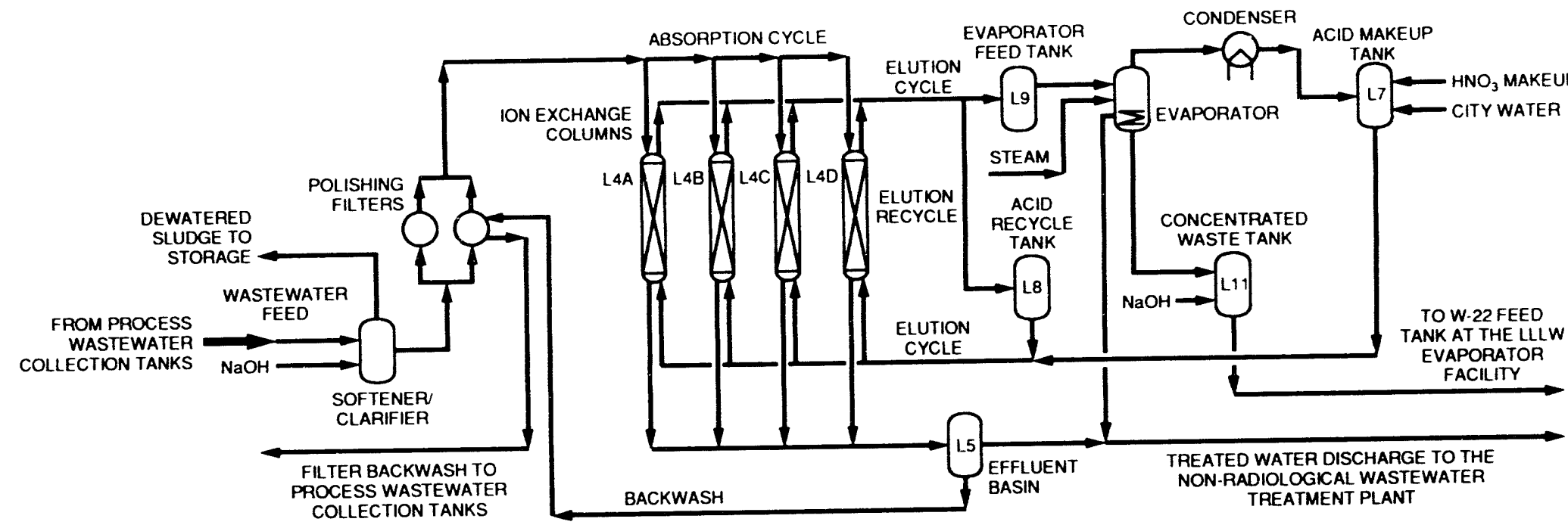

Fig. 3.23. Process flow diagram of the Process Waste Treatment Plant. 


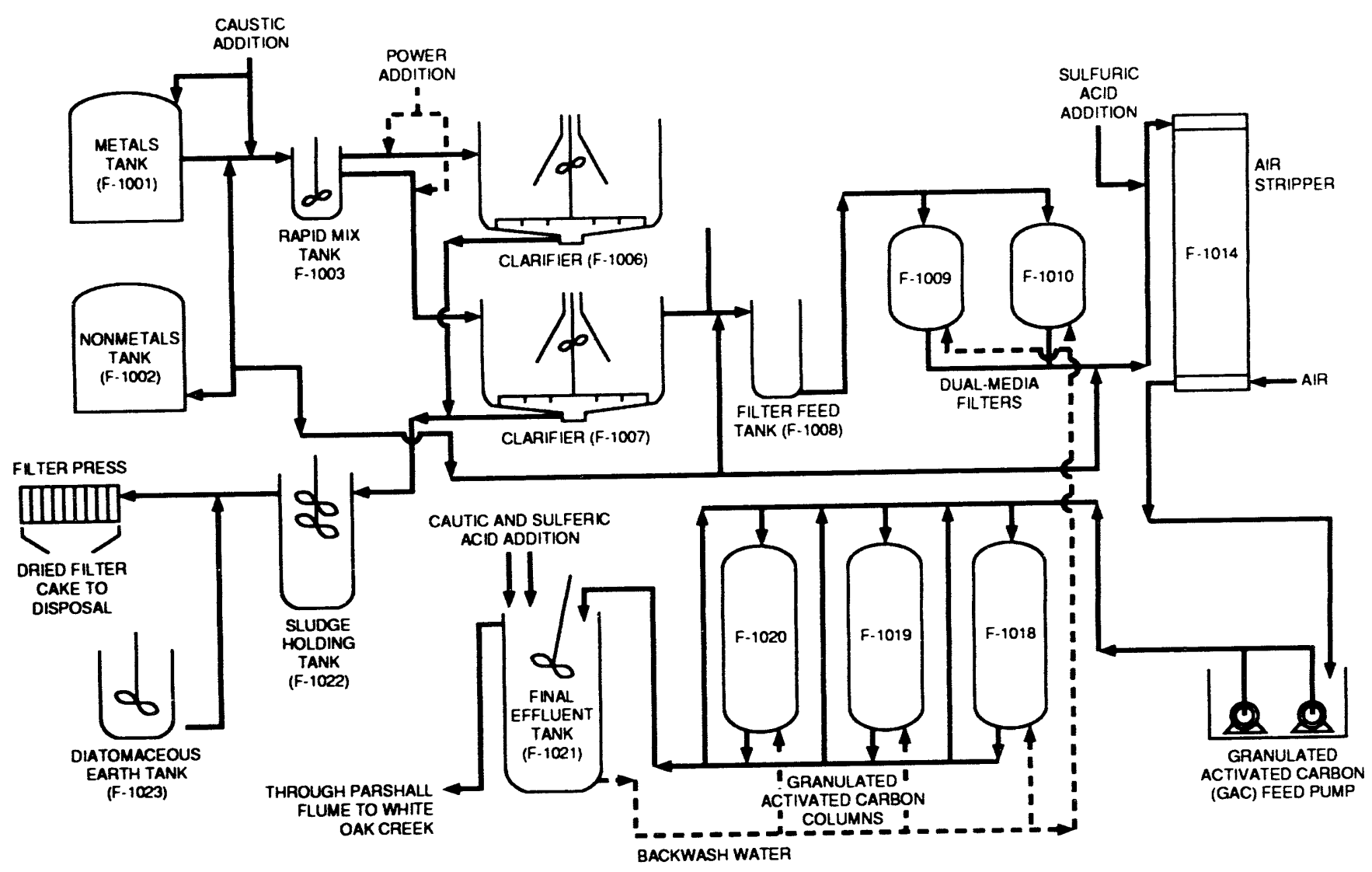

Fig. 3.24. Flow diagram of the Nonradiological Wastewater Treatment Plant. 
permit that is likely to be much more restrictive than the former permit. New NPDES permits nationwide are basing limits on Water Quality Standards (WQS) rather than BAT for the particular type industry. The discharge concentrations allowable are generally several orders of magnitude lower than BAT-based limits, particularly if the receiving stream into which the plant is discharging is low in total flow. Table 3.12 shows a comparison of the former NPDES permit limits and WQS.

Plant upgrades may be required to meet WQS-based NPDES permit limits. An environmental consulting firm was subcontracted to evaluate strategies for meeting the more restrictive limits. The principal alternatives identified were (1) implementation of plant upgrades designed to enhance removal of heavy metals, (2) relocation of the NRWTP discharge point to a larger receiving stream such as the Clinch River, (3) augmentation of the NRWTP effluent by pumping river water to the existing NRWTP discharge point, (4) evaluation of recvcle options for treated wastewater, and (5) assessment of site specific aquatic toxicity criterion that will prove that concentrations of pollutants higher than WQS are not toxic to aquatic life at the existing NRWTP discharge point. These strategies must undergo more detailed evaluation in order to choose the most feasible and cost-effective.

\section{Environmental monitoring}

Existing outfalls at ORNL include X01, Sewage Treatment Plant; X02, Coal Yard Runoff Facility; X12, Nonradiological Waste Treatment Plant; X13, Melton Branch; X14, White Oak Creek; X15, White Oak Dam; Category I, II, and III outfalls; cooling towers; and a number of miscellaneous outfalls. Each outfall is analyzed in accordance with DOE orders, NPDES permits, and RCRA requirements and noted in an activity field log. Field logs are used to document field measurements including flow, $\mathrm{pH}$, temperature, downstream $\mathrm{pH}$, and downstream temperature; some are used to document sample collection and include the type of sample (i.e., 24-h composite or grab), parameter sampled, and the time of sampling.

Data are collected on a daily, weekly, monthly, quarterly, and/or annual basis as required by the permit and recorded in a registered field log. The data gathered are keyed into a database that is utilized by statistical software and analyzed against the compliance requirements. Flow, temperature, and $\mathrm{pH}$ data are also extracted from the field logs and keyed into the database for electronic retrieval. Generalities used in analyzing the database are summarized herein. To report this data on the Form $2 \mathrm{C}$, the following criteria were applied: some pollutants were believed to be absent from the discharge and are excluded from water quality evaluation; and, for conservative purposes, values reported less than the detection limit were considered as the detection limit for calculation purposes.

Available water quality data for parameters monitored at each outfall were compiled into a statistical summary for each outfall. The summary, taken from data gathered for $\sim 2$ years, includes the number of samples, minimum value detected, maximum value detected, the mean, and the number of times the pollutant was detected. In instances where only one sample exists and the pollutant was not detected, the detection limit is noted as the minimum, the maximum, and the mean.

\section{Permitting status}

The PWS operates under RCRA permit-by-rule and is therefore exempt from RCRA permitting requirements. Current regulatory requirements for process waste generation can be categorized by RCRA waste minimization requirements, NPDES permit requirements, and DOE orders. When the 1984 Hazardous and Solid Waste Amendments to RCRA were written, Congress stipulated the requirements to report annually on waste minimization efforts but established no quantitative limits. ORNL will report activities that control waste 
Table 3.12. National Pollutant Discharge Elimination System permit limits vs Water Quality Standards"

\begin{tabular}{|c|c|c|c|c|c|}
\hline \multicolumn{3}{|c|}{ Former NPDES permit } & \multicolumn{2}{|c|}{$\begin{array}{l}\text { Water Quality } \\
\text { Standards }\end{array}$} & \multirow{2}{*}{ Comments } \\
\hline Parameter & $\begin{array}{l}\text { Monthly } \\
\text { avg. }\end{array}$ & $\begin{array}{l}\text { Daily } \\
\text { max. }\end{array}$ & Continuous & Max. & \\
\hline Flow, Mgd & $c$ & & & & \\
\hline Temperature, ${ }^{\circ} \mathrm{C}$ & & 30.5 & & 30.5 & \\
\hline Total suspended solids & 31.0 & 60.0 & & & \\
\hline Oil and grease & 10.0 & 15.0 & & & \\
\hline $\begin{array}{l}\text { Total toxic organic } \\
\text { compounds }\end{array}$ & & 2.13 & & & \\
\hline Cyanide & 0.65 & 1.2 & 0.0052 & 0.022 & Can comply \\
\hline Cadmium & 0.26 & 0.69 & 0.001 & 0.004 & $\begin{array}{l}\text { Compliance questionable. } \\
\text { Detection limit is } 0.005\end{array}$ \\
\hline Chromium & 1.71 & 2.77 & 0.10 & & Can comply \\
\hline Copper & 2.07 & 3.38 & 0.012 & 0.018 & Violations will occur \\
\hline Lead & 0.43 & 0.69 & 0.003 & 0.082 & $\begin{array}{l}\text { Compliance questionable. } \\
\text { Detection limit is } 0.05\end{array}$ \\
\hline Nickel & 2.38 & 3.98 & 0.158 & 1.418 & Can comply \\
\hline Silver & 0.24 & 0.43 & & 0.004 & $\begin{array}{l}\text { Compliance questionable. } \\
\text { Detection limit is } 0.005\end{array}$ \\
\hline Zinc & 1.48 & 2.61 & 0.106 & 0.117 & Violations will occur \\
\hline $\mathrm{BOD}_{s}{ }^{d}$ & $c$ & & & & \\
\hline Nitrate as $N$ & $c$ & & & & \\
\hline Sulfate as $\mathrm{SO}_{4}$ & $c$ & & & & \\
\hline Phosphorus & $c$ & & & & \\
\hline Phenol & $c$ & & & & \\
\hline Fluoride & $c$ & & & & \\
\hline Arsenic & $c$ & & 0.19 & 0.36 & Can comply \\
\hline Iron & $c$ & & & & \\
\hline Mercury & $c$ & & 0.00012 & 0.0024 & $\begin{array}{l}\text { Compliance questionable. } \\
\text { Detection limit is } 0.00003\end{array}$ \\
\hline Selenium & $c$ & & 0.005 & 0.020 & $\begin{array}{l}\text { Compliance questionable. } \\
\text { Detection limit is } 0.05\end{array}$ \\
\hline Benzene & $c$ & & & & \\
\hline Chlorobenzene & $c$ & & & & \\
\hline Chloroform & $c$ & & & & \\
\hline Dichlorobromomethane & $c$ & & & & \\
\hline
\end{tabular}


Table 3.12 (continued)

\begin{tabular}{|c|c|c|c|c|c|}
\hline \multicolumn{3}{|c|}{ Former NPDES permit } & \multicolumn{2}{|c|}{$\begin{array}{l}\text { Water Quality } \\
\text { Standards }\end{array}$} & \multirow{2}{*}{ Comments } \\
\hline Parameter & $\begin{array}{c}\text { Monthly } \\
\text { avg. }\end{array}$ & $\begin{array}{l}\text { Daily } \\
\max .\end{array}$ & Continuous & Max. & \\
\hline Methylene chloride & $c$ & & & & \\
\hline Tetrachloroethylene & $c$ & & & & \\
\hline Trichloroethylene & $c$ & & & & \\
\hline 1,1-Dichloroethane & $c$ & & & & \\
\hline $\mathrm{pH}$, standard units & $\begin{array}{c}6.0 \text { to } \\
9.0\end{array}$ & $\begin{array}{c}6.5 \text { to } \\
8.5\end{array}$ & & & \\
\hline
\end{tabular}

${ }^{a}$ Units are milligrams per liter unless otherwise noted.

${ }^{b}$ Water Quality Standards also include limits on organic pesticides, herbicides, and polychlorinated biphenyls not normally detected in Nonradiological Wastewater Treatment Plant effluent.

${ }^{c}$ Monitor only.

${ }^{d}$ Five-day biochemical oxygen demand.

at the source and minimize the generation of waste through process improvements. The NPDES permit expired in April 1991 and is being renegotiated. Facility upgrades may be required to meet new discharge limits. Discharges of nitrates to the watershed have been virtually eliminated and have brought ORNL into compliance with NPDES requirements for reduction in nitrate loading.

\section{Facility status}

Improved treatment of process waste for the removal of radioactivity is planned through an upgrade of the PWTP. This upgrade is necessary because of increased stringency of discharge limits for ${ }^{137} \mathrm{Cs}$ and to maintain goals of as low as reasonably achievable (ALARA). Research, development, treatability studies, and implementation are necessary to optimize treatment. Analysis of alternatives has been completed, and capital projects are being implemented both to replace the PWTP and to improve the treatment capacity of the existing PWTP in the interim. In the upgraded treatment process, ${ }^{90} \mathrm{Sr}$ and ${ }^{137} \mathrm{Cs}$ will be removed using an inorganic ion exchange zeolite. Spent zeolite will be disposed of as SLLW. This process will significantly reduce or eliminate both secondary waste streams (i.e., clarifier sludge and LLLW) that are currently being produced. The process is expected to reduce the secondary waste generation rate by $30 \%$.

The following projects are proposed modifications for upgrading the PWS:

ORNL Process Waste Treatment Facility. This proposed FY 1996 LI will ensure installation of a new process water treatment system to replace the PWTP. The new system will add improved capacities for ${ }^{90} \mathrm{Sr}$ and ${ }^{137} \mathrm{Cs}$ removal. Zeolite dewatering equipment will also be provided by the project.

Upgrade Process Waste Treatment System. This was proposed as an FY 1992 reprogrammed LI project that consists of several modifications to correct environmental, safety, and health deficiencies and to upgrade the processing capabilities of the current PWTP. Included in the project are upgraded chemical-unloading stations, temporary zeolite 
columns for cesium removal, modifications to increase the treatment capacity of the PWTP, infrastructure improvements, and other modifications.

Wastewater Piping Replacement. This FY 1988 GPP will ensure installation of a recycle cooling loop in the Materials Testing Laboratory of Building $4500 \mathrm{~S}$ to eliminate the discharge of chlorinated cooling water to WOC. The Detailed Design was completed during FY 1992. Construction activities were initiated during FY 1993.

Outfall 302 Storm Sewer Rehabilitation. This FY 1992 GPP will ensure rehabilitation of the 24-in. storm sewer line around the Equalization Basin to minimize inleakage of contaminated groundwater into the storm sewer line that discharges through outfall 302 into WOC. Detailed Design activities were completed during FY 1993.

NRWTP Access Controls. This project has been approved as an FY 1993 GPP; access control equipment (i.e., fences, gates, and badge readers) will be installed at the NRWTP and the Bethel Valley Collection Tank Facility. Title II Design for this project was completed in September 1993.

Contaminated Sumps Pumping Modifications. This project has been proposed as an FY 1994 GPP; slightly contaminated wastewater will be segregated in the 4500 Area from the noncontaminated wastewater. The proposed modification will reduce treatment of noncontaminated wastewater in the PWTP and slightly contaminated wastewater in the NRWTP.

\subsubsection{Storage facilities}

No facilities for long-term storage of process waste exist at ORNL; however, several ponds have been used in the past for collection prior to treatment. All of the existing ponds at ORNL have been taken out of service but have not been turned over to ERP because they are used as surge capacity for PWTP feed tanks during periods of heavy rainfall. A new collection tank is being installed to remove them from service completely.

\subsubsection{Disposal facilities}

Solid wastes such as clarifier sludges and spent zeolite will be disposed of as SLLW. Sludge treatment by a private contractor is currently under evaluation. Additional treatment requirements will be addressed as WAC for solid waste disposal sites are developed.

\subsubsection{Status of support systems}

ORNL provides employee training commensurate with job responsibility. As is discussed in Subsect. 3.2.2.5, a certification program is currently being developed for LLLW and process waste streams at ORNL. Database management associated with process waste consists of the reporting requirements set forth in the NPDES permit for ORNL. Water and biological monitoring activities at ORNL are defined by the ORNL NPDES permit and by DOE guidelines for environmental monitoring and surveillance around nuclear facilities. In response to DOE guidelines for environmental monitoring, flow and concentration data are collected to determine discharges of nonradiological constituents from ORNL processes. Under the current NPDES permit there are over 150 monitoring stations, and point sources are monitored at their point of discharge into receiving streams. The Biological Monitoring 
Program includes the collection of fish, milk, soil, and grass for investigation of pollutant movement within the food chain. Implementation of the BMP Plan is also required by the NPDES permit. Continued support of the BMP Plan will ensure that the PWS will not handle "hazardous" wastes. The BMP Plan establishes requirements for the development of a waste-tracking system that will track waste from the point of release from ORNL. WOCC also provides database management support for process waste at ORNL. A discussion of WOCC is provided in Subsect. 3.2.2.5.

\subsubsection{General plant projects}

A listing of proposed LIs and GPPs for the PWS at ORNL is provided in Table 3.13. This table indicates the project title, TEC, and the respective fiscal year for funding.

Table 3.13. Line item and general plant projects for the Process Waste System at Oak Ridge National Laboratory

\begin{tabular}{|c|c|c|}
\hline Title & $\begin{array}{c}\mathrm{TEC}^{a} \\
(\$ \times 1,000)\end{array}$ & $\begin{array}{l}\text { Fiscal } \\
\text { year }\end{array}$ \\
\hline \multicolumn{3}{|c|}{ Line item projects } \\
\hline ORNL Process Waste Treatment Facility & 22,000 & 1996 \\
\hline Process Waste Treatment System Upgrade & 6,000 & 1992 \\
\hline \multicolumn{3}{|c|}{ General plant projects } \\
\hline Wastewater Piping Replacement & 700 & 1988 \\
\hline Chlorine Treatment for Cooling Water & 700 & 1991 \\
\hline Outfall 302 Storm Rehabilitation & 1,065 & 1992 \\
\hline $\begin{array}{l}\text { Nonradiological Wastewater Treatment Plant } \\
\text { Access Controls }\end{array}$ & 396 & 1993 \\
\hline Contaminated Sumps Pumping Modifications & 1,000 & 1993 \\
\hline Outfall Dechlorination $6000 / 4508$ & 501 & 1993 \\
\hline
\end{tabular}

${ }^{a}$ Total estimated cost.

\subsection{GASEOUS WASTE}

Characterization and treatment of air emissions containing radionuclides are of primary importance because most of the major facilities at ORNL are either being used or have been used in the past for work related to nuclear energy. The three general types of radioactive air streams at ORNL include (1) cell ventilation, (2) process off-gas, and (3) laboratory hood and individual vents.

\subsubsection{Strategy}

ORNL policy dictates that airborne effluents should be decontaminated (where practical) at the source of generation before entering one of the plant ventilation systems. 
Effluents with a potential for having relatively high concentrations of radionuclides or reactive chemicals go to process off-gas streams that receive special treatment. The current approach for control of radioactive emissions from ORNL facilities is illustrated in Fig. 3.25.

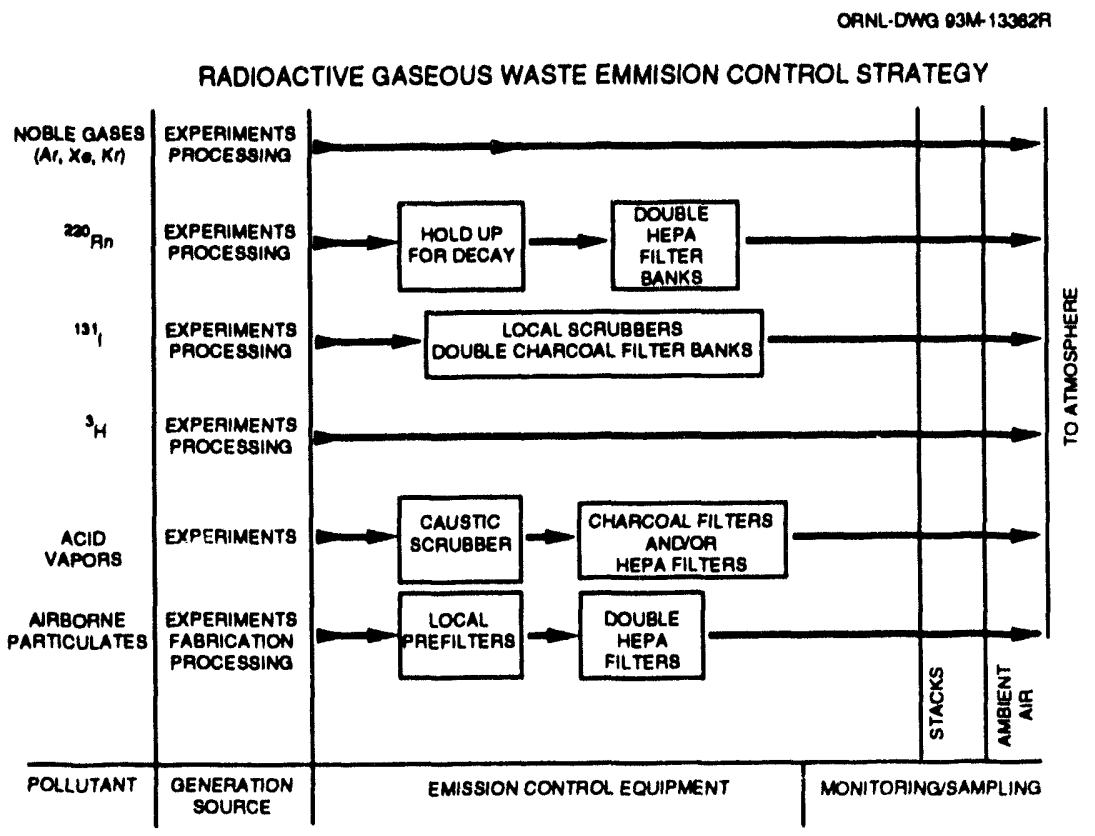

Fig. 3.25. Radioactive gaseous waste emission control. HEPA-high-efficiency particulate air (filter).

The program strategy is to identify and to implement system upgrades needed to ensure continued regulatory compliance and to meet DOE objectives for keeping emissions ALARA. In addition, potential regulatory changes and new regulations are evaluated to determine if additional upgrades or new equipment will be required for future compliance. This strategy is outlined in the draft Strategic Plan for ORNL Waste Management. Technical studies that have been completed or are planned for the future include:

- stack-and-vent surveys to identify potential air emission sources;

- inspection and evaluation of the ventilation ducts, filter houses, emergency power systems, and other pollution control equipment associated with radioactive emission sources;

- preparation of engineering assessments and cost estimates for repair of equipment, such as underground ventilation ducts and filter pits, and the installation of new pollution control equipment;

- determination of flow distribution, particle size distribution, and flow stability and evaluation of the use of new flow instruments in the main ventilation stacks for use in stack sampling and monitoring;

- determination of methods to further reduce emissions as ALARA and in a cost-effective manner; and

- evaluation of new programs and changes in existing programs to ensure continued compliance with regulations. 


\subsubsection{Generic Description and Characteristics of Waste}

The three general types of radioactive air streams at ORNL (Fig. 3.26) include (1) process off-gas streams characterized as low-volume, potentially high-activity gas streams from process vessels and from systems or other sensitive areas where the release of radioactivity may be routine and of relatively high concentration; (2) cell ventilation air streams characterized as high-volume, low-activity gas streams from enclosed areas such as containment or confinement areas, limited-access areas, and hot cells; and (3) laboratory hoods and individual vents that provide controlled ventilation for laboratory-type operations or exhaust from vessels that are vented through appropriate pollution control devices at the source location.

ORNL.DWG $91 \mathrm{M} \cdot 13364 \mathrm{R}$

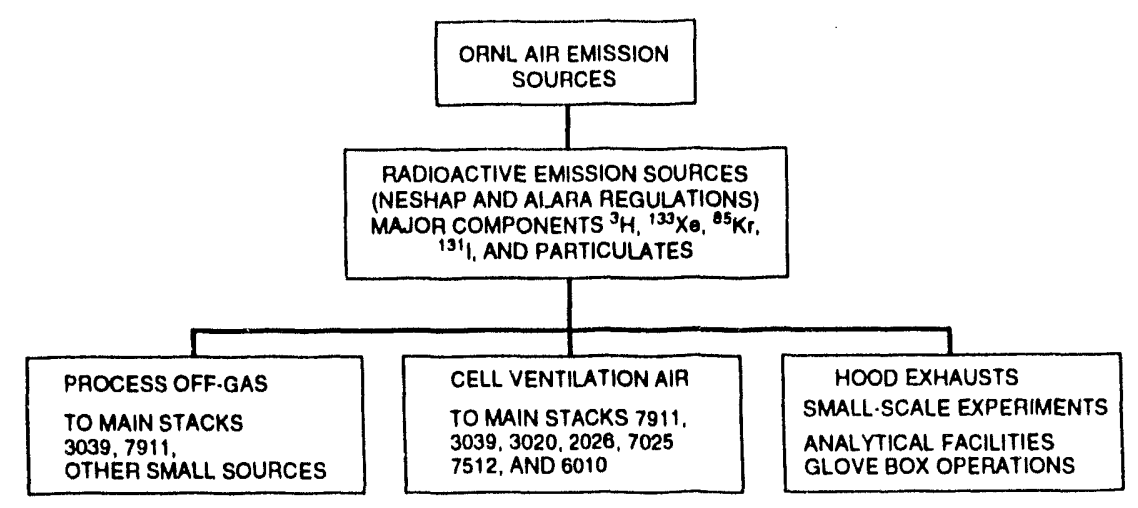

Fig. 3.26. Emission sources at Oak Ridge National Laboratory. NESHAP-National Emission Standards for Hazardous Air Pollutants, ALARA-as low as reasonably achievable (DOE Order 5480.11).

\subsubsection{Treatment Facilities}

Essentially all radioactive air streams (including cell ventilation air, process off-gas, and air from hoods and individual sources) are filtered through roughing and HEPA filters to remove particulates before being discharged. Where conditions dictate (particularly for the off-gas emissions), charcoal absorbers or chemical scrubbers are used to remove reactive gases such as halogens and acidic vapors. For short half-life radionuclides, such as radon, holdup is used to allow decay before discharge. Noble gases are diluted with cell ventilation air and discharged to the stacks. Because of the small quantities involved, collection and storage of these gases is not considered practical. The procedures and equipment used in the tritium-handling facilities are designed to minimize the release of tritium.

The basic equipment used in most of the cell ventilation systems that discharge to major stacks includes filters, fans, and the ducts used to transport air. Typically, the filters are located in concrete pits that are below-grade level with the top surface exposed. The top of most filter pits is covered with removable concrete slabs that are sealed with an asphalt compound. Air flow is normally provided by electrically driven fans. Upon loss of negative pressure in the ducts, standby fans operated by steam or standby electrical power start automatically to provide ventilation air. Radiation-monitoring instruments are connected to either the stacks or ducts entering the stacks.

Seven stacks are currently used for discharging cell ventilation air and process offgas containing gaseous radioactive effluents. A major emphasis is placed on the use of 
negative pressure and a positive flow of air through containment areas to the stacks for the control of radioactive air emissions. The 3039, 3020, and 2026 stacks are located in the main ORNL area. The 6010 stack is located at the east end of the ORNL area, and the 7025 stack is located east of the 7000 Shop Area. The 7911 and 7512 stacks are located in Melton Valley. The location of the stacks is shown in Fig. 3.27. The 7830, 7877, and 7860 stacks (also shown in Fig. 3.27) serve the Melton Valley Waste Storage Tank Facility, the LowLevel Waste Solidification Facility, and the NHF (shut down). Each of the major cell ventilation treatment systems is described in the following paragraphs.

The 3039 stack handles the cell ventilation and process off-gas from most of the facilities in Bethel Valley. The system is illustrated in detail in Fig. 3.28. The stack is connected with the ventilation systems in major areas $(4500,3500,3025,3026$, Isotopes, Solid State, and the ORR) by large underground concrete ducts, by underground transite ducts, and by aboveground steel ducts. Except for the 3025 and 3026 Areas, the gas stream from each area passes through HEPA filters before going to the 3039 stack. Cell exhaust air from Buildings 3025 and 3026 (east) passes through HEPA filters within the building. Cell exhaust from Building 3026 (west) is not filtered.

The 7911 stack system handles the ventilation air and process off-gas from HFIR (7900) and the REDC (Buildings 7920 and 7930) in Melton Valley (Fig. 3.29). The HFIR cell ventilation air goes through 76.2-cm-diam (30-in.) underground transite ducts to the filter pit located at the base of the 7911 stack. HFIR ventilation air is filtered through silvercoated copper mesh, charcoal, and HEPA filters in series before going through fans and a 122-cm-diam (48-in.) steel duct (located aboveground) to the stack. The cell ventilation air from Building 7920 passes through HEPA filters located in a filter pit adjacent to the building and then goes through a 76.2-cm-diam (30-in.) underground steel pipe (coated on the exterior with an asphalt compound) to fans located at the 7911 stack. Downstream from the fans, the ventilation air from Buildings 7920 and 7930 joins together in a 122-cm-diam (48-in.) steel duct (located aboveground) that goes to the 7911 stack.

The 3020 stack provides cell ventilation for the Radiochemical Processing Pilot Plant in Building 3019 (Fig. 3.30). Ventilation air from this facility goes through aboveground stainless steel ducts to single sets of HEPA filters located in two filter pits at the base of the 3020 stack.

The 2026 stack provides cell ventilation air for the HRLAL. Cell ventilation air from this facility passes through HEPA and charcoal filters located in a filter pit at the base of the stack before being discharged (Fig. 3.31).

The 7512 stack provides a flow of air through the Molten Salt Reactor Experiment building. Ventilation is maintained even though the reactor is no longer in operation.

Aboveground steel ducts are used to convey ventilation air from the building to the HEPA filters and stack (Fig. 3.32).

The 6010 stack serves the Oak Ridge Electron Linear Accelerator. Ventilation air from the target room and the 40-m (130-ft) flight station passes through HEPA filters before being discharged to the stack (Fig. 3.33).

The 7025 stack serves a Tritium Target Fabrication Facility, which is no longer in operation. Since HEPA filters are not effective for tritium ventilation, air from this facility goes directly to the stack (Fig. 3.34).

An eighth stack, 3018 , is no longer in service, although it is used to discharge air from a small fan that maintains a small flow of air through the ORNL Graphite Reactor. The reactor was shut down in 1963.

Process off-gas air emissions are treated by a Central Process Off-Gas System that vents to the 3039 stack. This system serves the Bethel Valley area facilities. A network of underground stainless steel pipes transports the off-gas from facilities throughout the area. 
ORNL-DWG 88M-7048R5

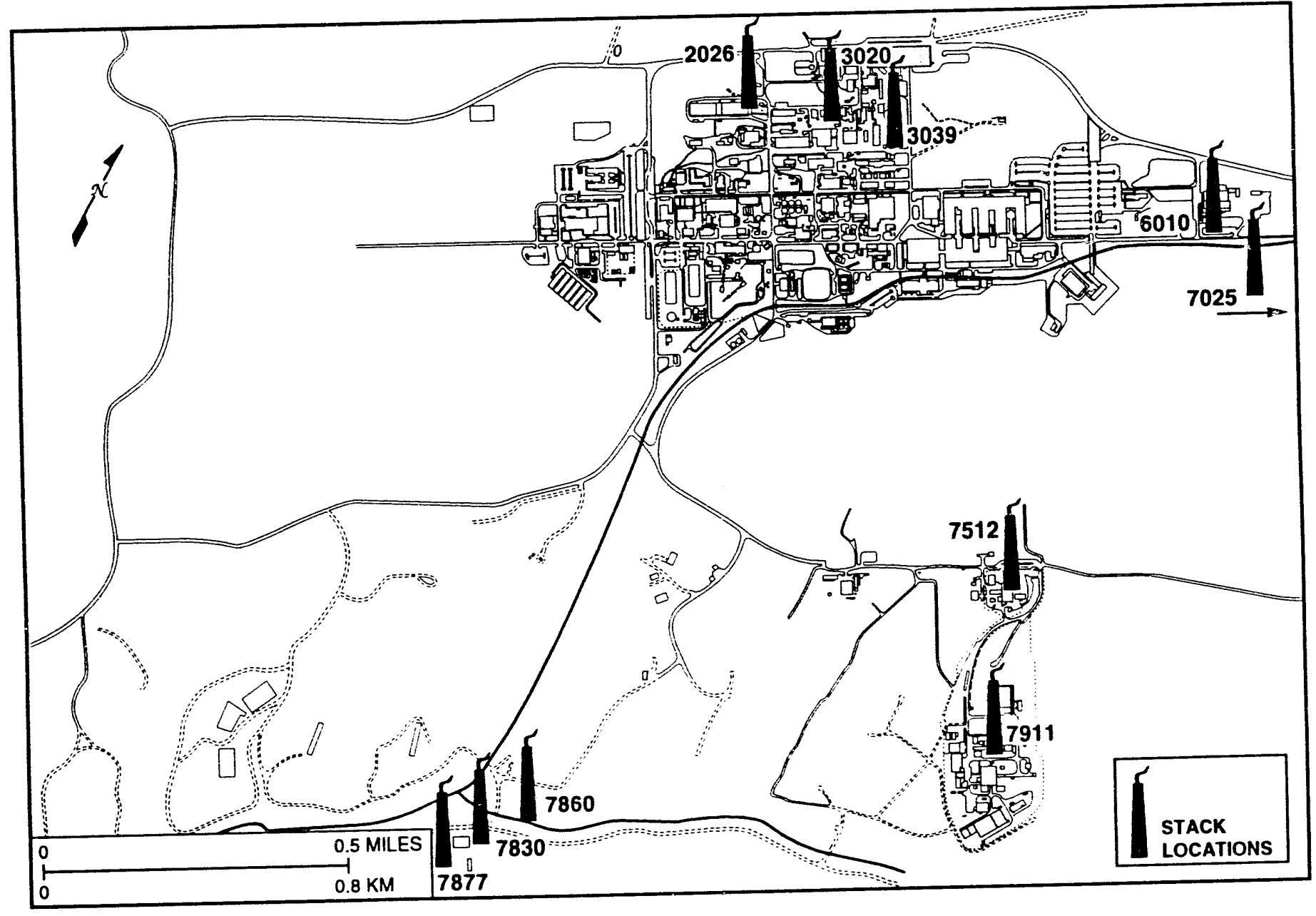

Fig. 3.27. Location of major cell ventilation stacks at Oak Ridge National Laboratory. 


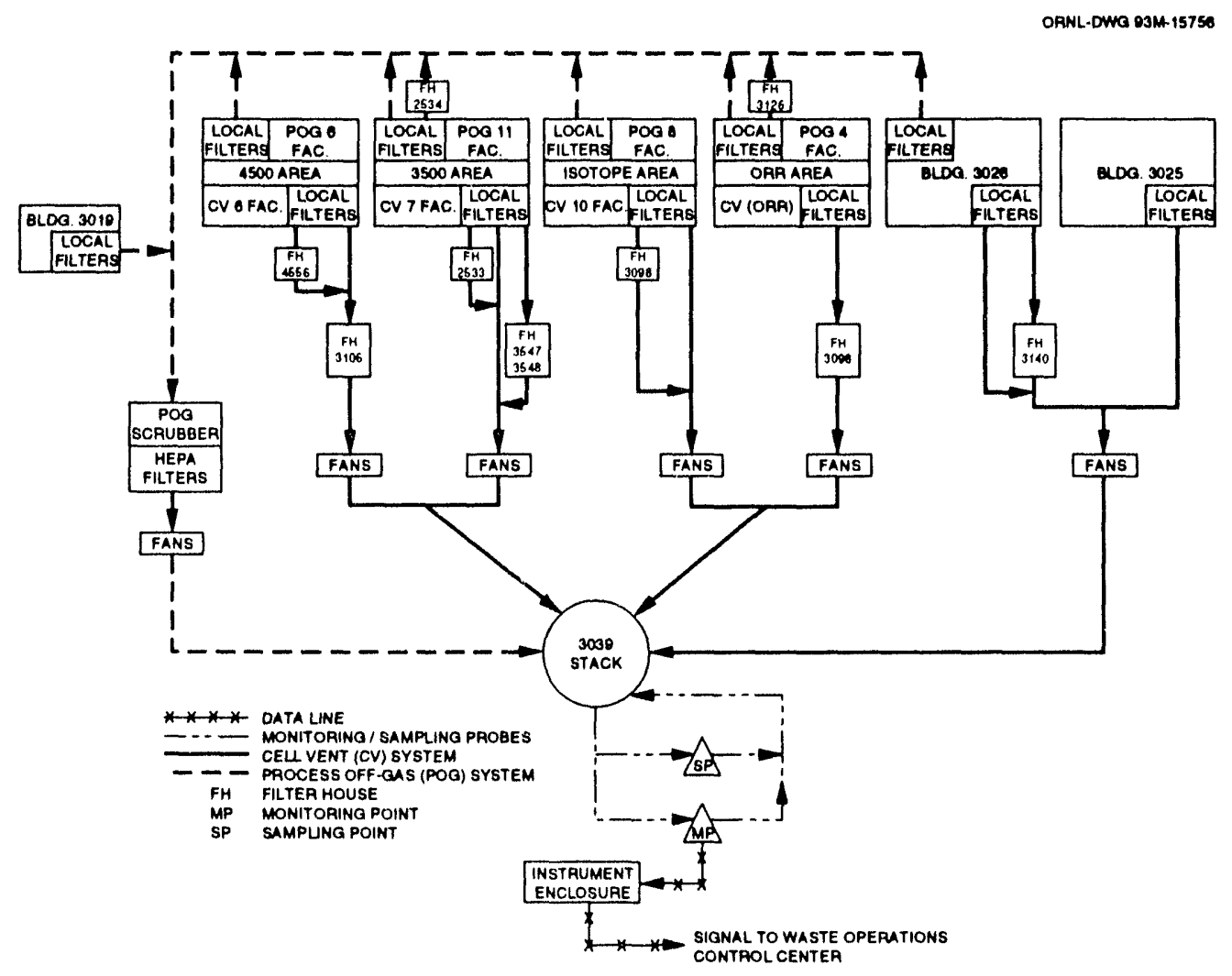

Fig. 3.28. Oak Ridge National Laboratory's Central Ventilation System for Bethel Valley facilities (3039 stack).

Because the process off-gas can contain acidic vapors that could damage HEPA filters, the off-gas is passed through a venturi caustic scrubber before going through roughing and HEPA filters to fans that discharge to the 3039 stack.

Process off-gas from facilities in Melton Valley discharges to the 7911 stack. The HFIR and REDC Facilities have separate process off-gas systems. Hot off-gas from HFIR is filtered through silver-copper, charcoal, and HEPA filters before being discharged upstream of the cell ventilation filters. In one part of the REDC (Building 7920), process off-gas discharges through a caustic scrubber and HEPA filters to the stack. A Hopcalite-charcoal iodine retention system and a backup charcoal absorber bed are valved into the off-gas system when irradiated material containing significant amounts of ${ }^{131} \mathrm{I}$ is being processed. After passing through the filters, the off-gas goes through an underground 25.4-cm-diam (10-in.) fiberglass-reinforced pipe to fans at the 7911 stack. Off-gas from the other REDC Facility (Building 7930) passes through HEPA filters and is combined with the ventilation air upstream of the cell ventilation filters before being discharged to the 7911 stack.

Provisions for adding a caustic scrubber are available if needed. The process off-gas systems described above are the major systems at ORNL through which most of the process off-gas is discharged and are typical of other smaller systems.

In addition to these stacks, a number of individual vents are used at ORNL through which small quantities of radioactive material may be discharged. Located throughout the ORNL facilities, these sources are mainly vents from storage tanks and exhausts from hoods and glove boxes used for individual small-scale experiments and analytical chemistry work; 


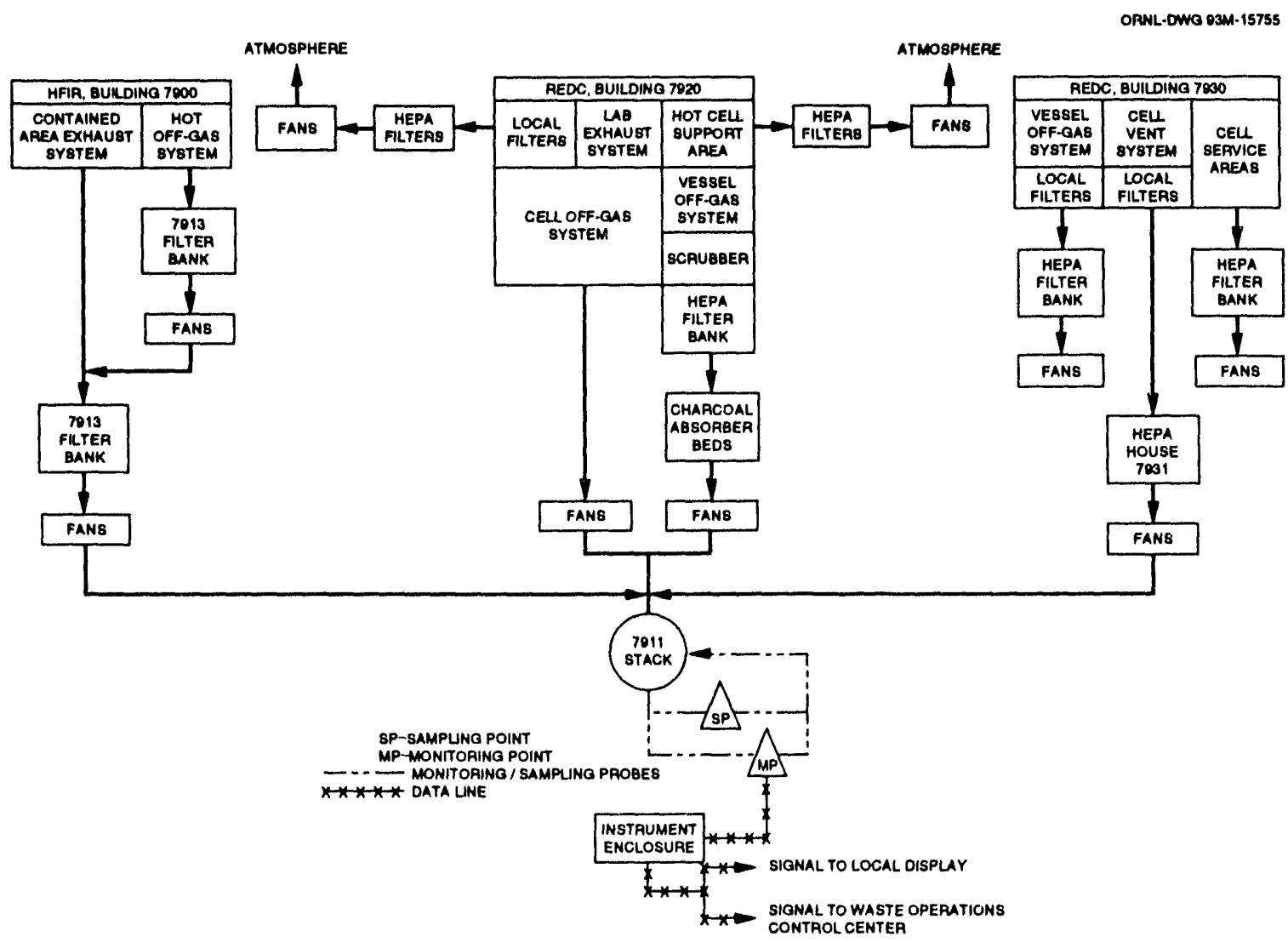

Fig. 3.29. Oak Ridge National Laboratory's Central Ventilation System for Melton Valley facilities (7911 stack). HFIR - High Flux Isotope Reactor; REDC-Radiochemical Engineering Development Center; HEPA-high-efficiency particulate air filter.

however, larger facilities such as the Transuranium Research Laboratory in Building 5505, the Isotope Technology Building (3047), the Electron Linear Accelerator Facility in Building 6010 , and the NHF in Building 7860 also have vents.

Buildings such as the 4500 Area have many laboratories that have hoods with individual exhausts. The individual exhausts have been identified and placed in a computer database as a result of the recent stack-and-vent survey. This data will be used to identify emission sources for possible equipment upgrade. Individual emission sources are typically discharged through HEPA filters, fans, and short stacks located above roof level. Emissions from most of the systems are limited by administrative controls and do not require radiation monitors in the exhaust streams.

\subsubsection{Environmental sampling and monitoring}

Most gaseous wastes from ORNL are released to the atmosphere through stacks. Radioactivity may be present in gaseous waste streams as a solid (i.e., particulates), as an absorbable gas (e.g., iodine), or as a nonabsorbable species (i.e., noble gas). Gaseous wastes that may contain radioactivity are processed to reduce the radioactivity to acceptable levels before they are discharged. The discharge stacks are sampled and monitored prior to their release to the environment. The ES\&H Protection Division is responsible for maintenance 
ORNL-DWG $93 M+15754$

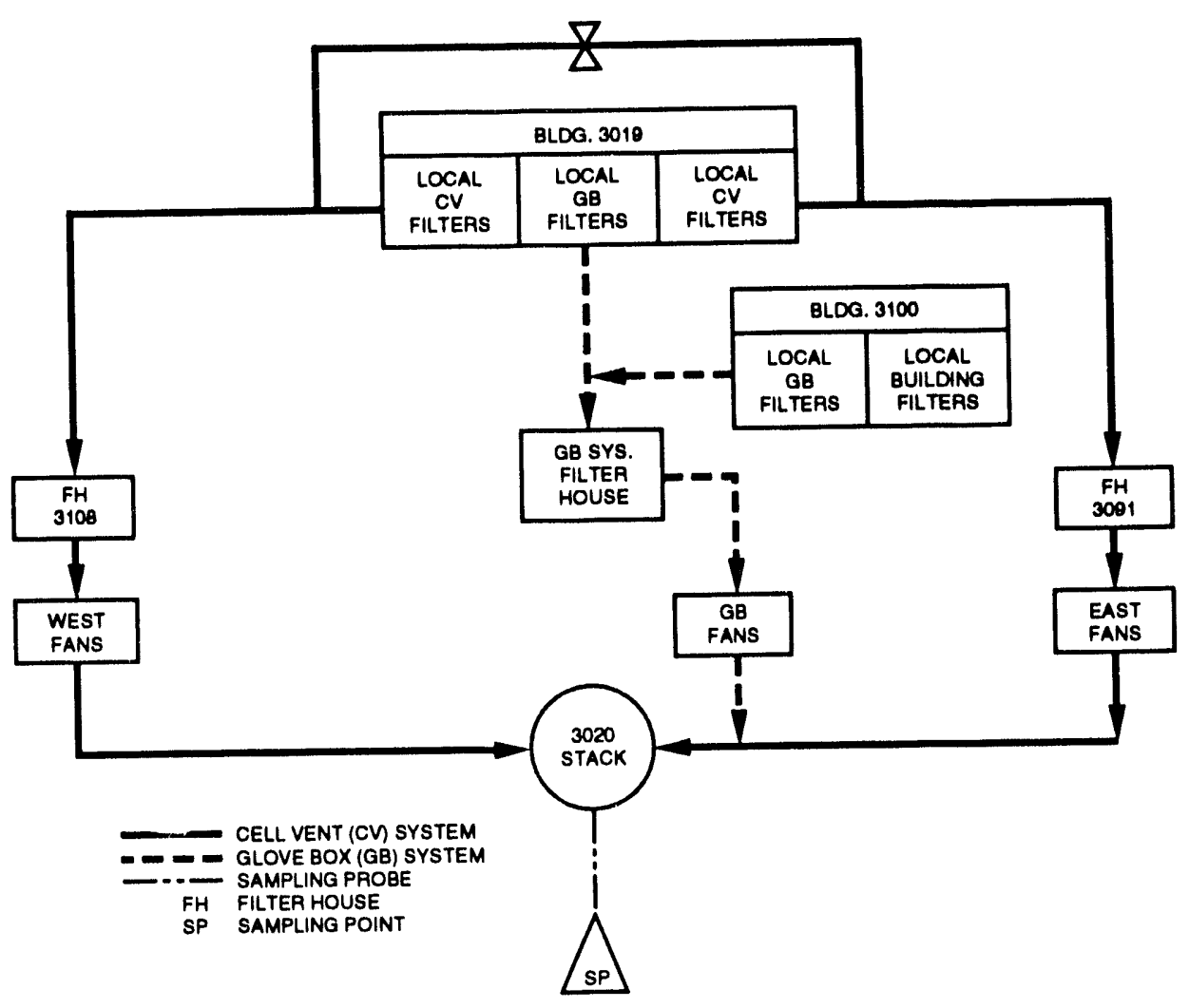

Fig. 3.30. Ventilation System for the Radiochemical Processing Pilot Plant (3020 stack).

and operation of ORNL gaseous waste sampling systems. The responsibility for monitoring system maintenance and operation is the responsibility of the waste generator.

The sources of radiological gases emitted from ORNL facilities are regulated into two categories: major and minor sources. Four stacks at ORNL are considered major sources: $3039,7911,3020$, and 2026. Each of these has both sampling and monitoring performed continuously. Samples are collected weekly while the various stack monitoring systems send their signals to WMRAD's WOCC.

Changes in National Emission Standards for Hazardous Air Pollutants (NESHAP) regulations for quantifying radiological releases from major sources has placed increased emphasis on sampling. The regulations require continuous emissions sampling, using methods that comply with ANSI N13.1 (1969, R-1982) standards, for any emission point with the potential to cause an annual public dose exceeding 0.1 mrem. An upgrade program was initiated to modify each source to meet compliance criteria, the focus of which was the correction of deficiencies in the sampling layout and/or instrumentation as required to satisfy these changes. Completed in the fall of CY 1992, the upgraded program fulfilled the commitments in the FFCA between DOE and the EPA, Region IV.

\section{Major sources}

3039 stack. The sampling system consists of a five-nozzle sample probe, a sample transport line, a filter, two charcoal canisters, a catalytic converter, a silica gel cartridge, two 
ORNL.DWG $93 M \cdot 15752$

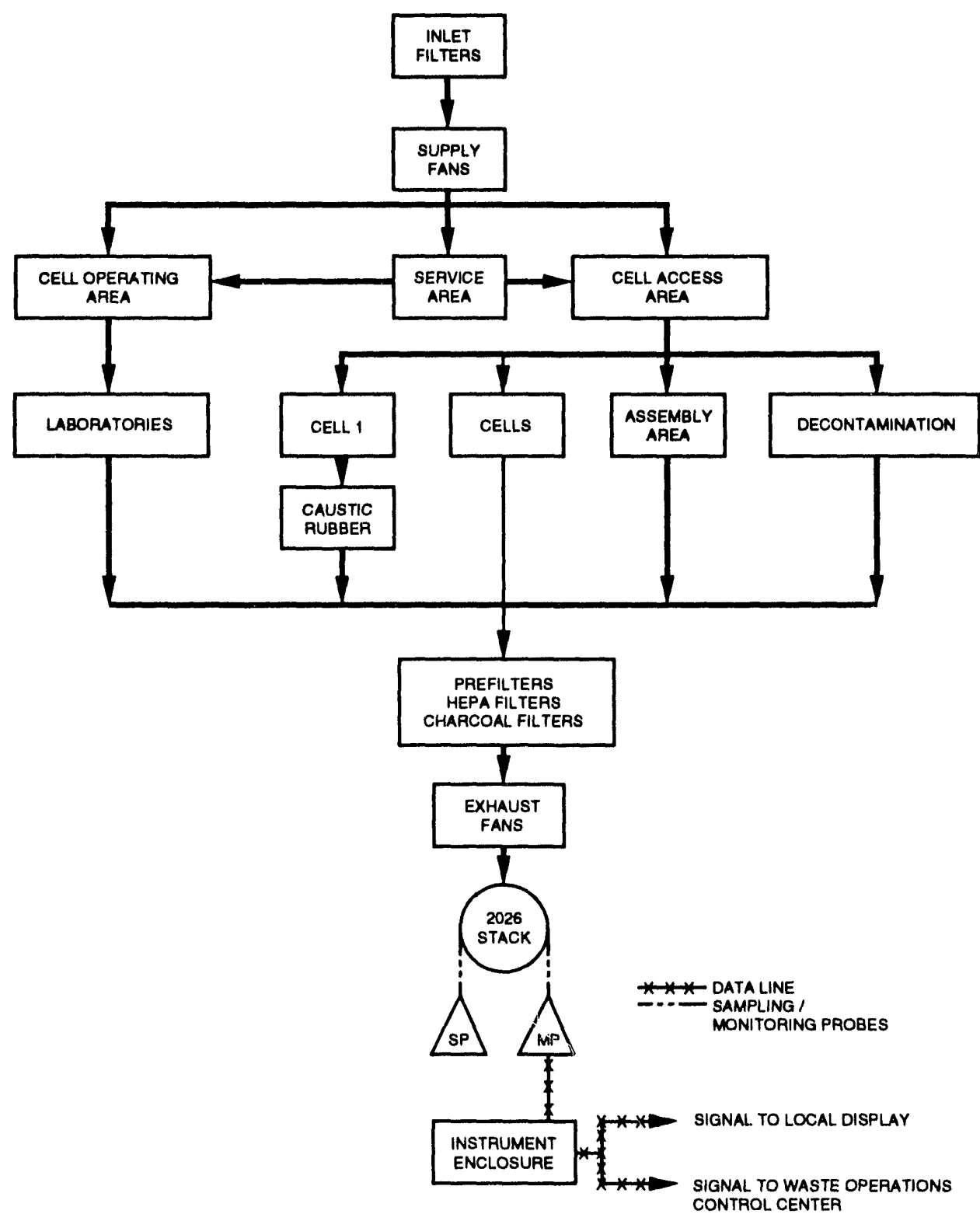

Fig. 3.31. Ventilation System for the High-Radiation-Level Analytical Laboratory (2026 stack).

mass flow controllers, and two pumps. All of this equipment is located on the platform $15 \mathrm{~m}$ $(50 \mathrm{ft})$ above the base of the stack. This location was chosen to minimize deposition within the probe located in the stack.

The monitoring system utilizes three probes to pull a portion of the gas stream through several monitoring devices. One probe serves the gross alpha particulate and the radioiodine monitor. This probe extracts a continuous flow of air through a filter paper tape deck and then to a charcoal trap before being drawn through the sample pump and exhausted back into the stack. The alpha particulate monitor consists of a scintillation counter that uses zinc sulfide as the scintillator. The charcoal trap is monitored by one to 
ORNL.DWG $93 M-16761$

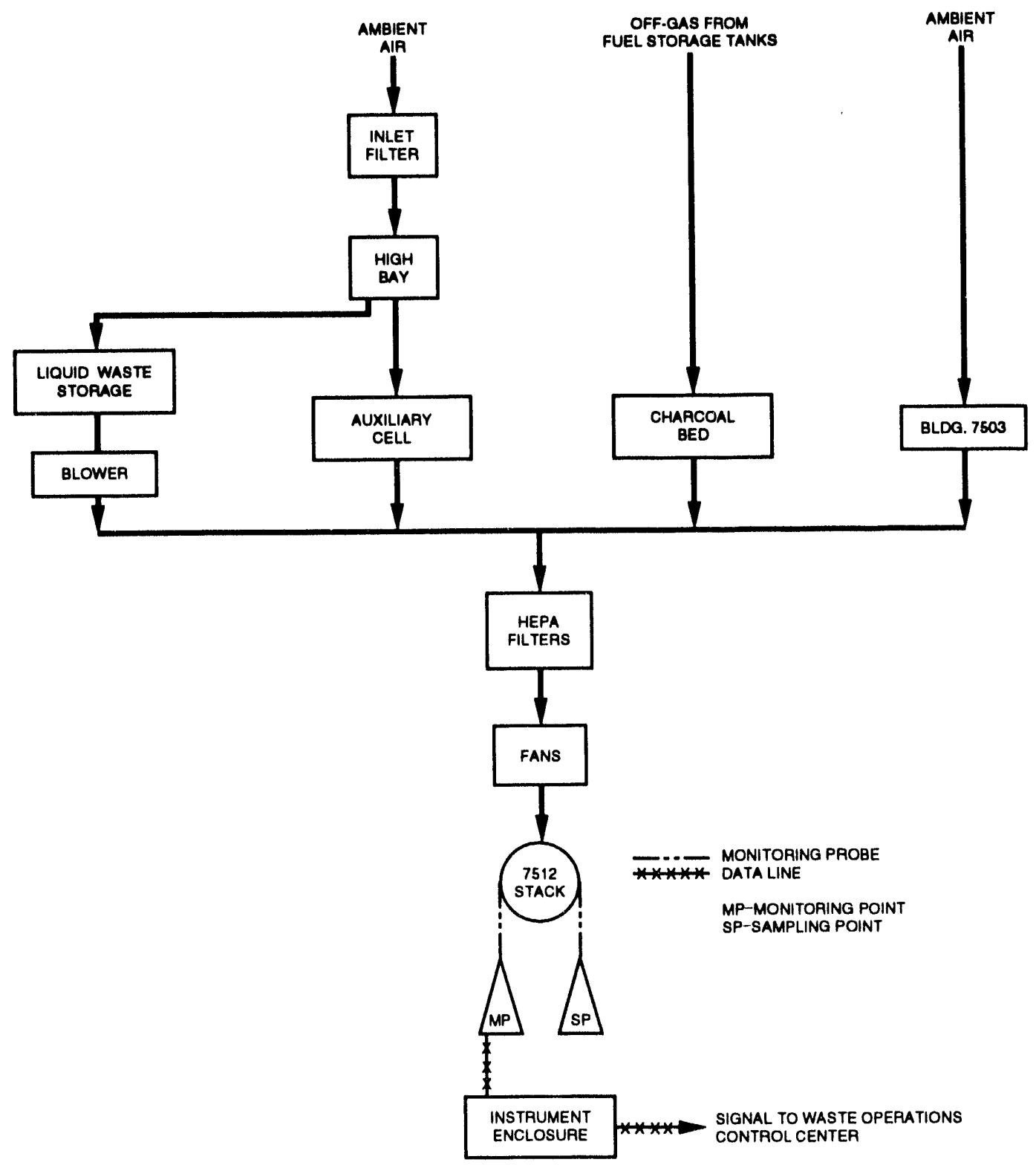

Fig. 3.32. Ventilation System for Molten Salt Reactor Experiment (7512 stack).

four Geiger-Mueller (G-M) tubes connected in parallel. The second probe is used to monitor for beta-gamma particulate and is connected, first, to a filter paper tape deck (similar to the alpha monitoring system), and then, to a count rate meter and a G-M tube. The third probe draws effluent via a probe located $1.6 \mathrm{~m}(5 \mathrm{ft})$ above grade level to a noble gas monitor. The noble gas monitor is an end-window-type G-M tube and is connected to a count rate meter. The count rate meter analogous to those used for alpha and beta-gamma particulate provides a signal output indicating the integrated counts from the detector. The signal from the count rate meters is sent to the WOCC via data concentrators located near the stack. 


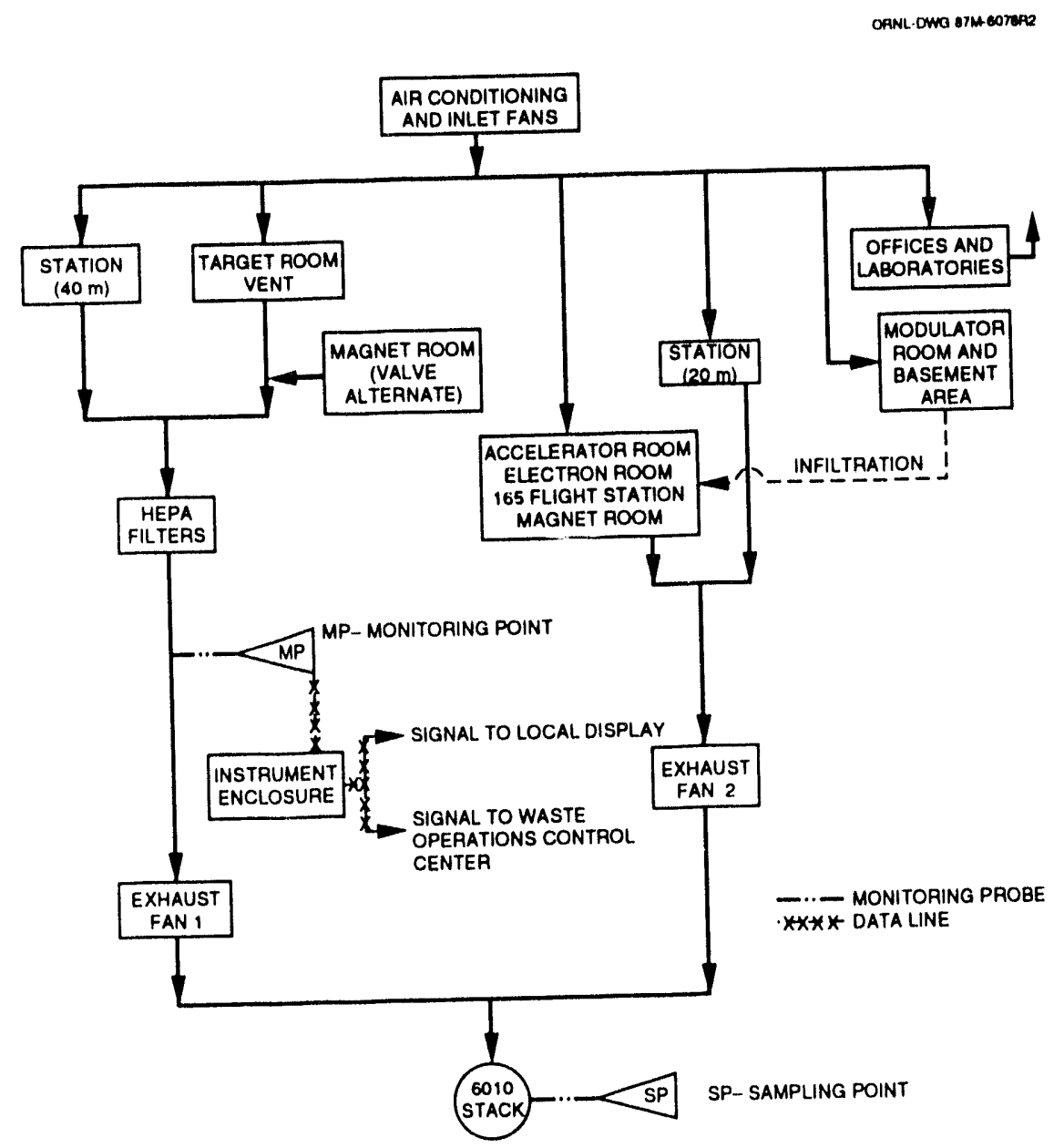

Fig. 3.33. Ventilation System for Oak Ridge Electron Linear Accelerator (Building 6010).

In addition to sampling and monitoring at the $15.2-\mathrm{m}(50-\mathrm{ft})$ level, duct beta-gamma monitors are used from the cell ventilation at the 3500 Area, the off-gas from the 3500 Area, and the outlet to the off-gas caustic scrubber. The signals from these monitors are also sent to WOCC.

7911 stack. The sampling system consists of a five-nozzle sample probe, a sample transport line, a filter, two charcoal canisters, a catalytic converter, a silica gel cartridge, two mass flow controllers, and two pumps. All of this equipment is located on the platform $15.2 \mathrm{~m}(50 \mathrm{ft})$ above the base of the stack. This location was chosen to minimize deposition within the probe located in the stack.

The monitoring equipment for this stack is located at the $15.2-\mathrm{m}(50-\mathrm{ft})$ level similar to 3039 . The particulate alpha and beta detectors monitor levels on a filter paper that is advanced once per day. The particulate detectors are needed to detect the presence of transuranium and fission product isotopes. Two different scintillation phosphors, zinc sulfide and a plastic phosphor for the alpha and beta detectors, respectively, are coupled together in the same assembly with the necessary shielding. A sodium iodide detector is used to differentiate ${ }^{131} \mathrm{I}$ from other possible gamma emitters. This detector is placed in close proximity to a silver zeolite cartridge to monitor its continuous collection. The system is designed so that cartridge replacement is required no more than once per week. Using a beta 
OANL.DWG 93M 16763

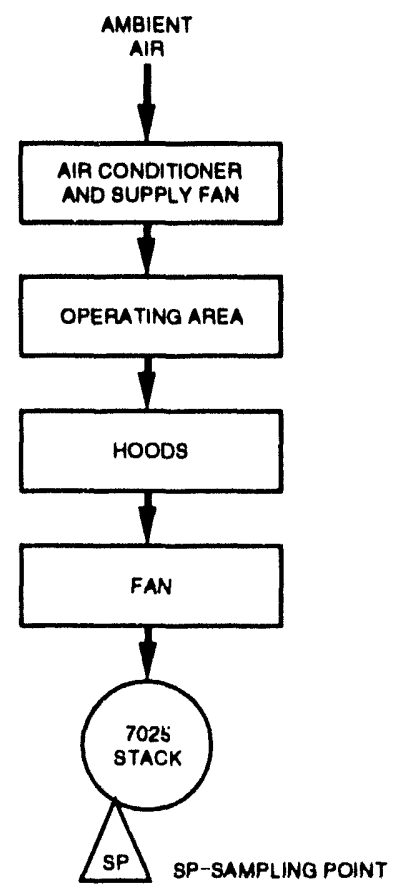

Fig. 3.34. Ventilation System for Tritium Target Fabrication Facility (Building 7025).

scintillation detector, noble gases are also monitored downstream of the iodine detector. The noble gases, principally krypton and xenon, are passed through a fixed volume that is continuously monitored for activity. The last detector, a tritium monitor, is a separate device that analyzes a slipstream of the gas as it passes through the serial detectors of alpha, beta, iodine, and noble gases.

Duct monitors are also located on each of the three input ducts to the 7911 stack. These monitors are used to identify which of the facilities that vent through the 7911 stack may be responsible for the release of radiological material. This knowledge, coupled with information about the operating activity of each facility, can potentially identify the radioisotope(s) released during an unusual occurrence. All monitoring signals are sent to WOCC. However, response due to normal equipment operation, maintenance, and malfunction belongs to the owners of the facilities discharging this stack.

3020 stack. The sampling system consists of a six-nozzle sample probe, a sample transport line, a filter, two charcoal canisters, a catalytic converter, a silica gel cartridge, one mass flow controller, and one pump. All of this equipment is located on the flatform $15.2 \mathrm{~m}$ $(50 \mathrm{ft})$ above the base of the stack. This location was chosen to minimize deposition within the probe located in the stack.

At present, the monitoring systems at the stack are being removed in favor of the more accurate and regulatory required sampling system. The use of duct monitors for flow and gross trend and alarm capabilities will continue to be used by the operating facilities. 
2026 stack. The sampling system consists of a five-nozzle sample probe, a sample transport line, a filter, two charcoal canisters, a catalytic converter, a silica gel cartridge, two mass flow controllers, and two pumps. All of this equipment is located on the platform

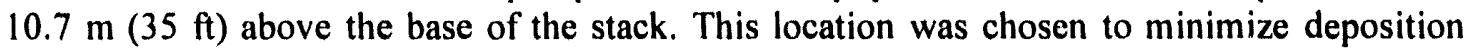
within the probe located in the stack.

\section{Minor sources}

In addition to the major sources, ORNL has 13 point sources and 2 different grouped sources (laboratory hoods). Minor sources emit radionuclides that result in a potential dose lower than $0.1 \mathrm{mrem} /$ year to the most exposed member of the public. These sources were sampled individually during 1992 in accordance with the NESHAP Compliance Plan for the ORR. Emissions from the grouped sources were estimated using radionuclide inventory data and emission factors provided in 40 CFR Pt. 61, Appendix D. Laboratory hood emissions typically result from bench-scale experiments and are exhausted through small stacks or vents. All minor sources will be evaluated on a 1- to 3-year basis depending on the type of radionuclide emission. Table 3.14 contains a list of all of the minor sources.

Table 3.14. Minor sources of radiological gases emitted from Oak Ridge National Laboratory facilities

\begin{tabular}{ll}
\hline \multicolumn{1}{c}{ Minor or grouped source } & \multicolumn{1}{c}{ Facility name } \\
\hline X-2000 & Building 2000 (contains old uranium and thorium furnaces) \\
X-3018 & Oak Ridge Graphite Reactor \\
X-3074 & Manipulator Repair Shop (two emission points) \\
X-3544 & Process Wasie Treatment Plant \\
X-5505 & Transuranium Laboratory (three emission points) \\
X-7025 & Tritium Target Fabrication Facility \\
X-7512 & Molten Salt Reactor Experiment \\
X-7567 & LLW tank vault with forced air fan \\
X-7830 & LLW tanks and vaults at New Hydrofracture Facility (four emission \\
X-7852 & points) \\
X-7860 & Old Hydrofracture Facility (two emission points) \\
X-7877 & New Hydrofracture Facility (three emission points) \\
X-Laboratory hoods & LLLW Solidification Facility or Emergency Avoidance Solidification \\
Decommissioned lab hoods & 24 hoods total \\
X-miscellaneous rooms & Lampaign areas \\
\hline
\end{tabular}

"Low-level waste. 


\section{Ambient sampling}

Significant changes have been made to the Ambient Air-Monitoring Program for the ORR. The changes were based on the environmental monitoring requirements set forth in DOE Orders 5400.1, 5400.5, and the DOE's Environmental Regulatory Guide for Radiological Effluent Monitoring and Environmental Surveillance. The current Ambient AirMonitoring Program has a principal objective of surveillance utilizing sampling systems instead of real-time monitoring. Eight perimeter air-monitoring stations and two remote airmonitoring stations are used for the ORR.

The sampling system used is a modified high-volume air sampler for collection of particulate uranium. The sampler is operated for 7-day collection periods and equipped with a mass-flow controller and a flow totalizer. A separate sampler is used for the collection of tritiated water. This sampler consists of a prefilter followed by indicating silica gel for the capture of tritiated water. A mass-flow controller and flow totalizer will be used to maintain a constant flow rate and to indicate the total volume of air sampled.

Atmospheric dispersion modeling was used to select appropriate sampler locations. The Industrial Source Complex Code was selected for this study. The code is EPA-approved for determining downwind concentrations from individual sources at multiple receptor sites (i.e., sampler locations). The highest concentrations from ORR affecting residences, businesses, or parks were determined by evaluating the model results. Combined impacts from all sites were determined, and sites were ranked.

The Ambient Air-Monitoring Program at ORNL consists of four perimeter airmonitoring sites located around the site boundary (Fig. 3.35). A high-volume particulate sampler, tritium silica gel sorbent train, and charcoal filter sampler are collocated at each of the four sites. These sites were determined by intersecting the major wind directions at ORNL and providing sampling coverage for Bethel and Melton Valleys. The operation and sample collection from the ORNL stations is consistent with the ORR stations.

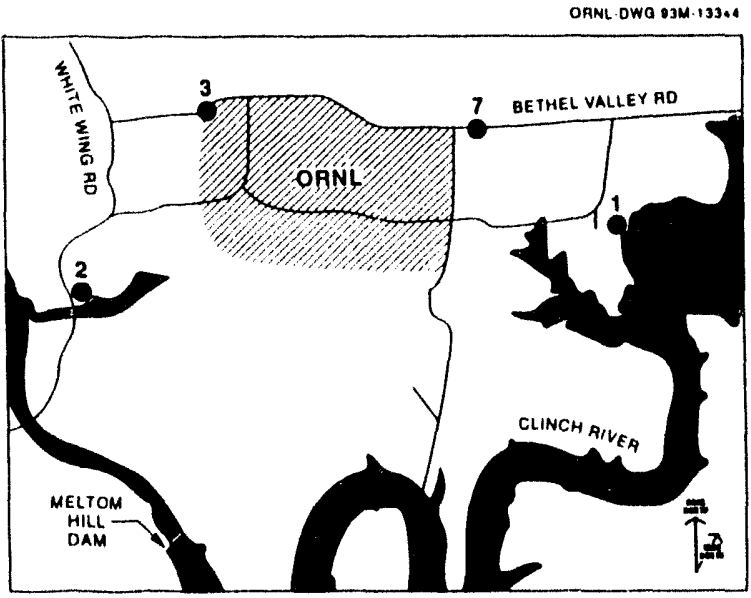

Fig. 3.35. Ambient air-monitoring locations at Oak Ridge National Laboratory.

The sampling equipment at or near these calculated points of maximum impact are on locations under the control of the ORR. No residences or businesses are predicted to be routinely affected by significant concentrations of radioactive material released from ORR without such releases being sampled at one of these selected locations. In addition to the eight stations listed above, two others are used at remote locations to provide an estimate of 
background radionuclide concentrations: Remote Air Monitor 52 at Fort Loudon Dam and Remote Air Monitor 58 at Norris Dam.

Samples collected from the high-volume sampler will be collected weekly. Composite isotopic analysis of the filters will be conducted at least quarterly. Tritium samples will be collected biweekly and composited every 4 weeks. Particle size determinations will be made on annual basis at select ambient air stations.

\subsubsection{Permitting status}

Control of airborne emissions from ORNL facilities is provided in accordance with DOE Orders 5480.1 A, 5480.4, 5480.11, 5820.2A, and the Clean Air Act (CAA). The requirements of the CAA are being administered through the TDEC Air Pollution Control Regulations. Air permits have been obtained for all emission sources that require permitting under TDEC regulations.

The CAA authorizes the establishment of NESHAP regulations for pollutants for which Ambient Air Quality Standards are not applicable. Radionuclide emissions are regulated under the NESHAP regulations by the EPA. The state has been authorized to regulate in this area. Under the NESHAP regulations (40 CFR Pt. 61, Subpart H), emission of radionuclides to the ambient air from DOE facilities is limited to those amounts that would cause any member of the public to receive an effective dose equivalent of $10 \mathrm{mrem} /$ year.

\subsubsection{Facility status}

Many of the facilities for handling radioactive gas emissions have been in operation for over 20 years. Generally, the equipment that is accessible has been maintained in good working condition. A considerable amount of upgrading of equipment by LI and GPP projects has been completed. Backup units exist for some equipment to be used in the event of failure. However, much of the equipment, such as underground ducts and filter pits, has not been evaluated for long-term wear, deterioration, or reliability for continued long-term service. The status of upgrade activities and new facilities for gaseous waste management is described in the following paragraphs.

\section{Upgrade 3039 stack fans}

The Central Radioactive Gas Disposal Facility (3039) is the central stack through which cell ventilation air and process off-gas from the main ORNL Complex are discharged. This project replaces three of the steam turbine drive units that provide power for the backup fans in the event the motor drive fans lose electrical power or otherwise fail. Procurement of the turbines has occurred. Construction is scheduled for completion in FY 1994.

\section{Liquid/Gaseous Waste Support Facility}

This 1992 GPP would construct a support facility for liquid and gaseous waste operations. The facility would consist of hardware and equipment storage as well as equipment maintenance facilities necessary to support operation of the 3039 stack Off-Gas and Cell Ventilation System and other gaseous emission systems, the PWTP, and the NRWTP. 


\section{Waste Operations Control Center expansion}

This 1991 GPP would construct a change house for Waste Management Operations personnel to replace current facilities. Facility design began in FY 1993; construction is scheduled for completion in FY 1994.

\section{Upgrade Hot Off-Gas System at 3039 stack}

The Hot Off-Gas System is a critical portion of the Central Radioactive Gas Disposal Facility (3019). This project will relocate and replace fans, electric motors, backup steam turbine, and appropriate ducting that provide motive force for the Hot Off-Gas System. This project has been proposed as a 1994 GPP.

\section{Upgrade 3039 stack support}

Recent studies have indicated that the 3039 stack could sustain structural damage because of either seismic or high-wind events considered possible for the ORNL site. This project, proposed as a $1995 \mathrm{GPP}$, will provide reinforcement to the existing structure to decrease its vulnerability.

\section{Ventilation System upgrade (3500)}

Inspection and monitoring of the water flow from the underground ventilation ducts from the 3500 Areas to the 3039 stack has shown concrete deterioration and tree root intrusion in some areas. This allows groundwater to be drawn in by the negative pressure in the duct. This project will upgrade the underground concrete cell ventilation duct work to improve the efficiency of the Ventilation System and reduce potentially contaminated water that must be treated at the PWTP. This project has been proposed as a 1995 GPP.

\section{Upgrade 3047 Filter House}

Ventilation air from the manipulator cells in the Isotope Technology Building, Building 3047, goes through in-cell HEPA filters before being discharged to the 3039 stack. Sealing problems with the in-cell HEPA filters has allowed contamination (mainly europium and cobalt) to reach the underground duct and second set of HEPA filters. This project will provide an additional set of underground HEPA filters to stop airborne material from reaching the second set of HEPA filters in sufficient quantities to cause a radiation problem. This project will be proposed as an FY 1995 GPP.

\subsubsection{Storage and Disposal Facilities}

$\Lambda$ ir emissions at ORNL are routinely treated and discharged through sampled and monitored ventilation stacks on-site. Because radioactive air emissions from ORNL facilities are collected, treated, and discharged via these stack systems, no storage or disposal facilities are required. All solid wastes (e.g., HEPA filters) generated in the treatment processes are handled as part of the Solid Radioactive Waste Management Program (see Subsect. 3.1 of this document). 


\subsubsection{Status of Support Systems}

No specific training, certification, or database management system is available at ORNL, for radioactive gaseous emissions. Training is generally commensurate with the employee's job responsibility; certification and database management are associated primarily with solid waste streams. WOCC does provide data regarding air flow rates for gaseous waste effluent streams in stacks and ducts. The alarms for the high-level gamma stack monitors are also telemetered to WOCC.

\subsubsection{General Plant Projects}

A listing of GPPs for gaseous radioactive waste facilities at ORNL is provided in Table 3.15. This table indicates the project title, TEC, and the respective fiscal year for funding.

Table 3.15. General plant projects for gaseous radioactive waste facilities at Oak Ridge National Laboratory

\begin{tabular}{lcc}
\hline \multicolumn{1}{c}{ Title } & $\begin{array}{c}\text { TEC } \\
(\$ \times 1000)\end{array}$ & $\begin{array}{c}\text { Fiscal } \\
\text { year }\end{array}$ \\
\hline Upgrade stack fans (3039) & 740 & 1991 \\
Waste Operations Control Center expansion & 1196 & 1991 \\
Liquid/Gaseous Waste Support Facility & 1100 & 1992 \\
Upgrade Hot Off-Cias System at 3039 stack & 1100 & 1994 \\
Ventilation Systems upgrade (3500) & 1000 & 1995 \\
3039 stack support upgrade & 550 & 1995 \\
Upgrade 3047 Filter House & 1100 & 1997 \\
\hline
\end{tabular}

a'Total estimated cost. 

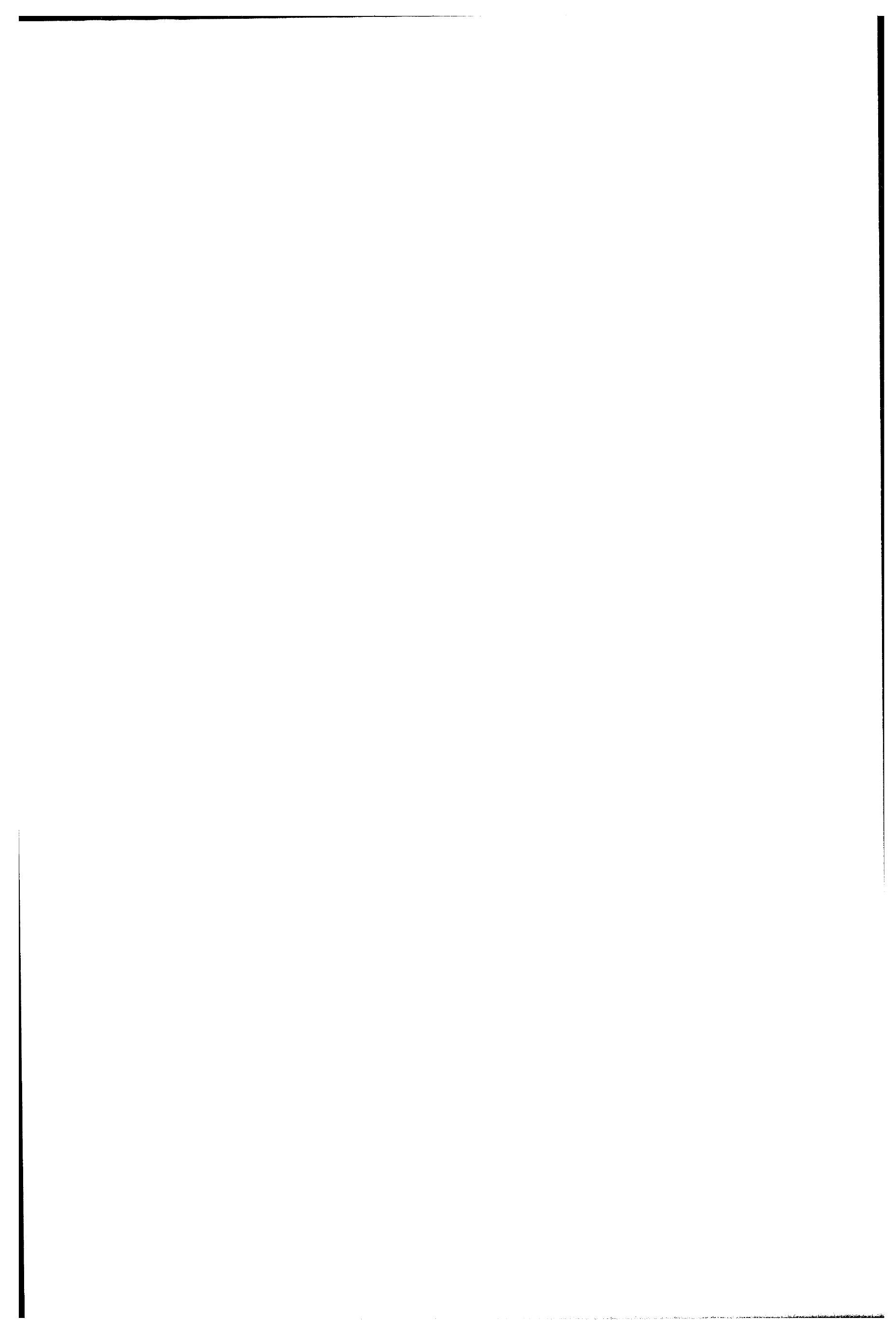


\section{HAZARDOUS WASTE}

The objective of the Oak Ridge National Laboratory (ORNL) Hazardous Waste Management Program is the compliant management of all nonradioactively contaminated hazardous wastes as defined by 40 CFR Pt. 261.3 under the Resource Conservation and Recovery Act (RCRA), Toxic Substances Control Act (TSCA) materials, and U.S. Department of Transportation (DOT) regulatory guidelines for poisonous substances that are currently under the control and cognizance of the Waste Management and Remedial Action Division. The management of hazardous waste is administratively regulated by the Tennessee Department of Environment and Conservation (TDEC), which has been authorized by the U.S. Environmental Protection Agency (EPA) to enforce RCRA.

When a waste or waste stream is generated, it must be determined if it is "hazardous" as defined above. This is done by applying the following general criteria (see 40 CFR Pt. 262.11 under "Hazardous Waste Determination"):

- Is the waste excluded from regulation?

- Is the waste listed as a hazardous waste (i.e., the waste or its constituents are specifically listed in the regulations as hazardous)?

- Is the waste a characteristically hazardous waste (i.e., the waste or its constituents exhibit any of the following characteristics: corrosivity, reactivity, ignitability, or toxicity)?

Note that the level of radioactive contamination present in or on a given waste will also have some bearing on how the waste is handled. Hazardous wastes found to contain any levels of radioactive contamination added by U.S. Department of Energy (DOE) operations are referred to as "mixed wastes" and are described in detail in Sect. 5 of this plan.

Because there is currently no procedure to determine absolutely that no radioactivity has been added (the "No Rad Added" policy), the distinction between hazardous waste and mixed waste has been blurred. However, this distinction is still made by the Hazardous Waste Operations Group (HWOG) based on "traditional" acceptable levels of radioactive contamination.

If a waste is determined to be a hazardous waste, it must be handled in strict accordance with RCRA. The principal RCRA requirements include proper characterization, storage, treatment, and disposal of hazardous waste in which all the attendant activities meet the letter of the law under RCRA. It is the policy of ORNL to handle all TSCA wastes in the same manner as RCRA except in those instances where TSCA regulations are more restrictive or require specific action pertaining to polychlorinated biphenyl (PCB) wastes.

\subsection{SOLID AND LIQUID WASTES}

Many independent research projects at ORNL are supported by numerous small scientific laboratories that store and use hazardous materials. Most of these laboratories are potential generators of hazardous waste such as spent experimental samples, process residuals, and hazardous materials (usually chemicals) that have exceeded their shelf lives or are no longer useful. Waste oil is generated from sources such as motor vehicles, machines, and vacuum pumps. Hazardous waste is also generated by the groups that support the research projects, such as photographic labs and reproduction facilities. Because liquid and containerized gaseous wastes are considered "solid" wastes by the EPA and are subject to 
solid waste rules, liquid, containerized, gaseous, and solid hazardous wastes are managed similarly at ORNL.

\subsubsection{Strategy}

The current strategy for hazardous waste management at ORNL is illustrated in Fig. 4.1. This management strategy is in compliance with applicable federal and state

ORNL.DWG 91M-15033R3

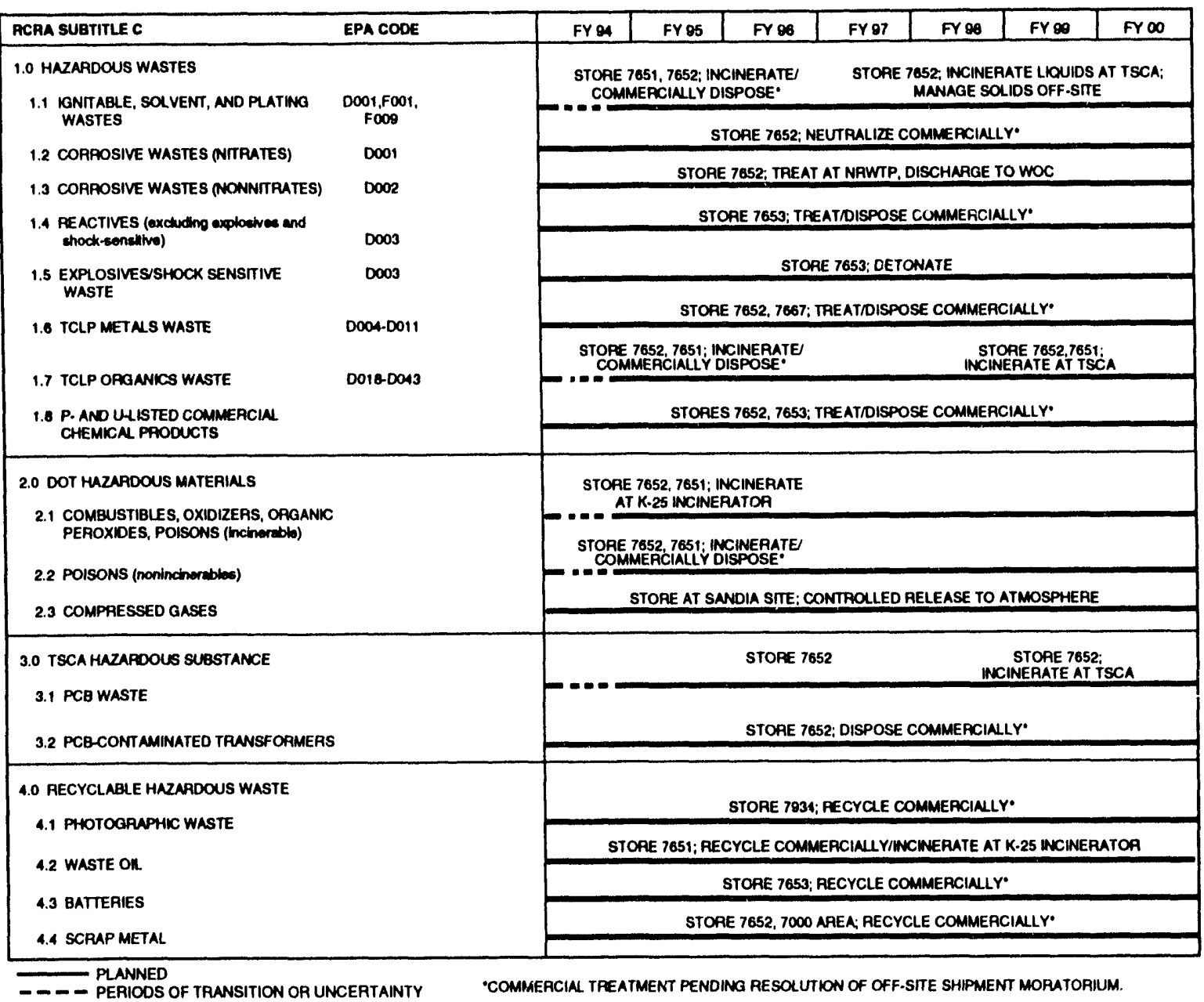

Fig. 4.1. Oak Ridge National Laboratory management strategy for hazardous waste.

regulations, DOE orders, and corporate policies. It is ORNL policy to manage hazardous waste in a manner to protect its employees, public safety and health, and the environment. Cost-effective options for the storage, treatment, and disposal of these waste streams are sought. Currently, ORNL hazardous waste is collected, handled, and stored with off-site treatment/disposal as the major waste management objective. The focus of hazardous waste management is characterization, verification, segregation, repackaging, and storage in preparation for shipment to commercial facilities for treatment and/or disposal. The suspension of off-site shipments in May 1991 continues to significantly affect this strategy. Waste reduction, tracking, and documentation are also critical aspects of the ORNL 
management strategy. A methodology for resuming off-site shipment and treatment is being developed. Success in this area will depend on improved certification and increased operational readiness review.

ORNL is committed to the reduction of the quantity and toxicity of the waste generated by its activities including functions directly related to its mission, supporting activities, and environmental remediation activities. Requirements for waste reduction are found in federal regulations and DOE policies and guidelines; motivation for waste reduction stem from increased costs and liabilities associated with the management of wastes and limited disposal options and facility capacities. See Sect. 9 for a description of ORNL's Waste Reduction Program.

\subsubsection{Generic Description and Characteristics of Waste}

Critical first steps in responsible waste management are the identification of waste streams and determination of their characteristics. These characteristics include physical form (i.e., liquid, solid, or gas), chemical properties, and/or the presence of constituents identified as hazardous by the EPA or the TDEC under the RCRA or by TSCA. Because ORNL is a research laboratory, its waste generation is quite different from that of a production facility. Generation is not linked to production rates; therefore, well-defined or regularly generated waste streams are in the minority. Instead, the diverse nature of ORNL's research and development activities produces a large number of widely varied waste streams. The fact that nearly all characteristically hazardous and listed hazardous wastes defined by the EPA and the TDEC appear on ORNL's RCRA Part A permit application illustrates this diversity.

Collection of hazardous waste at ORNL is performed in a proceduralized manner (see Fig. 4.2). The generator of a hazardous waste prepares a request form for waste collection. The request is sent to HWOG, which logs the request, ensures that the waste has been properly identified, and determines its appropriate classification (i.e., toxic, reactive, ignitable, etc.). For example, lab-pack and explosive wastes are collected and delivered directly to Building 7653 for storage in a predesignated area that corresponds to the waste classification. When enough is accumulated, lab-pack waste is packaged by commercial storage, treatment, and disposal facility personnel into appropriate shipping containers that meet DOT requirements and is shipped to EPA-permitted commercial treatment or disposal sites. Explosive waste is treated on-site at the Chemical Detonation Facility (Building 7667). Following waste classification and collection, bulk (drummed) liquid and solid hazardous wastes are delivered directly to Building 7652 to await off-site treatment or disposal. PCBcontaminated waste is collected for immediate delivery to Building 7507 and subsequent offsite treatment. Similarly, used oil acceptable for off-site recycle is delivered to Building 7651 for off-site processing.

\subsubsection{Treatment Facilities}

ORNL relies primarily on commercial facilities for the treatment of its hazardous wastes. Some waste treatment is provided on-site for a few waste categories (as is discussed in the following paragraphs).

Bulk non-nitrate acids are neutralized at the Nonradiological Wastewater Treatment Plant (NRWTP) and discharged to White Oak Creek via the National Pollutant Discharge Elimination System permit. This facility is a wastewater treatment unit operated under 


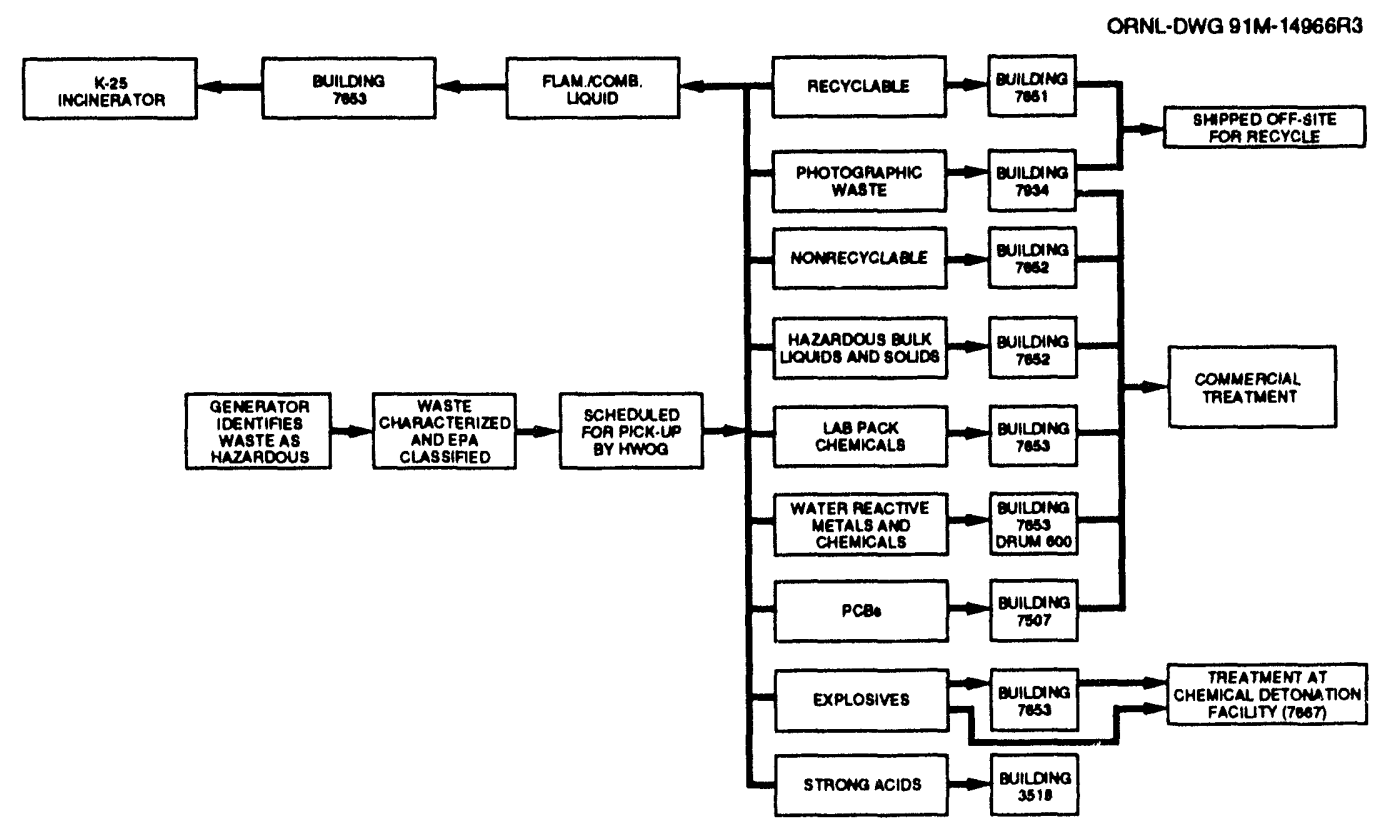

Fig. 4.2. Flowchart of hazardous waste management activities. EPA-U.S. Environmental Protection Agency; PCB-polychlorinated biphenyl.

Sect. 402 of the Clean Water Act and is exempt from RCRA permitting requirements for storage, treatment, and disposal facilities.

The Chemical Detonation Facility (Building 7667) is located $\sim 61 \mathrm{~m}(\sim 200 \mathrm{ft})$ northeast of the Hazardous Waste Management Area. Access to the site is from a gravel road (Chemical Waste Access Road) off the Health Physics Research Reactor (HPRR) access road. The site consists of two storage magazines (one for the detonation sheets and one for the electrical blasting caps), a detonation trench, and a control area (Fig. 4.3). The magazines are $\sim 1.2 \times 1.2 \times 1.2 \mathrm{~m}(\sim 4 \times 4 \times 4 \mathrm{ft})$ and are bulletproof, fire-resistant, weatherresistant, theft-resistant, and ventilated. The magazines are separated by an earthen berm $\sim 1.2 \mathrm{~m}(\sim 4 \mathrm{ft})$ high. The detonation trench is $1.2 \times 3 \times 1 \mathrm{~m}\left(4 \times 10 \times 3 \frac{1}{2} \mathrm{ft}\right)$. An $18.3-\mathrm{m}$ $(60-\mathrm{ft})$ radius around the trench is to be kept clear of combustible materials such as trees, brush, shrubs, and tall grass. The cleared area is enclosed by a chain-link fence. The control area is the location from which the waste material is remotely detonated. The cleared area provides good visual line of sight from the control area to the detonation trench.

The Chemical Detonation Facility operates under RCRA interim status permit and an open burning permit under TDEC regulations. A RCRA Part B, Subpart X, permit application has been prepared and submitted to the TDEC.

The Neutralization Facility is used for the treatment of Steam Plant demineralizer regenerant and some acid products. Once neutralized, the liquid effluent is directed to the NRWTP. 


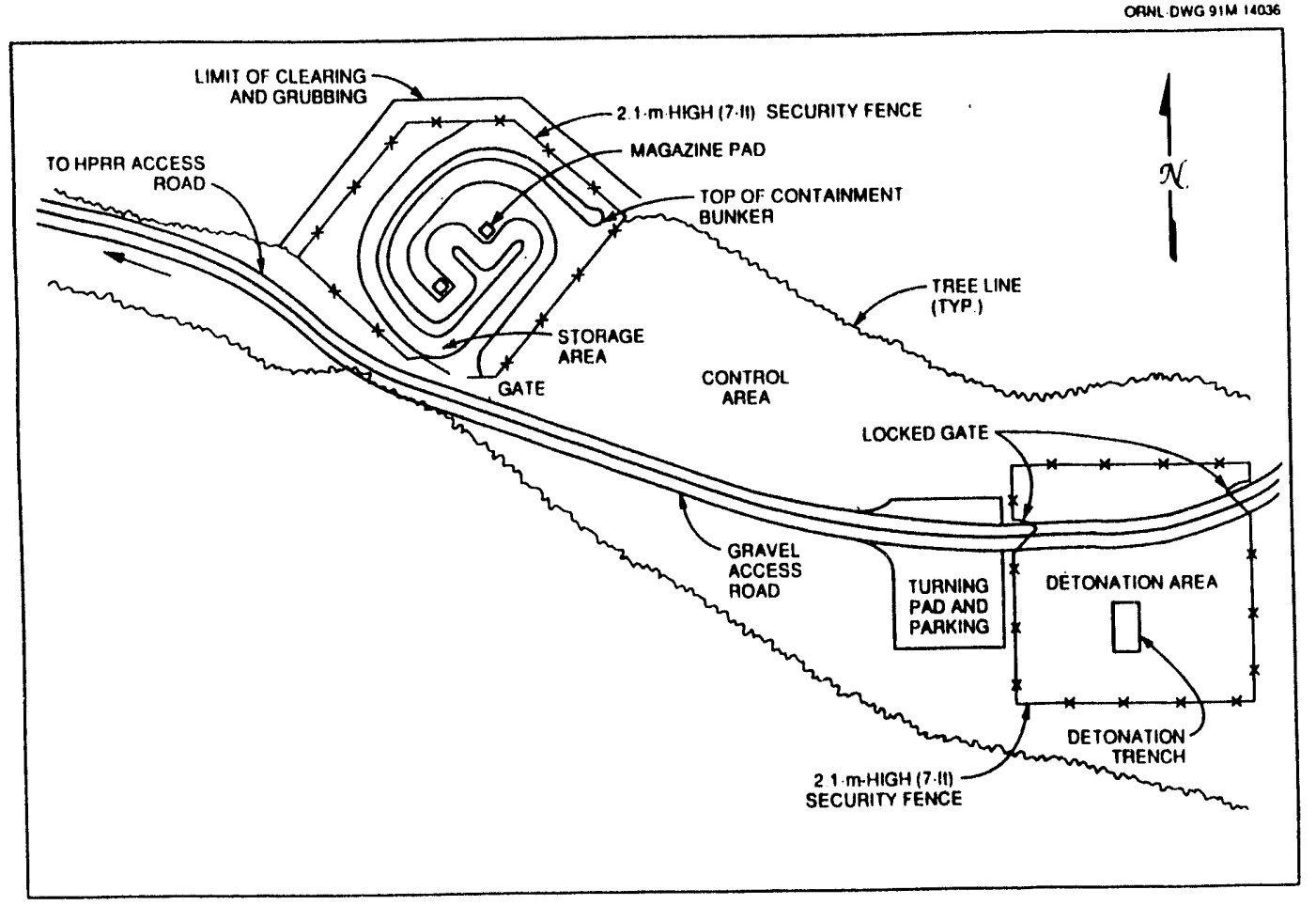

Fig. 4.3. Chemical Detonation Facility (Building 7667). HPRR-Health Physics Research Reactor.

\subsubsection{Storage Facilities}

Several facilities are currently used for the storage of hazardous waste at ORNL, as is discussed in the following subsections. The majority of waste is stored in 208-L (55-gal) drums in Building 7652; it has a capacity of $57,254 \mathrm{~L}(15,125 \mathrm{gal})$. Inventories of waste in the various storage facilities vary monthly because these areas are used for staging the waste for final disposition. With the exception of Buildings 7507 and 7934 , the storage facilities are located in the Hazardous Waste Management Area off the HPRR access road at ORNL.

\subsubsection{Building 7652-Hazardous Waste Storage Facility}

Building 7652 has an area of $\sim 223 \mathrm{~m}^{2}\left(\sim 2400 \mathrm{ft}^{2}\right)$ with dimensions of $11.9 \times 18.6 \mathrm{~m}$ $(39 \times 61 \mathrm{ft})$. This area includes an outside covered storage area $6 \times 9 \mathrm{~m}(20 \times 30 \mathrm{ft})$. The building consists of insulated, prefabricated panels and has metal stud walls with a 2 -h fire rating. The building floor is 3000-psi concrete and has two coats of an epoxy sealer; curbing is around the building. The enclosed section of the building consists of five storage areas, each of which contains a sump, and each area is separated by curbing. The building layout is shown in Fig. 4.4.

Building 7652 is used to store hazardous wastes that have been packaged, labeled, and marked in accordance with DOT regulations. The bulk waste chemicals are placed in DOT-certified drums either at their point of origin or after transfer to the facility. A maximum of $57,254 \mathrm{~L}(15,125 \mathrm{gal})$ [275 208-L (55-gal) drums] can be stored at this facility. Drums stored in this building are segregated according to the compatibility groupings. When 


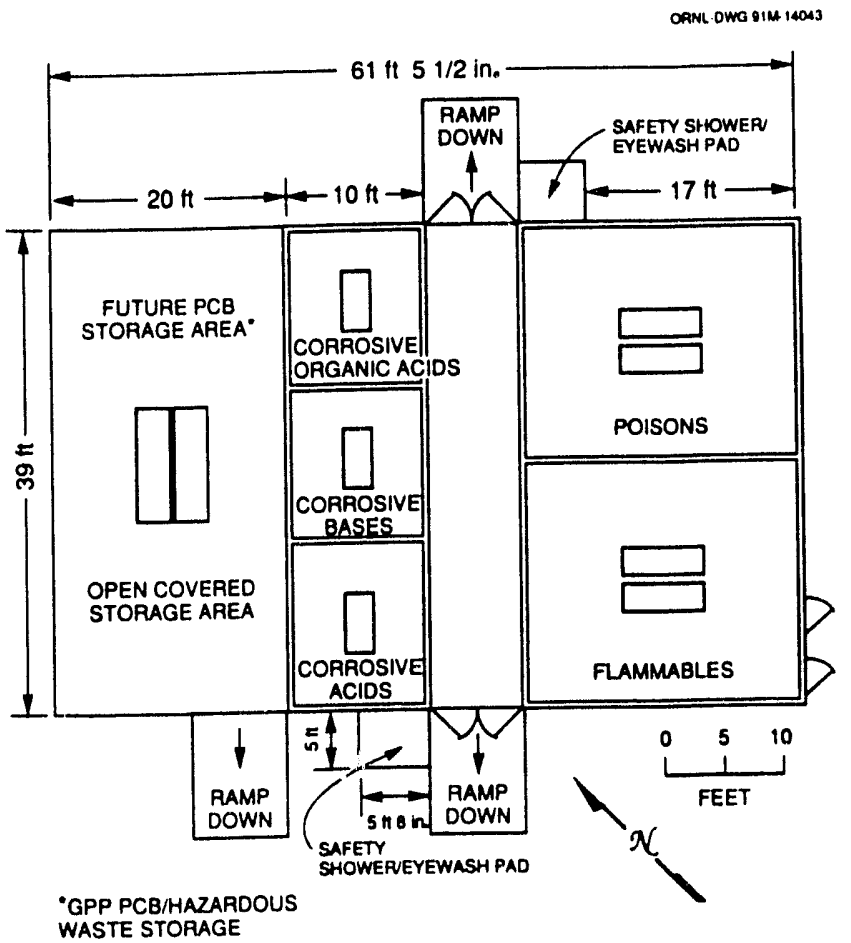

Fig. 4.4. Layout of the Hazardous Waste Storage Facility (Building 7652).

a sufficient quantity of waste to facilitate proper management is accumulated, shipment and transfer is arranged to an off-site EPA-permitted storage, treatment, and disposal facility.

\subsubsection{Building 7653 - Chemical Waste Storage Facility}

Building 7653 is $9 \times 31 \mathrm{~m}\left(30 \times 102 \mathrm{ft} 8 \mathrm{in}\right.$.) and has a total area of $285 \mathrm{~m}^{2}$ $\left(3060 \mathrm{ft}^{2}\right.$ ). The building is divided into eight separate rooms (storage room). The building layout is shown in Fig. 4.5. The building is constructed of insulated prefabricated metal framing, partitioned with metal stud walls having a 2 -h fire rating. Curbing with a centralized sump is utilized for each of the storage rooms (except for the water reactive storage room). One of the rooms is used for an office and emergency equipment storage area.

The facility is used for storage of small containers of laboratory chemicals and process chemical wastes. The small containers [less than $18.9 \mathrm{~L}(5 \mathrm{gal})$ or $20 \mathrm{lb}$ ] of chemical wastes are delivered to the facility and are separated by compatibility grouping for storage in the appropriate room. The storage rooms contain metal shelving or cabinets to hold the containers. The chemicals are generally within the manufacturer's original container and are identified with the manufacturer's label. When a quantity of waste sufficient to facilitate proper management is accumulated, personnel from an Energy Systems-contracted commercial storage, treatment, and disposal facility lab-pack the waste into DOT-certified containers. The waste is then shipped off-site to an EPA-permitted storage, treatment, and disposal facility.

Each storage room is physically limited to contain not more than the equivalent number of small containers constituting $10208-\mathrm{L}$ (55-gal) drums. The maximum allowed 
ORNL DWG. $84-12325$

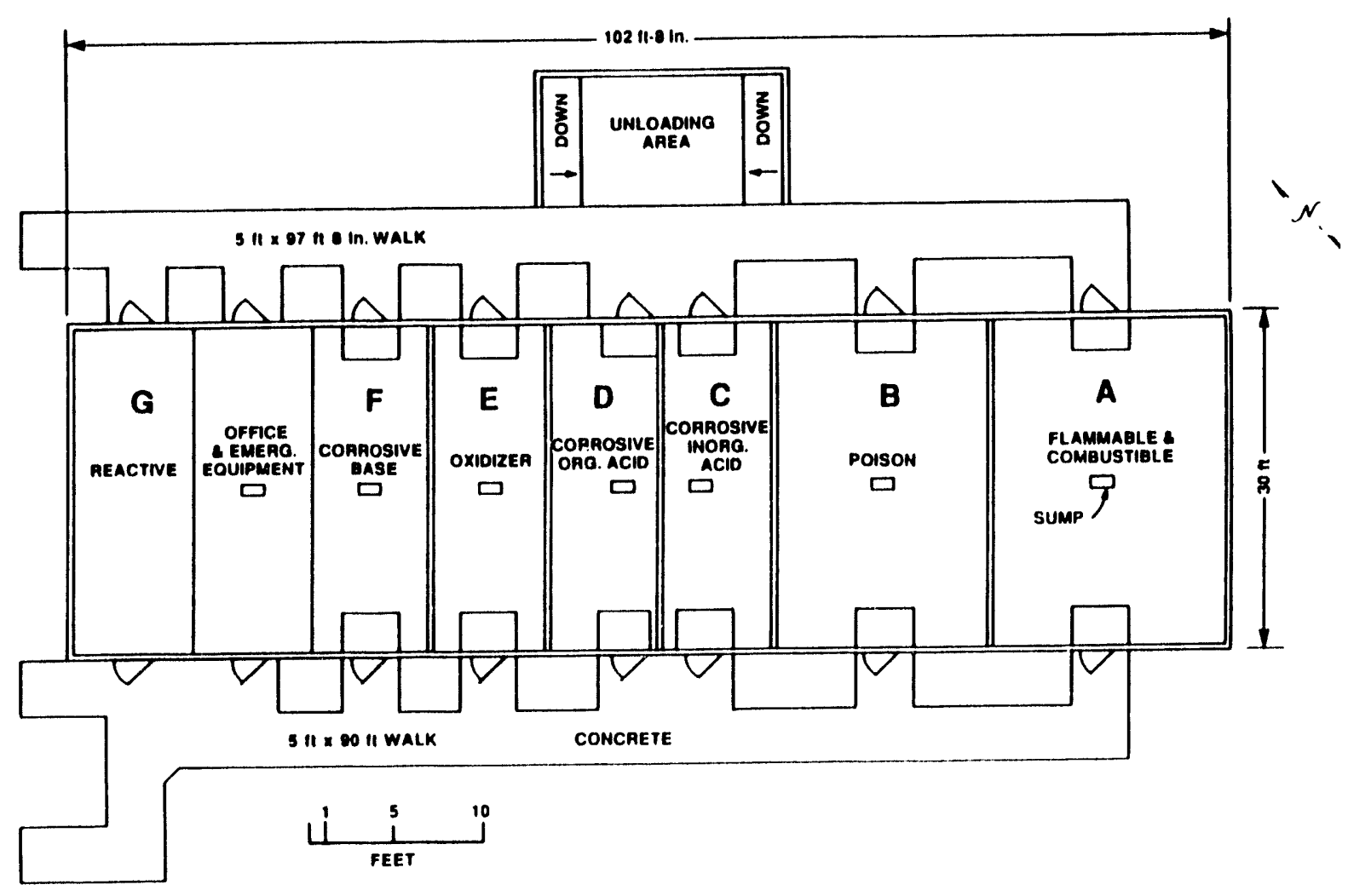

Fig. 4.5. Layout of the Chemical Waste Storage Facility (Building 7653).

inventory of waste in storage for the facility at any given time is the equivalent of $70208-\mathrm{L}$ (55-gal) drums, or 11,546 L (3850 gal).

\subsubsection{Building 7507-Hazardous Waste Storage Facility}

Building 7507 is a steel frame, metal siding structure consisting of $\sim 136.7 \mathrm{~m}^{2}$ $\left(\sim 1470 \mathrm{ft}^{2}\right)$ in an area that has a continuous concrete curb dike around the inside perimeter and no floor drains (Fig. 4.6). Double sliding doors with a metal ramp allow for loading and unloading operations. A portable, plastic containment system forms the storage area.

The maximum allowed inventory of hazardous waste in storage is $150208-\mathrm{L}$ (55-gal) drums, or 31,230 L (8250 gal). Initially, hazardous waste stored at the facility consisted of lab packs; bulk quantities of ignitable, corrosive, and/or extraction procedure toxic wastes, oxidizers, and poisons; and PCB-contaminated liquids and solids. Currently, the storage facility is utilized to store only PCB and PCB-contaminated waste. However, the PCB waste may also be identified as exhibiting a characteristic of hazardous waste.

\subsubsection{Building 7651-Clean Oil Storage Pad}

Building 7651 is a $12 \times 6 \mathrm{~m}(40 \times 20 \mathrm{ft})$ concrete pad covered with a ribbed metal decking roof. A continuous concrete curb dike is in place around the perimeter of the pad. 


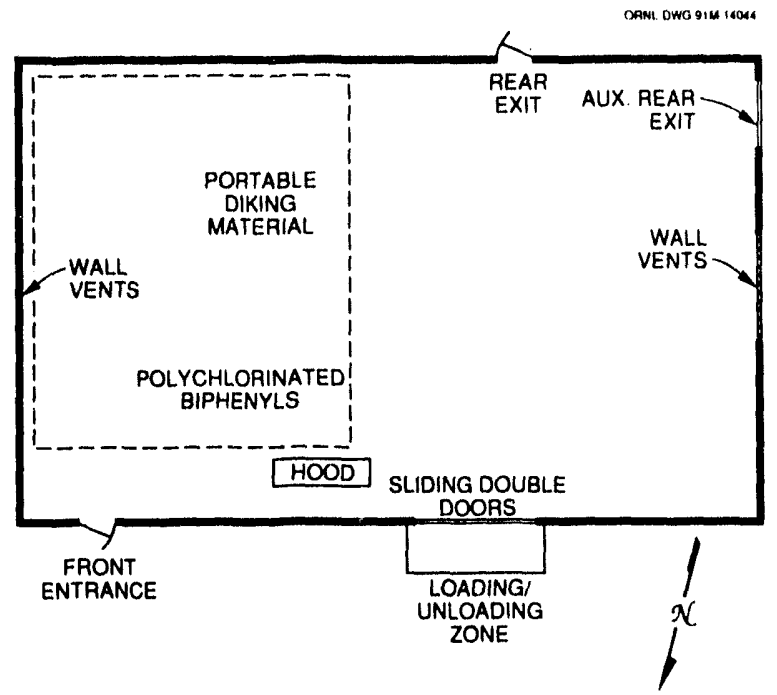

Fig. 4.6. Layout of the Hazardous Waste Storage Facility (Building 7507).

No floor drains or sumps exist at the pad. Ramps are provided for equipment access onto the pad (see Fig. 4.7).

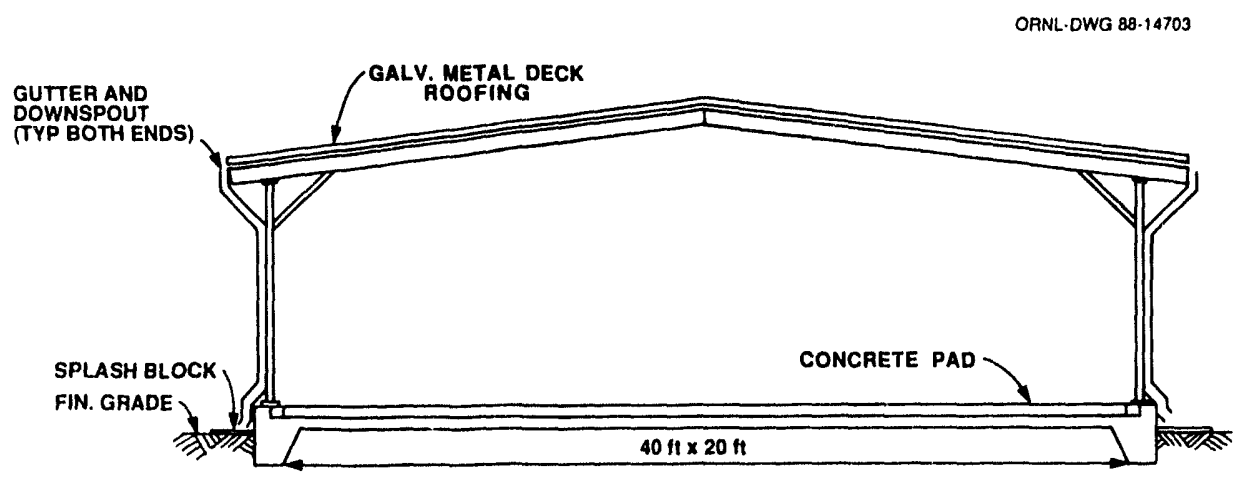

Fig. 4.7. Layout of the Clean Oil Storage Pad (Building 7651).

The storage pad is used to store 208- and 114-L (55- and 30-gal) drums containing used oil acceptable for unrestricted off-site release. The maximum inventory of waste in storage is 128 208-L (55-gal) drums, or 26,649 L (7040 gal). Drums are placed on pallets and double-stacked, if required, with pallets between each level. The drums are arranged in rows to provide walkway space for emergency personnel and equipment and conducting inspections.

\subsubsection{Building 7934-Hazardous Waste Storage Facility}

Located in the High Flux Isotope Reactor Complex, this facility is generally used to store photographic wastes that are shipped off-site for silver recovery, but future storage may also include hazardous and/or mixed wastes such as scintillation fluids, used oils, lab-pack chemical wastes, or other RCRA-regulated materials. Wastes are generally stored in DOTapproved containers [typically 114- or 208-L (30- or 55-gal), or overpack drums], but other containers may be used. Building $7934[14.6 \times 14.9 \mathrm{~m}(48 \times 49 \mathrm{ft})]$ is made of a 


\section{$4-11$}

prefabricated metal frame with metal walls and roof. Ramps are provided for equipment access into the unit.

\subsubsection{Environmental monitoring}

At the various ORNL hazardous waste storage facilities, the building dikes and sumps are maintained to prevent cracks and leaks. Any spill in a drum loading area or storage area is removed immediately to prevent further contamination. Containers are always closed during storage and handled in a manner to prevent leakage. In the event of a spill or release to the environment outside the facility, the ORNL Contingency Plan (discussed in The Spill Prevention, Control, Countermeasures, and Contingency Plans for Oak Ridge National Laboratory) would be activated.

\subsubsection{Permitting status}

A revised RCRA Part B permit application was submitted to the TDEC in August 1993. This application covers all hazardous and mixed waste storage units at ORNL, including Buildings $7651,7652,7653,7654,7507,7507 \mathrm{~W}, 7934$, and proposed facilities (Buildings 7668 and 7669).

\subsubsection{Facility status}

An upgrade of Building 7507 is planned to provide additional storage space for contaminated lead awaiting decontamination for reuse (see Subsect. 5.1.4.7). Another FY 1990 general plant project (GPP) involves the upgrade of Building 7652 to increase PCB storage space. Previously scheduled for completion by the end of CY 1991, this project has been delayed because the space provided by Building 7652 cannot be spared at present.

\subsubsection{Disposal Facilities}

Hazardous waste at ORNL is collected, identified, and packaged for off-site shipment to EPA-permitted treatment and/or disposal sites. No on-site disposal facilities for hazardous waste exist at, or are planned for, ORNL. Moreover, no hazardous wastes are allowed to be shipped off-site until the "No Rad Added" policy has been established.

\subsubsection{Status of Support Systems}

\subsubsection{Training}

The RCRA Waste Management Operations training course is required of all employees working at waste management facilities at ORNL permitted under RCRA. The objective of this training is to familiarize the employees with operating procedures, emergency procedures, emergency equipment, and emergency systems. The training also provides instruction on the procedures for handling of hazardous wastes; procedures for using, inspecting, repairing, and replacing emergency and monitoring equipment; communication or alarm systems; response to fires or explosions; response to hazardous material spills; and shutdown of operations. The training includes a written examination that is retained on file at ORNL. 
Hazardous waste generator training is required for generators of hazardous waste. Two courses are provided for hazardous waste generators: (1) "Waste Generator Training for Satellite Accumulation Areas" and (2) "Waste Generator Training for 90-Day Accumulation Areas." Specific guidance is given on identification and segregation of hazardous waste, requirements for management of accumulation areas, and correct completion of Form UCN-13698, "Uniform Request for Disposal."

The waste minimization training course is recomımended for generators of all wastes. Specific guidance is given on what waste minimization is, why it is a goal at ORNL, who is responsible for implementing waste minimization efforts, how it can be implemented in the divisions, and what each employee's role is in implementing waste minimization. In addition to the formal training programs, an employee awareness program is in progress. The campaign to heighten sensitivity to waste minimization concerns includes such things as announcements in internal publications and publicity for programs or projects that have been successful in minimizing waste production. Part of this campaign also inciudes an incentive program that will recognize individual ORNL employees who provide waste minimization suggestions.

\subsubsection{Certification}

ORNL is able to characterize its hazardous waste through (1) knowledge of the generating processes, (2) knowledge of the waste, and/or (3) analysis of the waste. Steps in the waste-handling procedure include (1) request for waste disposal (completion of Form UCN-13698), (2) notification for radiation survey, (3) review of Form UCN-13698 by the HWOG, (4) waste sampling according to the Waste Analysis Plan, (5) waste analysis using EPA-approved procedures, (6) waste classification according to EPA and DOT classes, (7) waste inspection and preparation for transport, (8) waste pickup by the HWOG, (9) onsite transport to storage facilities, (10) packaging and labeling for off-site shipment, (11) onsite storage or treatment, (12) data entry into the tracking system, and (13) off-site shipment for treatment/disposal.

Detailed procedures for managing hazardous waste including characterization and certification activities are contained in the ORNL Hazardous Waste Operations Manual. During FY 1993 a formal certification program for ORNL hazardous waste was developed. As part of this program, the requirement for generator certification (including training) was formalized.

\subsubsection{Database management}

Information on hazardous waste handled at ORNL is maintained on a variety of computer databases. In general, these databases track generation, storage, and disposal of hazardous waste. Examples of these databases include the Hazardous Waste Tracking System (HWTS) and the PCB Tracking System (PCBTS). Both databases are on-line, user friendly information systems that operate on the DEC System-10 computer using System 1022 as the database management system. Each of these is described briefly in the following paragraphs.

ORNL's HWTS was developed in 1982 in response to a recognized need for a system to track hazardous wastes from generation to disposal. The HWTS was designed and developed as a joint effort between staff in the Environmental Compliance Section within the Office of Environmental Compliance and Documentation and the Computing and Telecommunications Division. HWTS management ard maintenance functions are now carried out by HWOG. 
The purpose of the HWTS is to aid ORNL staff in managing its waste disposal program and in complying with reporting requirements within safety and environmental regulations. The system provides file maintenance capability, record query, and management information reporting. Monthly billings, annual summaries of waste handling, and division generation quantity totals are among the reports that are generated routinely. The annual summary reports generated by the system include the hazardous waste stream report, the offsite shipping report, and the detailed report for storage, treatment, disposal, and recycle facilities. Other reports required by management can be programmed by Computing and Telecommunications Division personnel. Output can be to the terminal or to a disk file for subsequent printing.

To ensure accuracy of the data within the system for reportıng purposes, extensive data validation is conducted by the staff in the Environmental Compliance Section and HWOG. Four different data files are used within the system including waste item information, waste composition for mixtures, radioactive waste information, and general account information. Input data for the waste item file include (1) form number; (2) DOT shipping name and number; (3) EPA classification; (4) in-house charge number; (5) item number from the in-house waste disposal form; (6) waste description; (7) radioactivity type and level; (8) EPA hazardous waste number(s); (9) volume or weight; (10) storage site and date; (11) disposal site, date, and container number; and (12) plant of origin. The new Request for Disposal Form has many more fields than these and are too numerous to list here. If the waste is a mixture, then several individual components can be listed. The account information is used to bill generators for the costs incurred by HWOG in the pickup and storage of waste. Because of the large volume of information tracked on the system, users typically have access to 3 calendar years of data. Older data files have been downloaded onto tapes but can be accessed on request to the Computing and Telecommunications Division.

PCBTS, the second hazardous waste database, is comprised of two submodules: (1) inventories of equipment in service, removed from service, or transported for disposal and (2) waste generation and disposal. The equipment inventoried includes transformers and large high- and low-voltage capacitors as well as miscellaneous hydraulic equipment that contain $>2$ ppm PCBs. The records on the PCB-contaminated equipment are maintained by the Environmental Compliance Section. Records for the second module of the PCBTS, the PCB waste database, cover generation and disposal of both PCBs and PCB-contaminated wastes. The PCB waste submodule receives storage and shipment data from the HWTS. The PCB waste data, compiled by HWOG, include (1) waste descriptions, (2) dates and quantities of PCBs and PCB-contaminated wastes transferred into or out of storage during a given year, and (3) those retained in storage at the end of a year.

\subsubsection{General Plant Projects}

A listing of the proposed GPPs for hazardous waste facilities at ORNL is provided in Table 4.1. This table indicates the project title, total estimated cost, and respective fiscal year for funding.

\subsection{GASEOUS WASTE}

A wide variety of research and operational activities at ORNL utilize compressed gases that are procured in cylinders. When empty, the cylinders are usually returned to the 
Table 4.1. General plant project for hazardous waste facilities at Oak Ridge National Laboratory

\begin{tabular}{lcc}
\hline \multicolumn{1}{c}{ Title } & $\begin{array}{c}\text { TEC }^{\circ} \\
(\$ \times 10(0))\end{array}$ & $\begin{array}{c}\text { Fiscal } \\
\text { year }\end{array}$ \\
\hline $\begin{array}{l}\text { Polychlorinated } \\
\text { hiphenyl/hazardous waste } \\
\text { storage. Building } 7652 \text { Annex }\end{array}$ & $\$ 200$ & 1989 \\
\hline
\end{tabular}

"Total estimated cost.

distributor, and a deposit fee is refunded. However, some cylinders become damaged and cannot be returned to the vendors. The most frequent damage is in the form of stuck or leaking valves.

\subsubsection{Strategy}

The management strategy for the treatment of damaged gas cylinders at ORNL (Fig. 4.2) is to maintain facilities (1) in compliance with RCRA requirements for handling of hazardous gases and disposal of "empty" containers, (2) in compliance with the Clean Air Act (CAA) as amended in 1990 (including Title III for Hazardous Air Pollutants) and associated state permitting requirements and conditions, (3) in compliance with DOT regulations (leaking cylinders cannot be knowingly transported), (4) in compliance with Occupational Safety and Health Administration (OSHA) right-to-know requirements, (5) with protection for workers from physical and chemical hazards, and (6) with a costeffective solution for treatment. The current strategy involves the venting of compressed gases to the atmosphere in an isolated area in accordance with regulations and in a way that protects worker safety and health as well as the environment.

\subsubsection{Generic Description and Characteristics of Waste}

HWOG receives damaged cylinders and manages them as hazardous waste. Excess gas cylinders that are not returnable are also managed as hazardous waste. Data supplied by the generator are entered into the HWTS. Volumes of gas cylinders vary from 0.028 to $1.4 \mathrm{~m}^{3}\left(1\right.$ to $\left.50 \mathrm{ft}^{3}\right)$. A wide variety of gases are contained including oxygen, nitrogen, hydrogen, acetylene, propane, chlorine, ammonia, freon, and sulfur hexafluoride. Approximately 12 leaking cylinders are handled per year.

When a gas cylinder is found to be damaged or leaking, the generator notifies HWOG. HWOG determines if the cylinder poses a potential hazard or emergency. If the gas cylinder does not represent an emergency, HWOG removes the cylinder and transfers it to the Leaking Gas Cylinder Area.

If the gas cylinder does represent an emergency, HWOG immediately removes the cylinder and places it in the Leaking Gas Cylinder Area. As time permits, the generator completes a Request for Disposal Form. After the cylinder has bled off, it is returned to the vendor or stored until disposed of in accordance with applicable requirements. The Leaking Gas Cylinder Area is described in the following paragraphs. 


\subsubsection{Treatment Facilities}

The Leaking Gas Cylinder Area at ORNL is used for the venting of damaged and excess gas cylinders. This area is located at a remote site (i.e., away from inhabited areas) off of Ramsey Drive and the Melton Valley access road. The area consists of a cleared site covered with gravel and surrounded by a fence with a locked gate. The cylinders are held in the area until the contents have bled off. Afterwards, the undamaged cylinders are returned to the vendors, and the damaged cylinders (except for radioactive) are stored until properly disposed of at the Oak Ridge Y-12 Plant Sanitary Landfill II (SLF II).

\subsubsection{Environmental monitoring}

Other than overall site monitoring requirements, direct monitoring of the environment at the Leaking Gas Cylinder Area is not required. Personnel monitoring is conducted during these operations to ensure worker safety pursuant to OSHA standards.

\subsubsection{Permitting status}

The provisions of the CAA are regulated by the TDEC through the Tennessee Air Pollution Control Regulations. The primary means of control is through the issuance of state air permits. The TDEC has indicated that the Leaking Gas Cylinder Area is exempt from permit requirements. RCRA permitting is not required for the venting of gas cylinders onsite.

\subsubsection{Facility status}

ORNL does not plan to build any new facilities for storing, treating, or disposing of gas cylinders unless specific problems are identified with respect to current air pollution control regulations. Therefore, the current practice of venting cylinders at the Leaking Gas Cylinder Area will continue as previously discussed.

\subsubsection{Storage and Disposal Facilities}

No storage or disposal facilities currently exist specifically for gaseous hazardous waste at ORNL. Upon generation, gas cylinders are either returned to the vendor or released at the Leaking Gas Cylinder Area. Empty damaged cylinders (except for radioactive) are discarded in the SLF II.

\subsubsection{Status of Support Systems}

The training courses, certification information, and database management systems discussed in Subsect. 4.1.6 of this plan regarding solid and liquid hazardous waste also pertain to gaseous hazardous waste at ORNL.

\subsubsection{General Plant Projects}

No GPPs are currently planned for hazardous gaseous wastes. 



\section{MIXED WASTE}

Radioactively mixed waste, referred to as mixed waste, is waste that is simultaneously regulated under the Resource Conservation and Recovery Act (RCRA) and under the Atomic Energy Act (AEA) as administered by the U.S. Department of Energy (DOE). Because these two bodies of regulations are not necessarily consistent or in agreement in every aspect of mixed waste management, special problems arise that are not a factor in the management of purely radioactive wastes or hazardous wastes. The majority of these problems stem from the fact that the normal resources available for radioactive or hazardous wastes are not open to mixed wastes. For example, most RCRA treatment, storage, and disposal facilities do not accept mixed wastes because they have no treatment or handling capability for radionuclides in their processes. Similarly, mixed wastes may not be routinely disposed in a similar fashion to that of radioactive wastes because of land disposal restrictions (LDRs) imposed by RCRA. As a result of this situation, mixed waste management has become a challenging area in the Waste Management and Remedial Action Division's overall waste management mission.

\subsection{SOLID AND LIQUID WASTES}

Typical waste items comprising Oak Ridge National Laboratory's (ORNL's) mixed waste stream are similar to many of the wastes described in Sects. 3 and 4 of this plan. In many cases a known radioactive waste will be determined to be a hazardous waste as well by knowledge of the process that generated it or by testing for a hazardous characteristics. Yet in other cases a waste known to be hazardous will be suspected of containing radioactive contamination and will be handled as a mixed waste. Still, in other situations, such as in the case of scintillation cocktails, a waste will be known to be a mixed waste at the time of generation. Table 5.1 indicates the annual generation rate and storage inventory of mixed waste from the Monthly Operations Report. Figure 5.1 provides a broad categorization of ORNL's mixed waste streams.

Table 5.1. Solid waste generated and handled at Oak Ridge National Laboratory during FY 1992 and FY 1993

\begin{tabular}{ccc}
\hline \multirow{2}{*}{ Waste stream } & \multicolumn{2}{c}{ Quantity } \\
\cline { 2 - 3 } & FY 1992 & FY 1993 \\
\hline Mixed low-level & $21,525 \mathrm{~kg}(47,441 \mathrm{lb})$ & $24,423 \mathrm{~kg}(53,838 \mathrm{lb})$ \\
\hline
\end{tabular}

\subsubsection{Strategy}

The three activities into which the strategy for mixed waste management at ORNL can be summarized are:

- Characterization. Many of the mixed wastes currently being stored in ORNL facilities have not been fully characterized. Some of these wastes may not have a hazardous or radioactive component, in which case they may be removed from mixed waste 


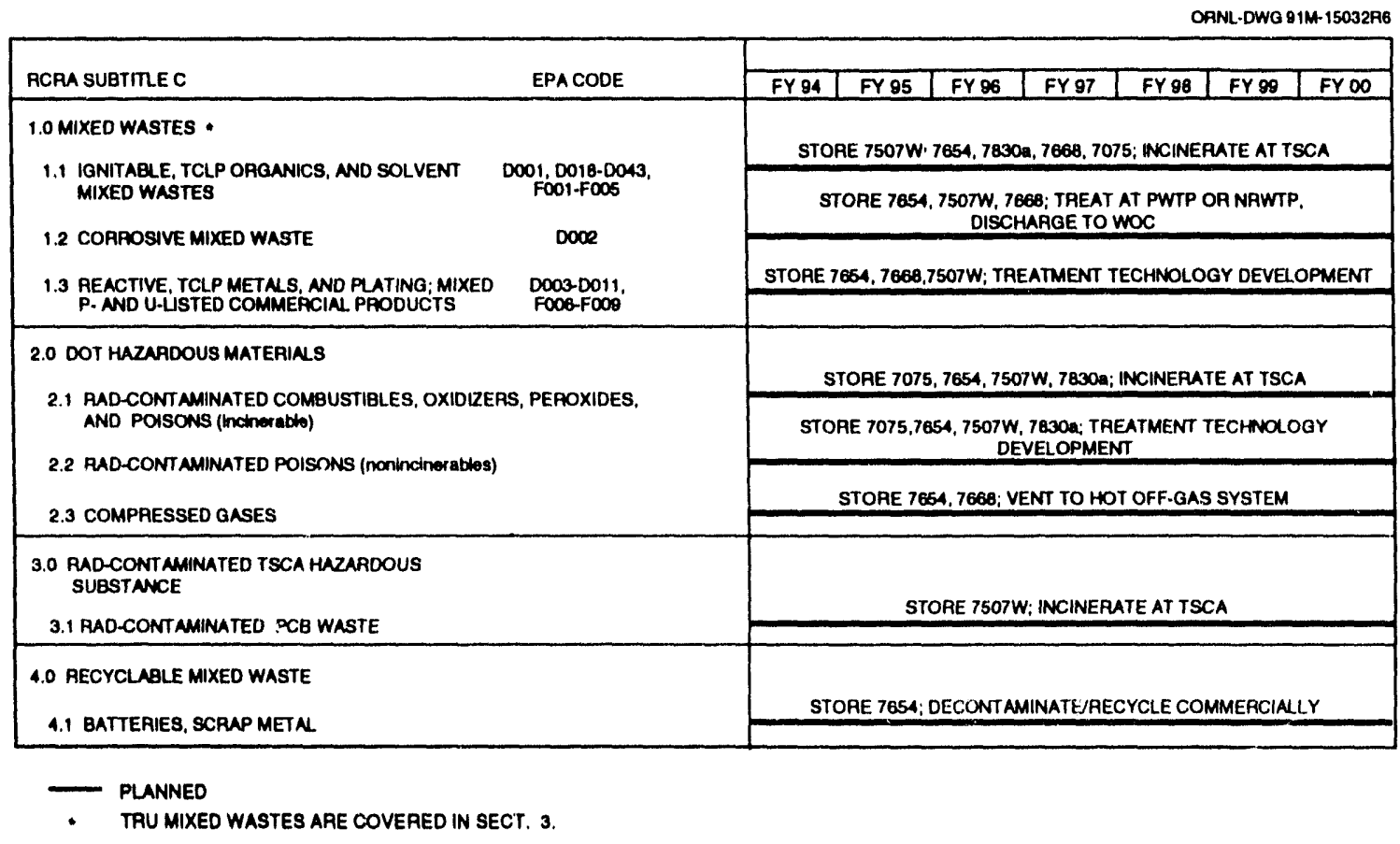

Fig. 5.1. Oak Ridge National Laboratory management strategy for mixed waste.

management. Characterization is also necessary to prepare wastes for eventual treatment either at DOE-owned facilities or in the private sector.

- Waste minimization. Waste minimization or source reduction of waste is being applied at the generator level to reduce the amount of mixed waste generated. This activity is described in more detail in Subsect. 9.2 of this plan.

- Federal Facilities Compliance Agreement (FFCA). On May 8, 1992, the RCRA LDR rule prohibiting the land disposal of untreated mixed wastes became effective. This development prompted the signing of an FFCA between the U.S. Environmental Protection Agency (EPA) and DOE to provide a system of schedules and milestones intended to bring ORNL into compliance with RCRA LDR. The primary deliverables for the FFCA are a Waste Treatment Plan, a Waste Treatment Strategy Plan, a Waste Minimization Plan, and a Waste Storage Plan.

\subsubsection{Generic Description and Characteristics of Waste}

The two major types of mixed wastes generated at ORNL are mixed waste oils and scintillation fluids. Mixed waste oils are sometimes generated when oils are removed from systems that have operated in radiation environments. Radiation levels in these oils is typically low $(\leq 10 \mathrm{mrem} / \mathrm{h})$. ORNL's generation rate for waste oils is quite variable. These wastes largely consist of vacuum pump oil, axle oil, refrigeration oil, mineral oil, or oil/water mixtures. Radioactive contaminants ${ }^{14} \mathrm{C},{ }^{3} \mathrm{H},{ }^{238} \mathrm{U},{ }^{239} \mathrm{Pu},{ }^{232} \mathrm{Th},{ }^{137} \mathrm{Cs},{ }^{60} \mathrm{Co}$, and ${ }^{90} \mathrm{Sr}$ are more common. In the last 3 years ${ }^{210} \mathrm{~Pb}$ and ${ }^{85} \mathrm{Kr}$ have been extremely rare. Radioactivecontaminated oils are being handled as RCRA waste. The strategy for dealing with these oils may continue to change as new EPA regulations on used oils are issued. 
The principal components of scintillation fluids are toluene and/or xylene, culture medium, miscellaneous organics, and various radioisotopes including ${ }^{3} \mathrm{H},{ }^{14} \mathrm{C},{ }^{32} \mathrm{P}$, and ${ }^{131} \mathrm{I}$. The maximum radiation surface dose rate on each container is limited to $10 \mathrm{mrem} / \mathrm{h}$. The flash point is normally less than $60^{\circ} \mathrm{C}\left(140^{\circ} \mathrm{F}\right)$; therefore the waste is classified as ignitable. Other mixed wastes at ORNL include organic wastes, carcinogenic wastes, mercurycontaminated solid wastes, waste solvents, corrosives, poisons, and other process wastes.

No hazardous wastes are permitted in transuranic (TRU) waste packages unless contaminated with TRU material, in which case the package must be labeled appropriately, and the hazardous waste must be treated or packaged to ensure no degradation of the waste container over its design life. Further discussion of the management of TRU mixed waste (generally lead and mercury) is presented in Subsect. 3.1.1 of this plan.

Although little has been generated to date, radioactively contaminated soils with hazardous components are expected to be generated from construction, demolition, and site remediation activities. The potential exists for generation of large quantities of soils containing mercury, lead, and/or organic contaminants.

\subsubsection{Treatment Facilities}

ORNL has no facilities specifically designed for the treatment of mixed waste. Corrosive mixed waste is scheduled for treatment at the Liquid Low-Level Waste (LLLW) System or the Process Waste Treatment Plant. Organic mixed wastes are planned to be treated at the Toxic Substances Control Act (TSCA) incinerator (Oak Ridge K-25 Site) per the RCRA LDR FFCA Treatment Plan. Also, mixed waste treatment is being discussed using other methods for the future.

\subsubsection{Storage Facilities}

Mixed waste is stored at several facilities at ORNL. Drum storage for solid and liquid mixed waste is currently being utilized at Buildings 7823,7654 , and $7507 \mathrm{~W}$, as is outlined in the following subsections. Bulk storage of waste oils is also provided by tanks 7075 and $7830 \mathrm{a}$ [total storage capacity $34,826 \mathrm{~L}$ (9200 gal)]. Tank 7860a was used for mixed oily waste until early 1991 when the contents were transferred to tank $7830 \mathrm{a}$.

\subsubsection{Building 7654—Long-Term Hazardous Waste Storage Facility}

Building 7654 is located in the Hazardous Waste Management Area off the Health Physics Research Reactor access road and has an area of $\sim 158 \mathrm{~m}^{2}\left(\sim 1700 \mathrm{ft}^{2}\right)$ with dimensions of $11.9 \times 12.8 \mathrm{~m}(39 \times 42 \mathrm{ft})$. The building consists of insulated, prefabricated panels built on a concrete floor surrounded by $15.3-\mathrm{cm}(6-\mathrm{in}$.) curbing. The inside of the building is divided into five storage areas, each having a centrally located sump and divided by curbing. An elevated aisle divides the building with three storage areas on one side and two storage areas on the other side. The building layout is shown in Fig. 5.2.

Building 7654 is used for storage of mixed LLWs, the majority of which are bulk scintillation fluids and scintillation vials. The majority of mixed wastes that are transported to Building 7654 are contained in 208-L (55-gal) drums. Occasionally, 114-L (30-gal) drums and smaller containers are received. Containers smaller than $114 \mathrm{~L}(30 \mathrm{gal})$ are either combined with compatible waste or lab-packed. The maximum inventory of drums in storage at any given time is 300 ; total capacity is $62,459 \mathrm{~L}(16,500$ gal). Double-stacking of 


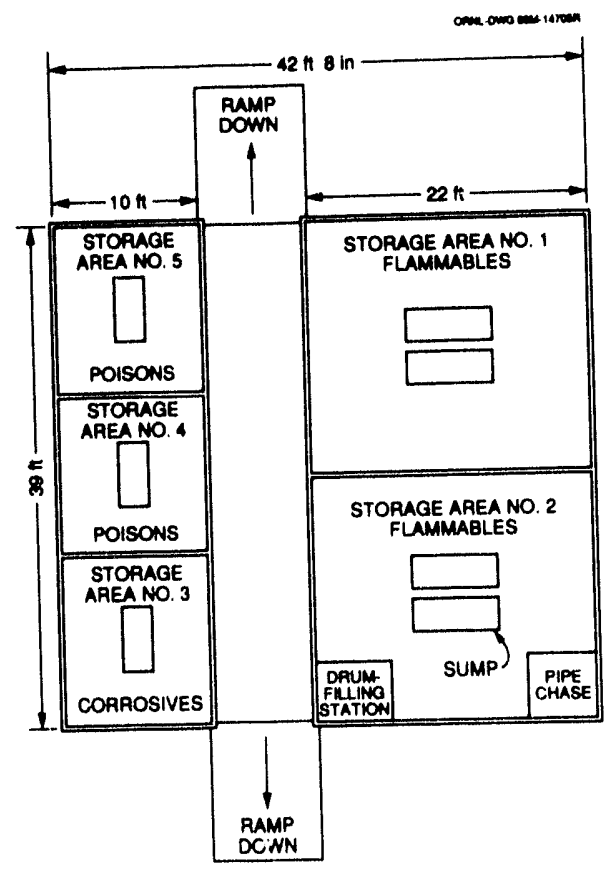

Fig. 5.2. Layout of the Long-Term Hazardous Waste Storage Facility (Building 7654).

drums is employed to maintain adequate aisle space. Pallets are placed between the double layers of drums.

\subsubsection{Building 7507W-Mixed Waste Storage Pad}

Building $7507 \mathrm{~W}$, located within the ORNL Complex, is a metal-covered $3.7-\mathrm{m}^{2}$ $\left(40-\mathrm{ft}^{2}\right)$ concrete pad with a $0.10-\mathrm{cm}(4-\mathrm{in}$.) elevation difference between the middle and the edge of the pad (Fig. 5.3). The middle of the pad contains a sump $0.30 \times 1.2 \times 0.60 \mathrm{~m}$ $(1 \times 4 \times 2 \mathrm{ft})$. The pad is used for storage of 208- and 114-L (55- and 30-gal) drums of mixed waste. The drums are placed on pallets and double-stacked, and are arranged in rows to provide aisle space for personnel and equipment. The total capacity of the pad is $83,279 \mathrm{~L}$ (22,000 gal), or 400 208-L (55-gal) drums.

Wastes stored at this facility are similar to those stored in Building 7654; they consist of scintillation counting vials containing organic and inorganic mixtures contaminated with low levels of radioactivity. Toluene and xylene are regular constituents of the mixtures. Radionuclides present include ${ }^{3} \mathrm{H},{ }^{14} \mathrm{C},{ }^{32} \mathrm{P}$, and ${ }^{131} \mathrm{I}$. Other waste stored includes organic wastes, carcinogenic wastes, mercury-contaminated solid wastes, waste oils, waste solvents, and other process wastes.

\subsubsection{Building 7823 - mixed waste storage}

Building 7823 , located in Solid Waste Storage Area $5 \mathrm{~N}$, is a $390.6-\mathrm{m}^{2}\left(4200-\mathrm{ft}^{2}\right)$ single-level, semiunderground building with a concrete floor, steel supports, wire fabric ceiling, and metal roof and walls. The facility will hold approximately $1100208-\mathrm{L}$ (55-gal) 


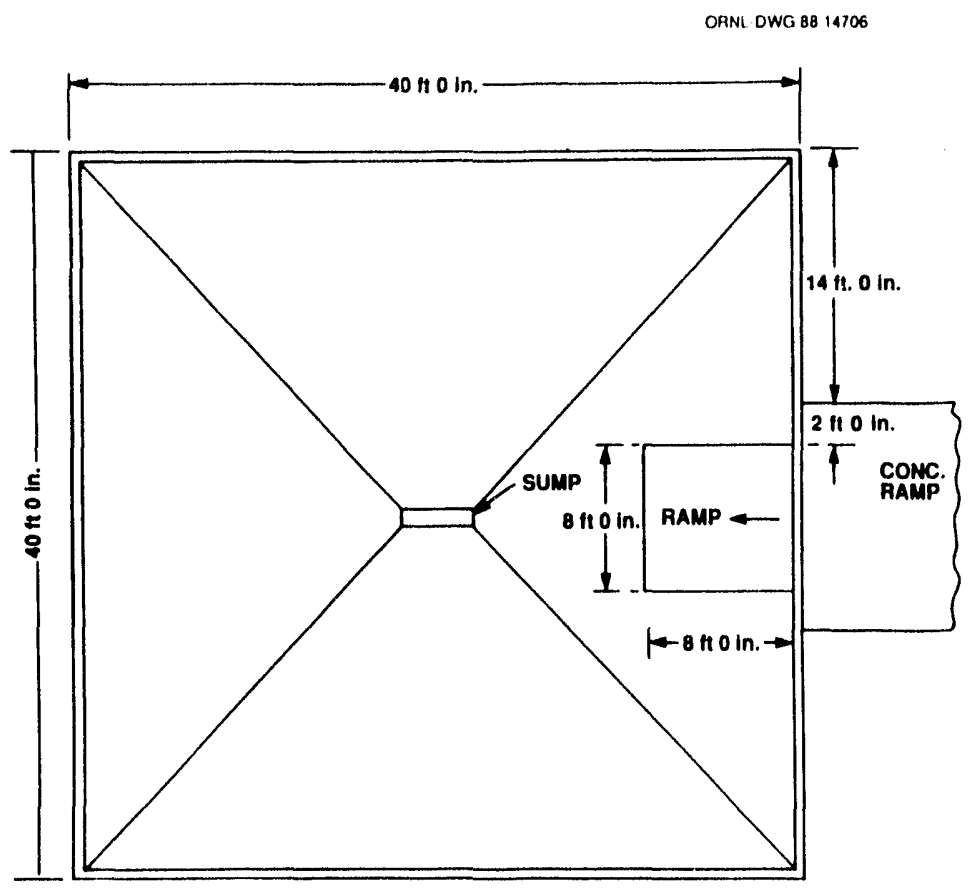

Fig. 5.3. Layout of the Mixed Waste Storage Pad (Building 7507W).

drums. Wastes currently stored in this facility include mixed waste oils, solvents, and other process wastes.

\subsubsection{Tanks 7075 and $7830 a-$ bulk mixed waste oils}

Tanks 7075 and 7830 a provide a total capacity of $34,825 \mathrm{~L}(9200 \mathrm{gal})$ for mixed waste oils. Tank 7830a, located near the New Hydrofracture Facility inside Building 7830a, provides storage for waste oils contaminated with spent solvents, metals, and radiological constituents. The tank has a nominal capacity of $18,927 \mathrm{~L}(5000 \mathrm{gal})$. Tank 7075 , located in the 7000 Area east of the main ORNL Complex, provides storage for waste oils contaminated with radioactive material. This tank currently contains ${ }^{3} \mathrm{H}$ contaminated oil. The tank has a nominal capacity of $15,899 \mathrm{~L}(4200 \mathrm{gal})$. Currently, tank 7075 is undergoing closure. The contents of the tank are expected to be treated at the TSCA Incinerator.

\subsubsection{Environmental monitoring}

The facilities used for mixed we, te storage at ORNL are maintained to prevent contaminant releases to the environment. The curbed dikes and sumps of the facilities are inspected for cracks and leaks; any spill is removed immediately to prevent contamination. Containers are kept closed during storage and handled in a manner to prevent damage and leakage. The bulk storage tanks at ORNL are also inspected and maintained in similar manners according to the requirements outlined in 40 CFR Pt. 265. 


\subsubsection{Permitting status}

Buildings $7654,7507 \mathrm{~W}$, and 7823 and tank $7830 \mathrm{a}$ are currently operating under interim status. Tank 7075 is in the RCRA closure process; completion is expected in CY 1994. Buildings 7823 and 7934 (currently a hazardous waste storage facility) are to be upgraded and permitted for mixed waste storage. Consolidated RCRA Part B permit applications for the two types of RCRA storage facilities (i.e., TRU mixed and non-TRU mixed) were submitted to the Tennessee Department of Environment and Conservation (TDEC) in 1993. A Part B permit application for tank 7830a was submitted to the TDEC in November 1991. The status of the TRU-mixed facilities is discussed in Subsect. 3.1.1. Table 9.1 in Subsect. 9.1 of this plan provides the current operational and permitting status of ORNL treatment, storage, and disposal facilities.

RCRA Sect. 3004(j) prohibits storage of LDR wastes except "solely for the purpose of accumulation of such quantities of hazardous waste as necessary to facilitate proper recovery, treatment, or disposal." Implementing regulations in 40 CFR Pt. 268.50 place the burden of demonstrating noncompliance on the EPA during the first year of waste storage and the burden of demonstrating compliance on the waste generator for waste stored beyond 1 year.

The RCRA LDR FFCA has specified the wastes in storage that do have available treatment (Table 5.2). Those wastes in storage that do not have treatment available are listed in Table 5.3 .

\subsubsection{Facility status}

Mixed waste storage availability at ORNL is severely limited at present; approximately 100 drums are generated on an annual basis. Building $7507 \mathrm{~W}$ has reached capacity in the volume of mixed waste currently stored at the facility, and Building 7654 is also nearing capacity. To relieve this congested condition, interin storage at the Oak Ridge K-25 Site is being pursued. Approximately 300 drums of flammable hazardous waste were shipped to the Oak Ridge K-25 Site in FY 1993.

Two new mixed waste storage facilities are planned at ORNL. The first facility is a 1989 general plant project (GPP) having a total estimated cost (TEC) of $\$ 485 \mathrm{~K}$. The design was completed and certified for construction in May 1991. The project is currently on hold waiting approval of National Environmental Policy Act documentation. The second facility is planned as a $1993 \mathrm{GPP}$ and has an expected TEC of $\$ 1050 \mathrm{~K}$.

An upgrade to Building 7507 is planned as a $1990 \mathrm{GPP}$; the TEC is $\$ 150 \mathrm{~K}$. This upgrade will provide a staging area for contaminated, recyclable lead or hazardous waste; expected operational startup is currently on hold.

\subsubsection{Disposal Facilities}

ORNL has no disposal facilities for mixed waste. As part of its scope, the Energy Systems Waste Management Organization will evaluate the need for a mixed waste disposal facility on the Oak Ridge Reservation. Mixed waste disposal facilities must meet the requirements of all applicable RCRA (or TSCA) and AEA regulations and must be permitted to operate as specified in the regulations. In addition, DOE orders contain specific guidance on the handling of radioactive wastes and on occupational exposure to radioactivity. 
Table 5.2. Oak Ridge National Laboratory land disposal restriction mixed waste with identified existing treatment

\begin{tabular}{|c|c|c|c|c|c|}
\hline $\begin{array}{c}\text { Waste } \\
\text { identification }\end{array}$ & $\begin{array}{l}\text { Primary } \\
\text { constituents }\end{array}$ & $\begin{array}{c}\text { Annual } \\
\text { generation } \\
(\mathrm{kg})^{a}\end{array}$ & $\begin{array}{l}\text { Storage } \\
12 / 31 / 91 \\
(\mathrm{~kg})\end{array}$ & Storage facility ${ }^{b}$ & $\begin{array}{l}\text { Radioactive } \\
\text { categoryc }^{c}\end{array}$ \\
\hline $\begin{array}{l}\text { Commercial } \\
\text { chemicals } \\
\text { (solids and } \\
\text { liquids) }\end{array}$ & $\begin{array}{l}\text { P-listed, } \\
\text { U-listed, } \\
\text { DOMX }\end{array}$ & 2,937 & 3,088 & $e$ & $\mathrm{R}$ \\
\hline Corrosives & D002, DOMX & 1,863 & 3,108 & $e$ & $\mathrm{R}$ \\
\hline Solvents & FOMX & 9,145 & 30,075 & $e$ & $R$ \\
\hline Flammables & D001 & 9,671 & 54,564 & $e$ & $\mathrm{R}$ \\
\hline Oxidizers & D001, DOMX & 1,299 & 1,017 & $e$ & $\mathrm{R}$ \\
\hline $\begin{array}{l}\text { Combustible } \\
\text { (solids and } \\
\text { liquids) }\end{array}$ & DOMX, FOMX & 11,000 & 20,000 & $e$ & $\mathrm{R}$ \\
\hline Poison (PCB) & UOMX & 236 & 236 & $e$ & $\mathrm{R}$ \\
\hline Solvent (PCB) & FOMX & 1,833 & 1,833 & $e$ & $\mathrm{R}$ \\
\hline Flammable (PCB) & D001 & 1 & 1 & $e$ & $\mathrm{R}$ \\
\hline $\begin{array}{l}\text { Combustible liquid } \\
\text { tank } 7830 \mathrm{~A}\end{array}$ & FOMX, DOMX & 6,388 & 6,500 & $7830 \mathrm{~A}$ & $\mathrm{R}$ \\
\hline $\begin{array}{l}\text { Oil-contaminated } \\
\text { solid }\end{array}$ & D018, DOMX & 0 & 1,286 & $\begin{array}{l}7507 \mathrm{~W}, 7654, \mathrm{CH} \text { and } \\
\text { RH TRU units }\end{array}$ & $\mathrm{R}$ \\
\hline Oil & D018, DOMX & 0 & 19,495 & $\begin{array}{l}7507 \mathrm{~W}, 7654, \mathrm{CH} \text { and } \\
\text { RH TRU units, } \\
7830 \mathrm{~A}, 7075\end{array}$ & $\mathrm{R}$ \\
\hline $\begin{array}{l}\text { Combustible } \\
\text { liquid, tanks } \\
7075 \text { and } 7860 \mathrm{~A}\end{array}$ & D018, DOMX & 0 & 13,978 & $7075,7860 \mathrm{~A}$ & $\mathrm{R}$ \\
\hline $\begin{array}{l}\text { LLW System } \\
\text { tanks, liquid }\end{array}$ & $\begin{array}{l}\text { D002, D006, } \\
\text { D007, D008, } \\
\text { D009 }\end{array}$ & 66,300 & $1,500,000$ & $\mathrm{~W} 21-31, \mathrm{C} 1, \mathrm{C} 2^{f}$ & $\mathrm{R}$ \\
\hline
\end{tabular}

${ }^{a}$ Estimated based on 1991 generation.

${ }^{b}$ Storage facility includes proposed units to be built in the future.

" $R$ " indicates waste with known radioactive constituents; an " $S$ " would indicate waste suspected of containing radioactive constituents.

${ }^{d} \mathrm{OMX}$ includes all waste codes for that category (D, P, U, and F).

All-7651, 7652, 7653, 7934, 7654, 7507, 7507W, 7823, 7879, 7855, 7668; new mixed waste, 7883, 7884, 7572, 7574.

These tanks are a part of the CERCLA 120 Federal Facility Agreement that became effective 1/1/92. Schedules are negotiated annually in the FFA.

Source: Adapted from Federal Facilities Compliance Agreement for RCRA LDR Mixed Waste, Appendix A. 
Table 5.3. Oak Ridge National I.aboratory land disposal restriction mixed waste without identified existing treatment

\begin{tabular}{|c|c|c|c|c|c|}
\hline Waste identification & $\begin{array}{c}\text { Primary } \\
\text { constituents }\end{array}$ & $\begin{array}{l}\text { Annual } \\
\text { generation } \\
(\mathrm{kg})^{a}\end{array}$ & $\begin{array}{l}\text { Storage } \\
12 / 31 / 91 \\
(\mathrm{~kg})\end{array}$ & $\begin{array}{l}\text { Storage } \\
\text { facility }^{b}\end{array}$ & $\begin{array}{c}\text { Radioactive } \\
\text { category" }\end{array}$ \\
\hline $\begin{array}{l}\text { EP Tox/TCLP } \\
\text { (solids and } \\
\text { liquids) }\end{array}$ & $\begin{array}{l}\text { DO()4-I)043, } \\
\text { DOMX }\end{array}$ & 11,485 & 25,213 & $e$ & $\mathrm{R}$ \\
\hline $\begin{array}{l}\text { Commercial } \\
\text { chemicals (solids } \\
\text { and liquids) }\end{array}$ & $\begin{array}{l}\text { P-listed, U- } \\
\text { listed, DOMX }\end{array}$ & 9,585 & 10,078 & $e$ & R \\
\hline Corrosives & DOO2, DOMX & 3,725 & 6,217 & $e$ & $\mathrm{R}$ \\
\hline $\begin{array}{l}\text { Reactives and } \\
\text { unknowns } \\
\text { (assumed to be } \\
\text { reactives) }\end{array}$ & DOO3, DOMX & 100 & 157 & $\begin{array}{c}e \\
\text { Except } 7651 \text { or } \\
7507 W\end{array}$ & $\mathrm{R}$ \\
\hline $\begin{array}{l}\text { Photographic } \\
\text { wastes }\end{array}$ & $D(011$ & 16,911 & 11,035 & $e$ & $\mathrm{R}$ \\
\hline $\begin{array}{l}\text { LLLW System } \\
\text { tanks, sludge }\end{array}$ & $\begin{array}{l}\mathrm{DO0} 2, \mathrm{D} 006 \\
\mathrm{D} 007, \mathrm{D} 008, \\
\mathrm{D} 009\end{array}$ & 110,600 & 854,000 & $\begin{array}{l}\text { Active LLW } \\
\text { collection } \\
\text { tanks' }\end{array}$ & $\mathrm{R}$ \\
\hline $\begin{array}{l}\text { Inactive waste } \\
\text { storage tank, } \\
\text { contents }\end{array}$ & $\begin{array}{l}\text { D002, D006, } \\
\text { D007, D008, } \\
\text { D009 }\end{array}$ & 0 & $1,260,000$ & $\begin{array}{l}\text { Inactive waste } \\
\text { storage tanks }\end{array}$ & $\mathrm{R}$ \\
\hline Suspect TRU & FOMX, DOMX & 0 & 191,800 & $\begin{array}{l}\text { CH TRU and } \\
\text { RH TRU units }\end{array}$ & $\mathrm{R}$ \\
\hline
\end{tabular}

"Estimated based on 1991 generation.

"Storage facility includes proposed units to be built in the future.

" $R$ " indicates waste with known radioactive constituents; an " $S$ " would indicate waste suspected of containing radioactive constituents.

"OMX includes all waste codes for that category (D, P, U, and F).

All- 7651, 7652, 7653, 7934, 7654, 7507, 7507W, 7823, 7879, 7855, 7668; new mixed waste, 7883, 7884, 7572, 7574.

these tanks are covered under RCRA permit-by-rule. Wastes are not subject to LDR until removal from the tanks or active tanks are changed to inactive status. These tanks are a part of the ClERCI.A 120 Federal Facilities Agreement effective 1/1/92. Schedules are negotiated annually in the FFA. Not all constituents found in each tank.

Source: Adapted from Federal Facilities Compliance Agreement for RCRA LDR Mixed Waste, Appendix A.

\subsubsection{Status of Support Systems}

\subsubsection{Training}

ORNL training courses are offered for both the generators of radioactive and hazardous wastes. Mixed wastes generators are required to participate in the courses outlined in the training sections of this plan pertaining to both radioactive waste and hazardous waste (Subsects. 3.1.2.6 and 4.1.6.1). 


\subsubsection{Certification}

Detailed procedures for mixed waste management including characterization and certification activities are contained in the ORNL Hazardous Waste Operations Manual. During FY 1993 a formal certification program for ORNL mixed waste was under development. As part of this program, the requirement for generator certification including training will be formalized.

\subsubsection{Database management}

A computerized database is available for tracking all mixed waste, as well as hazardous waste, processed at ORNL. This database is used primarily for record keeping, accounting and billing, and generating annual reports required by the state and the EPA. The database needs to be expanded to provide periodic (e.g., quarterly) reports of waste generation for determining (1) trends in the types and quantities of waste that are being generated and (2) the identity of the generators. In addition to improving facility planning, this information will be useful in monitoring waste minimization efforts. Additional information on this database system is provided in Subsect. 4.1.6.3 of this plan.

\subsubsection{General Plant Projects}

A listing of proposed GPPs for mixed waste facilities at ORNL is provided in Table 5.4. This table indicates the project title, TEC, and the respective fiscal year for funding.

Table 5.4. General plant projects for mixed waste facilities at Oak Ridge National Laboratory

\begin{tabular}{ccc}
\hline Title & $\begin{array}{c}\text { TEC }^{a} \\
(\$ \times 1000)\end{array}$ & $\begin{array}{c}\text { Fiscal } \\
\text { year }\end{array}$ \\
\hline Expand Mixed Waste Storage & 485 & 1989 \\
Mixed Waste Storage Facility & 1100 & 1993 \\
\hline
\end{tabular}

${ }^{a}$ Total estimated cost.

\subsection{GASEOUS WASTE}

There are no facilities or monitoring/sampling devices uniquely designed for mixed gaseous wastes. Management of wastes of this type is performed consistent with radioactive gaseous wastes (Subsect. 3.3.3). 
or

$E$

6

$C$ 


\section{INDUSTRIAL AND SANITARY WASTES}

Industrial waste at Oak Ridge National Laboratory (ORNL) is composed of solid waste generated from Steam Plant operations, coal yard runoff, general refuse, and construction and demolition debris. Sanitary wastewater includes domestic wastewater destined for the Sanitary Wastewater Treatment Plant. Although U.S. Department of Energy (DOE) Order 5820.2A does not specifically require the reporting of industrial waste and sanitary wastewater as part of the annual Waste Management Plan, ORNL has included pertinent information regarding the management of both solid industrial waste and sanitary wastewater at ORNL in the following subsections. The state of Tennessee regulates these waste streams at ORNL via the Tennessee Solid Waste Disposal Act and ORNL's National Pollutant Discharge Elimination System (NPDES) permit from the Clean Water Act (CWA).

\subsection{INDUSTRIAL WASTE}

Industrial wastes are solid wastes that contain no free liquids and at ORNL include filter cake from the Coal Yard Runoff Treatment System, bottom ash from the fireside of the Steam Plant boilers, fly ash from the Steam Plant electrostatic precipitators, general refuse collected in trash cans and dumpsters, and construction and demolition debris. A brief description of each industrial waste stream is provided in Subsect. 6.1.2.

\subsubsection{Strategy}

The strategy for industrial waste disposal at ORNL (illustrated in Fig. 6.1) involves the use of commercial recycle markets and the existing industrial waste landfill (SLF II) at the Oak Ridge Y-12 Plant until filled. The estimated fill date is early 1994. Beginning in 1994, construction will have been completed on a new industrial waste landfill and a new construction/demolition debris landfill. The Anderson County Chestnut Ridge Landfill will still be used for organic wastes such as cafeteria wastes. Because landfill disposal costs continue to increase, commercial recycle markets will continue to be used when appropriate to assist in waste reduction.

\subsubsection{Types of Industrial Wastes at Oak Ridge National Laboratory}

Pollution resulting from acidified runoff from the ORNL Coal Yard Storage Area consists of iron and trace amounts of other metals. Bottom ash from the fireside of boilers is essentially inert material. Fly ash from electrostatic precipitators contains a lighter component of bottom ash. Examples of general refuse at ORNL consists of plastic; rubber; paper; cardboard; wood; brush textiles; heating, ventilating, and air-conditioning filters; and noninfectious medical wastes that are autoclaved and properly packaged.

Construction/demolition debris is composed of clean soil, gravel, rock, concrete, asphalt, asbestos, and roofing materials. 
OANL.DWQ $91 \mathrm{M} \cdot 14983$ P3

\begin{tabular}{|c|c|c|c|c|c|c|c|c|c|c|c|}
\hline \multirow[b]{2}{*}{ WASTE CATEGOAY } & \multicolumn{11}{|c|}{ CALENDAR YEAA } \\
\hline & 1993 & 1994 & 1995 & 1996 & 1997 & 1998 & 1999 & 2000 & 2001 & 2002 & 2003 \\
\hline CLASS II, SOLID INDUSTAIAL WASTES (1) & $\begin{array}{l}Y .12 \\
\text { SLFE }\end{array}$ & & $Y .12$ & LEV & & & & & & & \\
\hline CLASS II, SPECIAL WASTES (2) & $\begin{array}{l}\text { Y.12 } \\
\text { SLEIL }\end{array}$ & & Y.12 & LFV & & & & & & & \\
\hline CLASS IV, CONSTAUCTION SPOIL (3) & $\begin{array}{l}\bar{Y} \cdot 12 \\
\text { SLE }\end{array}$ & coNs & $\begin{array}{r}Y \cdot 12 \\
\text { Buccill }\end{array}$ & $\begin{array}{l}\text { LF VI } \\
\text { NIDEME }\end{array}$ & LIIION & & & & & & \\
\hline \multirow{2}{*}{$\begin{array}{l}\text { RECYCLABLE MATERIALS (4) } \\
\text { OROANIC WASTES }\end{array}$} & & AEC & YCLECC & MMEAC & AlLY & & & & & & \\
\hline & & CHE & INUTA & DQELA & DFILL & & & & & & \\
\hline \multicolumn{12}{|c|}{ 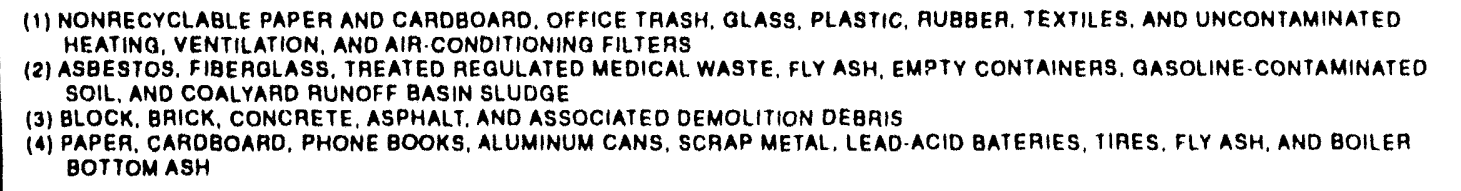 } \\
\hline \multicolumn{12}{|c|}{ DENOTES PLANNED TREATMENT, STORAGE, AND DISPOSAL } \\
\hline \multicolumn{12}{|c|}{ - DENOTES PERIODS OF TRANSITION ANOIOR UNCERTAINTY } \\
\hline
\end{tabular}

Fig. 6.1. Strategy for Oak Ridge National Laboratory industrial waste.

\subsubsection{Industrial Waste Treatment and Storage at Oak Ridge National Laboratory}

The industrial waste streams described below constitute solid industrial waste at ORNL. Upon generation, efforts are taken to allow for the segregation of these waste streams such that free liquids are removed prior to subsequent disposal.

Acidified runoff from the ORNL. Coal Yard Storage Area, plus additional wastewater from the sulfuric acid tank diked area runoff, Steam Plant boiler blowdown, and water softener regenerate is collected in a clay-lined pond. Acidic wastewater is pumped from the pond to a neutralization tank (Fig. 6.2) where a lime slurry adjusts the $\mathrm{pH}$ and precipitates out heavy metals. A polymer is added upstream from the flocculation tank to aid in coagulation in the clarifier. The precipitated solids are removed from the bottom of the clarifier and are dewatered in a vacuum filter using diatomaceous earth as a filter aid. The resulting $264 \mathrm{t}$ year (290 tons/year) of filter cake, determined by the Tennessee Department of Environment and Conservation (TDEC) to be a special waste, is disposed of at the Y-12 SLF. The supernatant from the clarifier, which is not considered an industrial waste or a sanitary waste, flows by gravity to the lower holding pond and into White Oak Creek (WOC) via an overflow wier.

About 25,480 t/year (28,000 tons/year) of coal containing about $8 \%$ ash is burned for steam generation at the ORNL. Steam Plant. Bottom ash from the fire side of the boilers and fly ash from the electrostatic precipitators are pneumatically conveyed to the storage silo. The accumulation of this ash, $\sim 9.2 \mathrm{~m}^{3} / \mathrm{d}\left(\sim 12 \mathrm{yd}^{3} / \mathrm{d}\right)$, is loaded from the silo into dump trucks and transported to an outside vendor, whose operations are being approved for long-term contractual obligations. The Anderson County Chestnut Ridge Landfill and Y-12 SLF are still used as viable options for alternate disposal.

General refuse is collected at each ORNL building from trash cans and placed in dumpsters. These dumpsters are either transported by truck directly to the Y-12 SLF II for 


\section{$6-5$}

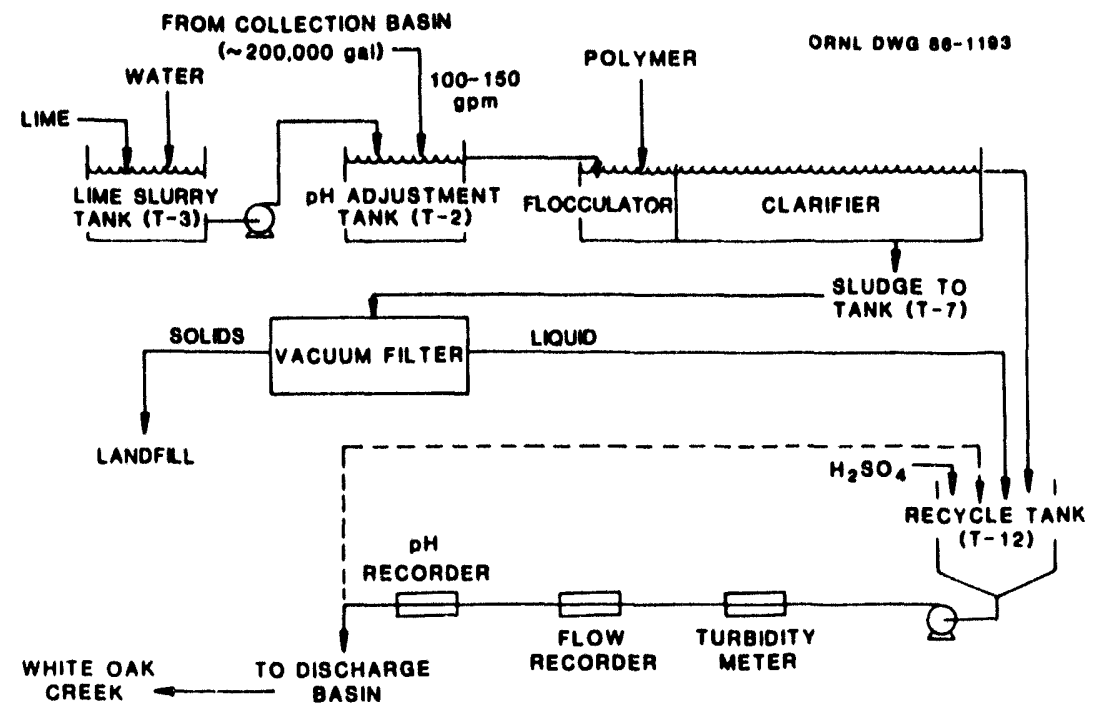

Fig. 6.2. Flow diagram of the Coal Yard Runoff Treatment Facility.

disposal (Fig. 6.3) or accumulated at an on-site trash compactor prior to transport to the Y-12 SLF II. Other than the equipment used for on-site collection, compaction, and transportation of general refuse to the Y-12 SLF II, no treatment or storage facilities currently exist at ORNL for their handling. The volume of general refuse is estimated to be $28.2 \mathrm{~m}^{3}\left(37 \mathrm{yd}^{3}\right)$ per normal work day.

Varying amounts of industrial wastes are also generated from on-going construction and demolition projects at ORNL. Other than the equipment used for on-site collection and transportation of these wastes to the Y-12 SLF II, no treatment or storage facilities currently exist at ORNL for their handling. The nonbiodegradable fraction (i.e., clean soil, gravel, and rock) is being temporarily deposited in a spoil area at the west end of Y-12 SLF II. All other construction/demolition materials including concrete, asphalt, and asbestos are disposed of at the Y-12 SLF II.

Temporary storage facilities for waste scrap metal and waste wood exist on-site at ORNL. Waste wood is destroyed by burning it on-site at ORNL under the controlled burning permit.

\subsubsection{Existing and Future Disposal Facilities}

The Y-12 SLF II (Fig. 6.3) is located on Chestnut Ridge, south of the Oak Ridge Y-12 Plant. It is the primary industrial waste disposal site for the three facilities on the Oak Ridge Reservation. General refuse, which is part of the industrial waste mix and special waste, will continue to be deposited here until filled, which is expected to be early 1994.

Beginning in 1994, or whenever the SLF II is full, industrial and special wastes will be transported to the new TDEC-approved (Class II) Y-12 Industrial Landfill V (Fig. 6.3). Also, construction and demolition debris will be transported to the new TDEC-approved (Class IV) Y-12 Construction/Demolition Landfill VI (Fig. 6.3). 
ORNL.DWO 93M- 15180

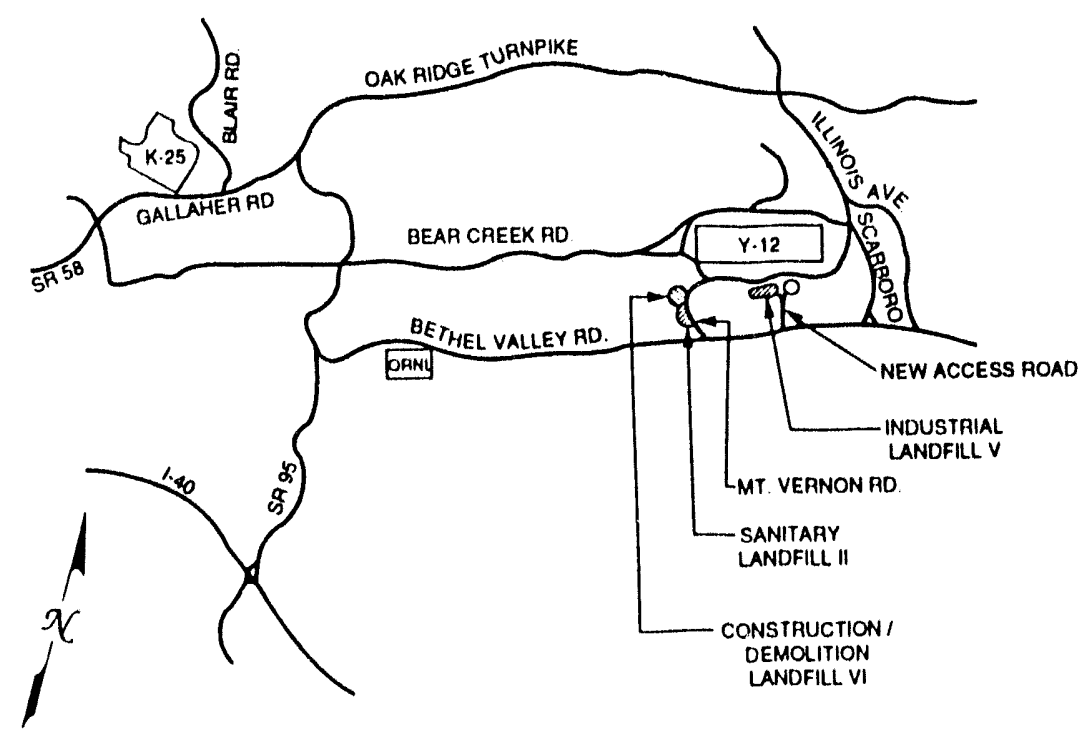

Fig. 6.3. Proposed and existing landfill locations at the Oak Ridge Y-12 Plant.

\subsubsection{Environmental monitoring}

Groundwater monitoring is conducted at the Y-12 SLF II by the Oak Ridge Y-12 Plant monitoring staff. Three groundwater-monitoring wells, one upgradient and two downgradient, have been installed at the site. The groundwater-sampling parameters have been established by the TDEC Division of Solid Waste Management by Regulation 1200-1-7-04(7) groundwater protection/monitoring standards. This regulation will also apply to the operation of the new landfills.

\subsubsection{Permitting status}

The state of Tennessee regulates the operation of industrial waste landfills in accordance with the Tennessee Solid Waste Disposal Act, as amended, and Rules Governing Solid Waste Processing and Disposal in Tennessee. The two state-permitted facilities that have received industrial solid waste from ORNL are the Y-12 SLF II, which was permitted on December 20, 1982, and the ORNL Contractor Landfill, which was permitted on January 23,1986 , and is currently closed. The existing permit for SLF II requires that no liquids, industrial special waste, or waste requiring special handling shall be accepted at the facility unless prior written approval for each individual waste is obtained. As required by the Tennessee Hazardous Waste Act, no hazardous waste shall be accepted at SLF II.

In addition to these general requirements, the SLF II permit establishes minimum daily and weekly cover requirements. The permit also states that only waste specified in the site operations manual as acceptable for disposal shall be deposited unless prior written approval for each individual waste is obtained. Radioactive waste is specifically excluded from disposal. The permit allows disposal of special waste including asbestos, fly ash, and coal yard runoff sludge. The SLF II is projected to be filled to permitted capacity by March 
1994. The exact fill date is dependent on the generation rate of industrial and construction/demolition waste and the success of recycling programs that are being instituted.

\subsubsection{Facility status}

Present strategy at the Oak Ridge Y-12 Plant is to extend the life of the SLF II, which is projected to reach capacity in early 1994, by utilizing alternative disposal methods for selected industrial wastes. A new (Class II) industrial landfill is being constructed at the Oak Ridge Y-12 Plant to provide for the continued disposal of solid industrial waste. This new Industrial Landfill V is being constructed as part of an FY 1990 line item (LI) project. The current projection for placing the landfill in service is March 1994. This landfill will be designed with lined trenches and a leachate collection system in response to increased requirements in the proposed Tennessee Solid Waste Regulations. Also, construction is being completed on a Construction/Demolition Landfill VI. It is expected to be operational by early 1994. This TDEC (Class IV) landfill will be used for the disposal of concrete, rock, asphalt, dirt, glass, wood, and tin.

\subsubsection{Status of Support Systems}

\subsubsection{Training}

Training that addresses the significant aspects : for those ORNL wastes destined for the Y-12 SLF II ing industrial waste disposal rovided by Waste Management to all ORNL employees. This training $W_{l_{2}}$ ue, through the updating of an informational flyer, semiannually until subsequent training is incorporated into the General Employee Training Program. Optional training will include the showing of a Waste Management-prepared video supplemented with the updated informational flyer and will be available for use by all offices and divisions. In addition, waste minimization training and other waste management personnel training is provided to employees involved in waste operations at ORNL (Subsect. 4.1.6).

\subsubsection{Industrial waste control}

The Y-12 SLF II is operated by Y-12 personnel and serves the industrial waste disposal needs of ORNL, the Oak Ridge K-25 Site, and the Oak Ridge Y-12 Plant. The Y-12 SLF II is permitted for operation by the TDEC for disposal of industrial wastes, wastes explicitly listed in the approved operating plan, and special wastes as approved by the TDEC.

The ORNL "Industrial Waste Control Procedure" was developed to implement administrative and physical controls to provide a reasonable level of assurance to the $\mathrm{Y}-12$ SLF II operator that prohibited wastes, as described in the operating permit, are not constituents of the wastes sent to the Y-12 SiF II for disposal. This procedure specifically identifies responsibilities, procedures, and verification techniques to be utilized by ORNL pe. sonnel that will provide a reasonable level of assurance that prohibited materials do not enter the Y-12 SLF II. Exclusion of radioactive and hazardous materials is the primary concern. A certification program is not used and is not the intent of industrial waste control at ORNL. 


\subsubsection{Database management}

The Asbestos Tracking System provides data on ORNL's removal (via building demolition or renovation) and disposal of asbestos. Information collected includes volume, weight, waste origin (i.e., demolition or renovation), waste type (i.e., friable or transite), date of removal, radioactive contamination, and final disposition. The Asbestos Tracking Database Management System will be operated by the Waste Management Operations Group and will begin operations during the first half of 1994. The system will generate quarterly summary reports on asbestos activities and compile yearly disposal totals for other hazardous waste reports. At present, removal and disposal of clean asbestos is the responsibility of Plant and Equipment Division's Asbestos Management Group. Asbestos contaminated with radioactivity or hazardous wastes will be handled by the Hazardous Waste Operations Group. Also, a database management system, developed and operated by Y-12 staff, relates total volume and weight of industrial solid waste disposed by ORNL generators for each month into the Y-12 SLF II. In 1994 this database manayement system will record industrial waste from dumpsters and other containers from ORNL into the new Waste Tracking Project under an existing blanket UCN-2109.

\subsubsection{General Plant Projects}

No general plant projects (GPPs) are planned for industrial solid wastes by ORNL. But, through Y-12 funding beginning in 1994, or whenever the SLF II is full, industrial and special wastes will be transported to the newly constructed, TDEC-approved (Class II) Industrial Landfill V (Fig. 6.3). Also, construction and demolition debris will be transported to the newly constructed, TDEC-approved (Class IV) Construction/Demolition Landfill VI (Fig. 6.3).

\subsubsection{Recycling Activities}

Figure 6.4 shows quarterly, yearly, and cumulative tonnages of corrugated boxboard recycled at ORNL (beginning in the second quarter of 1991 and continuing through the third quarter of 1993). In August of 1993 (third quarter), baling of cardboard for recycling was replaced with a less labor intensive recycling process. Cardboard is now compacted into a $306-\mathrm{m}^{3}\left(40-\mathrm{yd}^{3}\right)$ dumpster and hauled to a local paper-recycling company. Similar graphs are shown for quantities of white paper, aluminum cans, phone books, and toner cartridges recycled at ORNL in Figs. 6.5, 6.6, 6.7, and 6.8 respectively.

\subsection{SANITARY WASTE}

Sanitary/domestic waste streams include all waste streams that are discharged to WOC via the Bethel Valley Wastewater Treatment Plant. This includes all ORNL septic tank or holding tank locations that require pump and haul prior to treatment. 
ORNL-DWG 93M-15165

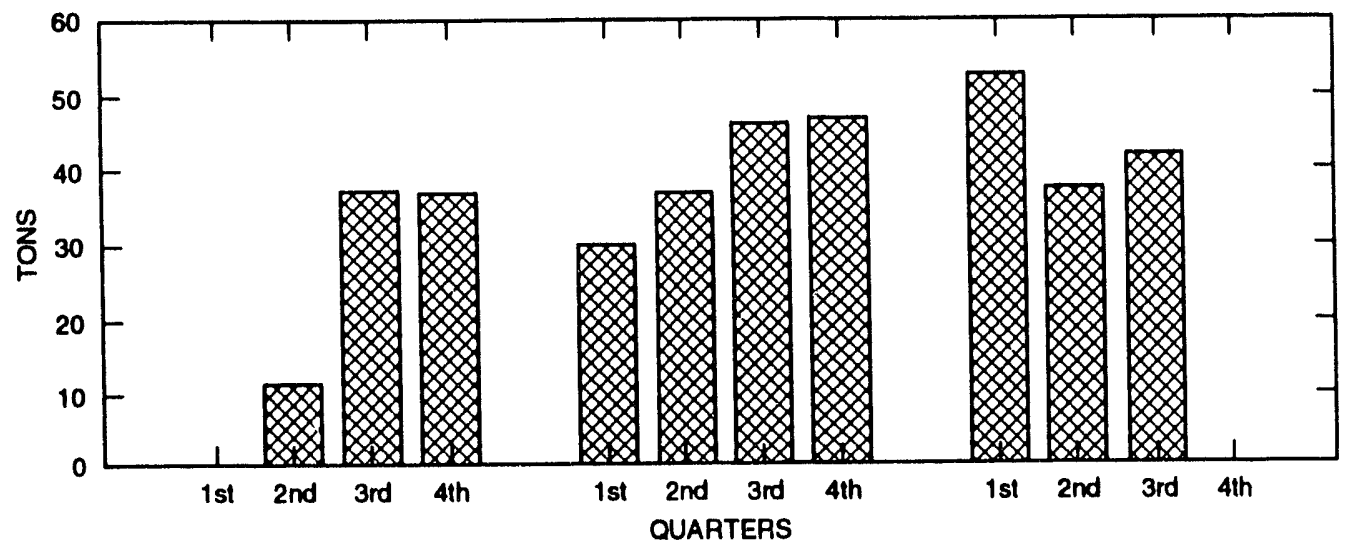

\begin{tabular}{|c|c|c|c|c|c|c|c|c|c|c|c|c|}
\hline & \multicolumn{4}{|c|}{$1991^{\circ}$} & \multicolumn{4}{|c|}{$1992^{\circ}$} & \multicolumn{4}{|c|}{$1993^{\circ}$} \\
\hline & $1 \mathrm{st}$ & 2nd & 3rd & 4th & $1 s t$ & 2nd & 3rd & 4th & $1 s t$ & 2nd & 3rd & 4th \\
\hline QUARTERLY TOTAL & 0.0 & 11.3 & 36.8 & 36.4 & 29.4 & 36.0 & 45.3 & 45.6 & 51.8 & 35.8 & 40.2 & \\
\hline YEARLY TOTAL & 0.0 & 11.3 & 48.1 & $84^{\circ}$ & 29.4 & 65.4 & 110.7 & 156.4 & 51.8 & 87.6 & 127.8 & \\
\hline CUMULATIVE TOTAL & 0.0 & 11.3 & 48.1 & $\overline{8} 4.5$ & 114.0 & 150.0 & 195.3 & 240.9 & 292.7 & 328.5 & 368.7 & \\
\hline
\end{tabular}

-AMOUNTS IN TONS

Fig. 6.4. Quarterly, yearly, and cumulative values in tons for corrugated boxboard recycled at Oak Ridge National Laboratory during 1991, 1992, and 1993.

ORNL-DWG 93M-15167

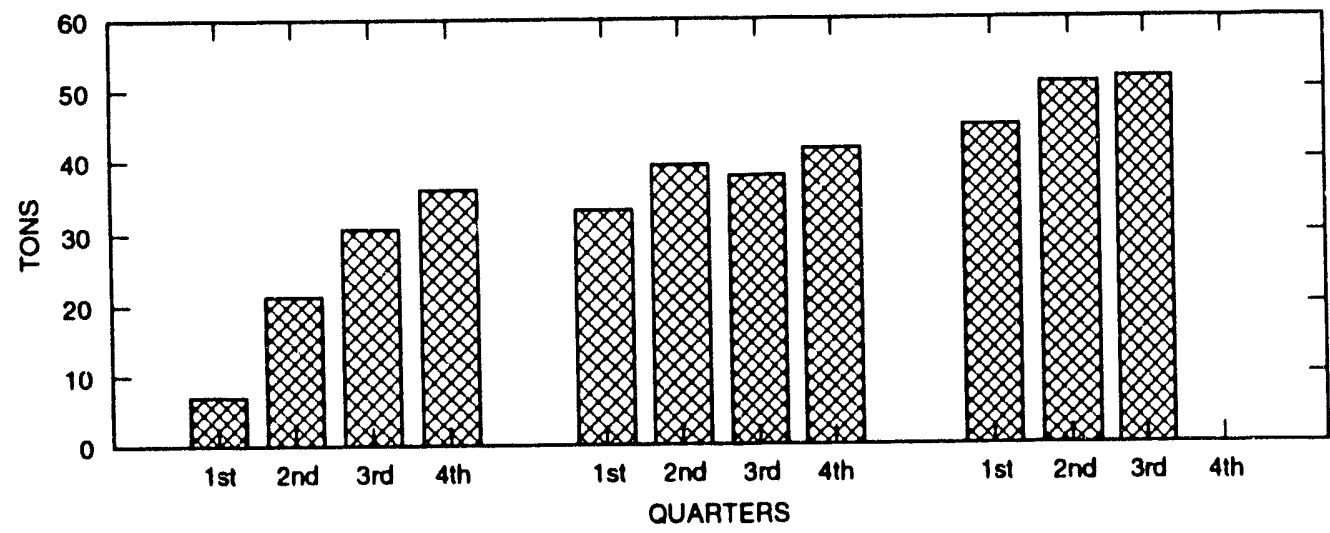

\begin{tabular}{|c|c|c|c|c|c|c|c|c|c|c|c|c|}
\hline & \multicolumn{4}{|c|}{$1991^{\circ}$} & \multicolumn{4}{|c|}{$1992^{\circ}$} & \multicolumn{4}{|c|}{$1993^{\circ}$} \\
\hline & $1 \$$ & 2nd & 3 rd & 4th & $19 t$ & 2nd & 3 d & $4 \mathrm{~h}$ & 1 st & 2nd & $3 r d$ & 4th \\
\hline OUARTERLY TOTAL & 7.1 & 21.3 & 30.8 & 36.2 & 33.5 & 39.6 & 38.0 & 42.0 & 45.1 & 51.2 & 52.0 & \\
\hline YEARLY TOTAL & 7.1 & 28.4 & 59.2 & 95.4 & 33.5 & 73.1 & 111.1 & 153.1 & 45.1 & 96.3 & 148.3 & \\
\hline CUMULATIVE TOTAL & 7.1 & 28.4 & 59.2 & 95.4 & 128.8 & 168.4 & 206.4 & 248.4 & 293.5 & 344.7 & 396.8 & \\
\hline
\end{tabular}

-AMOUNTS IN TONS

Fig. 6.5. Quarterly, yearly, and cumulative values in tons for white paper recycled at Oak Ridge National Laboratory during 1991, 1992, and 1993. 
ORNL.DWG 93M-15166

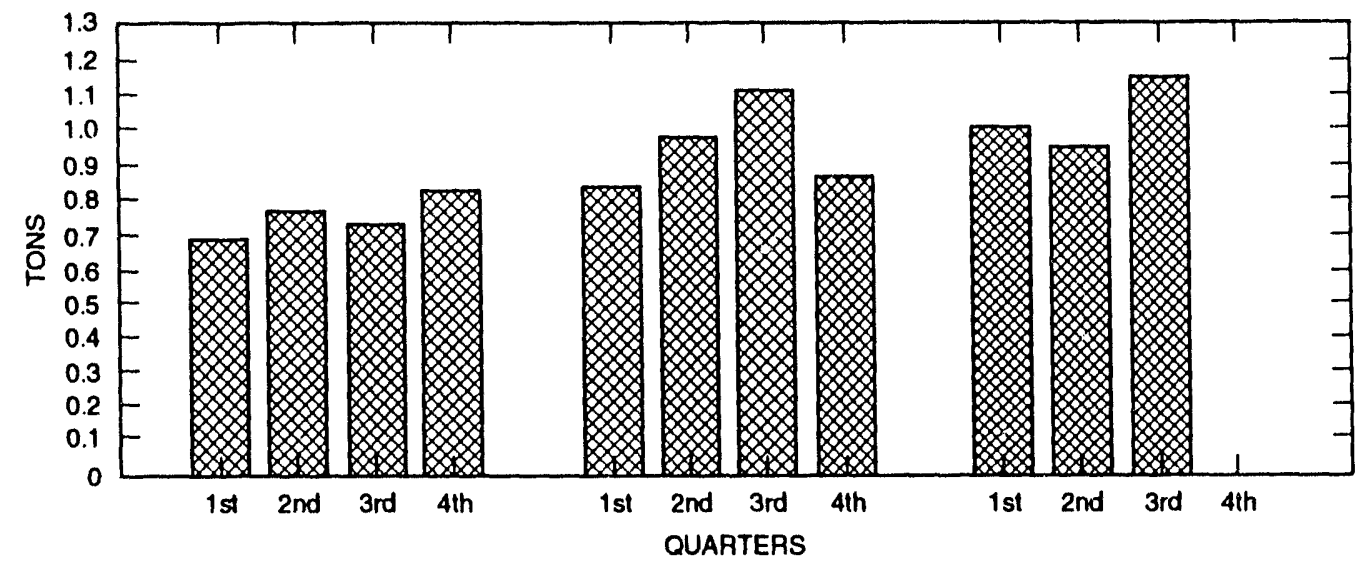

\begin{tabular}{|c|c|c|c|c|c|c|c|c|c|c|c|c|}
\hline & \multicolumn{4}{|c|}{ 1991" } & \multicolumn{4}{|c|}{$1992^{*}$} & \multicolumn{4}{|c|}{$1993^{\circ}$} \\
\hline & 1st & 2nd & 3 d & 4th & 1st & 2nd & 3 rd & 4th & $1 \mathrm{st}$ & 2nd & 3 rd & 4th \\
\hline OUARTERLY TOTAL & 0.7 & $n 2$ & 0.7 & 0.8 & 0.8 & 1.0 & 1.1 & 0.9 & 1.0 & 1.0 & 1.2 & \\
\hline YEARLY TOTAL & 0.7 & $\overline{1.5}$ & 2.2 & 3.1 & 0.8 & 1.8 & 3.0 & 3.8 & 1.0 & 2.0 & 3.2 & \\
\hline CUMULATIVE TOTAL & 0.7 & 1.5 & 2.2 & 3.1 & 3.9 & 4.9 & 6.0 & 6.9 & 7.9 & 8.9 & 10.1 & \\
\hline
\end{tabular}

-AMOUNTS IN TONS

Fig. 6.6. Quarterly, yearly, and cumulative values in tons for aluminum cans recycled at Oak Ridge National Laboratory during 1991, 1992, and 1993.

OANL-DWG 93M.15163

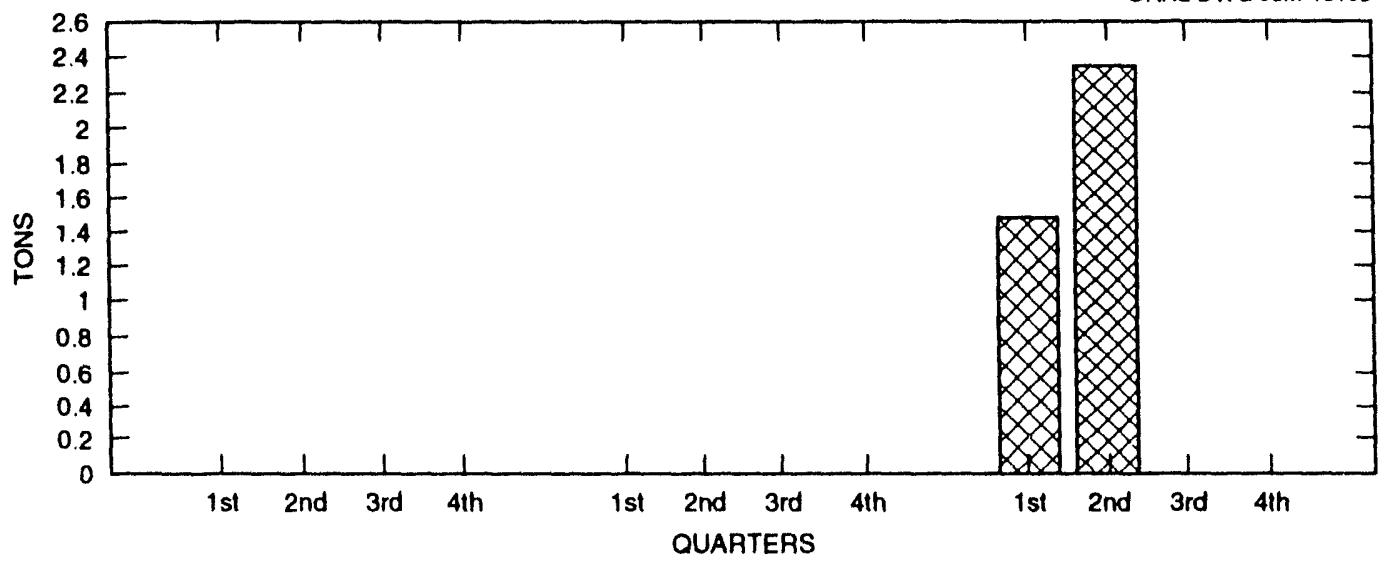

\begin{tabular}{|c|c|c|c|c|c|c|c|c|c|c|c|c|}
\hline & \multicolumn{4}{|c|}{$1991^{\circ}$} & \multicolumn{4}{|c|}{$1992^{*}$} & \multicolumn{4}{|c|}{$1993^{\circ}$} \\
\hline & 1st & 2nd & 3rd & 4th & 1 st & 2nd & 3 d & 4th & $15 t$ & 2nd & 3 d & 4th \\
\hline QUARTERLY TOTAL & 0.0 & 0.0 & 0.0 & 0.0 & 0.0 & 0.0 & 0.0 & 0.0 & 1.5 & 2.4 & & \\
\hline YEARLY TOTAL & 0.0 & 0.0 & 0.0 & 0.0 & 0.0 & 0.0 & 0.0 & 0.0 & 1.5 & 3.9 & & \\
\hline CUMULATIVE TOTAL & 0.0 & 0.0 & 0.0 & 0.0 & 0.0 & 0.0 & 0.0 & 0.0 & 1.5 & 3.9 & & \\
\hline
\end{tabular}
•AMOUNT IN TONS

Fig. 6.7. Quarterly, yearly, and cumulative values in tons for phone books recycled at Oak Ridge National Laboratory during 1991, 1992, and 1993. 
ORNL-DWG 93M-15164

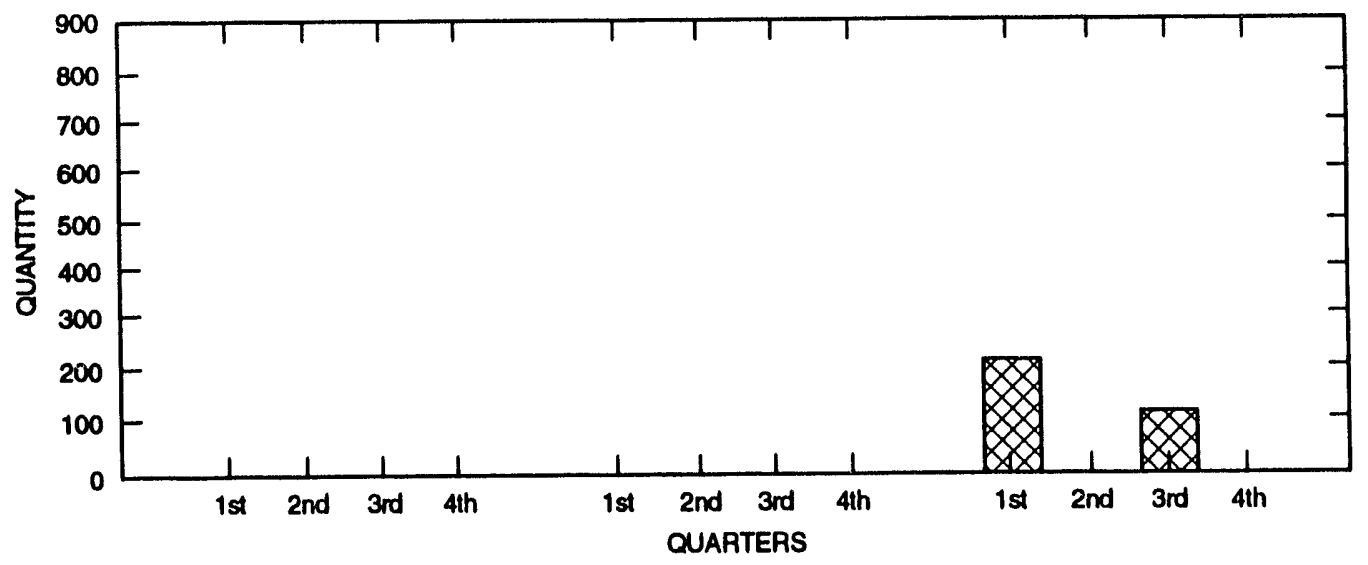

\begin{tabular}{|c|c|c|c|c|c|c|c|c|c|c|c|c|}
\hline & \multicolumn{4}{|c|}{1991} & \multicolumn{4}{|c|}{1992} & \multicolumn{4}{|c|}{1993} \\
\hline & $1 s t$ & 2nd & 3 rd & 4th & $15 t$ & 2nd & 3rd & 4hth & 1st & 2nd & 3rd & 4th \\
\hline QUARTERLY TOTAL & 0 & 0 & 0 & 0 & 0 & 0 & 0 & 0 & 223 & 0 & 129 & 0 \\
\hline YEARLY TOTAL & 0 & 0 & 0 & 0 & 0 & 0 & 0 & 0 & 223 & 223 & 352 & 352 \\
\hline CUM ULATIVE TOTAL & 0 & 0 & 0 & 0 & 0 & 0 & 0 & 0 & 223 & 223 & 352 & 352 \\
\hline
\end{tabular}

Fig. 6.8. Quarterly, yearly, and cumulative numerical totals for toner cartridges recycled at Oak Ridge National Laboratory during 1991, 1992, and 1993.

\subsubsection{Strategy}

The management strategy for sanitary waste at ORNL must comply with the U.S. Environmental Protection Agency (EPA), CWA, TDEC regulations, and DOE orders. Some programmatic strategies that exist at ORNL include sampling and analysis of various wastewater sources prior to discharge to the Sanitary Wastewater Treatment Plant, effluent sampling and analysis of sanitary wastewater prior to discharge to receiving streams per NPDES regulations, examination of the toxic effects of sanitary wastewater on the receiving stream, reduction of hydraulic loading by eliminating groundwater infiltration, and aggressive pursuit of environmental pro .... that will keep discharge concentrations below NPDES permit levels.

\subsubsection{Characteristics of Sanitary Wastewater}

The average daily flow of domestic wastewater at the ORNL Sanitary Wastewater Treatment Plant is $946,353 \mathrm{~L} / \mathrm{d}(250,000 \mathrm{gal} / \mathrm{d})$ (Fig. 6.9). This includes all sanitary wastewater from the Bethel and Melton Valley facilities, which serves a population of approximately 5000 people. Sanitary wastewater is collected and treated separately from other wastewaters. After treatment, the effluent is sampled and analyzed for settleable solids, suspended solids, floating solids, biochemical oxygen demand, ammonia-nitrogen, metals, organics, fecal coliform, and free chlorine residuals. If the effluent meets the designated NPDES permit conditions, it will be discharged to WOC. Chlorine is used as a disinfectant prior to discharge to the receiving stream. At present, thickened sludge is removed from the 
ORNL DWG 85-932R

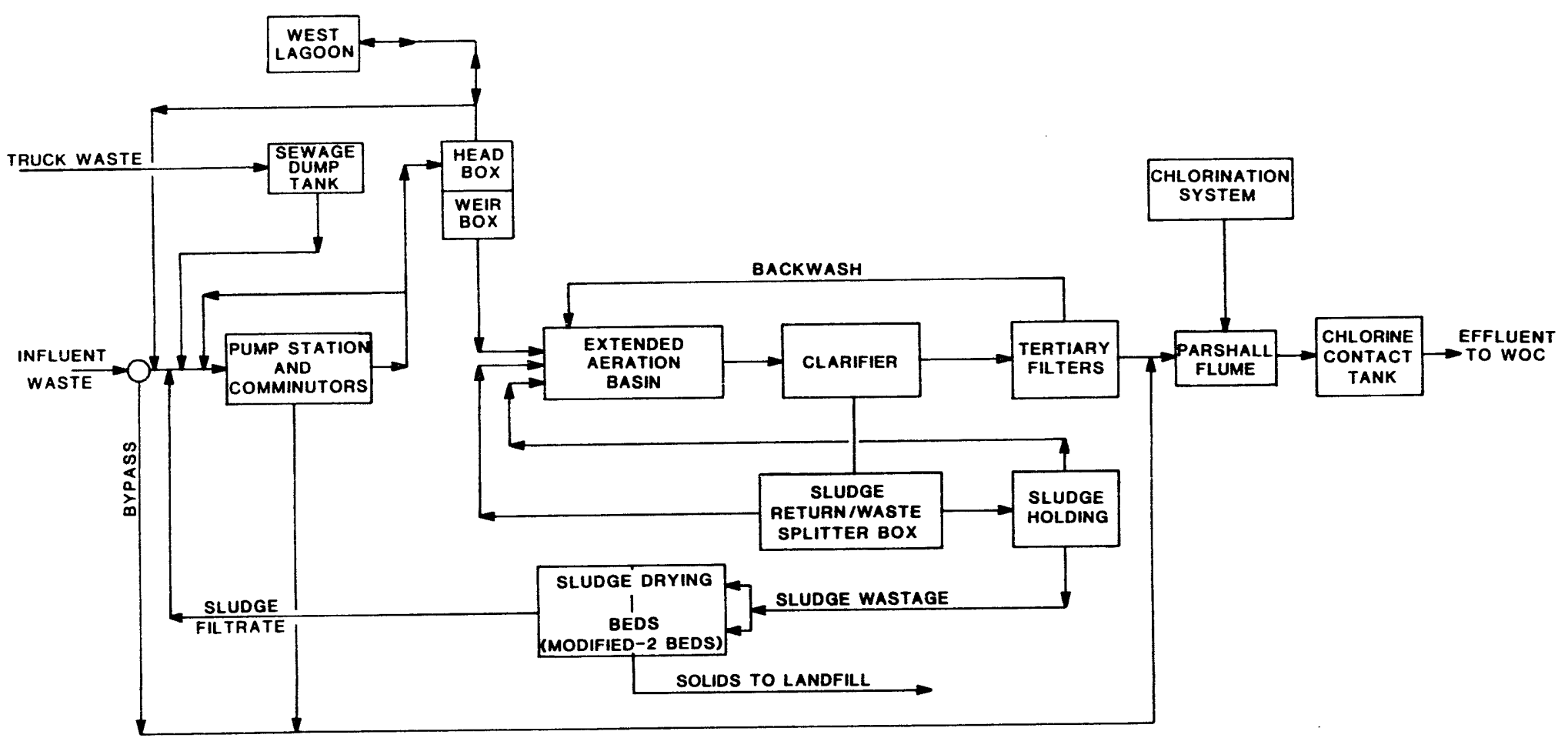

Fig. 6.9. Block flow diagram for the Sewage Treatment Plant. WOC-White Oak Creek. 
drying beds and hauled to Solid Waste Storage Area (SWSA) 6 silos for storage. The TDEC is expected to shut down this method of sludge storage sometime during the first part of 1994. New methods of sanitary waste sludge handling being investigated by ORNL include land disposal in conjunction with the city of Oak Ridge sanitary waste sludge, filling of B-25 boxes with sludge from sludge-drying beds prior to tumulus storage, incineration at Scientific Ecology Group, and contracting with outside vendors for volume reduction. Other wastewaters that contain slight amounts of radioactive or hazardous materials or may be periodically contaminated are considered to be process wastes and are discussed in Subsect. 3.2.3.

\subsubsection{Sanitary Wastewater Treatment Facility}

The Sanitary Wastewater Treatment Facility (Fig. 6.9), located in Building 2521 near the ORNL Steam Plant, employs an extended aeration activated sludge treatment system followed by mixed media filtration of secondary effluent and on-site sludge-drying in open air sludge-drying beds. This extended aeration system was designed to handle a hydraulic loard of $1,135,624-\mathrm{L} / \mathrm{d}(300,000 \mathrm{gal} / \mathrm{d})$ and to remove $95 \%$ of the biochemical oxygen demand and suspended solids as primary and secondary treatment.

Sanitary wastewater from the facility flows by gravity into a large wetwell. Lift pumps are used to transport the wastewater to the influent header box where the wastewater flows by gravity into the extended aeration mixed liquor basin. Following the 30 -h extended aeration period, the mixed liquor flows by gravity to the clarifier. Here, the supernatant from the clarifier overflows the sawtooth wier and flows by gravity to the mixed bed filtration media for tertiary treatment. The solids settle to the bottom of the clarifier and, depending on operational requirements, are returned to the extended aeration system to aid in the digestion process or are pumped to the aerobic digester for sludge thickening. Thickened sludge flows by gravity to the sludge-drying beds and when dry is transported by truck to SWSA 6 silos for storage. Supernatant from the mixed bed filter media is chlorinated in a chlorine contact chamber and discharged through a Parshall flume to WOC. Accumulated sludge from the mixed bed filter media is backwashed and returned to the extended aeration mixed liquor tanks or the waste lagoon. The waste lagoon is an old oxidation pond that has been converted into a surge basin to collect wastewater overflow. The mixed media tertiary filtration system was introduced at a later date to provide additional treatment that would satisfy more stringent regulatory requirements.

\subsubsection{Environmental monitoring}

Environmental monitoring at ORNL includes surveillance of surface water and groundwater quality. Implementation of this effort involves finding the appropriate location, operating reliable sensor devices, employing facilities and their equipment for receipt and presentation of data, and applying confident modeling and predictive capability.

Water and biological monitoring activities at ORNL are defined by the respective NPDES permit and by DOE guidelines for environmental monitoring and surveillance around nuclear facilities. In response to DOE guidelines for environmental monitoring, flow and analytical data are collected to determine conditions of nonradiological constituents from ORNL processes. Under the current NPDES permit, over 150 monitoring stations and point sources are monitored at their point of discharge into receiving streams. The Biological Monitoring Program includes the collection of fish, milk, soil, and grass for investigation of pollutant movement within the food chain. 


\subsubsection{Permitting status}

Facilities for waste treatment must be available for both current and future disposal activities. Environmental risks, as well as risks to the health and safety of the public, will be minimized by ensuring that all discharges from ORNL sources comply with the requirements of all applicable environmental regulations.

Current regulatory requirements for ORNL include the CWA, the Safe Drinking Water Act, and DOE orders. At present, the water and biological monitoring activities are in compliance with applicable regulatory requirements. However, this situation could change should any or all of the following conditions develop: (1) authority to regulate radiological discharges is granted to the EPA and the state of Tennessee, (2) guidelines for environmental surveillance are changed by DOE, or (3) authority to monitor surface waters from solid waste management units at ORNL is determined to lie within Resource Conservation and Recovery Act provisions. Consequently, the strategy for water and biological monitoring is to evaluate potential regulatory changes or new regulations to determine whether additional capabilities or new equipment will be required for future compliance.

The original ORNL NPDES permit, which became effective April 1, 1986, authorized ORNL to discharge to the Clinch River, WOC, the Northwest Tributary, Melton Branch, Fifth Creek, First Creek, and Bearden Creek Embayment of Melton Hill Lake in accordance with meeting effluent limitations, monitoring requirements, and other conditions set forth in the permit. The original permit expired in April 1991. It is currently being renegotiated, which may involve some degree of facility upgrading to meet new discharge requirements. ORNL also observes and complies with the Federal Facilities Compliance Agreement that sets forth plans and dates for the elimination of untreated discharges and construction of treatment facilities.

\subsubsection{Facility status}

Bench-scale studies have been conducted to determine if the Coal Yard Runoff Treatment Facility (CYRTF) should use magnesium hydroxide as a filter aid instead of lime, which is now being used. These studies have indicated that magnesium hydroxide has less toxic effects on the effluent discharged to the receiving stream. To implement this change in process operations, it has been necessary to acquire permission from the TDEC before disposing of solids to the Y-12 SLF. Approval from NPDES regulators to discharge effluent with magnesium rather than calcium to the receiving stream has already been accepted.

Also, the CYRTF has received permission from the TDEC to treat boiler blowdown and ion exchange regenerate solutions from the Steam Plant and discharge along with other CYRTF solids in the Y-12 SLF.

\subsubsection{Proposed projects}

The following projects have been proposed as upgrades to the Sanitary Wastewater Treatment System:

- Upgrade Sanitary Sewer System. This FY 1994 LI project will upgrade the ORNL Sanitary Sewage Collection, Treatment, and Disposal System. Improvements to the Sewage Collection System will include replacing undersized lines; installing new lines to outlying areas currently being served by the pump, haul, and tre it method; and reducing groundwater infiltration into the existing collection grid. Improvements to the Treatment and Disposal Systems will include reactivation of two existing sludge-drying beds, improvements to the 
Sludge-Drying System, and the upgrading of a Septic System in a remote area of ORNL. This project will improve the ability of ORNL's Sanitary Sewer System to meet the regulatory guidelines that govern discharges from the Sanitary Waste Treatment Facility.

- Wastewater Piping Replacement. This FY 1988 GPP project will reduce the amount of process cooling water and total residual chlorine discharged to the ORNL watershed. A recirculating Cooling Water System will be provided for the equipment in the Materials Testing Laboratory located in Building 4500S. The existing chilled water will provide the cooling load for the recycle system. A back-up Cooling Water System, with a Dechlorination System, will provide cooling in the event of the failure of the recycle Cooling Water System. These modifications are necessary because the Tennessee water quality regulations prohibit the discharge of water having residual chlorine concentrations greater than $0.25 \mathrm{ppm}$ to the watershed.

- Surface Water Monitoring Improvements. This FY 1988 GPP project will upgrade or replace six existing surface water flow-monitoring and sampling stations to allow data collection in accordance with DOE Orders 5400.1 and 5400.5 and the Environmental Regulatory Guide for Radiological Effluent Monitoring and Environmental Surveillance. The existing instrumentation at the six sites is inadequate for obtaining present data requirements.

- Chlorine Treatment for Cooling Water. This FY 1991 GPP project will assist ORNL in attaining compliance with the state of Tennessee water quality standards by reducing the quantity of chlorine discharged to WOC and address waste minimization objectives by removing nonradiological cooling water from the Process Waste System. A reduction in the quantity of free chlorine discharged to the watershed will be accomplished via chemical treatment of the cooling water in the storm sewer at selected sites. The treatment systems will include flow monitors, residual chlorine analyzer, pumps, holding tanks, and piping. Removal of cooling water from the Process Waste System will be accomplished by the installation of a recycle cooling loop in Building 3003. Items covered will include the installation of a chiller unit, a heat exchanger, a pump, piping, and the removal of existing equipment.

- Outfall 302 Storm Sewer Rehabilitation. This FY 1992 GPP will allow for the repair or replacement of the leaking Stormwater Collection System in the vicinity of the equalization basin such that contaminated groundwater infiltration does not occur. This rehabilitation will eliminate the possibility of large volumes of contaminated groundwater being discharged to the receiving stream. Additionally, the capability to collect, to transfer, and to treat the contaminated groundwater adjacent to the Stormwater Collection System at the Process Wastewater Treatment Plant will be provided.

- Outfall Dechlorination. This FY 1993 GPP will assist ORNL in attaining compliance with the state of Tennessee water quality standards by reducing the quantity of chlorine discharged to WOC. A reduction in the quantity of free chlorine discharged to the watershed will be accomplished via chemical treatment of the cooling water in the storm sewer at selected sites. The treatment systems will include flow monitors, residual chlorine analyzer, pumps, holding tanks, and piping.

\subsubsection{Storage and Disposal Facilities}

Sanitary wastewater at ORNL is collccted, treated, and discharged according to the parameters set forth in the NPDES permit for the site. Solids are collected, treated, and discharged in the Y-12 SLF according to regulations set forth by the TDEC. 


\subsubsection{Status of Support Systems}

ORNL provides training commensurate with the employee's job responsibility. No specific certification or database management program currently exists to address sanitary wastewater at ORNL other than the reporting requirements established in the NPDES permit.

\subsubsection{Line Item and General Plant Projects}

Table 6.1 lists the LI and GPPs for sanitary wastewater facilities at ORNL.

Table 6.1. Line item and general plant projects for sanitary wastewater facilities at Oak Ridge National Laboratory

\begin{tabular}{lcc}
\hline \multicolumn{1}{c}{ Title } & $\begin{array}{c}\mathrm{TEC}^{a} \\
(\$ \times 1000)\end{array}$ & Fiscal year \\
\hline \multicolumn{3}{c}{ Line item projects } \\
Upgrade Sanitary Sewer System & 16,650 & 1994 \\
& & \\
Wastewater Piping Replacement & 700 & 1988 \\
Surface Water Monitoring & 415 & 1988 \\
Chlorine Treatment for Cooling Water & 700 & 1991 \\
Outfall 302 Storm Rehabilitation & 1,065 & 1992 \\
Outfall Dechlorination & 501 & 1993 \\
\hline
\end{tabular}

"Total estimated cost.

\subsection{OTHER WASTE}

Other waste streams that are not considered industrial or sanitary wastes and are not discussed in other sections of this plan include stormwater runoff, once-through cooling water, cooling tower blowdown, wastewater from coal yard runoff, sulfuric acid tank diked area runoff, Steam Plant boiler blowdown, and water softener regenerant. The following subsections address each of these waste streams.

\subsubsection{Stormwater Runoff}

Approximately 130 stormwater discharges at ORNL have NPDES discharge permits. These discharges (shown in Figs. 6.10, 6.11, and 6.12 as Fifth Creek, First Creek, and WOC storm sewer outfalls respectively), all empty into receiving streams. Their sources originate from storm drains, parking lot runoff, roof drains, once-through cooling, and process and laboratory drain:- inese discharges require sampling and analysis to verify that each discharge is within NPDES permit limits. 


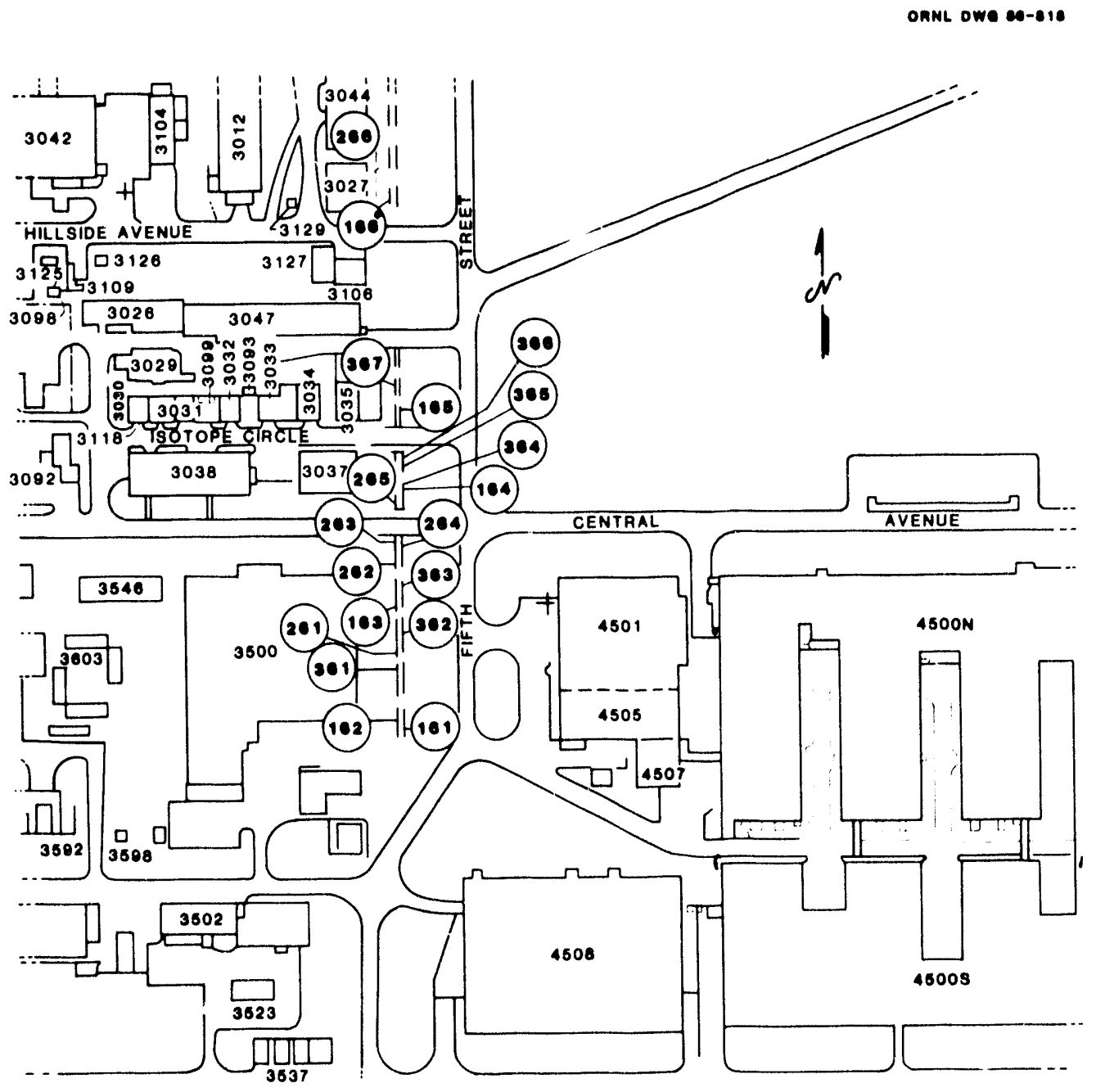

Fig, 6.10. Fifth Creek storm sewer outfalls.

\subsubsection{Once-Through Cooling Water}

Once-through cooling water for air compressors and other water-cooling systems at ORNL is dechlorinated in a large percentage of cases. Following dechlorination, the water is discharged as stormwater to the receiving stream.

\subsubsection{Cooling Tower Blowdown}

Cooling tower blowdown contains an assortment of biocides, corrosion inhibitors, and scale preventive chemicals. Because of their inert effects on the flora of the receiving streams, regulatory agencies have permitted ORNL to discharge cooling tower blowdown directly to the receiving streams. 


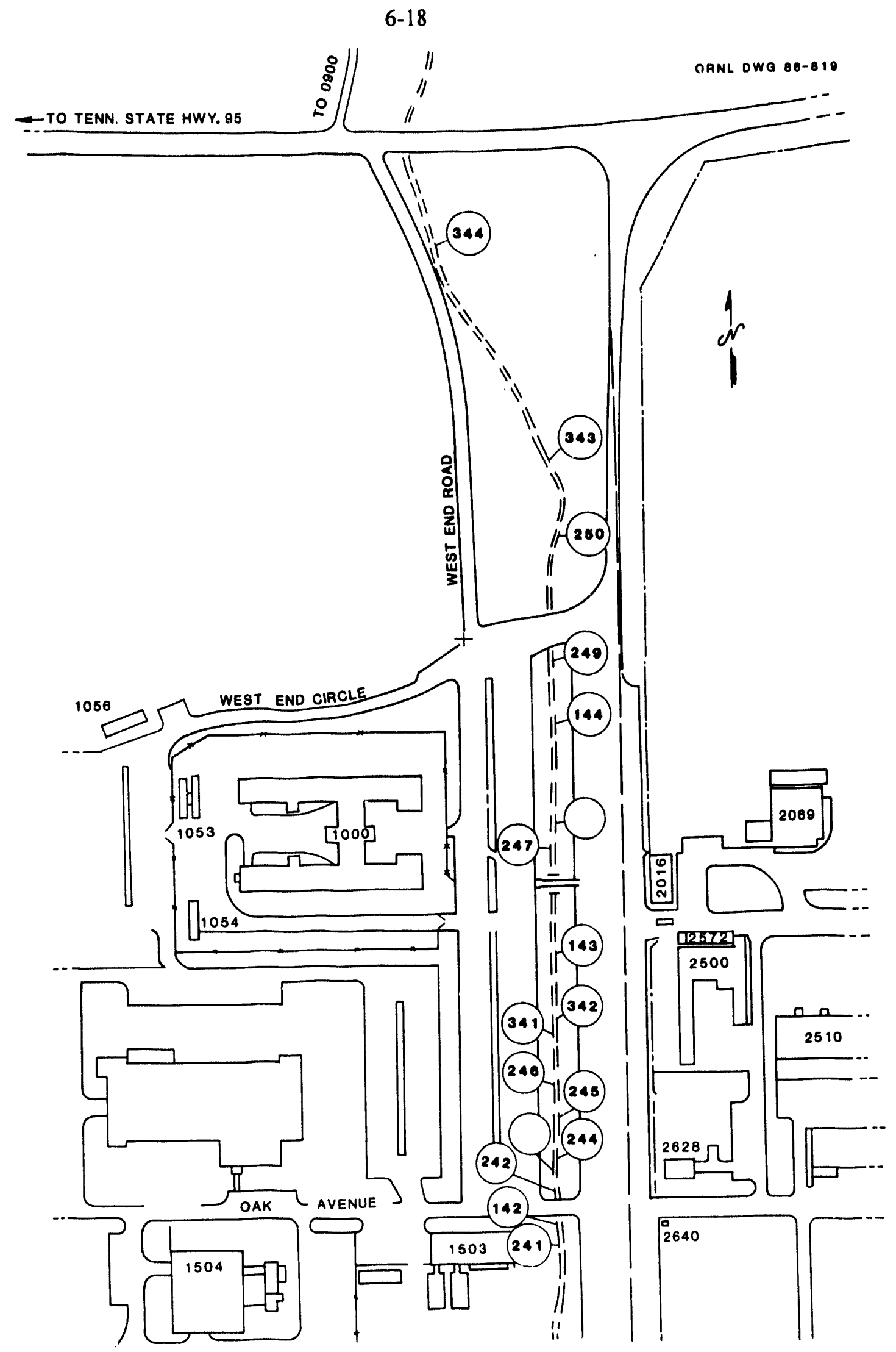

Fig. 6.11. First Creek storm sewer outfalls. 


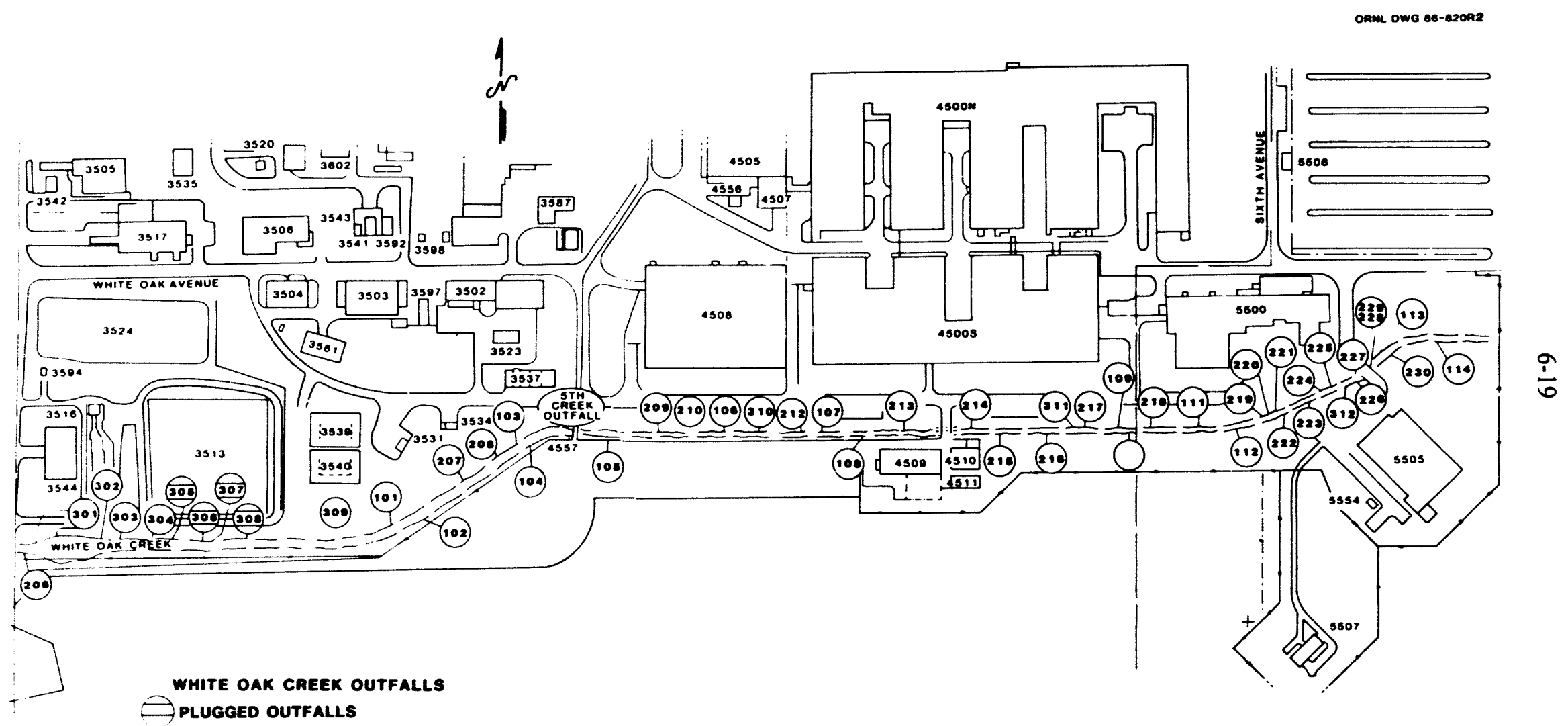

Fig. 6.12. White Oak Creek storm sewer outfalls. 


\subsubsection{Effluent from Coalyard Runoff Treatment Facility}

Wastewaters from coalyard runoff, including sulfuric acid tank-diked area runoff, Steam Plant boiler blowdown, and water softener regenerant, are treated as described in Subsect. 6.1.3 of this section. The treated clarifier effluent, plus the supernatant from the vacuum filter, flows by gravity to the lower holding pond and into WOC via an overflow wier. This liquid effluent is considered neither an industrial wastewater nor a sanitary wastewater. 


$$
\begin{aligned}
& \text { 震 }
\end{aligned}
$$

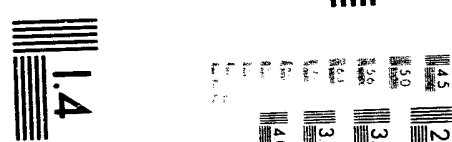

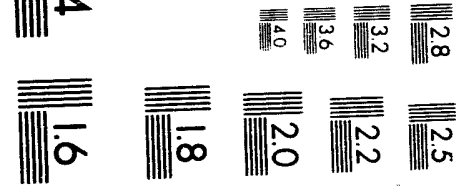



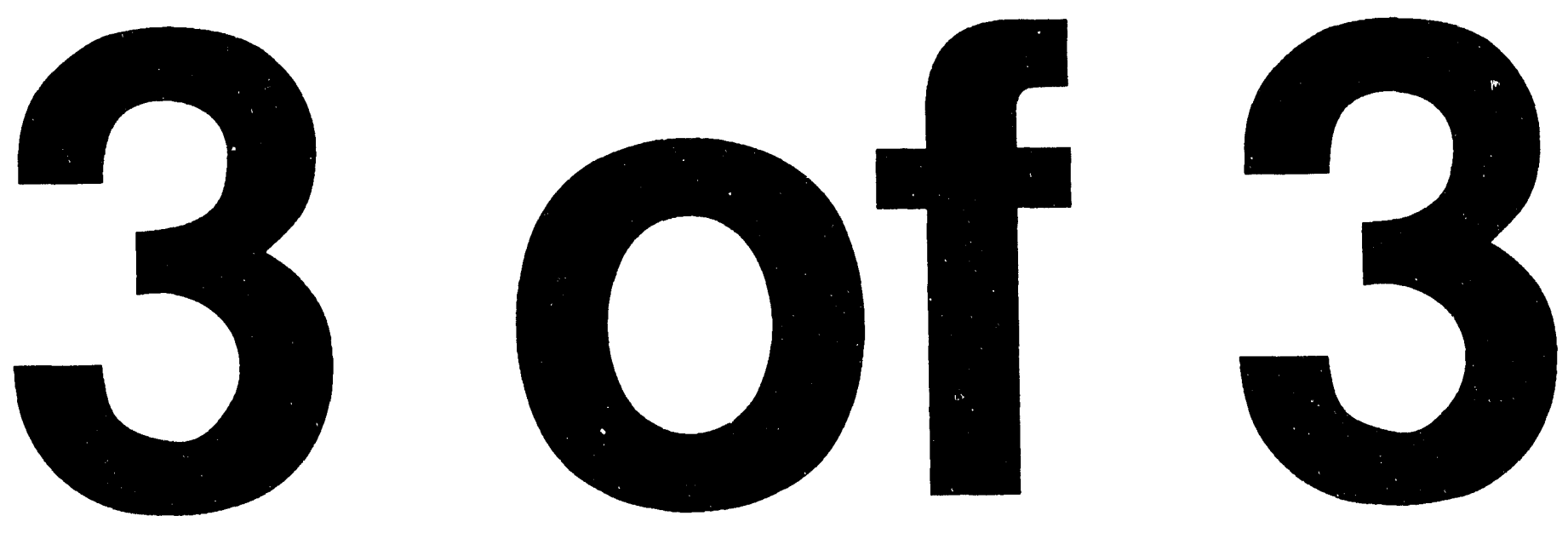



\section{DECONTAMINATION AND DECOMMISSIONING;}

Oak Ridge National Laboratory (ORNL) has many radioactively contaminated facilities, both operational and inactive, that must be managed in a manner that protects the health and safety of personnel and the general public as well as the environment and that eventually will require decontamination and decommissioning (D\&D). Also, future facilities will require $D \& D$ after operation. In general, D\&D activities are concerned with facilities such as reactors, hot cells, processing plants, some liquid low-level waste storage tanks, and other structures from which no known releases have occurred. The D\&D Program is a branch of the Environmental Restoration Program (ERP). The ERP is responsible for inactive waste sites and for soil and groundwater contamination from facilities where releases have occurred. At ORNL the Waste Management and Remedial Action Division (WMRAD) is directly responsible for surveillance and maintenance (S\&M) activities at inactive waste sites and S\&M and decommissioning activities for surplus facilities.

Management of these sites and facilities is coordinated through the Energy Systems ERP and the D\&D Program. The ORNL waste management activities associated with decontamination of radioactively contaminated facilities can be divided into four areas: operational facilities, inactive or surplus facilities, future facilities planning, and D\&D activities.

\subsection{OPERATIONAL FACILITIES}

Radioactively contaminated facilities that are currently operational are the responsibility of the line management organization assigned the facility. Funding for operation and maintenance of these facilities is provided by various program organizations within the U.S. Department of Energy (DOE). The operating organizations are responsible for maintaining the records for assigning fiscal responsibility for D\&D.

The operational safety of all active facilities are under the purview of the ORNL director of the Office of Operational Readiness and Safety. This office and various director review committees review the safety aspects associated with the operation of all new facilities and modifications to existing facilities. In addition, this office conducts periodic safety reviews and audits of all operational facilities. The director review committees include the Radioactive Operations Committee, the Reactor Operations Review Committee, and the Accelerators and Radiation Sources Review Committee. In operating facilities where, as the result of past facility operation, contamination is detected outside the facility proper (e.g., groundwater contamination), the ERP will be responsible for the planning and management of the necessary remedial actions.

\subsection{INACTIVE FACILITIES}

ORNL, which has been an operational site since the $1940 \mathrm{~s}$, has many inactive or surplus facilities. The overall strategy for the management of these inactive facilities is (1) to maintain and to monitor these facilities to ensure that the radioactivity is contained in a manner that limits exposure to personnel and the general public and protects the environment from potential hazards and (2) to plan for D\&D of these facilities.

The Surplus Facilities Management Program (SFMP) was established at ORNL in 1976 to provide collective management of all the surplus sites under ORNL control on the Oak Ridge Reservation. The program originally contained both civilian- and defense-related 
facilities and was administered by the SFMP office in Richland, Washington, through the SFMP identification. The defense surplus facilities program temporarily assumed the Defense Decontamination and Decommissioning Program (DDDP) title to differentiate it from its civilian counterpart. The SFMP and the DDDP did not include facilities that have been removed from service since 1976, and the need existed for a companion program that would include ER facilities and those that were utilized by several programs within ORNL. Therefore, the Surplus Contaminated Facilities Program (SCFP) was organized during the second half of FY 1985 to encompass the needs of surplus contaminated facilities at ORNL that were not part of the national SFMP. In 1989 these programs were integrated int the ER (EM-40) D\&D Program (EM-423), which is coordinated through the DOE Oak Ridge Operations Office and managed by the ORNL Remedial Action Section in WMRAD. The D\&D Program has established criteria for acceptance of new facilities into the program; not all of the SCFP facilities have been accepted. Table 7.1 lists those facilities that have been included in the D\&D Program since 1976. The Oak Ridge Research Reactor is expected to be transferred to the D\&D Program at the beginning of FY 1994. Table 7.2 lists surplus facilities that are expected to be transferred into the Facility Transition and Management Program (EM-60) in FY 1994 following the complete review of acceptance criteria. Former ER-supported surplus facilities that do not meet the D\&D Program acceptance criteria are listed in Table 7.3. Table 7.4 lists inactive sites that are supported and will ultimately be remediated by the Environmental Restoration Remedial Action Program. At ORNL, inactive facilities supported by EM-40 are managed by the Remedial Action Section in WMRAD. This responsibility includes evaluating current facility conditions, monitoring site surveillance information, and reviewing applicable environmental regulations to ensure that current decommissioning priorities reflect the requirement. Significant changes in these areas that impact decommissioning plans are conveyed routinely to the respective DOE program sponsor. The Office of Operational Readiness and Safety is responsible for reviewing and auditing surplus facilities.

\subsection{FUTURE FACILITIES}

Planning for D\&D, an integral part of the design of all future facilities at ORNL, will be the responsibility of the Energy Systems line organization responsible for operating the facility and will be in conjunction with architectural-engineering organizations involved in the design process. Funding for D\&D planning will be part of the design funding provided by the program sponsoring the facility.

\subsection{DECONTAMINATION AND DECOMMISSIONING GOALS}

The goals of D\&D are (1) to decontaminate facilities designated for reuse to the uxtent necessary for compliance with approved health and safety standards and (2) to decommission all other facilities in accordance with the requirements set forth in DOEapproved project plans and environmental compliance documentation. The ORNL, D\&D Program is implemented by the Remedial Action Section in WMRAD. Coordination of D\&D planning is also the responsibility of the Remedial Action Section. This organization will also ensure compliance with the requirements of DOE Order 5820.2A. Coordination and implementation technology developed at other DOE sites and the private sector are a part of the responsibility. A list of facilities currently scheduled for D\&D is provided in Table 7.5. 
Table 7.1. Facilities included in the Decontamination and Decommissioning Program since 1976

\begin{tabular}{|c|c|}
\hline $\begin{array}{c}\text { Building } \\
\text { number }\end{array}$ & Facility name/description \\
\hline 3001 & Oak Ridge Graphite Reactor (O(jR) \\
\hline $30 n 2$ & OGR Filter Housc \\
\hline 3003 & OGR Fan House \\
\hline 3005 & Low-Intensity Test Reactor (IITR) \\
\hline 3018 & Exhaust stack for 30013 (OCiR stack) \\
\hline 3042 & Reactor experiments (ORR) $)^{\mu}$ \\
\hline 3077 & Air cooler (I.ITR) \\
\hline 3087 & Heat exchanger ((ORR) \\
\hline 3505 & Metal Recovery lacility \\
\hline 3506 & Waste evaporator \\
\hline 3515 & Fission Product Pilot Plant \\
\hline 3517 & Fission Product Development Laboratory (inactive cells) \\
\hline 4507 & Iligh-Radiation-level (hemical Development laboratory \\
\hline 7500 & Homogeneous Reactor lixperiment (IIRI:) \\
\hline 7502 & Waste evaporator (HRIE) \\
\hline 7503 & Molten Salt Reactor lixperiment (MSRL) \\
\hline 7511 & liilter pit (MSRE) \\
\hline 7512 & Exhaust stack (MSRI:) \\
\hline 7513 & Cooling tower (MSRE) \\
\hline 7514 & Supply Air Filter House (MSRE) \\
\hline 7554 & Cooling tower (HRE) \\
\hline 7555 & Diesel Generator llouse (MSRE) \\
\hline 7557 & (harcoal absorber pit (IIRI:) \\
\hline 7558 & Waste evaporator loading pit (HRE) \\
\hline 7559 & Chareoal absorber valve pit (IIRI:) \\
\hline 7561 & Waste valve pit (IIRL) \\
\hline 7852 & Old Hydrofracture racility \\
\hline $9201-3$ & Molten Salt Reactor Experiment Fuel-I landling Facility \\
\hline $9201-3$ & Coolant Salt Technology Facility \\
\hline $9201-3$ & Storage tank \\
\hline $9419-1$ & Decontamination Facility \\
\hline -..- & Shiclded transfer tanks ST1, ST2, ST3, ST4, STS \\
\hline
\end{tabular}

"Oak Ridge Research Reactor.

\subsection{UPDATE OF IMPLEMENTATION SUMMARY TABLE}

Appendix A provides an update to the original implementation summary for decommissioning of radioactively contaminated facilities that was provided in the ORNL Waste Management Plan for DOE Order 5820.2A. The format in Appendix A duplicates the format of the requirements for the decommissioning of radioactively contaminated facilities contained in DOE Order 5820.2A. Many activities planned for achieving compliance with the order are applicable to more than one requirement. To avoid duplication of costs for achieving compliance, cross-referencing between requirements is used extensively. 
Table 7.2. Former Energy Research-supported surplus facilities expected to be transferred to the

Decontamination and Decommissioning Program in FY 1994

\begin{tabular}{cl}
$\begin{array}{c}\text { Facility } \\
\text { number }\end{array}$ & \multicolumn{1}{c}{ Facility name/description } \\
\hline 3110 & Filter House (and underground ductwork) \\
3121 & Off-Gas Filter House \\
7819 & Interim Decontamination Facility \\
\hline
\end{tabular}

Table 7.3. Former Energy Research-supported surplus facilities not meeting Decontamination and

Decommissioning Program acceptance criteria

\begin{tabular}{ll}
\hline $\begin{array}{c}\text { Facility } \\
\text { number }\end{array}$ & \multicolumn{1}{c}{ Facility name/description } \\
\hline $3019-\mathrm{B}$ & High-Radiation-Level Analytical Facility \\
3028 & Strontium-90 power generators \\
3029 & Cobalt-60 storage garden \\
3503 & Storage pad \\
$9201-2$ & ORNL 218-cm (86-in.) cyclotron \\
$9204-3$ & Plutonium Processing Facility \\
$9204-3$ & Curium-handling glovebox \\
$9204-1$ & Attic \\
$9204-1$ & East End basement \\
\hline
\end{tabular}


Table 7.4. Facilities or sites under the Environmental

Restoration Program

\begin{tabular}{|c|c|}
\hline $\begin{array}{l}\text { Facility } \\
\text { number }\end{array}$ & Facility name/description \\
\hline \multicolumn{2}{|r|}{ Defense programs } \\
\hline 1001 & Solid Waste Storage Area 3 \\
\hline 2624 & Solid Waste Storage Area 1 \\
\hline 3023 & North Tank Farm \\
\hline 3075 & Decommissioned Low-Intensity Test Reactor Ponds \\
\hline 3507 & South Tank Farm \\
\hline 3512 & Decommissioned waste-holding basin \\
\hline 3513 & Waste-holding basin \\
\hline 4003 & Solid Waste Storage Area 2 \\
\hline 7556 & Settling pond-Homogenous Reactor Experiment (HRE) \\
\hline 7560 & Waste tank, HRE $[3785 \mathrm{~J},(1000 \mathrm{gal})]$ \\
\hline 7562 & Waste condensate tank, HRE $[45,425$ L $(12,000$ gal $)]$ \\
\hline 7800 & Solid Waste Storage Area 4 \\
\hline 7802 & Solid Waste Storage Area 5 \\
\hline 7805-7808 & Chemical waste pits $1-4$ \\
\hline 7809 & Chemical waste trench 5 \\
\hline 7810 & Chemical waste trench 6 \\
\hline 7818 & Chemical waste trench 7 \\
\hline 7835 & Sludge waste pond (SWSA 5) \\
\hline $7852 \mathrm{~A}$ & Old Hydrofracture Facility (OHF) Pond \\
\hline 7854 & Drilling equipment storage (OHF) \\
\hline -.-- & Hydrofracture Experimental Site 1 \\
\hline---- & White Wing scrap yard \\
\hline$\cdots$ & Fission Products Development Laboratory low-level waste transfer line \\
\hline$-\cdots$ & SWSA 6 Resource Conservation and Recovery Act-capped areas \\
\hline$\cdots$ & OHF tanks (T-1, T-2, T-3, T-4, T-9) \\
\hline$\cdots$ & $\begin{array}{l}\text { Other low-level waste (LLW) tanks (WC-1, TH-1, TH-2, TH-3, TH-4, } \\
\text { WC-15, WC-17, T-30) }\end{array}$ \\
\hline \multicolumn{2}{|r|}{ Energy Research } \\
\hline 0800 & Environmental Study Area $\left({ }^{137} \mathrm{Cs}\right.$ plots $)$ \\
\hline 7658 & Closed Contractor's Landfill \\
\hline$\cdots$ & Transfer Line Leak Site (Building 7819 to pit) \\
\hline$-\cdots$ & LLW Line Leak Site 1 (southeast of trench 6) \\
\hline$\ldots$ & LLW Line Leak Site 2 (north of trench 7) \\
\hline$\ldots$ & Chestnut Ridge cesium plots \\
\hline
\end{tabular}


Table 7.5. Decommissioning of surplus facilities: long-range schedule

\begin{tabular}{lc}
\hline \multicolumn{1}{c}{ Decommissioning project } & $\begin{array}{c}\text { Projected schedule } \\
(\text { FY) }\end{array}$ \\
\hline Metal Recovery Facility & $1993-2006$ \\
Waste Evaporator Facility & $1993-1997$ \\
Fission Product Pilot Plant & $1993-1997$ \\
Old Hydrofracture Facility & $1993-2001$ \\
Shielded Transfer Tanks & $2002-2006$ \\
Decontamination Facility & $2005-2009$ \\
Oak Ridge Research Reactor Heat Exchangers & $2003-2007$ \\
Homogeneous Reactor Experiment & $2000-2009$ \\
Molten Salt Corrosion Loop & $2010-2014$ \\
Low-Intensity Test Reactor & $2007-2013$ \\
Molten Salt Reactor Experiment & $2001-2016$ \\
Fission Products Development Laboratory Inactive Cells & $2006-2011$ \\
Coolant Salt Technology Facility & $2011-2014$ \\
ORNL Graphite Reactor & $2008-2017$ \\
Oil Storage Tank & $2012-2015$ \\
High-Level Chemical Development Laboratory & $2009-2017$ \\
Oak Ridge Research Reactor and Experimental Facilities & $2004-2019$ \\
\hline
\end{tabular}




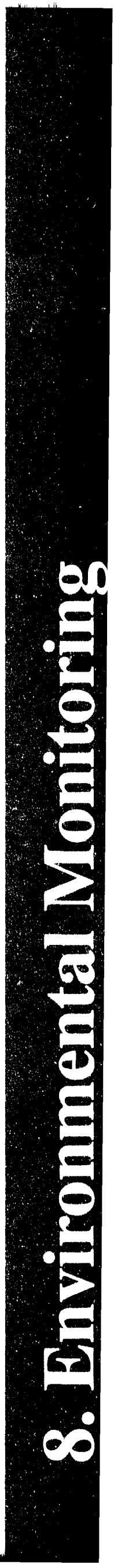




\section{ENVIRONMENTAL MONITORING}

The Active Sites Environmental Monitoring Program, initiated in 1989, provides early detection and performance monitoring of transuranic (TRU) waste and active low-level waste (LLW) facilities at Oak Ridge National Laboratory in accordance with U.S. Department of Energy (DOE) Order 5820.2A. The program is implemented by the Environmental Sciences Division for Solid Waste Operations.

\subsection{ACTIVE LOW-LEVEL WASTE FACILITIES}

Active LLW facilities in Solid Waste Storage Area (SWSA) 6 include Tumulus 1 and Tumulus II, the Interim Waste Management Facility (IWMF), LLW silos, high-range wells, asbestos silos, and fissile wells. The tumulus pads and IWMF are aboveground, highstrength concrete pads on which concrete vaults containing metal boxes of LLW are placed; the void space between the boxes and vaults is filled with grout. Eventually, these pads and vaults will be covered by an engineered multilayered cap. All other LLW facilities in SWSA 6 are below ground. In addition, monitoring of the Hillcut Disposal Test Facility (HDTF) in SWSA 6 is performed even though this facility was completed prior to the date of the DOE order. In SWSA $5 \mathrm{~N}$ the TRU facilities include below-grade engineered caves, high-range wells, and unlined trenches.

\subsection{MONITORING ACTIVITIES}

Monitoring activities at each facility are based on the most current conceptual model of the hydrology in each area as well as site-specific characteristics. In all areas water is the primary vector for contaminant transport. In SWSA 6 water can move as shallow stormflow within the upper 1 to $2 \mathrm{~m} \mathrm{(3} \mathrm{to} 6 \mathrm{ft}$ ) of soil or as groundwater in the shallow aquifer. As stormflow intercepts the unlined burial trenches, water enters the trenches faster than it can flow out, and a perched water table is formed. This perched water table subsequently acts to recharge the shallow aquifer. Hence, it is important to monitor the perched water table in the trenches and in the small quantity of backfill around high-range wells, asbestos silos, and fissile wells.

The tumulus pads and IWMF are aboveground facilities that require a different monitoring approach from that for buried wastes. The pads provide the first line of containment for any waste material that might escape from the concrete vaults. Water accumulating on, or running off, the pads is monitored. Should the pads also leak, the gravel base below the pads would accumulate the contamination, and that water is also drained away from the pads and monitored. Groundwater around the pads is also monitored to determine if any contamination has escaped from the pads and gravel base and to provide the hydrogeochemical data to predict the rate of transport should any contamination be detected.

The perched water table in the LLW silo trenches is sampled through the use of wells that are installed in the trench tackfill. Similar wells are also installed in the backfill adjacent to the high-range wells, asbestos silos, and fissile wells.

The HDTF, which is very similar to a tumulus-type facility that is already buried, is monitored through collection and sampling of water that accumulates on the concrete pad 
and in the gravel base. Monitoring wells have also been installed on the pad and into the gravel base, and these wells are checked regularly.

In SWSA $5 \mathrm{~N}$ there is evidence that transport through the shallow aquifer, especially along preferred pathways, may be more important than shallow stormflow. Thus, in this area, monitoring activities focus on groundwater monitoring wells, seeps, and samples from small tributaries.

All samples from SWSA 6 are screened for alpha and beta activity, counted for gamma-emitting isotopes, and analyzed for tritium. In addition to these analytes, samples from SWSA $5 \mathrm{~N}$ are analyzed for specific transuranic elements. 


\section{SUPPORT ACTIVITIES}

Developing the capabilities necessary for Oak Ridge National Laboratory (ORNL) to achieve and to maintain full compliance with environmental regulations and waste management objectives requires the integration of a large number of individual projects and activities. The following subsections provide information on ORNL waste management support activities.

\subsection{STORAGE, TREATMENT, AND DISPOSAL PLAN}

Temporary storage of transuranic (TRU), hazardous, and mixed wastes has been part of the ORNL waste management strategy since the 1970s. Solid low-level waste (SLLW) was added to the category of stored waste beginning in 1986 when these wastes were first shipped to the Oak Ridge K-25 Site. TRU, mixed, and SLLW storage is expected to be a critical part of ORNL plans for the foreseeable future until treatment and/or disposal facilities are developed and made available.

Appendix $C$ lists the ORNL waste treatment, storage, and disposal facilities, along with the status of each, and includes information on wastes in temporary staging as well as those in long-term storage modes. Capacity concerns exist for contact-handled (CH) TRU, remote-handled ( $\mathrm{RH}) \mathrm{TRU}$, hazardous, and mixed wastes. Appendix $\mathrm{C}$ also indicates the Resource Conservation and Recovery Act (RCRA) permit status for each storage facility. Several of the interim status facilities initiated closure during 1992. Closure plans were revised and have been submitted to the Tennessee Department of Environment and Conservation (TDEC) for approval.

Based on the current understanding of the storage needs, the need for additional storage facilities for SLLW, CH TRU, RH TRU, hazardous, and mixed waste is anticipated. Currently planned facilities for ORNL wastes arc presented in Table 9.1. The CH TRU, RH TRU, hazardous, and mixed waste facilities will require RCRA permitting.

\subsection{WASTE REDUCTION}

Waste reduction and pollution prevention has received significant publicity and regulatory attention in recent years and will be an important part of reducing waste disposal liabilities for the generating community during the next decade. Federal regulations, U.S. Department of Energy (DOE) policies and guidelines, increased costs and liabilities associated with the management of wastes, limited disposal options and facility capacities, and public consciousness have been motivating factors for comprehensive waste reduction programs.

The ORNL Waste Minimization/Reduction and Pollution Prevention Program is designed to reduce the amounts and toxicity of ORNL's wastes, to encourage waste reduction technology development, and to promote increased awareness among ORNL employees. This program applies to all waste streams generated by ORNL operations including transuranic, solid low-level, liquid low-level, process, gaseous, hazardous and lowlevel mixed, and sanitary and industrial. A detailed description of the scope of this program is given in the Oak Ridge National Laboratory Waste Minimization/Reduction and Pollution Prevention Program Plan. 


\section{$9-4$}

Table 9.1. Planned storage facility construction/upgrades

\begin{tabular}{|c|c|c|c|}
\hline Project & $\begin{array}{l}\text { Project } \\
\text { type }\end{array}$ & $\begin{array}{l}\text { Expected } \\
\text { operational } \\
\text { startup }\end{array}$ & Planned use \\
\hline \multicolumn{4}{|c|}{ Hazardous waste } \\
\hline $\begin{array}{l}\text { Polychlorinated biphenyl } \\
\text { (PCB) Annex to } \\
\text { Building } 7652\end{array}$ & $\begin{array}{l}\text { FY } 1989 \\
\text { GPP }^{a}\end{array}$ & TBD & $\begin{array}{l}\text { Provide staging area for PCB waste prior to } \\
\text { off-site shipment }\end{array}$ \\
\hline \multicolumn{4}{|c|}{ Mixed waste } \\
\hline $\begin{array}{l}\text { Expand mixed waste } \\
\text { storage (Building 7668) }\end{array}$ & $\begin{array}{l}\text { FY } 1989 \\
\text { GPP }\end{array}$ & FY 1995 & $\begin{array}{l}\text { Provide long-term storage of drummed/boxed } \\
\text { mixed waste }\end{array}$ \\
\hline $\begin{array}{l}\text { Mixed Waste Storage Facility } \\
\text { (Building 7669) }\end{array}$ & $\begin{array}{l}\text { FY } 1993 \\
\text { GPP }\end{array}$ & FY 1996 & $\begin{array}{l}\text { Provide long-term storage of drummed/boxed } \\
\text { mixed waste }\end{array}$ \\
\hline \multicolumn{4}{|c|}{ Recyclable material } \\
\hline Upgrade Building 7507 & $\begin{array}{l}\text { FY } 1990 \\
\text { GPP }\end{array}$ & TBD & $\begin{array}{l}\text { Upgrade building to provide staging area for } \\
\text { contaminated recyclable lead and/or } \\
\text { hazardous waste storage }\end{array}$ \\
\hline \multicolumn{4}{|c|}{ Solid low-level waste (SLLW) } \\
\hline $\begin{array}{l}\text { Bulk Contaminated Soil } \\
\text { Facility }\end{array}$ & $\begin{array}{l}\text { FY } 1991 \\
\text { GPP }\end{array}$ & FY 1994 & $\begin{array}{l}\text { Provide storage for radioactively } \\
\text { contaminated soils }\end{array}$ \\
\hline $\begin{array}{l}\text { Class L-III and L-IV Below- } \\
\text { ground Storage Facility }\end{array}$ & $\begin{array}{l}\text { FY } 1991 \\
\text { GPP }\end{array}$ & FY 1995 & $\begin{array}{l}\text { Provide storage for Class L-III/L-IV SLLW } \\
\text { in stainless steel wells prior to off-site } \\
\text { shipment for disposal }\end{array}$ \\
\hline $\begin{array}{l}\text { Class L-III and L-IV Above- } \\
\text { ground Storage Facility }\end{array}$ & $\begin{array}{l}\text { FY } 1992 \\
\text { GPP }\end{array}$ & FY 1995 & $\begin{array}{l}\text { Provide storage for Class L-III/L-IV SLLW } \\
\text { in aboveground concrete modules prior to } \\
\text { off-site shipment for disposal }\end{array}$ \\
\hline SLLW Staging Facility & $\begin{array}{l}\text { FY } 1993 \\
\text { GPP }\end{array}$ & TBD & $\begin{array}{l}\text { Provide staging/storage for SLLW and mixed } \\
\text { waste }\end{array}$ \\
\hline $\begin{array}{l}\text { Class L-III and L-IV } \\
\text { Retrievable Storage } \\
\text { Facility II }\end{array}$ & $\begin{array}{l}\text { FY } 1995 \\
\text { GPP }\end{array}$ & TBD & $\begin{array}{l}\text { Expand Class L-III/L-IV retrievable } \\
\text { storage wells }\end{array}$ \\
\hline $\begin{array}{l}\text { SWSA } 7 \text { Aboveground } \\
\text { Storage Facility }\end{array}$ & $\begin{array}{l}\text { FY } 1996 \\
\text { GPP }\end{array}$ & TBD & $\begin{array}{l}\text { Expand aboveground storage for } \\
\text { Class L-III/L-IV SLLW }\end{array}$ \\
\hline \multicolumn{4}{|c|}{ Transuranic (TRU) waste } \\
\hline $\begin{array}{l}\text { Contact-handled } \\
\text { transuranic (CH TRU) } \\
\text { Storage Facility }\end{array}$ & $\begin{array}{l}\text { FY } 1990 \\
\text { GPP }\end{array}$ & FY 1994 & $\begin{array}{l}\text { Provide RCRA-approved }{ }^{d} \text { storage for } \mathrm{CH} \\
\text { TRU drums prior to } \\
\text { repackaging/shipment to the Waste } \\
\text { Isolation Pilot Plant (WIPP) }\end{array}$ \\
\hline $\begin{array}{l}\text { Nuclear Fuel Services, Inc. } \\
\text { (NFS) CH TRU Storage } \\
\text { Facility }\end{array}$ & $\begin{array}{l}\text { FY } 1992 \\
\text { GPP }\end{array}$ & FY 1994 & $\begin{array}{l}\text { Provide RCRA-approved storage for NFS } \\
\mathrm{CH} \text { TRU drums prior to } \\
\text { repackaging/shipment to WIPP }\end{array}$ \\
\hline TRU Waste Storage Facility & $\begin{array}{l}\text { FY } 1995 \\
\text { GPP }\end{array}$ & TBD & $\begin{array}{l}\text { Provide RCRA-approved storage for } \mathrm{CH} \\
\text { TRU drums prior to repackaging/shipment } \\
\text { to WIPP }\end{array}$ \\
\hline $\begin{array}{l}\text { Remote-handled TRU } \\
\text { Storage Bunker }\end{array}$ & $\begin{array}{l}\text { FY } 1989 \\
\text { GPP }\end{array}$ & FY 1995 & $\begin{array}{l}\text { Provide RCRA-approved storage for RH } \\
\text { TRU casks prior to processing at the Waste } \\
\text { Handling and Packaging Plant }\end{array}$ \\
\hline $\begin{array}{l}\text { Retrieved RH TRU Cask } \\
\text { Storage Bunker }\end{array}$ & $\begin{array}{c}\text { FY } 1997 \\
\text { LI }\end{array}$ & FY 2000 & $\begin{array}{l}\text { Provide temporary storage of retrieved RH } \\
\text { TRU waste prior to repackaging/shipment } \\
\text { to WIPP }\end{array}$ \\
\hline
\end{tabular}

\footnotetext{
${ }^{a}$ General plant project.

${ }^{b}$ Out-year project; no completion or start date has yet been assigned.

${ }^{c}$ Line item.

${ }^{d}$ Resource Conservation and Recovery Act.
} 


\subsubsection{Objectives}

The overall waste reduction objective is twofold: (1) prevention of future liabilities and (2) elimination of environmental releases by continued development of an aggressive waste reduction program together with leadership and direction for having a comprehensive program plan in place by 1994 containing challenging, concrete goals for waste reduction in the cut-years. Specific objectives of this program are:

- to foster a Laboratory-wide philosophy to conserve resources, to reduce the cost of research and development (R\&D) activities, and to create a minimum of waste and pollution in achieving site strategic objectives through developing and implementing techniques, technologies, and programs that minimize waste generation;

- to promote the use of nonhazardous materials in ORNL activities to minimize the potential risks to human health and the environment;

- to reduce or to eliminate the generation of waste materials through input substitution, product reformulation, process or laboratory operational modification, improved housekeeping, and on-site closed-loop recycling to achieve minimal adverse effects on the air, water, and land; and

- to comply with federal and state regulations and DOE requirements for waste minimization/reduction and pollution prevention.

\subsubsection{Strategy}

This program (1) supports the implementation of systems to provide accurate and current waste-stream-specific information that will ultimately provide baseline information to support the implementation of specific waste minimization/reduction techniques and technologies and (2) develops methods for collecting information, evaluating options, and identifying cost-effective waste minimization/reduction techniques. The essential elements of the program strategy are (1) maintenance of an organization that comprises management and staff representatives who continue to develop and to administer the program, (2) definition of wastes to be targeted for reduction, (3) development of a method for tracking performance and progress of the program, and (4) fostering and encouragement of the awareness of environmental problems and the philosophy that includes waste minimization/reduction.

The strategy focuses on four major elements: (1) the evaluation of laboratory and support operations for waste minimization/reduction opportunities and associated projects including R\&D, (2) the waste minimization/reduction promotional campaign, (3) tracking activities (including wastes), and (4) the exchange of information and technology.

\subsubsection{Goals}

The program's numerical goals for the minimization/reduction of the types of wastes generated at ORNL are currently waste-stream-specific based on 1991 generation rates (Table 9.2). These goals may be revised and division-specific goals established after ORNL. waste streams are prioritized for subsequent Process Waste Assessments as needed. If additional regulatory goals are established in the future, the program goals will be evaluated and adjusted as applicable to ensure compliance. 
Table 9.2. Oak Ridge National Laboratory waste minimization/reduction goals ${ }^{a}$ Based on CY 1991 routine waste generation rates

\begin{tabular}{|c|c|c|c|c|}
\hline \multirow{2}{*}{ Waste stream $^{b}$} & \multirow{2}{*}{$\begin{array}{c}\text { Generation rate } \\
\text { CY } 1991\end{array}$} & \multicolumn{3}{|c|}{ Goals (\%) } \\
\hline & & CY 1995 & CY 1998 & CY 2002 \\
\hline Hazardous & $c$ & 25 & 70 & 75 \\
\hline Mixed & $85,916 \mathrm{~kg}(189,412 \mathrm{lb})$ & 25 & 70 & 75 \\
\hline Transuranic & $15 \mathrm{~m}^{3}\left(530 \mathrm{ft}^{3}\right)$ & 10 & 15 & 20 \\
\hline Solid low-level ${ }^{d}$ & $1,200 \mathrm{~m}^{3}\left(42,372 \mathrm{ft}^{3}\right)$ & 25 & 50 & 60 \\
\hline Liquid low-level & $2,050 \mathrm{~m}^{3}\left(72,386 \mathrm{ft}^{3}\right)$ & 30 & 60 & 70 \\
\hline Process & $284,000 \mathrm{~m}^{3}\left(10,028,040 \mathrm{ft}^{3}\right)$ & 25 & 50 & 75 \\
\hline Industrial/sanitary ${ }^{d}$ & $15,240 \mathrm{~m}^{3}\left(538,124 \mathrm{ft}^{3}\right)$ & 50 & 75 & 80 \\
\hline
\end{tabular}

${ }^{a}$ Environmental remediation waste (ERW) will be tracked separately from the rest of the waste generated at ORNL. The ORNL goals do not apply to ERW; therefore, these wastes will not be included on the total waste tracked related to these goals. The rationale for these goals is based on a cursory review that indicates that several of ORNL's waste streams have potential for the application of successful waste minimization/reduction techniques. The listed waste-stream-based goals may be revised based on the ORNL program Process Waste Assessments (PWAs) to be performed in the future and may be modified to a per:unit basis if the ORNL program determines that an appropriate unit exists for a research and development facility. Additionally, if goals are established related to the Federal Facilities Compliance Agreement for Storage of Radioactive Mixed Waste Subject to Land Disposal Restrictions for the Oak Riaye Reservation, ORNL will prioritize the implementation of waste minimization/reduction projects and activities to support these goals.

${ }^{b}$ After the ORNL PWAs are completed, waste-stream-specific reduction goals may be revised for ORNL wastes. Hazardous waste includes those wastes as defined under the Resource Conservation and Recovery Act.

'The routine hazardous waste generation rate for 1991 was included in the routine mixed waste value.

${ }^{d}$ Any operations that may generate asbestos-containing materials as wastes will be evaluated specifically to reduce the volume of these wastes.

In addition to program and division-specific goals, Martin Marietta Energy Systems, Inc., has adopted the following goals in the ES\&H Management Plan for Oak Ridge National Laboratory:

- reduction of the Superfund Amendments and Reauthorization Act 313 toxic chemical releases to $50 \%$ of the 1988 level and to $5 \%$ of the 1991 level by the years 1995 and 2000 respectively,

- reduction of the release levels of 17 high-priority toxic chemicals identified in the U.S. Environmental Protection Agency's 33/50 program by 50\% of the 1988 quantity by 1995 ,

- reduction of the emission of ozone depleting chemicals, and

- reduction of industrial/sanitary solid waste disposal to $50 \%$ of the 1991 level and to $25 \%$ of the 1991 level by 1995 and 2000 respectively. 


\subsubsection{Regulatory Requirements}

This program is driven by the following legal and policy-based requirements:

- the Hazardous and Solid Waste Amendments to RCRA;

- the Pollution Prevention Act of 1990;

- the Oak Ridge Reservation Federal Facilities Compliance Agreement;

- the Tennessee Hazardous Waste Reduction Act and hazardous waste regulations;

- The Tennessee/DOE Oversight Agreement;

- DOE Orders 5400.1, 5820.2A, and 5400.3;

- Executive Order 12780;

- DOE policies;

- DOE radiological control requirements; and

- internal policies and Best Management Practices.

\subsection{WASTE CERTIFICATION}

The Energy Systems Solid Waste Certification Program Plan is based on the concept that site waste management organizations will establish Waste Acceptance Criteria (WAC) against which waste handled at those facilities can be certified. In addition, DOE Order 5820.2A specifies the development of WAC by each radioactive and mixed waste storage, treatment, and disposal facility that must be met by generators seeking to utilize the facility. WAC not only establish the minimum acceptable amount of information that must be known about a waste but also define certain acceptable waste characteristics. This order requires that radioactive and mixed wastes be managed in a manner that ensures protection of the health and safety of the public, DOE, contractor employees, and the environment. It is the policy of ORNL (1) to store or to dispose of radioactive solid waste that is nonhazardous within the context of RCRA in a manner that adequately protects personnel, the general population, and the environment and (2) to conduct disposal and storage operations in accordance with established requirements as specified in DOE orders and ORNL manuals and procedures.

The purpose of the ORNL Waste Certification Program is to ensure, in a manner consistent with DOE Order 5820.2A and the Energy Systems Solid Waste Certification Program, that wastes generated are capable of being certified against the WAC for the storage, treatment, or disposal facilities to which they are sent. This program applies to all operations that involve the generation, shipment, storage, treatment, and disposal of wastes destined for ORNL storage, treatment, and disposal facilities.

\subsubsection{Historical Development}

The ORNL Solid Waste Certification Program began with the need to certify TRU waste for acceptance at the Waste Isolation Pilot Plant (WIPP). WIPP WAC require that a generator facility have in place a WIPP-approved waste certification program before generating TRU waste destined for WIPP. After receiving WIPP approval in June 1986, ORNL implemented a certification program for the newly generated $\mathrm{CH}$ TRU as described in the ORNL TRU Waste Certification Program Plan.

Concurrently with the development of the TRU Waste Certification Program, lowlevel radioactive waste disposal operations in Solid Waste Storage Area (SWSA) 6 at ORNL 
were halted by the DOE Oak Ridge Operations Office (DOE-ORO). The order was issued because of concern that RCRA hazardous and mixed wastes were being disposed of in SWSA 6 in violation of RCRA. Insufficient administrative and process controls were in place to verify that RCRA materials were not being disposed of in SWSA 6. As a result of this action, and to bring SWSA 6 back into active operation, a SLLW Certification Program was initiated. The immediate goal of the program was improvement of the segregation of RCRA materials from SLLW and better documentation of the constituents of the waste. At that time the SLLW Certification Program consisted of the following elements:

- establishment of a training program for operators and supervisors in areas generating SLLW that would (1) focus on the requirements for packaging, proper documentation, acceptable characteristics, and excluded materials and (2) contain restrictions against untrained personnel being allowed to package SLLW;

- development of documentation to track the contents of individual waste packets being placed into the SLLW container;

- reviews of generator SLLW programs; and

- verification of SLLW package contents by real-time radiography.

With the issuance of DOE Order 5820.2A, additional program elements needed addressing. One of the changes requiring modification of the SLLW Certification Program was the requirement to manage the disposal facility on the basis of the concentration of radionuclides in the waste rather than on the basis of the external radiation levels of the waste package. The management of SLLW on a concentration basis is reflected in a need for a more definitive characterization (i.e., which radionuclides and the quantities present) of the waste. To incorporate this higher level of stringency required in the characterization of the waste, the scope of the SLLW Certification Program is being expanded to include, in addition to the elements listed above, the following:

- establishment of a Waste Certification Group within the Waste Management Division, but independent of the Waste Operations Section, with the responsibility for the development, implementation, and oversight of the SLLWW Certification Program;

- development of WAC documents for the ORNL disposal facilities that mandate management of SLLW on a radionuclide concentration basis;

- establishment of a network of individuals (i.e., generator certification officials) within the generator organizations responsible for coordinating the implementation of the SLLW Program at the facility level;

- development of procedures at the generator level that identify the individual SLLW streams originating within the generator organization and the method(s) used by the generator for the characterization of the SLLW; and

- a more intensive monitoring of all SLLW certification activities.

\subsubsection{Future Direction}

With the centralization of Waste Management activities in 1993 into one organization, the Energy Systems Waste Management Organization (ESWMO), a similar restructuring and analysis of the approach to waste certification activities at ORNL is occurring. While the details and final direction in which the waste certification programs at Energy Systems will develop are continuing to evolve, some generic concepts or approaches have been developed. In general these include (but are not limited to) the following: 
- A defined program for the certification of radioactive, hazardous, and mixed wastes shall be established for such waste streams on the Oak Ridge Reservation.

- WAC shall be developed for all storage, treatment, and disposal facilities on the ORR. These WAC documents shall, to the extent practical, be written in a consistent format specified at the ESWMO level. WAC documents for the operation of SLLW disposal facilities shall contain radionuclide concentration limits that will be used to manage the facility source term on a real-time basis.

- Generators will be responsible for the development of Waste Certification Plans detailing the waste characterization methodologies, administrative controls, and generator training that will be instituted by the generator to produce wastes that can be demonstrated to be in compliance with WAC for storage, treatment, and disposal facilities.

- Generators will be responsible for characterizing their wastes and, upon transferring them to a storage, treatment, and disposal facility, certifying them as meeting WAC for storage, treatment, and disposal facilities.

- Generator waste certification programs shall pass an initial audit before approval to ship to a storage, treatment, and disposal facility is granted. Generators shall undergo periodic assessments against their certification plans to maintain their approved shipping status. The frequency of the assessments will depend on waste stream type, toxicity, and volume.

- Certification programs for TRU waste destined for WIPP and SLLW destined for the Nevada Test Site (or other DOE or commercial facilities) shall be established/maintained in a manner that complies with the requirements of that particular storage, treatment, and disposal facility.

\subsection{WASTE MANAGEMENT PLANNING ACTIVITIES}

\subsubsection{Strategic Planning}

ORNL, which originated in 1943 as part of the Manhattan Engineer District, currently focuses primarily on energy R\&D but also applies its expertise and facilities to other challenges that are important to DOE and the nation. The diversity of ORNL's R\&D activities and associated waste generation, coupled with an aging facility infrastructure, provides major challenges for effective waste management. The large legacy of stored wastes, contaminated sites, and surplus facilities left by historic endeavors, dating back in some cases to the Manhattan Engineer District, adds significantly to these challenges and requires close integration with environmental restoration activities, which also include decontamination and decommissioning.

The ORNL waste management mission is reduction, collection, treatment, storage, and disposal of DOE wastes, generated primarily in pursuit of ORNL missions, in order to protect human health and safety and the environment. In carrying out this mission, waste management staff in the Waste Management and Remedial Action Division (WMRAD) will (1) guide ORNL in optimizing waste reduction and waste management capabilities and (2) conduct waste management operations in a compliant, publicly acceptable, technically sound, and cost-efficient manner.

Through proactive planning, progressive programs, and sustained excellence in the performance of waste management functions, supported by cost-effective, cradle-to-grave technological systems, waste management activities will be, and will be recognized to be, state-of-the-art, conducted in compliance with all applicable laws, regulations, and agreements. This will be accomplished by maximal recycling and reuse of materials and 
facilities, development of disposal solutions for everything that is waste, and reduction of wastes and environmental discharges to the lowest levels possible.

\subsubsection{Long-Range Planning}

The purpose of the ORNL Waste Management Long-Range Plan (LRP) is to provide the comprehensive integrative link between several strategic and financial planning documents generated by WMRAD and the ESWMO. The LRP is intended (1) to be used by WMRAD strategic financial planners to support the development and preparation of Activity Data Sheets, Technical Description Documents, Activity-Based Cost Estimates, and Current Year Work Plans and (2) to provide the basis for risk-based priority planning. The LRP is also intended to be used as a concise reference by WMRAD upper level managers to ensure that (1) strategic issues have been properly identified and assigned appropriate priorities and (2) funding has been secured (or if funding has not been secured, that appropriate contingency planning has been effected).

The LRP establishes the strategic and financial planning baseline for the current routine operation of treatment, storage, and disposal systems/facilities for solid, liquid, and gaseous wastes generated at ORNL. Current and near-term issues affecting or potentially affecting routine operational strategies are identified, and the short-term strategies to be implemented for resolving them are outline. The primary focus of the LRP is to identify those long-term strategic issues that may potentially necessitate alterations to or significantly impact baseline operational strategies. The LRP provides the basis for and describes how those long-term strategic issues identified might impact baseline operational strategies. Most importantly, the LRP describes the present strategies for resolving those long-term strategic issues identified and determines if planning is complete, if funding is adequate, and if resources are available for successful implementation of the proposed strategies.

\subsection{DOCUMENT CONTROL}

The Document Management Center (DMC) maintains quality records for the ORNL Waste Management Operations Section (among others) by use of the Document Management System (DMS), which was conceived, designed, and configured by the DMC to meet DOE Order $5700.6 \mathrm{C}$ requirements for document control and quality records. The scope, requirements, and user guidelines of this quality assurance--based (QA) system operation are contained in the Documentation Management System Users Guide. The identification of documentation to be managed is the responsibility of the Waste Management Operations Section head, department heads, or their designee(s). These documents may be identified in a documentation plan and/or a QA Plan.

Following authorization of each project, program, or activity, a documentation plan may be generated by the responsible manager or his/her designee. Those documents to be generated are listed giving document sponsor, stage, document management livel, and retention period. Reviewers for procedures are determined on a case-by-case basis by the document review officer. Procedures must also be accompanied by a Review/Approval Form and a Distribution Control List.

Any document generated within the Waste Management Operations Section or generated in support of activities requested, coordinated, or managed by Waste Management Operations may be submitted to the DMC if accompanied by a completed Document Entry Request Form or a Document Change Request Form. DMS levels are described in Table 9.3. 
Table 9.3. Document Management System levels

\begin{tabular}{cl}
\hline Level & \multicolumn{1}{c}{ Description } \\
\hline 1 & $\begin{array}{l}\text { Records or documents that are managed for storage and retrieval } \\
\text { only }\end{array}$ \\
2 & $\begin{array}{l}\text { Document Management Center (DMC) distributed records or } \\
\text { documents whose review, approval, content, hand distribution, } \\
\text { retention, and storage, are strictly controlled according to } \\
\text { specified requirements for controlled documentation }\end{array}$ \\
$2.5 \quad \begin{array}{l}\text { DMC distributed records or documents whose review, approval, } \\
\text { content, mailed distribution, retention, and storage are strictly } \\
\text { controlled accoing to specified requirements for controlled } \\
\text { documentation }\end{array}$ \\
Records or documents that are managed for storage and limited \\
retrieval because information they contain may be sensitive; \\
retention is ensured and content protected \\
Records or documents that are managed for storage and retrieval \\
and for limited distribution to affected organizational personnel; \\
retention is ensured and content protected
\end{tabular}

When modifications or revisions are necessary or desirable in any documentation original maintained in the DMS, a Document Exchange Request Form (TX 5308) must be completed and approved. Also, when modifications are to be made to DMC-held original documentation, the modifications shall be made within or coordinated through the DMC.

Review and approval of modifications shall, except for procedures, be the same as for the document it supersedes. The original Document Entry Request Form is filed in the DMC and may be referred to as a guide. Also, management of revised documents should include the same distribution and document management level as the document it supersedes.

\subsection{QUALITY ASSURANCE}

The objective of the WMRAD QA Program is development, implementation, and maintenance of QA practices that will ensure that activities are (1) conducted with the highest regard and assurance for the health and safety of personnel and the surrounding population, (2) designed and executed for both short- and long-term protection of the environment, and (3) in compliance with the requirements of state and federal regulatory agencies as well as sponsors. Work is ongoing to bring programmatic elements of the division into compliance with American National Standards Institute and American Society of Mechanical Engineers NQA-1 QA standards and with other requirements mandated by DOE, Energy Systems, and ORNL.

A QA manual that provides procedures and instructions for implementing NQA-1 has been issued. The manual addresses elements of the NQA-1 standard and ensures that all requirements are met. A QA Evaluation is made of each project or activity, and projectspecific QA plans are developed, implemented, and overseen through a cooperative effort of division, line, and QA staff. Audit, review, inspection, and surveillance activities form an integral part of each project. QA training activities have been initiated and will continue for 
division personnel. The QA staff interfaces regularly with line personnel and division management at ORNL.

\subsection{NATIONAL ENVIRONMENTAL POLICY ACT COMPLIANCE AND DOCUMENTATION}

The National Environmental Policy Act (NEPA) was enacted as a national policy that would encourage harmony between man and his environment. Major points covered by the act are as follows:

- The federal government should use all practical means to ensure a safe environment and act as a trustee of the environment for future generations.

- The federal government should ensure that the widest range of beneficial uses of the environment is attained without degrading its quality. The environment, in this sense, includes cultural and historical as well as natural resources.

- The federal government should include in every proposal a detailed statement of its environmental impact and alternatives to it.

- The Council on Environmental Quality (CEQ) was created (1) to generate data on the conditions and trends on the quality of the environment, (2) to review federal government activities in light of those conditions and trends, and (3) to prepare an Environmental Quality Report annually for the president and Congress.

To implement this policy at ORNL, an environmental review and documentation program is maintained that is applicable to all ORNL facilities, programs, and operations as well as subcontractor activities or other work performed for or at ORNL under contractual arrangements. The following subsections provide examples of NEPA documentation.

\subsubsection{Action Description Memorandum}

An Action Description Memorandum (ADM) containing a concise written description of a proposed action and a brief discussion of relevant potential environmental issues is prepared for use in the DOE NEPA process to determine the appropriate level of NEPA documentation for a proposed action. It is prepared only for actions not listed in Subpart D of 10 CFR Pt. 1021.

\subsubsection{Environmental Assessment}

Defined in 40 CFR Pt. 1508.9, this document is prepared to assess whether a proposed action is a "major Federal action significantly affecting the quality of the human environment." It serves as the basis for a determination of whether an Environmental Impact Statement (EIS) is required. If an EIS is not considered necessary, a document called a Finding of No Significant Impact is prepared by DOE to record the DOE decision. 


\subsubsection{Environmental Impact Statement}

Defined in 40 CFR Pt. 1508.11, this document is prepared in accordance with the requirements of Sect. 102(2)(C) of NEPA as delineated by CEQ regulations and DOE guidance.

\subsubsection{Categorical Exclusion Determination}

This document is prepared to record a DOE decision that the action is categorically excluded and therefore does not require the preparation of an Environmental Assessment (EA) or an EIS.

\subsubsection{Finding of No Significant Impact}

Defined in 40 CFR Pt. 1508.15, this document is prepared to record a DOE decision that the environmental impacts of an action considered in an EA are not significant and that an EIS is not required for the proposed action.

\subsubsection{Record of Decision}

Prepared in accordance with the requirements of $40 \mathrm{CFR} \mathrm{Pt} .1505 .2$, this document provides a concise public record of DOE's decision on a proposed action for which an EIS was prepared. It identifies the alternatives considered in the related EIS, the environmentally preferable alternative, factors weighed in making the decision, and any mitigation or monitoring measures necessary to minimize adverse impacts.

\subsection{CLEAN WATER ACT DOCUMENTATION}

Documentation is also required to support Clean Water Act (CWA) compliance activities at ORNL. The following subsections provide examples of ORNL's CWA documentation.

\subsubsection{National Pollutant Discharge Elimination System Permit}

The TDEC issued a 1986 National Pollutant Discharge Elimination System (NPDES) permit to ORNL under the CWA allowing discharges of plant point sources including wastewater treatment facilities and plant storm water runoff. The permit sets limits on the types and amounts of pollutants that may be discharged. Violation of these permit limits constitutes noncompliance and is subject to legal action. Permit negotiations are under way for renewal of the NPDES permit and are expected to be final in 1994. 


\subsubsection{Best Management Practices Plan}

A Best Management Practices (BMP) Plan is a report required for submittal along with the NPDES permit application. BMP Plans are authorized under the $1977 \mathrm{CWA}$, as amended in 1987 by the Water Quality Act Amendments, for the control of nonroutine discharges from sources such as plant site runoff, spillage and leaks, sludge and waste disposal, drainage from material storage areas, and laboratory drains. Documentation of the effectiveness of the BMP Plans is one of the conditions under which the NPDES permit is issued.

\subsubsection{Activities Description Memorandum}

An Activities Description Memorandum (AcDM) is a written report documenting the environmental review of an existing facility or a planned or ongoing activity or operation (i.e., any action that does not involve construction). Like the ADM, the AcDM is a formal agreement document, which is required by the BMP Plan of ORNL's NPDES permit and becomes part of the permanent environmental record at ORNL. Unlike the ADM, the AcDM is not transmitted to DOE. AcDMs are made available for in-house use as well as for external State and U.S. Environmental Protection Agency audits. AcDMs provide documentation that the planned activity or operation does not have any environmental impact. 


\section{BIBLIOGRAPHY}

\section{DOE ORDERS}

U.S. DOE Feb. 24, 1981. Environmental Protection, Safety, and Health Protection Information Reporting Requirements, DOE Order 5484.1 in DOE Manual, Vol. 11.

U.S. DOE Aug. 13, 1981. Environmental Protection, Safety, and Health Protection Program for DOE Operations, DOE Order 5480.1A in DOE Manual, Vol. 11.

U.S. DOE May 3, 1982. Materials Transportation and Traffic Management, DOE Order 1540.1 in DOE Manual, Vol. 5.

U.S. DOE May 15, 1984. Environmental Protection, Safety, and Health Protection Standards, DOE Order 5480.4 in DOE Manual, Vol. 11.

U.S. DOE April 9, 1985. National Environmental Policy Act, DOE Order 5440.1C in DOE Manual, Vol. 11.

U.S. DOE July 9, 1985. Safety Requirements for the Packaging and Transportation of Hazardous Materials, Hazardous Substances, and Hazardous Wastes, DOE Order 5480.3 in DOE Manual, Vol. 11.

U.S. DOE Oct. 15, 1985. Uniform Reporting System, DOE Order 1332.1A in DOE Manual, Vol. 3.

U.S. DOE Sept. 23, 1986. Environment, Safety, and Health Program for U.S. Department of Energy Operations, DOE Order 5480.1B in DOE Manual, Vol. 11.

U.S. DOE March 6, 1987. Project Management System, DOE Order 4700.1 in DOE Manual, Vol. 10.

U.S. DOE July 11, 1987. Real Property and Site Development Planning, DOE Order 4300.1B in DOE Manual, Vol. 9.

U.S. DOE Sept. 26, 1988. Radioactive Waste Management, DOE Order 5820.2A in DOE Manual, Vol. 15.

U.S. DOE Dec. 19, 1988. Hazardous Material Packaging for Transport-Administrative Procedures, DOE Order 1540.2 in DOE Manual, Vol. 5.

U.S. DOE Dec. 21, 1988. Radiation Protection for Occupational Workers, DOE Order 5480.11 in DOE Manual, Vol. 11.

U.S. DOE Jan. 31, 1989. Environmental Compliance Issue Coordination, DOE Order 5400.2A in DOE Manual, Vol. 11.

U.S. DOE Nov. 22, 1989. Quality Assurance, DOE Order 5700.6B in DOE Manual, Vol. 15.

U.S. DOE June 5, 1990. Radiation Protection of the Public and the Environment, DOE Order 5400.5 in DOE Manual, Vol. 11.

U.S. DOE June 29, 1990. General Environmental Protection Program, DOE Order 5400.1 in DOE Manual, Vol. 11.

U.S. DOE Dec. 6, 1990. Comprehensive Environmental Response, Compensation, and Liability Act Requirements, DOE Notice 5400.4 in DOE Manual, Vol. 11.

U.S. DOE Feb. 22, 1991. Hazardous and Radioactive Mixed Waste Management Program, DOE Order 5400.3 in DOE Manual, Vol. 11.

U.S. DOE Aug. 21, 1991. Quality Assurance, DOE Order 5700.6C in DOE Manual, Vol. 18. 


\section{REPORTS AND INFORMATION SOURCES}

Ashwood, T. L. October 1990. Active Sites Environmental Monitoring Program: Program Plan, ORNL/M-1197, Martin Marietta Energy Systems, Oak Ridge Natl. Lab.

Baldwin, J. S. September 1989. Status Report-Strategic Planning and Facility Development for the Management of Oak Ridge National Laboratory Solid Low-Level and Special Case Radioactive Waste, ORNL/CF-89/298, Martin Marietta Energy Systems, Oak Ridge Natl. Lab.

Baldwin, J. S., et al. July 1988. Comprehensive Plan for Management of Hazardous and Mixed Waste at Oak Ridge National Laboratory, draft, ORNL/CF-89/224, Martin Marietta Energy Systems, Oak Ridge Natl. Lab.

Baldwin, J. S., et al. April 1989. Oak Ridge National Laboratory Implementation Plan for DOE Order 5820.2A, ORNL/TM-11166, Martin Marietta Energy Systems, Oak Ridge Natl. Lab.

Baldwin, J. S., et al. August 1989a. Oak Ridge National Laboratory Long-Range Environmental and Waste Management Plan: Program Overview and Summary, draft, ORNL-6536, Martin Marietta Energy Systems, Oak Ridge Natl. Lab.

Baldwin, J. S., et al. August 1989h. Oak Ridge National Laboratory Long-Range Environmental and Waste Management Plan: Detailed Management Plan, draft, ORNL-6537, Martin Marietta Energy Systems, Oak Ridge Natl. Lab.

Baldwin, J. S., et al. March 1990. Oak Ridge National Laboratory Transuranic Waste Management Strategy Plan, ORNL/TM-11506, Martin Marietta Energy Systems, Oak Ridge Natl. Lab.

Baldwin, J. S., Sease, J. D., and Jones, D. L. December 1989. Oak Ridge National Laboratory Waste Management Plan for Department of Energy Order 5820.2A, ORNL/TM-11433, Martin Marietta Energy Systems, Oak Ridge Natl. Lab.

Berry, J. B. June 1987. Environmental Restoration and Facilities Upgrade Program: Water Pollution Control Strategy, ORNL/TM-10343, Martin Marietta Energy Systems, Oak Ridge Natl. Lab.

Butterworth III, G. E., et a!. Dec. 16, 1988. Low-Level Waste Disposal Development and Demonstration Program FY 1989 Integrated Implementation Plan for the Oak Ridge Reservation Facilities, draft, ES/ESH-7, Martin Marietta Energy Systems, Oak Ridge Natl. Lab.

Dickerson, L. S. December 1988. Enginecring Analysis of the Oak Ridge National Laboratory Stack and Vent Survey, ORNL/CF-88/328, Martin Marietta Energy Systems, Oak Ridge Natl. Lab.

Environmental and Health Protection Division, Health and Safety Research Division, and Moreland, Inc., January 1990. The Spill Prevention, Control, Countermeasures, and Contingency Plans for Oak Ridge National Laboratory, Martin Marietta Energy Systems, Oak Ridge Natl. Lab.

Homan, M. D., Kendrick, C. M., and Schultz, R. M. March 199!. Waste Reduction Program at Oak Ridge National Laboratory During CY 1990, ORNL/TM-11780, Martin Marietta Energy Systems, Oak Ridge Natl. Lab.

Jones, L. S. and Vaughn, B. E. March 1991. Consolidated Waste Storage Plan, K/WM-2, Martin Marietta Energy Systems, Oak Ridge K-25 Site.

McNeese, L. E., et al. December 1988. Overall Strategy and Program Plan for Management of Radioactively Contaminated Liquid Wastes and Transuranic Sludges at the Oak Ridge National Laboratory, ORNL/TM-10757, Martin Marietta Energy Systems, Oak Ridge Natl. Lab. 
McNeese, L. E. July 12, 1991. Management Review Data Sheets for Environmental Projects, Martin Marietta Energy Systems, Oak Ridge Natl. Lab.

Oak Ridge National Laboratory February 1989. Hazardous Waste Development, Demonstration, and Disposal Plan, Martin Marietta Energy Systems.

Oak Ridge National Laboratory September 1990. Performance Assessment for Continuing and Future Operations at SWSA 6, draft, Martin Marietta Energy Systems.

Oak Ridge National Laboratory Jan. 10, 1991. Environmental Restoration Agreement for the Oak Ridge Reservation, draft, Martin Marietta Energy Systems.

Oak Ridge National Laboratory Mar. 1, 1991a. "Annual Report for Treatment, Storage, and Disposal Facilities," enclosure in Annual Hazardous Waste Report for the Department of Energy's Oak Ridge National Laboratory, Martin Marietta Energy Systems.

Oak Ridge National Laboratory Mar. 1, 1991b. "Annual Shipping Report for Hazardous Waste Generators," enclosure in Annual Hazardous Waste Report for the Department of Energy's Oak Ridge National Laboratory, Martin Marietta Energy Systems.

Oak Ridge National Laboratory Mar. 1, 1991c. "Hazardous Waste Generation Report," enclosure in Annual Hazardous Waste Report for the Department of Energy's Oak Ridge National Laboratory, Martin Marietta Energy Systems.

Oak Ridge National Laboratory May 24, 1991. Oak Ridge National Laboratory Corrective Action Plan in Response to Tiger Team Assessment, ORNL-6657, draft, rev. 4, Martin Marietta Energy Systems.

Oak Ridge National Laboratory December 1991. ES\&H Management Plan for Oak Ridge National Laboratory, Martin Marietta Energy Systems, Oak Ridge National Laboratory.

Oak Ridge National Laboratory. Environmental Analysis of the Operation of ORNL, Martin Marietta Energy Systems.

Oak Ridge National Laboratory. Environmental Surveillance of the ORR and Surrounding Environs During 1985, Martin Marietta Energy Systems.

Pudelek, R. E. June 1987. Environmental Restoration and Facilities Upgrade Program: Environmental Monitoring Strategy, ORNL/TM-10345, Martin Marietta Energy Systems, Oak Ridge Natl. Lab.

Robinson, S. M., DePaoli, S. M., and Walker, A. B. June 1991. Federal Facility Agreement Contingency, Upgrade, and Replacement Plans for the ORNL Active Low-Level Radioactive Waste Tank System, ORNL/TM-11795, Martin Marietta Energy Systems, Oak Ridge Natl. Lab.

Schultz, R. M. April 1990. Waste Reduction Plan for the Oak Ridge National Laboratory, ORNL/TM-11283, Martin Marietta Energy Systems, Oak Ridge Natl. Lab.

Science Application International Corporation September 1991. Environmental Restoration and Waste Management Site-Specific Plan for the Oak Ridge Operations Reservation, DOE/OR-968.

Sears, M. B., et al. September 1990. Sampling and Analysis of Radioactive Liquid Wastes and Sludges in the Melton Valley and Evaporator Facility Storage Tanks at ORNL, ORNL/TM-11652, Martin Marietta Energy Systems, Oak Ridge Natl. Lab.

Smith, J. H. September 1989. Status of Transuranic Waste Certification Program at the Oak Ridge National Laboratory, ORNL/CF-89/294, Martin Marietta Energy Systems, Oak Ridge Natl. Lab.

Smith, J. H., et al. August 1990. Oak Ridge National Laboratory Transuranic Certification Program, ORNL/TM-10322/R2, Martin Marietta Energy Systems, Oak Ridge Natl. Lab. 
Smith, J. H., Bates, L. D., and duMont, S. P. June 1987. Environmental Restoration and Facilities Upgrade Program: Solid Waste Management Strategy, ORNL/TM-10344, Martin Marietta Energy Systems, Oak Ridge Natl. Lab.

Smith, M. A. June 1991. Solid Low-Level Waste Certification Strategy, ORNL/TM-11307, Martin Marietta Energy Systems, Oak Ridge Natl. Lab.

Spalding, B. P., Jacobs, G. K., and Davis, E. C. September 1989. Demonstrations of Technology for Remediation and Closure of Oak Ridge National Laboratory Waste Disposal Sites, ORNL/TM-11286, Martin Marietta Energy Systems, Oak Ridge Natl. Lab.

Solomon, D. K., et al. 1992. Status Report-A Hydrologic Framework for the Oak Ridge Reservation, ORNL/TM-12026, Martin Marietta Energy Systems, Oak Ridge Natl. Lab.

Stewart, R. C., et al. June 1989. Remote-Handled Transuranic Solid Waste Characterization Study: Oak Ridge National Laboratory, ORNL/TM-11050, Martin Marietta Energy Systems, Oak Ridge Natl. Lab.

U.S. DOE July 1989. Environmental Assessment of the Shipment of Oak Ridge National Laboratory's Contact-Handled Transuranic Waste to the Waste Isolation Pilot Plant, DOE/EA-0349.

U.S. DOE January 1991. Environmental Regulatory Guide for Radiological Effluent Monitoring and Environmental Surveillance, DOE/EH-0173T.

U.S. DOE August 1991. Environmental Restoration and Waste Management Five-Year Plan, Fiscal Years 1993-1997, DOE/S-0090P.

U.S. DOE. DOE Environmental Restoration and Waste Management Five-Year Plan, Fiscal Years 1995-1999.

U.S. DOE Oak Ridge Operations Office-Martin Marietta Energy Systems Sept. 30, 1991. Strategic Roadmap for the Oak Ridge Reservation, predecisional draft.

U.S. DOE-Environmental Protection Agency, Region IV June 12 1992. Federal Facilities Compliance Agreement for Storage of Mixed Waste Subject to Land Disposal Restrictions for the Oak Ridge Reservation, docket 92-02 FFR.

U.S. Environmental Protection Agency, Region IV Mar. 27, 1986. Authorization to Discharge Under the National Pollutant Discharge Elimination System for Oak Ridge National Laboratory, Permit TN002941.

Lee Wan \& Associates April 1991. RCRA Closure Plan Revision for Solid Waste Storage Area 6, draft, Oak Ridge, Tenn.

Waste Management April 7, 1989. ORNL Hazardous Waste Operations Manual, WM-SWO-401, Martin Marietta Energy Systems, Oak Ridge Natl. Lab.

Waste Management May 16, 1990. Radioactive Solid Waste Operations Manual, WM-SWO-501, Martin Marietta Energy Systems, Oak Ridge Natl. Lab.

Waste Management January 1991. Solid Waste Certification Program Plan, K/WM-14, Martin Marietta Energy Systems, Oak Ridge National Laboratory.

Waste Management. Waste Management Operations Procedure, WM-DMC-101, Martin Marietta Energy Systems, Oak Ridge Natl. Lab.

Waste Management and Remedial Action Division December 1992. ORNL Waste Management Plan, ORNL/TM-11433/R2, Martin Marietta Energy Systems, Oak Ridge Natl. Lab.

Waste Management and Remedial Action Division and IT Corporation January 1993. Oak Ridge National Laboratory Waste Minimization/Reduction and Pollution Prevention Program Plan, TM-11853/R4, Martin Marietta Energy Systems, Oak Ridge National Laboratory. 
Waste Management and Remedial Action Division July 31, 1991. Documentation Management System Users Guide, WMRA-DMC-102, Martin Marietta Energy Systems, Oak Ridge Natl. Lab.

Waste Management and Remedial Action Division June 24, 1993. ORNL Waste Management Long-Range Plan, draft, Martin Marietta Energy Systems, Oak Ridge Natl. Lab.

Youngblood, E. L., and Scanlan, T. F. June 1987. Environmental Restoration and Facilities Upgrade Program: Air Pollution Control Program Strategy, ORNL/TM-10342, Martin Marietta Energy Systems, Oak Ridge Natl. Lab.

Youngblood, E. L., duMont, S. P., and Helms, R. E. August 1988. "Upgrade of the Radioactive Air Emission Systems at Oak Ridge National Laboratory," presented at the DOE/NRC Nuclear Air Cleaning Conference. 

DOE Order 5820.2A, Chapter II, Management of Transuranic Waste

(Underlining denotes updating of the original 1989 table)

\begin{tabular}{|c|c|c|c|c|c|c|c|}
\hline & \multirow{2}{*}{\multicolumn{2}{|c|}{ Requirement/Status }} & \multirow{2}{*}{ Current practice } & \multirow{2}{*}{ Current plans } & \multirow{2}{*}{$\begin{array}{l}\text { Completion } \\
\text { date }\end{array}$} & \multicolumn{2}{|c|}{ Estimated cost } \\
\hline & & & & & & Expense & Capital \\
\hline \multirow[t]{5}{*}{ a. } & \multicolumn{7}{|c|}{ Waste Classification } \\
\hline & (1) & Compliance & $\begin{array}{l}\text { Administrative and process controls are } \\
\text { used to segregate TRU waste at } \\
\text { generation. }{ }^{233} \mathrm{U},{ }^{244} \mathrm{Cm} \text {, and }{ }^{252} \mathrm{Cf} \text { are } \\
\text { managed as TRU waste at ORNL. }\end{array}$ & Continue current practice & NA & NA & NA \\
\hline & (2) & Partial Compliance & $\begin{array}{l}\text { TRU radionuclide concentration of } \\
\text { drummed } \mathrm{CH} \text { at the time of assay is } \\
\text { utilized. Container mass is not used to } \\
\text { calculate specific activity. ORNL does } \\
\text { not yet have the capability to assay } \\
\text { boxed } \mathrm{CH} \text { or RH TRU waste. }\end{array}$ & $\begin{array}{l}\text { Install box CH TRU assay system. } \\
\text { Include assay capabilities for RH TRU in } \\
\text { WHPP. See b.(1). }\end{array}$ & FY 2000 & $120 \mathrm{~K}$ & $1.5 \mathrm{M}$ \\
\hline & (3) & Partial Cơmpliance & See a.(2). & See a.(2). & & See a.(2). & \\
\hline & (4) & Partial Compliance & $\begin{array}{l}\text { Process flow sheets, materials lists, and } \\
\text { RTR provide data on hazardous } \\
\text { components that will be included in the } \\
\text { data package sent with the waste to } \\
\text { WIPP. }\end{array}$ & $\begin{array}{l}\text { RTR is being installed for CH TRU } \\
\text { boxes. RH TRU RCRA characterization } \\
\text { data will be generated at WHPP. } \\
\text { See a.(2). }\end{array}$ & FY 2000 & $70 \mathrm{~K}$ & $490 \mathrm{~K}$ \\
\hline \multirow[t]{5}{*}{ b. } & \multicolumn{7}{|c|}{ Waste Generation and Treatment } \\
\hline & (1) & Partial Compliance & $\begin{array}{l}\text { Technical and administrative controls and } \\
\text { generator training are utilized to reduce } \\
\text { waste generation. }\end{array}$ & $\begin{array}{l}\text { Expand TRU waste minimization focus. } \\
\text { Construct and operate WHPP for RH } \\
\text { TRU treatment, volume reduction, and } \\
\text { shipment. }\end{array}$ & FY 1994 & $\begin{array}{l}600 \mathrm{~K} \\
125 \mathrm{M}\end{array}$ & $\begin{array}{c}\text { NA } \\
300 \mathrm{M}\end{array}$ \\
\hline & (2) & Partial Compliance & See a. $(2-4)$ & See a. $(2-4)$ & & See a. $(2-4)$. & \\
\hline & (3) & Compliance & $\begin{array}{l}\text { Treatment of hazardous components is } \\
\text { not feasible; however, source reduction is } \\
\text { being implemented. }\end{array}$ & Continue current practice. & NA & NA & NA \\
\hline & (4) & NA & $\begin{array}{l}\text { ORNL does not generate TRU waste that } \\
\text { is classified for security reasons. }\end{array}$ & NA & NA & NA & NA \\
\hline
\end{tabular}


DOE Order 5820.2A, Chapter II (continued)

\begin{tabular}{llll}
\hline & & Estimated cost & Completion \\
\cline { 3 - 3 } & Current practice & Current plans & Capital \\
\hline
\end{tabular}

c. Waste Certification

(1) Partial Compliance

TRU waste is or will be certified according to the WIPP WAC, placed in interim storage, and eventually shipped to WIPP.

(2) Compliance

(3) Partial Compliance

(4) Partial Compliance

(5) Partial Compliance

(6) NA

(7) NA

(8) Partial Compliance

(9) Compliance

(10) NA

(11) Compliance
ORNL does not intend to send uncertified TRU waste to WIPP.

ORNL's NG CH TRU Certification Plan has been approved by WIPP WACCC. RH TRU plans have been reviewed by WIPP WACCC

Certification plans contain or will contain

See c.(3).

NA

NA

Generator's procedures are in place to implement the approved $\mathrm{CH}$ TRU Certification Plan.

Support will be provided to audit teams as required.

NA

Several findings were reported by the 1991 WIPP WACCC audit. All findings have been completed but remain open pending WIPP WACCC verification. controls to ensure adherence to plan.
Construct and operate facilities to

FY 2002 See b.(1) repackage RH TRU and certify $\mathrm{CH}$ and RH TRU waste and eventually ship to WIPP.

NA

$\begin{array}{ccc}\text { NA } & \text { NA } & \text { NA } \\ \text { FY 1994 } & 150 \mathrm{~K} & \text { NA }\end{array}$

Revise $\mathrm{CH}$ TRU certification documents to include stored waste and certification plans for transportation. Revise

certification for NG RH TRU and submit for WIPP WACCC approval.

See c.(3).

See c.(3).

NA

NA

Revise generator's procedures as needed to implement additional certification plans as approved.

NA
See c.(3).

See c.(3).

NA


DOE Order 5820.2A, Chapter II (continued)

\begin{tabular}{|c|c|c|c|c|c|}
\hline \multirow[b]{2}{*}{ Requirement/Status } & \multirow[b]{2}{*}{ Current practice } & \multirow[b]{2}{*}{ Current plans } & \multirow{2}{*}{$\begin{array}{c}\text { Completion } \\
\text { date }\end{array}$} & \multicolumn{2}{|c|}{ Estimated cost } \\
\hline & & & & Expense & Capital \\
\hline
\end{tabular}

d. Waste Packaging
(1) Partial Compliance
All NG CH TRU waste is packaged in noncombustible containers that meet DOT requirements.

(2) Partial Compliance

Some pressure relief devices have been utilized. NG $\mathrm{CH}$ TRU packages have HEPA filters in place prior to delivery to generator.

(3) Partial Compliance

All waste to be shipped to WIPP will be sealed, marked, and labeled in accordance with applicable requirements.

e. Temporary Storage at Generating Sites
(1) Partial Compliance
All CH TRU drums are clearly identified and physically segregated from LLW to the extent practical. RH TRU casks are separately stored.

(2) Partial Compliance

TRU and LLW containers are stored in the same buildings but are clearly distinguished.

(3) Compliance

(4) Partial Compliance

Access is controlled for current TRU storage facilities.

Limited monitoring is performed to detect releases.

(5) Compliance
Existing facilities constructed to appropriate design criteria and subjected to safety evaluations.
NG RH TRU waste will be repackaged in the WHPP. NG RH TRU will be

placed in improved storage casks.

Utilize pressure relief devices in repackaging of RH TRU and older $\mathrm{CH}$ TRU waste.

Generators will seal and Waste Management Operations will mark and label $\mathrm{CH}$ TRU containers. RH TRU sealing and labeling will be done at WHPP.

See a.(1)

See a.(1).

Provide upgraded RCRA-permitted FY 1997 See b.(1).

See b.(1).

See b.(1). storage facilities to meet requirements of the Order.

Access controls will be included as needed in new storage projects.

New storage facilities will provide improved monitoring capabilities.

New storage facilities will be designed, constructed, and operated to minimize potential for accidents.
See e.(2).

See e.(2).

See e.(2). 
DOE Order 5820.2A, Chapter II (continued)

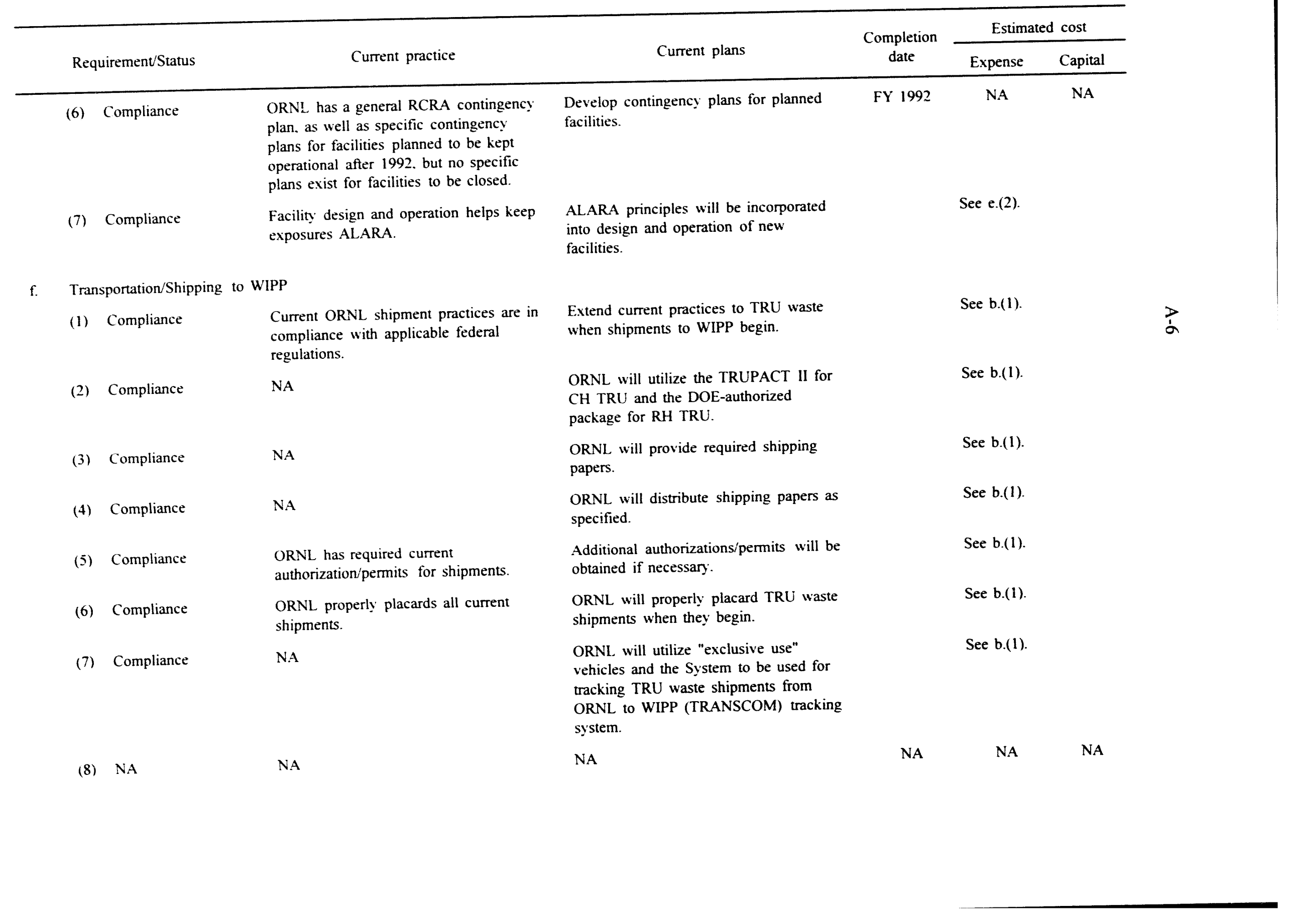


DOE Order 5820.2A, Chapter II (continued)

\begin{tabular}{llll}
\hline Requirement/Status & Current practice & Current plans & Completion \\
\cline { 3 - 3 } & & Capited & Expense \\
\hline
\end{tabular}

g. Interim Storage

(1) Partial Compliance

(2) Partial Compliance

(3) Noncompliance

(4) Compliance

(5) Partial Compliance

(6) Compliance

(7) Partial Compliance

(8) Partial Compliance
Current interim storage buildings are sufficient for current waste inventory but inadequate to meet projected needs.

Additional interim storage buildings are

being erected as required to meet the needs of SLLW storage.

RCRA permit applications have been prepared for two planned storage

facilities and two existing facilities.

Permit applications have been submitted for existing facilities meeting RCRA requirements. Existing facilities not meeting requirements will be closed

Current storage facilities protect the certification status of the waste.

Currently, ORNL is receiving TRU waste generated off-site.

See g.(5).

Currently, ORNL is receiving TRU waste generated off-site.

See g.(7).

Requirements $h(1-8)$ are applicable to

WIPP.
Construct new storage facilities.

See e.(2).

See e.(2)

Prepare RCRA permit applications for the remaining facilities. All permitted

facilities will be designed and operated in compliance with items $a-j$.

Close inadequate existing facilities

Construct new facilities. Permit existing

facilities that can be modified to meet

permit requirements.

Continue to store certified waste in such a manner that the certification is unaltered.

After WHPP becomes operational, store and process data packages from off-site generators and use them to prepare final data packages.

See g.(5).

Not all responsibilities outlined in this requirement will apply, since ORNL will not only store, but also repackage TRU

See g.(7).

\section{FY $1994 \quad 1 \mathrm{M}$}

See e.(2).

See e.(2)

See b.(1)

See b.(1).

2013 See b.(1) waste generated off-site.

See e.(2) and e.(6)

WIPP

(1-8) 
DOE Order 5820.2A, Chapter II (continued)

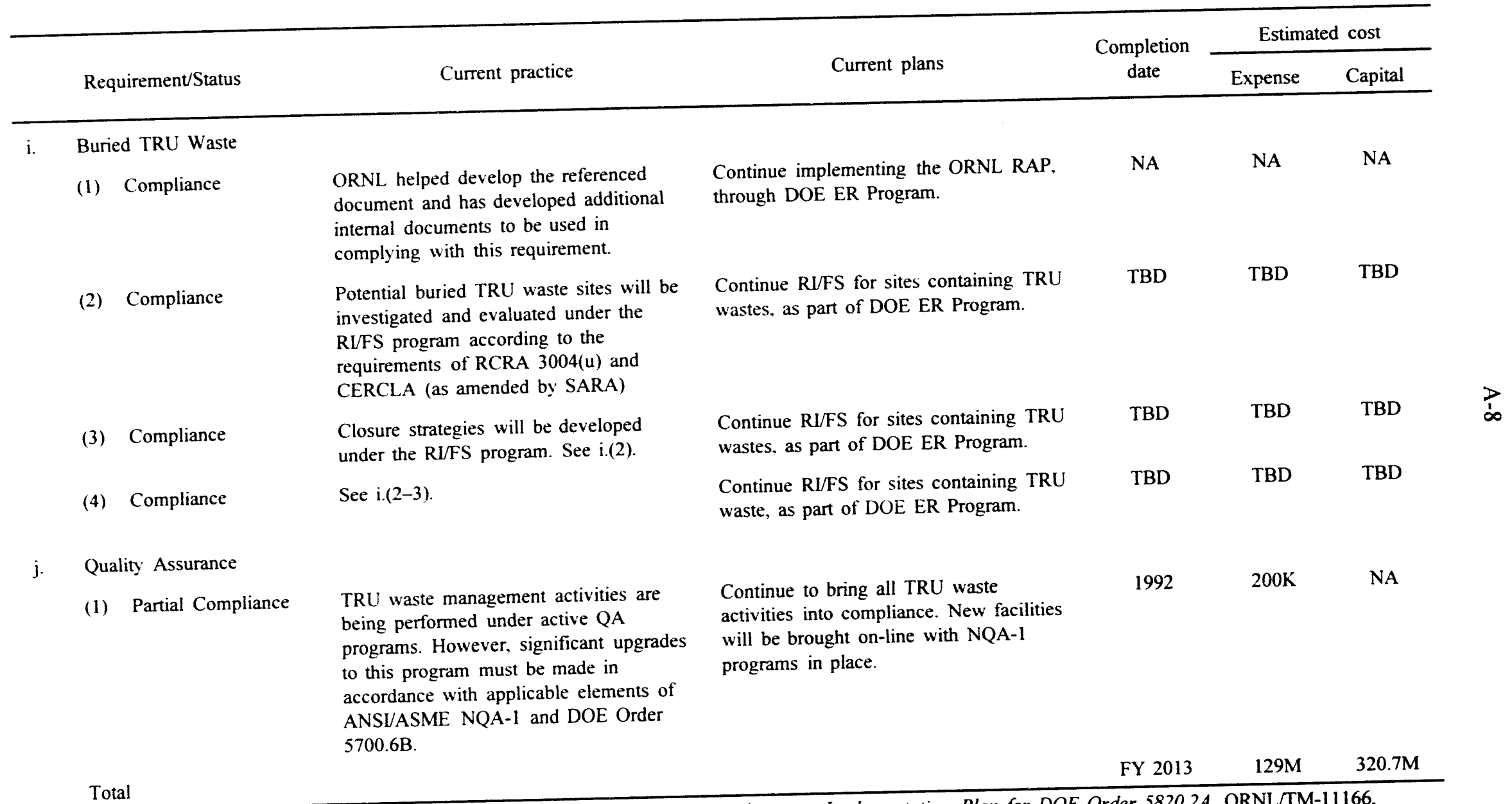

Source: Reprinted and updated from J. S. Baldwin et al.. Oak Ridge National Laboratory Implementation Plan for DOE Order 5820.2A, ORNL/TM-11166, Maurce: Reprinted and Marietta Energy Systems. Oak Ridge National Laboratory, April 1989. 


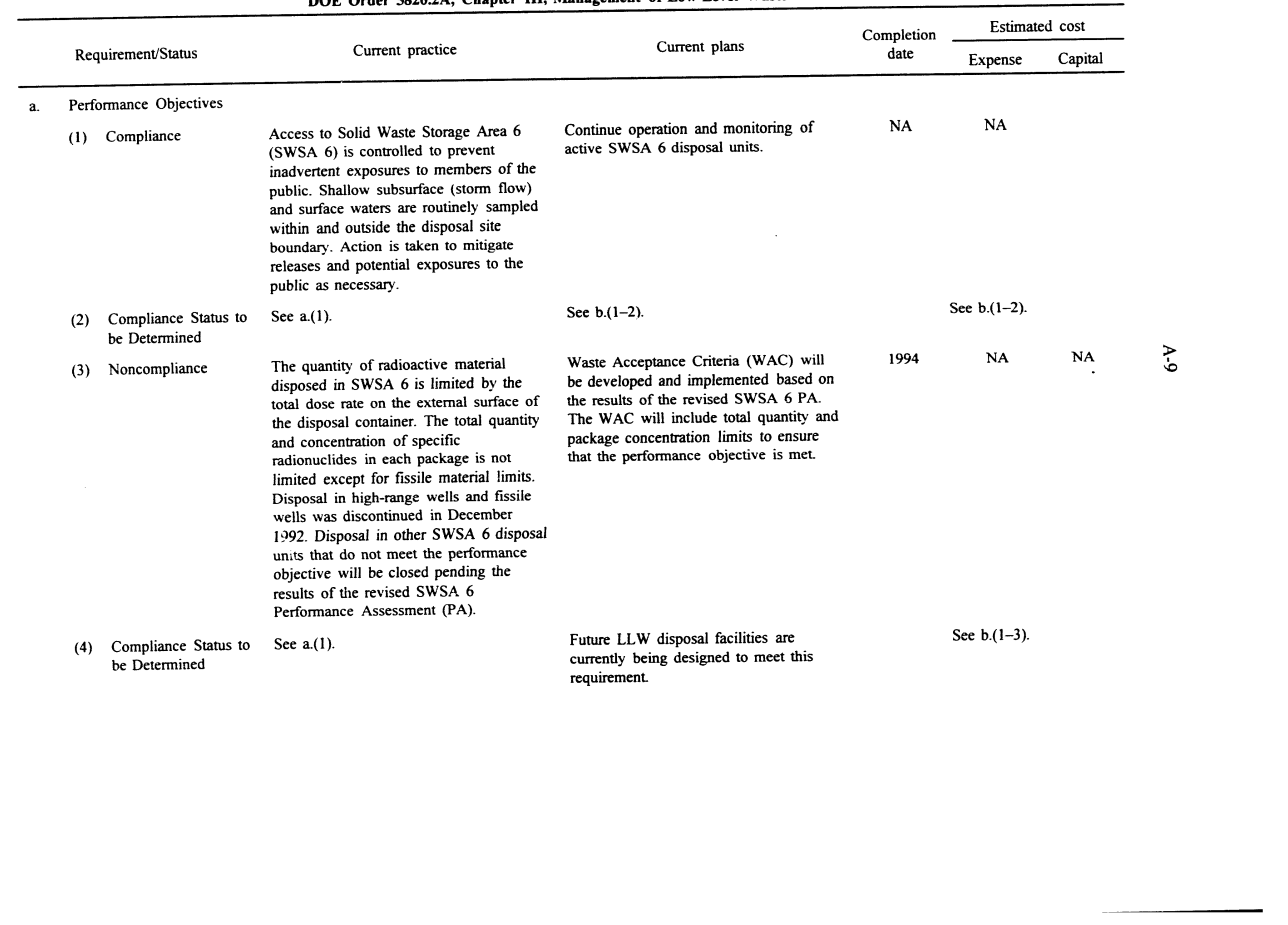


DOE Order 5820.2A, Chapter 111 (continued)

\begin{tabular}{|c|c|c|c|c|c|}
\hline \multirow[b]{2}{*}{ Requirement/Status } & \multirow[b]{2}{*}{ Current practice } & \multirow[b]{2}{*}{ Current plans } & \multirow{2}{*}{$\begin{array}{l}\text { Completion } \\
\text { date }\end{array}$} & \multicolumn{2}{|c|}{ Estimated cost } \\
\hline & & & & Expense & Capital \\
\hline
\end{tabular}

b. Performance Assessment

(1) Noncompliance

(2) Noncompliance

(3) Partial Compliance

c. Waste Generation

(1) Compliance

(2) Compliance

(3) Compliance
The SWSA 6 PA was submitted to DOEOak Ridge Operations (ORO) in

September 1990 for preliminary review: comments/recommendations were received from DOE Headquarers in May 1991; work on resolving DOE's

comments and completing the PA has been ongoing since July 1991 .

Oak Ridge National Laboratory has not conducted an overall waste management systems PA supporting the combination of waste management practices used in generation, reduction. segregation, treatment, packaging. storage, and disposal.

Monitoring of facility and disposal site performance is presently performed on a reconnaissance level.

Waste minimization program has been initiated.

Incentives are provided to generators to encourage waste reduction.

Some suspect waste generated.
Submit revised PA for review and approval to DOE-ORO

To be developed.

TBD

NA

To be determined after SWSA 6 PA is completed.

A waste minimization coordinator has been established for ORNL and program implementation is underway. The waste reduction plan for generators was revised in FY 1989 in accordance with DOE Order 5400.1. Additional emphasis will be given to LLW minimization at the source.

See c.(1).

Continue current practice. Suspect waste category to be eliminated.
See c.(1).

NA $\quad 500 \mathrm{~K} \quad \mathrm{NA}$
FY $1993 \quad 300 \mathrm{~K} \quad \mathrm{NA}$ 
DOE Order 5820.2A, Chapter III (continued)

\begin{tabular}{|c|c|c|c|c|c|c|c|}
\hline & \multirow{2}{*}{\multicolumn{2}{|c|}{ Requirement/Status }} & \multirow[b]{2}{*}{ Current practice } & \multirow{2}{*}{ Current plans } & \multirow{2}{*}{$\begin{array}{l}\text { Completion } \\
\text { date }\end{array}$} & \multicolumn{2}{|c|}{ Estimated cost } \\
\hline & & & & & & Expense & Capital \\
\hline & (4) & Compliance & $\begin{array}{l}\text { Waste Management Plans are required } \\
\text { for all new waste generating projects. } \\
\text { Waste reduction must be addressed in } \\
\text { this plan. Review of NEPA } \\
\text { documentation is performed for all new } \\
\text { projects to ensure that waste reduction } \\
\text { concerns are addressed. }\end{array}$ & See c.(1). & & See c.(1). & \\
\hline \multirow[t]{4}{*}{ d. } & \multicolumn{7}{|c|}{ Waste Characterization } \\
\hline & & Compliance & $\begin{array}{l}\text { Waste certification plans are required for } \\
\text { all generators. Generators are required on } \\
\text { these plans to identify what method(s) } \\
\text { will be used to characterize their waste. } \\
\text { Certification program relies heavily on } \\
\text { generator estimates and administrative or } \\
\text { process controls. }\end{array}$ & & FY 1994 & $1.5 \mathrm{M}$ & $2 \mathrm{M}$ \\
\hline & (2) & Compliance & $\begin{array}{l}\text { Waste manifests currently used contain } \\
\text { entries for characterization data cited in } \\
\text { this requirement. Radionuclide content is } \\
\text { reported as total curies/grams present per } \\
\text { package. }\end{array}$ & $\begin{array}{l}\text { Improve current practice and record } \\
\text { keeping procedures. }\end{array}$ & FY 1993 & $50 \mathrm{~K}$ & NA \\
\hline & (3) & Noncompliance & See $d(1)$. & $\begin{array}{l}\text { Demonstrations under way and planned } \\
\text { to assess applicability of direct and } \\
\text { indirect measurement techniques. }\end{array}$ & & See d.(1). & \\
\hline \multirow[t]{3}{*}{ e. } & \multicolumn{7}{|c|}{ Waste Acceptance Criteria } \\
\hline & & Compliance & $\begin{array}{l}\text { ORNL does not routinely receive LLW } \\
\text { from off-site nor does ORNL ship LLW } \\
\text { off-site for disposal at the present time. }\end{array}$ & $\begin{array}{l}\text { Future planning for shipment of waste } \\
\text { off-site will ensure compliance with this } \\
\text { requirement. }\end{array}$ & NA & NA & NA \\
\hline & (2) & Partial Compliance & $\begin{array}{l}\text { WAC have been established for existing } \\
\text { LLW TSD facilities. WAC has been } \\
\text { developed for IWMF and will need to be } \\
\text { revised when PA is issued. }\end{array}$ & $\begin{array}{l}\text { WAC for IWMF will be revised to } \\
\text { reflect the radionuclide concentration } \\
\text { limits from the SWSA } 6 \text { PA. }\end{array}$ & FY 1992 & $300 \mathrm{~K}$ & NA \\
\hline
\end{tabular}


DOE Order 5820.2A, Chapter III (continued)

\begin{tabular}{|c|c|c|c|c|c|c|c|}
\hline & \multirow{2}{*}{\multicolumn{2}{|c|}{ Requirement/Status }} & \multirow[b]{2}{*}{ Current practice } & \multirow{2}{*}{ Current plans } & \multirow{2}{*}{$\begin{array}{l}\text { Completion } \\
\text { date }\end{array}$} & \multicolumn{2}{|c|}{ Estimated cost } \\
\hline & & & & & & Expense & Capital \\
\hline & (3) & Compliance & $\begin{array}{l}\text { Certification program assures } \\
\text { conformance with current WAC through } \\
\text { administrative controls and NDANDE } \\
\text { techniques. }\end{array}$ & See d.(1). & & See d.(1). & \\
\hline & (4) & Compliance & $\begin{array}{l}\text { ORNL waste generators are subject to } \\
\text { routine audits from waste management } \\
\text { operations staff through the use of RTR } \\
\text { system, waste manifests approvals, and } \\
\text { periodic formal QA audits. }\end{array}$ & Continue current practice. & NA & NA & NA \\
\hline & (5) & Partial Compliance & $\begin{array}{l}\text { Concentrations will be determined by } \\
\text { radiological performance assessments } \\
\text { (see b.1). Hazards and Safety Analysis; } \\
\text { otherwise ORNL is in compliance with } \\
\text { this requirement. }\end{array}$ & $\begin{array}{l}\text { Phase in radionuclide concentration } \\
\text { WAC with operation of IWMF }\end{array}$ & FY 1994 & $50 \mathrm{~K}$ & See e.(2). \\
\hline \multirow[t]{5}{*}{ f. } & \multicolumn{2}{|c|}{ Waste Treatment } & & & & & \\
\hline & (1) & Compliance & $\begin{array}{l}\text { LLW is compacted to achieve volume } \\
\text { reduction and greater stability and } \\
\text { grouted to prevent contact with water and } \\
\text { to increase stability. }\end{array}$ & Implemented. & FY 1993 & NA & NA \\
\hline & (2) & Compliance & $\begin{array}{l}\text { Cement grouting, compaction, and super } \\
\text { compaction will be used to achieve waste } \\
\text { form stability and improve long-term } \\
\text { facility performance. }\end{array}$ & See $f .(1)$ & & See $f .(1)$. & \\
\hline & (3) & Compliance & $\begin{array}{l}\text { ORNL currently has no plans for } \\
\text { constructing large-scale waste treatment } \\
\text { facilities. }\end{array}$ & NA & NA & NA & NA \\
\hline & (4) & Partial Compliance & $\begin{array}{l}\text { See F.(1 and } 3) \text { and e.5 above. Before } \\
\text { any facility, handling LLW, is permitted } \\
\text { to initiate operation, required } \\
\text { documentation must be in place and } \\
\text { approved. }\end{array}$ & $\begin{array}{l}\text { Continue current practice as required. } \\
\text { Develop required documentation. }\end{array}$ & FY 1994 & $100 \mathrm{~K}$ & NA \\
\hline
\end{tabular}


DOE Order 5820.2A, Chapter III (continued)

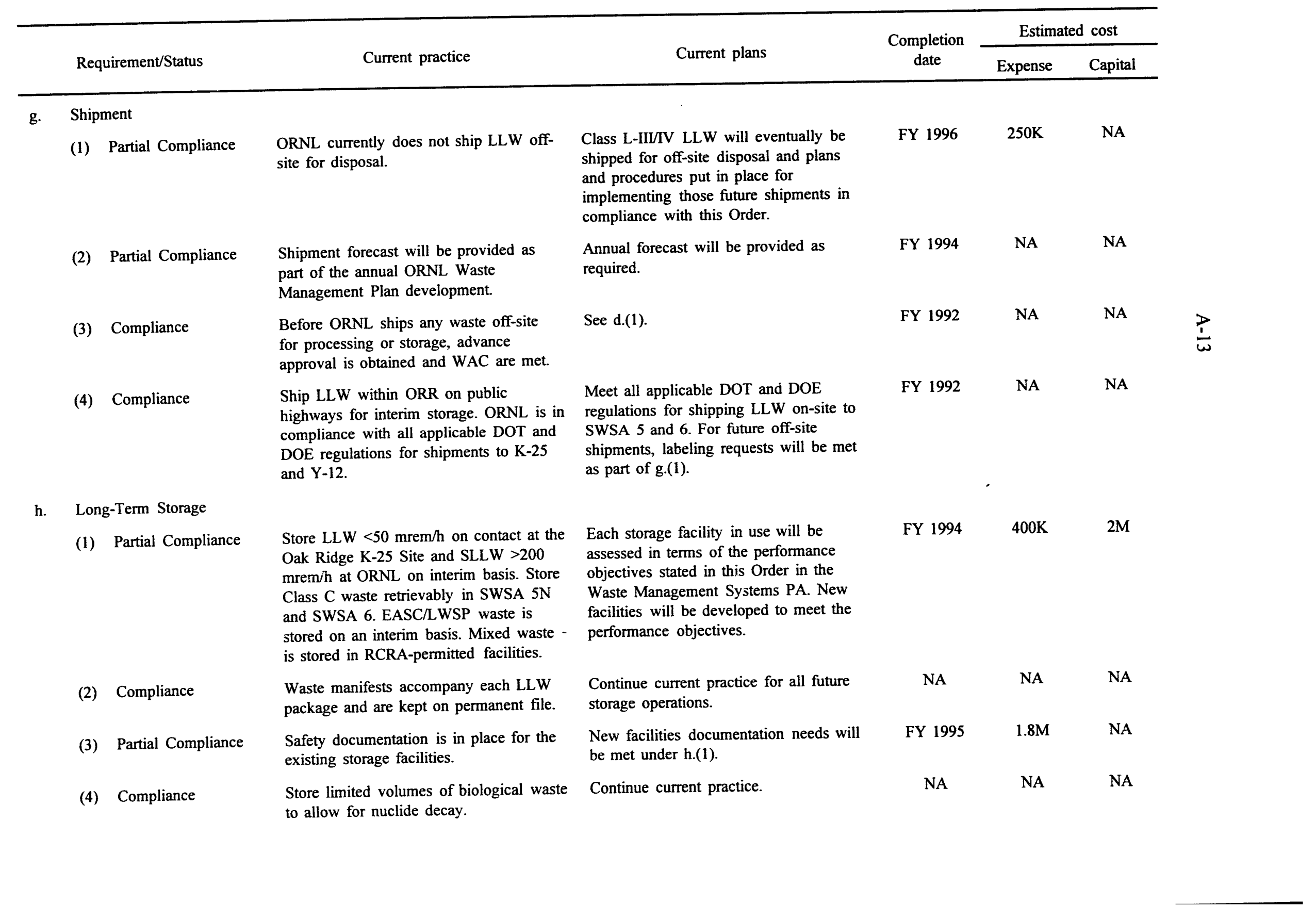


DOE Order 5820.2A, Chapter III (continued)

\begin{tabular}{llll}
\hline Requirement/Status & Estimated cost & Current plans & Completion \\
& Carrent practice & Expense & Capital
\end{tabular}

i. Disposal

(1) Compliance

(2) Partial Compliance

(3) Compliance

(4) Partial Compliance

(5) Compliance

(6) Handle waste below BRC limit as nonradioactive material

(7) Partial Compliance

(8) Compliance

(9) Partial Compliance
Dispose of LLW using above-grade and below-grade technologies. Draft PA indicates above-grade technology may achieve performance objectives; belowgrade doubtful.

Engineered GCD above- and below-grade technologies used for disposal of LLW.

ORNL has a representative on Oversight and Peer Review Panel.

Store greater-than-Class C waste on-site in retrievable stainless steel wells.

Additional disposal requirements are currently in practice.

BRC waste has not been officially defined by Federal regulations. Waste is classified as very low activity (VLA) waste.

The IWMF is being constructed in conformance with this requirement.

The IWMF is being constructed in conformance with this requirement.

Operation of disposal facilities are generally in compliance with this requirement, although improvements need to be made in administrative controls.
PAs will be conducted for each disposal

FY 1993

$750 \mathrm{~K}$

$2 \mathrm{M}$

technology currently in use or planned

for use in SWSA 6. New disposal

facilities will be developed and

implemented to meet the performance objectives.

LLW classification limits will be established for all LLW disposal facilities.

A performance assessment team has been formed which has the responsibility for conducting performance assessments for all DOE-OR sites.

Class L-III/IV Below-Grade Storage Facilities are planned for construction.

Requirements will be included in final WAC being developed under e.(2).

Continue to follow BRC status of regulations proposed by NRC

Began operation of IWMF.

Construct IWMF in accordance with this requirement.

Discontinue disposal of LLW in
FY 1993

FY 1996 $3.0 \mathrm{M}$

FY 1994

$200 \mathrm{~K}$

See e.(2).

FY 1994 See e.(2).
FY $1994 \quad 500 \mathrm{~K}$ procedures and training programs. 
DOE Order 5820.2A, Chapter III (continued)

\begin{tabular}{|c|c|c|c|c|c|c|c|}
\hline & & & \multirow{2}{*}{ Current practice } & \multirow{2}{*}{ Current plans } & \multirow{2}{*}{$\begin{array}{l}\text { Completion } \\
\text { date }\end{array}$} & \multicolumn{2}{|c|}{ Estimated cost } \\
\hline & \multicolumn{2}{|c|}{ Requirement/Status } & & & & Expense & Capital \\
\hline \multirow[t]{7}{*}{$\mathrm{j}$. } & \multicolumn{7}{|c|}{ Disposal Site Closure/Post Closure } \\
\hline & (1) & Partial Compliance & $\begin{array}{l}\text { Closure/post closure plans are being } \\
\text { developed for the active areas of } \\
\text { SWSA } 6 \text {, but not the Class II IWMF. }\end{array}$ & $\begin{array}{l}\text { Closure/post closure plans will be } \\
\text { developed for Class II IWMF. }\end{array}$ & FY 1996 & $250 \mathrm{~K}$ & NA \\
\hline & (2) & Partial Compliance & $\begin{array}{l}\text { Residual radioactivity levels are } \\
\text { considered in closure planning for } \\
\text { inactive portions of SWSA } 6 \text { and will be } \\
\text { considered for the rest of the site in } \\
\text { compliance with this requirement. }\end{array}$ & $\begin{array}{l}\text { Incorporate residual radioactivity } \\
\text { requirements in development of closure } \\
\text { plans under j.(1). }\end{array}$ & FY 1992 & \multicolumn{2}{|c|}{ See j.(1). } \\
\hline & (3) & Compliance & $\begin{array}{l}\text { Maintenance and surveillance, and } \\
\text { performance monitoring systems in place } \\
\text { to determine if corrective measures are } \\
\text { required for disposal sites or individual } \\
\text { units. Corrective actions for current GCD } \\
\text { silos have been implemented. }\end{array}$ & $\begin{array}{l}\text { Continue to implement corrective actions } \\
\text { for disposal units, as required. }\end{array}$ & Ongoing & $100 \mathrm{~K} / \mathrm{y}$ & NA \\
\hline & (4) & Compliance & $\begin{array}{l}\text { The EPA has elected to enforce } \\
\text { regulatory requirements for remedial } \\
\text { response activities to inactive disposal } \\
\text { facilities, sites, and units through } \\
\text { RCRA } 3004(\mathrm{u}) \text { and CERCLA (SARA). }\end{array}$ & $\begin{array}{l}\text { Inactive site closure and post-closure care } \\
\text { is provided through the DOE Energy } \\
\text { Research Program. }\end{array}$ & FY 1989 & NA & NA \\
\hline & (5) & Partial Compliance & $\begin{array}{l}\text { Existing protocol requires that all closure } \\
\text { plans for inactive, active, and new LLW } \\
\text { disposal facilities be reviewed by } \\
\text { DOE-ORO }\end{array}$ & Continue current practice. & FY 1996 & & (1). \\
\hline & (6) & Compliance & $\begin{array}{l}\text { This requirement will be included as part } \\
\text { of closure/post closure plans for existing } \\
\text { and new disposal sites and facilities. }\end{array}$ & Continue current practice. & & See j.(1). & \\
\hline
\end{tabular}


DOE Order 5820.2A, Chapter III (continued)

\begin{tabular}{llll} 
& & Estimated cost & Completion \\
\cline { 3 - 3 } & Current plans & Expense & Capital \\
\hline
\end{tabular}

k. Environmental Monitoring

(1) Partial Compliance

ORNL LLW TSD operational facilities have environmental monitoring programs that provide adequate control over environmental releases. Improvements to this program must be made, however, to conform to DOE Order 5484.1, k.(2-4) of this order, and the recently issued DOE Order 5400.1

(2) Partial Compliance

Majority of LLW TSD operational facilities have environmental programs that assess effluent releases, radionuclide migration, and changes affecting longterm performance.

(3) Partial Compliance

(4) Partial Compliance

1. Quality Assurance

(1) Partial Compliance

Preoperational monitoring determines operational monitoring requirements. on periodic basis.

Majority of LLW TSD operational facilities have environmental monitoring programs designed to detect significant changes that may compromise implemented.

LLW management activities are being
Entire environmental monitoring program

FY 1994

$2 \mathrm{M}$

$2 \mathrm{M}$ undergoing review. Will eventually come into compliance with DOE Order 5400.1 and requirements of this order.

See k.(1).

FY 1994

See k.(1).

FY 1994

See k.(1). Operational monitoring status reevaluated

performance so corrective actions may be performed under an active QA program. However, significant upgrades to this program must be made in accordance with applicable elements of ANSI/ASME NQA-1 and DOE Order 5700.6B.
Continue to bring all LLW waste management activities into compliance. New facilities will be brought on-line with NQA-1 QA programs in-place. 
DOE Order 5820.2A, Chapter III (continued)

\begin{tabular}{|c|c|c|c|c|c|c|c|}
\hline & \multirow{2}{*}{\multicolumn{2}{|c|}{ Requirement/Status }} & \multirow[b]{2}{*}{ Current practice } & \multirow{2}{*}{ Current plans } & \multirow{2}{*}{$\begin{array}{l}\text { Completion } \\
\text { date }\end{array}$} & \multicolumn{2}{|c|}{ Estimated cost } \\
\hline & & & & & & Expense & Capital \\
\hline \multirow[t]{4}{*}{$\mathrm{m}$} & Reco & rds and Reports & & & & & \\
\hline & (1) & Partial Compliance & $\begin{array}{l}\text { ORNL maintains a record keeping } \\
\text { system that documents waste was } \\
\text { properly classified, treated, stored, } \\
\text { shipped, or disposed of. }\end{array}$ & $\begin{array}{l}\text { Upgrade data system to increase } \\
\text { reliability and retrievability of data. }\end{array}$ & FY 1994 & $500 \mathrm{~K}$ & $400 \mathrm{~K}$ \\
\hline & (2) & Compliance & $\begin{array}{l}\text { Waste manifests accompany all waste } \\
\text { packages from initial generation to final } \\
\text { disposition and contain the information } \\
\text { necessary to determine adherence with } \\
\text { WAC for TSD activities. }\end{array}$ & Implemented & FY 1993 & See & (1). \\
\hline & Total & & & & & $13 \mathrm{M}$ & $11.4 \mathrm{M}$ \\
\hline
\end{tabular}

Source: Reprinted and updated from J. S. Baldwin et al., Oak Ridge National Laboratory Implementation Plan for DOE Order 5820.2A, ORNL/TM-11166, Martin Marietta Energy Systems, Oak Ridge National Laboratory, April 1989. 


\begin{tabular}{|c|c|c|c|c|c|}
\hline \multirow[b]{2}{*}{ Requirement/Status } & \multirow[b]{2}{*}{ Current practice } & \multirow[b]{2}{*}{ Current plans } & \multirow{2}{*}{$\begin{array}{l}\text { Completion } \\
\text { date }\end{array}$} & \multicolumn{2}{|c|}{ Estimated cost } \\
\hline & & & & Expense & Capital \\
\hline
\end{tabular}

a. General

(1) Partial compliance

(2) Compliance

(3) Partial Compliance

(4) Compliance

(6) Compliance

(7) Compliance
The D\&D Program maintains list of inactive contaminated facilities. Major radioactive operations maintained on file and reviewed by appropriate committees periodically.

Pertinent operational records for future use in preparing decommissioning plans are in permanent files.

Decontamination and decommissioning activities are taken into consideration for new facilities (see $b$. below). Existing facilities nearing shutdown are scrutinized very closely with respect to decontamination and decommissioning activities.

Inactive facilities have been identified and assigned a program sponsor.

Maintenance and surveillance and

decommissioning responsibilities have been assigned.

Responsibilities for contaminated facilities have been assigned specific programs through negotiation.

Facilities identified as DP, NE (Nuclear Energy), or ER are pending acceptance into appropriate programs.

ORNL provides information, as available, Continue current practices.

to update the decommissioning

technology data base Remedial Action

Program Information Center (RAPIC) as part of the ORNL D\&D Program.
Increasing emphasis will be given to

FY 1991

NA

NA

association of operational contaminated

facilities during periodic safety-related reviews.

Continue current practices.

NA

NA

NA

See a.(6) and b.

NA

NA

NA

Update specific program planning documents.

FY 1991

NA

NA

Maintenance and surveillance plans and decommissioning plans are updated periodically to reflect most recent changes in responsibility.

Pursue existing agreements and initiate new agreements. 
DOE Order 5820.2A, Chapter V (continued)

\begin{tabular}{|c|c|c|c|c|c|c|c|}
\hline & \multirow{2}{*}{\multicolumn{2}{|c|}{ Requirement/Status }} & \multirow{2}{*}{ Current practice } & \multirow{2}{*}{ Current plans } & \multirow{2}{*}{$\begin{array}{l}\text { Completion } \\
\text { date }\end{array}$} & \multicolumn{2}{|c|}{ Estimated cost } \\
\hline & & & & & & Expense & Capital \\
\hline \multirow[t]{2}{*}{ b. } & \multicolumn{7}{|c|}{ Facility Design } \\
\hline & & Compliance & $\begin{array}{l}\text { All new facilities at ORNL are designed } \\
\text { with decontamination and } \\
\text { decommissioning activities taken into } \\
\text { consideration. New facilities are designed } \\
\text { and constructed according to applicable } \\
\text { requirements of DOE } 6430.1\end{array}$ & Continue current practices. & NA & NA & NA \\
\hline \multirow[t]{3}{*}{ c. } & \multicolumn{7}{|c|}{ Post-Operational Activities } \\
\hline & & Compliance & $\begin{array}{l}\text { Methodologies and procedures are in } \\
\text { place for identifying contaminated } \\
\text { facilities and evaluating potential reuse or } \\
\text { recovery of real property. }\end{array}$ & Continue current practices. & NA & NA & NA \\
\hline & (2) & Compliance & $\begin{array}{l}\text { Inactive facilities are evaluated for } \\
\text { acceptance through set standards and } \\
\text { practices. Adequate maintenance and } \\
\text { surveillance is performed before } \\
\text { decontamination and decommissioning. }\end{array}$ & Continue current practices. & See a.(4). & $11.7 \mathrm{M}$ & See a.(4). \\
\hline \multirow[t]{4}{*}{ d. } & \multicolumn{7}{|c|}{ Decommissioning Project Activities } \\
\hline & & Partial Compliance & $\begin{array}{l}\text { ORNL collects characterization baseline } \\
\text { data to fulfill NEPA, RCRA, CERCLA, } \\
\text { SARA, and detailed engineering } \\
\text { requirements. }\end{array}$ & Continue current practices. & FY 2019 & $1800 \mathrm{M}$ & Inc. \\
\hline & (2) & Partial Compliance & $\begin{array}{l}\text { ORNL has submitted a RCRA Facility } \\
\text { Assessment (RFA) to proper federal } \\
\text { agencies. Conduct environmental reviews } \\
\text { when required. }\end{array}$ & See d.(1). & & See d.(1). & \\
\hline & (3) & Partial Compliance & $\begin{array}{l}\text { Decommissioning Project Plans are } \\
\text { prepared for approval by appropriate } \\
\text { program offices. }\end{array}$ & See d.(1). & & See d.(1). & \\
\hline
\end{tabular}


DOE Order 5820.2A, Chapter V (continued)

\begin{tabular}{|c|c|c|c|c|c|c|c|}
\hline & \multirow{2}{*}{\multicolumn{2}{|c|}{ Requirement/Status }} & \multirow[b]{2}{*}{ Current practice } & \multirow{2}{*}{ Current plans } & \multirow{2}{*}{$\begin{array}{l}\text { Completion } \\
\text { date }\end{array}$} & \multicolumn{2}{|c|}{ Estimated cost } \\
\hline & & & & & & Expense & Capital \\
\hline & (4) & Partial Compliance & $\begin{array}{l}\text { Facilities are decommissioned in } \\
\text { accordance with DOE-HQ guidance. } \\
\text { Proper approvals are obtained and status } \\
\text { reports submitted. }\end{array}$ & See d.(1). & & See d.(1). & \\
\hline & & Partial Compliance & $\begin{array}{l}\text { Final decommissioning reports are } \\
\text { prepared. Maintenance and surveillance is } \\
\text { supplied if required. project data } \\
\text { packages prepared. }\end{array}$ & See d.(1). & & See d.(1). & \\
\hline \multirow[t]{3}{*}{ e. } & \multicolumn{7}{|c|}{ Quality Assurance } \\
\hline & & Partial Compliance & $\begin{array}{l}\text { Decontamination and decommissioning } \\
\text { activities are conducted in accordance } \\
\text { with applicable elements of ANSVASME } \\
\text { NQA-1 and DOE Order } 5700.6 \mathrm{~B} \text {. }\end{array}$ & $\begin{array}{l}\text { Continue current practices. Project QA } \\
\text { costs are reflected in project budgets in } \\
\text { d.(1). }\end{array}$ & NA & NA & NA \\
\hline & \multicolumn{2}{|c|}{ Total } & & & & $255.7 \mathrm{M}$ & $10 \mathrm{M}$ \\
\hline
\end{tabular}

Source: Reprinted and updated from J. S. Baldwin et al.. Oak Ridge National Laboratory Implementation Plan for DOE Order 5820.2A, ORNL/TM-11166, Martin Marietta Energy Systems. Oak Ridge National Laboratory, April 1989. 


\section{WASTE MANAGEMENT DOCUMENTATION REQUIREMENTS}

\section{DISCUSSION}

This appendix addresses the principal documentation requirements as identified in DOE Order 5820.2A. The original appendix was provided in the ORNL Implementation Plan for DOE Order 5820.2A and will be updated annually and included in this ORNL Waste Management Plan. The format of the original appendix has been maintained for comparison purposes; revisions are denoted in the right-hand margin. Reporting is limited to documents issued in the previous fiscal year unless the most recent revision of an existing document was issued earlier.

\section{(1) Sect. 2.0-High-Level Waste}

Not applicable to ORNL.

\section{(2) Sect. 3.0-Transuranic Waste}

(a) Sect. 3.2.c.3. Cite the Transuranic Waste Certification Plan and dates of issue. If not issued, give schedule for preparation.

J. H. Smith et al., Oak Ridge National Laboratory Transuranic Waste Certification Program, ORNL/TM-10322/R2, August 1990.

M. W. Tull, Waste Acceptance Criteria for Transuranic Waste from Nuclear Fuel Services, Inc., WM-WMCO-202, January 21, 1991.

(b) Sects. 3.2.g and 3.2.h. Cite the closure plan for interim storage facilities. If not issued, give schedule for preparation.

RCRA Closure Plan, Transuranic Retrievable Drum Storage Facility, Building 7826, Oak Ridge National Laboratory (TN 1890090003), prepared by International Technology Corporation for Environmental Compliance and Documentation Section, Martin Marietta Energy Systems, Oak Ridge National Laboratory, September 1991.

RCRA Closure Plan, Transuranic Retrievable Drum Storage Facility, Building 7834, Oak Ridge National Laboratory (TN 1890090003), prepared by International Technology Corporation for Environmental Compliance and Documentation Section, Martin Marietta Energy Systems, Oak Ridge National Laboratory, September 1991.

Environmental Compliance and Health Protection Division, Part B RCRA Permit Application for Existing Remote-Handled Transuranic Concrete Cask Storage Facility, Building 7855 , Rev. 1, Martin Marietta Energy Systems, Oak Ridge National Laboratory, June 1989.

(c) Sect. 3.2.i. Index major documentation developed under the Buried TransuranicContaminated Waste Program. Show schedule for preparation of documents in the current fiscal year. 


\section{B-4}

J. R. Trabalka, Buried TRU Waste and TRU-Contaminated Soils and ORNL Remedial Action Program Sites; Program Strategy and Long-Range Planning, ORNL/RAP-8, July 1987.

Buried TRU Waste and TRU-Contaminated Soils at Oak Ridge National Laboratory, ORNL/RAP-24, September 1987.

\section{(3) Sect. 4.0-Low-Level Waste}

(a) Sect. 4.2.b.1. Cite documentation on radiological performance assessment of disposal facilities. If not issued, provide schedule for preparation in Sect. c. (3) of the Waste Management Plan.

Performance Assessment for Continuing and Future Operations at SWSA 6, draft, Martin Marietta Energy Systems, Oak Ridge National Laboratory, September 1990.

(b) Sect. 4.2.e.1. Cite Waste Acceptance Criteria for each LLW treatment, storage, and disposal facility. List anticipated additions to this list for the fiscal year.

Internal Correspondence, Warehousing of Wastes, W. R. Golliher, July 12, 1988, Attachment: Waste Acceptance Criteria for Storage, (K-25 Building)

Waste Acceptance Criteria for Radioactive Solid Waste Disposal at SWSA 6, WM-WMCO-203, July 1, 1991.

(c) Sect. 4.2.e.3. Report the status of audits of certification activities by operators of disposal facilities. Report status of follow-up reports.

M. W. Tull, et al., Oak Ridge National Laboratory Waste Certification Program Plan for Solid Low-Level Radioactive Waste, draft, ORNL/TM-11600, August 1990.

(d) Sect. 4.2.g.2. List document(s) forecasting waste to be shipped by generators to off-site disposal facilities.

No documents were prepared this fiscal year.

(e) Sect. 4.2.i.4. List reports justifying on-site disposal of waste exceeding Class $\mathrm{C}$ limits. Such disposal cases anticipated for the next year should be forecast.

No GTCC waste was disposed at ORNL this fiscal year.

(f) Sect. 4.2.i.8. Cite major NEPA documentation supporting sclection of any new disposal sites. Give schedule of preparation for appropriate documentation for the next year.

A preliminary draft EIS was prepared by NUS Corporation for DOE-ORO. This document was issued for comment in October 1993. It addresses waste management activities on the ORR. The draft EIS includes siting of proposed new LLW facilities.

(g) Sect. 4.2.j.1. Cite closure plans for LLW disposal sites and dates of issue. Give schedule of preparation for anticipated reports. 


\section{B-5}

Closure Plan Revision for Solid Waste Storage Area 6, draft, Lee Wan \& Associates, Inc., April 1991.

\section{(4) Sect. 6.0-Decommissioning of Radioactively Contaminated Facilities}

(a) Sect. 6.2.a.1. Cite field organization documentation where the complete listing and the jurisdictional program responsibility for all contaminated facilities is recorded.

T. W. Burwinkle, et al., Maintenance and Surveillance Plan for the ORNL Surplus Facilities Management Program and Defense Facilities Decommissioning Program FY 1990-1999, ORNL/RAP-51, January 1989.

Memorandum, Troy E. Wade II to Theodore J. Garrish, James F. Decker, and Joe La Grone; Subject: Approval of Memorandum of Agreement Concerning Management of ORNL Remedial Action Program, dated May 16, 1988.

(b) Sect. 6.2.c.1. Cite the post-operational documentation that records the potential for reuse and recovery of materials and equipment and the schedule for decommissioning contaminated facilities.

T. W. Burwinkle et al., The ORNL Surplus Facilities Management Program Long-Range Plan Revision 1, ORNL/TM-8957/R1, draft, June 1987.

(c) Sect. 6.2.d.3 List Decommissioning Project Plans and date of issue. Show schedule for preparation of plans in the current fiscal year.

T. E. Myrick, R.W. Schaich and J. R. DeVore, Metal Recovery Facility Decommissioning Project Plan-April 1984, ORNL/TM-9018, April 1984.

T. E. Myrick, R. W. Schaich and F. W. Williams, Fission Product Development Laboratory Cell Decommissioning Project Plan-August 1983, ORNL/TM-8779, August 1983.

Storage Garden (3033) Decommissioning Project Plan, December 1990.

Metal Recovery Facility Cell G Decontamination Project Plan, December 1991.

(d) Sect. 6.2.d.5. List final radiological and chemical survey reports and project final reports, and show dates of issue. Show anticipated additions to this list for the coming year.

R. W. Schaich, Final Report on the Decontamination of the Curium Fabrication Facility, ORNL/TM-8276, December 1983.

3033 Storage Garden Decommissioning Project: Final Report, ORNL/ER/INT-3, May 1990. 

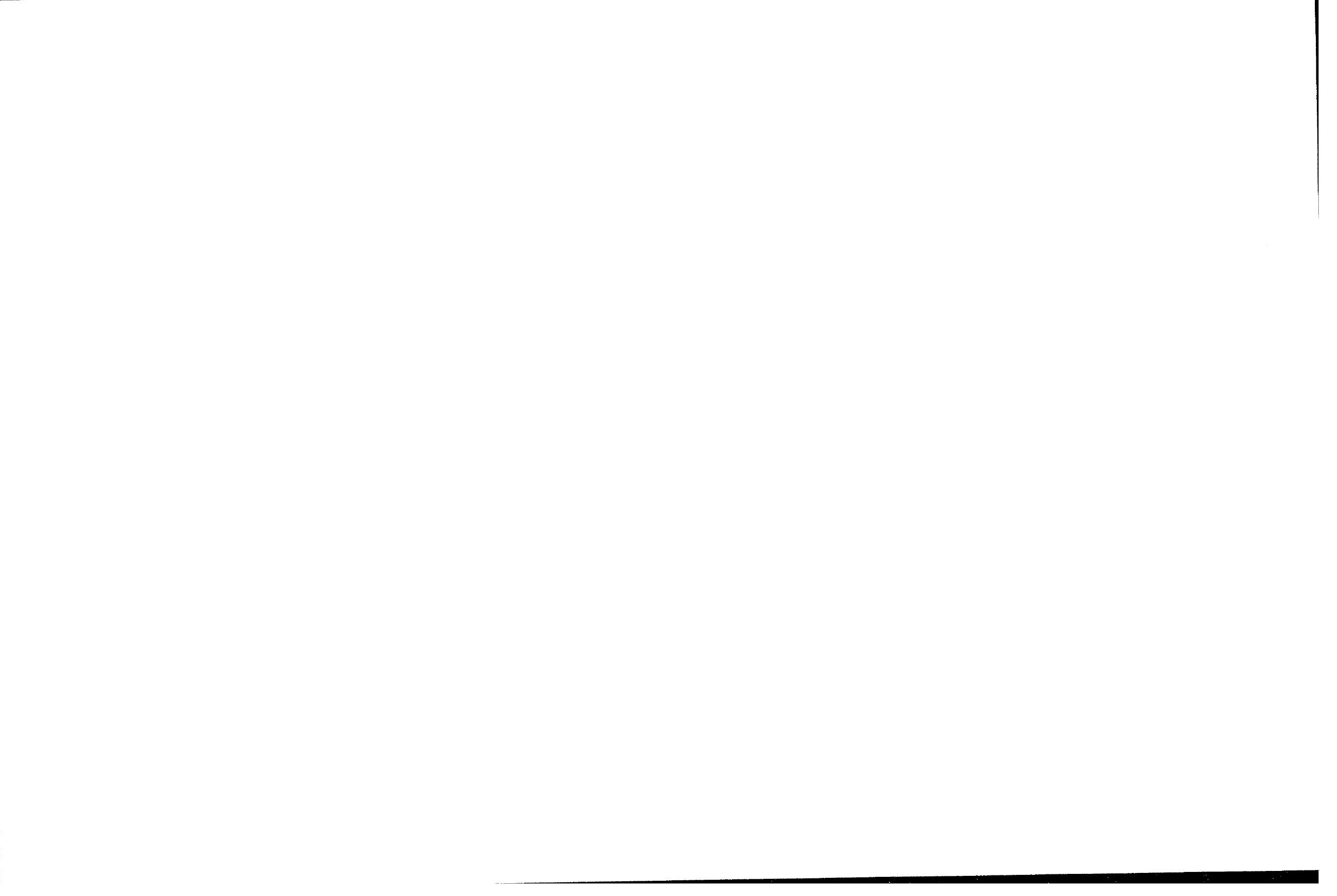

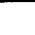


Current operational status of Oak Ridge National Laboratory waste treatment, storage, and disposal facilities

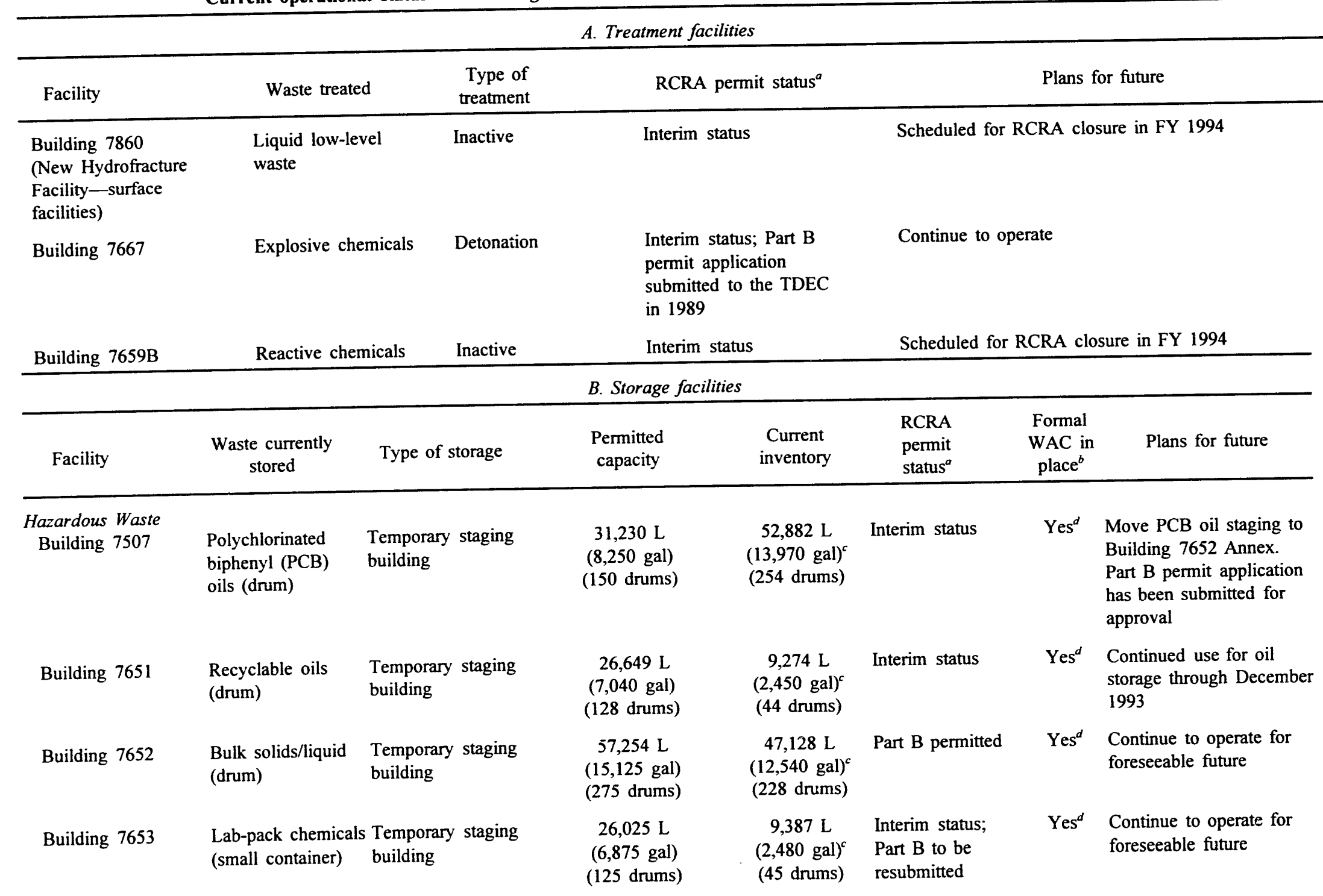


Current operational status of Oak Ridge National Laboratory waste treatment, storage, and disposal facilities (continued)

\begin{tabular}{|c|c|c|c|c|c|c|c|}
\hline \multicolumn{8}{|c|}{ B. Storage facilities } \\
\hline Facility & $\begin{array}{l}\text { Waste currently } \\
\text { stored }\end{array}$ & Type of storage & $\begin{array}{l}\text { Permitted } \\
\text { capacity }\end{array}$ & $\begin{array}{l}\text { Current } \\
\text { inventory }\end{array}$ & $\begin{array}{l}\text { RCRA } \\
\text { permit } \\
\text { status }^{a}\end{array}$ & $\begin{array}{l}\text { Formal } \\
\text { WAC in } \\
\text { place }^{b}\end{array}$ & Plans for future \\
\hline Building 7934 & $\begin{array}{l}\text { Spent photographic } \\
\text { solution (drum) }\end{array}$ & $\begin{array}{l}\text { Temporary staging } \\
\text { building }\end{array}$ & $\begin{array}{c}56,781 \mathrm{~L} \\
(15,000 \mathrm{gal}) \\
(273 \text { drums })\end{array}$ & $\begin{array}{c}54,094 \mathrm{~L} \\
(14,290 \mathrm{gal})^{c} \\
(260 \text { drums })\end{array}$ & $\begin{array}{l}\text { Currently exempt- } \\
\text { recycle materials; } \\
\text { will be added to } \\
\text { Part A for interim } \\
\text { status }\end{array}$ & Yes $^{c}$ & $\begin{array}{l}\text { Part B permit application } \\
\text { has been submitted for } \\
\text { approval }\end{array}$ \\
\hline $\begin{array}{l}\text { Mixed Waste } \\
\text { Building } 7507 \mathrm{~W}\end{array}$ & $\begin{array}{l}\text { Mixed solids/ } \\
\text { liquids (drums) }\end{array}$ & $\begin{array}{l}\text { Long-term covered } \\
\text { pad }\end{array}$ & $\begin{array}{c}83,279 \mathrm{~L} \\
(22,000 \mathrm{gal}) \\
(400 \text { drums })\end{array}$ & $\begin{array}{c}76,087 \mathrm{~L} \\
(20,100 \mathrm{gal}) \\
(365 \text { drums })\end{array}$ & Interim status & $\mathrm{Yes}^{d}$ & $\begin{array}{l}\text { Part B permit application } \\
\text { has been submitted for } \\
\text { approval }\end{array}$ \\
\hline Building 7654 & $\begin{array}{l}\text { Mixed solids/ } \\
\text { liquids (drum) }\end{array}$ & Long-term building & $\begin{array}{c}72,8 \leqslant 0 \mathrm{~L} \\
(19,250 \mathrm{gal}) \\
(350 \text { drumis })\end{array}$ & $\begin{array}{c}52,996 \mathrm{~L} \\
(14,000 \mathrm{gal}) \\
(255 \text { drums })\end{array}$ & $\begin{array}{l}\text { Interim status;Part } \\
\text { B resubmitted }\end{array}$ & Yes $^{d}$ & $\begin{array}{l}\text { Part B permit application } \\
\text { has been submitted for } \\
\text { approval }\end{array}$ \\
\hline Building 7823 & $\begin{array}{l}\text { Mixed solids/ } \\
\text { liquids (drum) }\end{array}$ & Long-term building & $\begin{array}{c}840 \mathrm{~m}^{3} \\
\left(30,000 \mathrm{ft}^{3}\right)\end{array}$ & $\begin{array}{c}68,081 \mathrm{~L} \\
(17,985 \mathrm{gal}) \\
(327 \text { drums })\end{array}$ & $\begin{array}{l}\text { Interim status; } \\
\text { Part B submitted }\end{array}$ & Yes $^{d}$ & Continued storage \\
\hline Tank 7075 & Mixed oils & Long-term tank & $\begin{array}{c}15,899 \mathrm{~L} \\
(4,200 \text { gal })\end{array}$ & $\begin{array}{c}15,899 \mathrm{~L} \\
(4,200 \mathrm{gal})^{c}\end{array}$ & Interim status & Yes $^{d}$ & $\begin{array}{l}\text { Closing activities in } \\
\text { progress }\end{array}$ \\
\hline Tank 7830a & Mixed oils & Long-term tank & $\begin{array}{c}18,927 \mathrm{~L} \\
(5,000 \mathrm{gal})\end{array}$ & $\begin{array}{c}18,927 \mathrm{~L} \\
(5,000 \mathrm{gal})^{c}\end{array}$ & $\begin{array}{l}\text { Interim status: } \\
\text { Part B submitted }\end{array}$ & Yes $^{d}$ & Will be permitted \\
\hline $\begin{array}{l}\text { Solid low-level waste } \\
7823 \mathrm{~B}\end{array}$ & Drums (LLW) & Long-term building & $\begin{array}{l}510 \text { drums } \\
108 \mathrm{~m}^{3} \\
\left(3,825 \mathrm{ft}^{3}\right)\end{array}$ & $\begin{array}{l}510 \text { drums } \\
108 \mathrm{~m}^{3} \\
\left(3,825 \mathrm{ft}^{3}\right)\end{array}$ & $\mathrm{NA}$ & No & Continued storage \\
\hline $7823 \mathrm{C}$ & Drums (LLW) & Long-term building & $\begin{array}{l}528 \text { drums } \\
112 \mathrm{~m}^{3} \\
\left(3,960 \mathrm{ft}^{3}\right)\end{array}$ & $\begin{array}{l}528 \text { drums } \\
112 \mathrm{~m}^{3} \\
\left(3,960 \mathrm{ft}^{3}\right)\end{array}$ & $\mathrm{N}_{A}$ & No & Continued storage \\
\hline
\end{tabular}


Current operational status of Oak Ridge National Laboratory waste treatment, storage, and disposal facilities (continued)

\begin{tabular}{|c|c|c|c|c|c|c|c|}
\hline \multicolumn{8}{|c|}{ B. Storage facilities } \\
\hline Facility & $\begin{array}{l}\text { Waste currently } \\
\text { stored }\end{array}$ & Type of storage & $\begin{array}{l}\text { Permitted } \\
\text { capacity }\end{array}$ & $\begin{array}{l}\text { Current } \\
\text { inventory }\end{array}$ & $\begin{array}{l}\text { RCRA } \\
\text { permit } \\
\text { status }\end{array}$ & $\begin{array}{l}\text { Formal } \\
\text { WAC in } \\
\text { place }^{b}\end{array}$ & Plans for future \\
\hline $7823 \mathrm{D}$ & Drums (LLW) & Long-term building & $\begin{array}{l}480 \text { drums } \\
102 \mathrm{~m}^{3} \\
\left(3,600 \mathrm{ft}^{3}\right)\end{array}$ & $\begin{array}{l}480 \text { drums } \\
102 \mathrm{~m}^{3} \\
\left(3,600 \mathrm{ft}^{3}\right)\end{array}$ & NA & No & Continued storage \\
\hline $7823 \mathrm{E}$ & Drums (LLW) & Long-term building & $\begin{array}{l}1,000 \text { drums } \\
212 \mathrm{~m}^{3} \\
\left(7,500 \mathrm{ft}^{3}\right)\end{array}$ & $\begin{array}{l}211 \text { drums } \\
45 \mathrm{~m}^{3} \\
\left(1,582 \mathrm{ft}^{3}\right)\end{array}$ & NA & No & Continued storage \\
\hline 7856 & $\begin{array}{l}\text { Casks (solidified } \\
\text { LLLW) }\end{array}$ & Long-term pad & $\begin{array}{c}160 \text { casks } \\
838 \mathrm{~m}^{3} \\
\left(29,600 \mathrm{ft}^{3}\right)\end{array}$ & $\begin{array}{c}121 \text { casks } \\
634 \mathrm{~m}^{3} \\
\left(22,385 \mathrm{ft}^{3}\right)\end{array}$ & NA & No & Continued storage \\
\hline LWSP II & $\begin{array}{l}\text { Casks (solidified } \\
\text { LLLW) }\end{array}$ & Long-term pad & $\begin{array}{c}100 \text { casks } \\
524 \mathrm{~m}^{3} \\
\left(18,500 \mathrm{ft}^{3}\right)\end{array}$ & 0 casks & NA & No & Begin storage in FY 1994 \\
\hline $7878 \mathrm{~A}$ & Drums and boxes & Long-term building & $\begin{array}{l}600 \text { boxes } \\
1,700 \mathrm{~m}^{3} \\
\left(60,000 \mathrm{ft}^{3}\right)\end{array}$ & & NA & No & $\begin{array}{l}\text { Begin storage in } 1993 \text {; } \\
\text { continue to operate for } \\
\text { foreseeable future }\end{array}$ \\
\hline Building 7879 & $\begin{array}{l}\text { Solid low-level } \\
\text { waste (SLLW) } \\
\text { (drum/box) }\end{array}$ & $\begin{array}{l}\text { Temporary staging } \\
\text { building }\end{array}$ & $\begin{array}{c}560 \mathrm{~m}^{3} \\
\left(20,000 \mathrm{ft}^{3}\right)\end{array}$ & $\mathrm{NA}^{c}$ & Part B submitted & Yes $^{f . g}$ & $\begin{array}{l}\text { Continue to operate for } \\
\text { foreseeable future }\end{array}$ \\
\hline $7823 \mathrm{~A}$ & Spent nuclear fuel & $\begin{array}{l}8 \text { stainless steel } \\
\text { wells }\end{array}$ & & $\begin{array}{c}1.2 \mathrm{~m}^{3} \\
\left(43 \mathrm{ft}^{3}\right) \\
\text { full }\end{array}$ & No & No & $\begin{array}{l}\text { Continue to store waste } \\
\text { until DOE develops } \\
\text { policy for disposing of } \\
\text { spent nuclear fuel }\end{array}$ \\
\hline 7827 & $\begin{array}{l}\text { Spent nuclear } \\
\text { fuel, sealed } \\
\text { sources, and } \\
\text { other irradiated } \\
\text { material }\end{array}$ & $\begin{array}{l}54 \text { stainless steel } \\
\text { wells }\end{array}$ & & $\begin{array}{c}6.5 \mathrm{~m}^{3} \\
\left(234 \mathrm{ft}^{3}\right)\end{array}$ & No & No & $\begin{array}{l}\text { Continue to store waste } \\
\text { until DOE develops a } \\
\text { policy for disposing of } \\
\text { spent nuclear fuel and } \\
\text { other special case waste }\end{array}$ \\
\hline
\end{tabular}


Current operational status of Oak Ridge National Laboratory waste treatment, storage, and disposal facilities (continued)

\begin{tabular}{|c|c|c|c|c|c|c|c|}
\hline \multicolumn{8}{|c|}{ B. Storage facilities } \\
\hline Facility & $\begin{array}{l}\text { Waste currently } \\
\text { stored }\end{array}$ & Type of storage & $\begin{array}{l}\text { Permitted } \\
\text { capacity }\end{array}$ & $\begin{array}{l}\text { Current } \\
\text { inventory }\end{array}$ & $\begin{array}{l}\text { RCRA } \\
\text { permit } \\
\text { status }^{a}\end{array}$ & $\begin{array}{l}\text { Formal } \\
\text { WAC in } \\
\text { place }^{b}\end{array}$ & Plans for future \\
\hline 7829 & Spent nuclear fuel & $\begin{array}{l}10 \text { stainless steel } \\
\text { wells }\end{array}$ & & $\begin{array}{l}1.1 \mathrm{~m}^{3} \\
\left(40 \mathrm{ft}^{3}\right)\end{array}$ & No & No & $\begin{array}{l}\text { Continue to store waste } \\
\text { until DOE develops } \\
\text { policy for disposing of } \\
\text { spent nuclear fuel }\end{array}$ \\
\hline K-25 Site & $\begin{array}{l}\text { SLLW (drum/box) } \\
\text { Lab-pack chemicals }\end{array}$ & Long-term building & $h$ & $\begin{array}{c}875 \mathrm{~m}^{3} \\
\left(31,250 \mathrm{ft}^{3}\right)\end{array}$ & NA & Yes & $\begin{array}{l}\text { Continue to use K-25 Site } \\
\text { storage for Process Waste } \\
\text { Treatment Plant sludges } \\
\text { and boxed, compactible } \\
\text { waste }\end{array}$ \\
\hline $\begin{array}{c}\text { Solid TRU Waste } \\
\text { Building } 7879\end{array}$ & $\begin{array}{l}\text { Solid contact- } \\
\text { handled transuranic } \\
\text { (CH TRU) } \\
\text { (drum/box) }\end{array}$ & $\begin{array}{l}\text { Temporary staging } \\
\text { building }\end{array}$ & $\begin{array}{c}560 \mathrm{~m}^{3} \\
\left(20.000 \mathrm{ft}^{3}\right)\end{array}$ & $\begin{array}{c}260 \mathrm{~m}^{3} \\
\left(9,189 \mathrm{ft}^{3}\right)\end{array}$ & $\begin{array}{l}\text { Interim status;Part } \\
\text { B submitted }\end{array}$ & Yes $^{d . g}$ & $\begin{array}{l}\text { Continue to operate for } \\
\text { foreseeable future }\end{array}$ \\
\hline $\begin{array}{l}\text { Buildings } 7826 \\
\text { and } 7834\end{array}$ & $\begin{array}{l}\text { Solid CH TRU } \\
\text { (drum/box) }\end{array}$ & $\begin{array}{l}\text { Long-term } \\
\text { underground cells }\end{array}$ & $\begin{array}{c}716 \mathrm{~m}^{3} \\
\left(25,574 \mathrm{ft}^{3}\right)\end{array}$ & $\begin{array}{c}437 \mathrm{~m}^{3} \\
\left(15,443 \mathrm{ft}^{3}\right)\end{array}$ & Interim status & $\mathrm{Yes}^{g}$ & $\begin{array}{l}\text { Initiate closure by } \\
\text { November } 8,1992 ; \\
\text { closure to be completed } \\
\text { in FY } 1994\end{array}$ \\
\hline Building 7855 & $\begin{array}{l}\text { Solid remote- } \\
\text { handled }(\mathrm{RH}) \\
\text { TRU }\end{array}$ & $\begin{array}{l}\text { Long-term } \\
\text { underground bunker }\end{array}$ & $\begin{array}{c}175 \mathrm{~m}^{3} \\
\left(6.234 \mathrm{ft}^{3}\right) \\
(108 \text { casks })\end{array}$ & $\begin{array}{c}155 \mathrm{~m}^{3} \\
\left(5.541 \mathrm{ft}^{3}\right) \\
(96 \text { casks })\end{array}$ & $\begin{array}{l}\text { Part B } \\
\text { permitted }\end{array}$ & $\mathrm{Yes}^{d, f}$ & $\begin{array}{l}\text { Continue long-term } \\
\text { storage until the Waste } \\
\text { Handiling and Packaging } \\
\text { Plant begins processing } \\
\text { RH TRU in FY } 1999 \\
\text { along with ultimate } \\
\text { shipment to WIPP }\end{array}$ \\
\hline $\begin{array}{l}\text { Solid Waste } \\
\text { Storage Area } \\
5 \mathrm{~N} \text { trenches }\end{array}$ & Solid RH TRU & Long-term trench & $\begin{array}{c}84 \mathrm{~m}^{3} \\
\left(3,000 \mathrm{ft}^{3}\right)\end{array}$ & $\begin{array}{c}84 \mathrm{~m}^{3} \\
\left(3.000 \mathrm{ft}^{3}\right)\end{array}$ & Interim status & No & $\begin{array}{l}\text { Remove from Part A } \\
\text { permit and close under } \\
\text { CERCLA }\end{array}$ \\
\hline
\end{tabular}

$(7802 \mathrm{~N})$ 
Current operational status of Oak Ridge National Laboratory waste treatment, storage, and disposal facilities (continued)

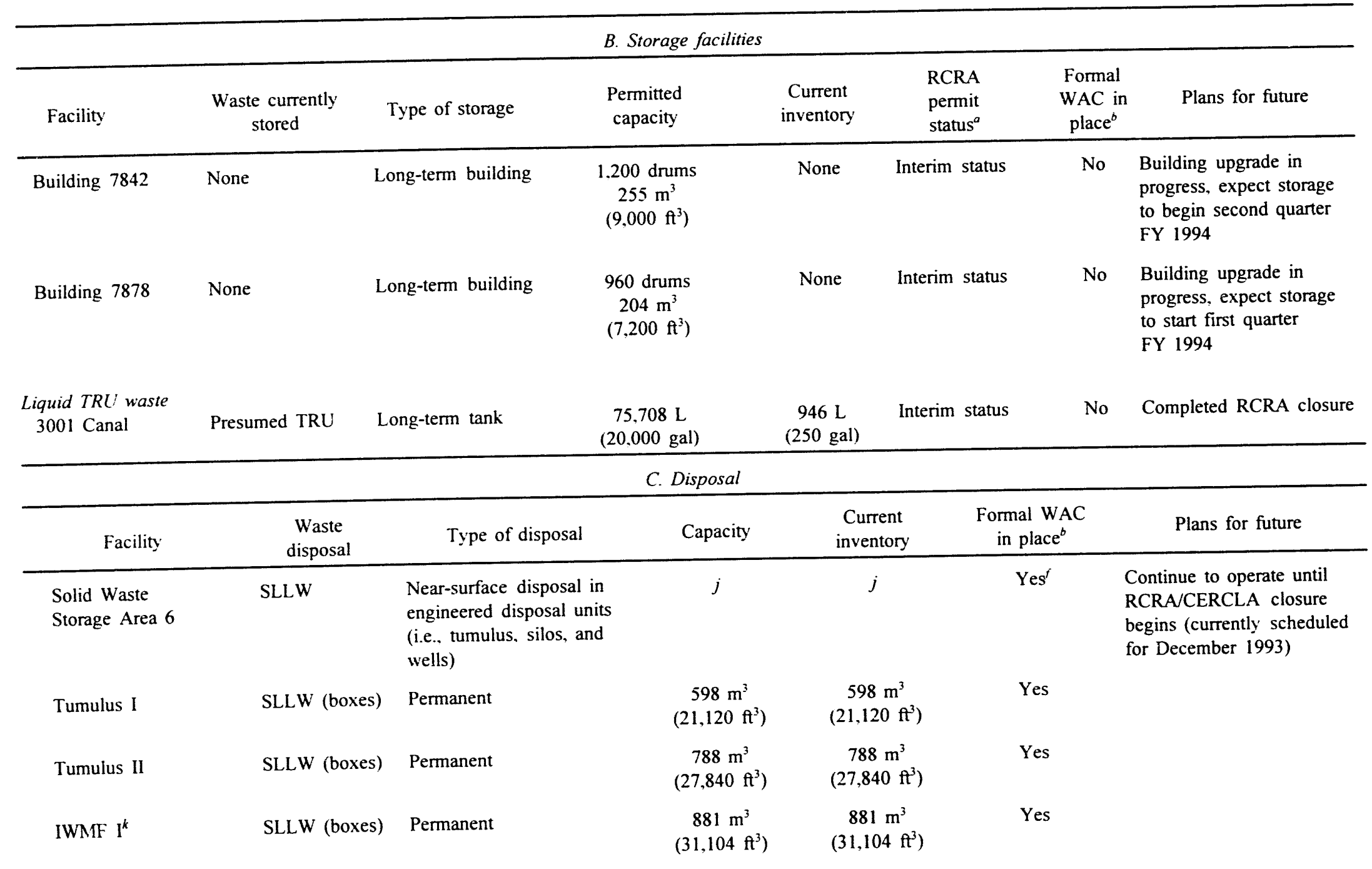


Current operational status of Oak Ridge National Laboratory waste treatment, storage, and disposal facilities (continued)

\begin{tabular}{|c|c|c|c|c|c|c|}
\hline \multicolumn{7}{|c|}{ C. Disposal } \\
\hline Facility & $\begin{array}{c}\text { Waste } \\
\text { disposal }\end{array}$ & Type of disposal & Capacity & $\begin{array}{c}\text { Current } \\
\text { inventory }\end{array}$ & $\begin{array}{c}\text { Formal WAC } \\
\text { in place }\end{array}$ & Plans for future \\
\hline IWMF II & SLLW (boxes) & Permanent & $\begin{array}{c}897 \mathrm{~m}^{3} \\
\left(31,680 \mathrm{ft}^{3}\right) \\
(330 \text { vaults })\end{array}$ & $\begin{array}{c}533 \mathrm{~m}^{3} \\
\left(18,818 \mathrm{ft}^{3}\right) \\
(196 \text { vaults })\end{array}$ & Yes & \\
\hline LWSP $\mathrm{II}^{\prime}$ & $\begin{array}{l}\text { Concrete } \\
\text { casks }\end{array}$ & Temporary & $>100$ casks & 0 & Yes & \\
\hline $\begin{array}{l}\text { Solid Waste } \\
\text { Storage Area } 7\end{array}$ & SLLW & Tumulus & $j$ & $j$ & & $\begin{array}{l}\text { Site under development; } \\
\text { operational start date in } \\
2000\end{array}$ \\
\hline
\end{tabular}

${ }^{a}$ Resource Conservation and Recovery Act.

${ }^{b}$ Waste acceptance criteria.

Inventory varies by month. current inventory as of October 1993

Included in RCRA Part A or B permit application.

'Plans may change after the EPA issues used oil regulations.

ORNL Health Physics Manual. Martin Marietta Energy Systems, Oak Ridge National Laboratory, Aug. $21,1991$.

ORNL Health Phystication Program. ORNL/TM-10322/R2. Martin Marietta Energy Systems, Oak Ridge National Laboratory, August 1990.

${ }^{h}$ Capacity full until new areas are prepared and placed in service.

'Comprehensive Environmental Response, Compensation, and Liability Act.

Not determined.

${ }^{k}$ Interim Waste Management Facility.

'Liquid Waste Solidification Project. 


\section{INTERNAL DISTRIBUTION}

1. T. J. Abraham

2. P. E. Arakawa

3. J. S. Baldwin

4. H. M. Braunstein

5. T. W. Burwinkle

6. P. J. Campbell

7. J. A. Chapman

8. A. D. Clay

9. D. E. Coffey

10. G. R. Cunningham

11. N. S. Dailey

12. S. M. Depaoli

13-27. D. L. Daugherty

28. K. G. Edgemon

29. D. M. Ferren

30. M. K. Ford

31. J. R. Forgy, Jr.

32. A. F. Frederick

33. C. E. Frye

34. H. R. Gaddis

35. S. B. Garland III

36. J. K. Gilpin

37-39. D. F. Hall

40. H. Hall

41. L. V. Hamilton

42. F. R. Hodges

43. J. H. Hooyman

44. S. C. Howard

45. R. J. Hydzik

46. L. S. Jones

47. C. M. Kendrick

48. T. E. Kent

49. F. C. Kornegay

50. J. P. Lankford

51. N. J. Lowe

52. J. J. Maddox

53. C. A. Manrod

54. R. C. Mason
55. B. C. McClelland

56. L. E. McNeese

57. J. E. Meador

58. L. J. Mezga

59. S. R. Michaud

60. M. E. Mitchell

61. J. B. Murphy

62. C. E. Nix

63. R. C. Orrin

64. J. R. Parott, Jr.

65-79. R. E. Pudelek

80. S. H. Reece

81. S. M. Robinson

82. P. H. Roush

83. S. T. Rudell

84 85. T. F. Scanlan

86. F. J. Schultz

87. C. B. Scott

88. B. V. Shelton

89. L. R. Simmons

90. R. C. Stewart

91-92. L. E. Stratton

93. J. H. Swanks

94. F. J. Sweeney

95. J. R. Trabalka

96-100. M. W. Tull

101. D. W. Turner

102-103. J. W. Turner

104. S. D. Van Hoesen

105. D. M. Wasserman

106. L. C. Wesley

107. C. Whitmire, Jr.

108. W. C. Yee

109. ORNL Patent Office

110. Central Research Library, ORNL

111. K-25 Library

112. Y-12 Technical Division Library

113-114. ORNL Laboratory Records

115. ORNL Laboratory Records-RC

\section{EXTERNAL DISTRIBUTION}

116. W. M. Belvin, Laboratory Operations Branch, U.S. Department of Energy, Oak Ridge Operations Office, P.O. Box 2001, Oak Ridge, Tennessee 37831

117. H. W. Hibbits, Environmental Protection Division, U.S. Department of Energy, Oak Ridge Operations Office, P.O. Box 2001, Oak Ridge, Tennessee 37831-8738

118-120. D. R. Underwood, U.S. Department of Energy, Oak Ridge Operations Office, Waste Management Division, P.O. Box 2001, Oak Ridge, Tennessee 37831-8620.

121-122. Office of Scientific and Technical Information, U.S. Department of Energy, P.O. Box 62, Oak Ridge, Tennessee 37831. 

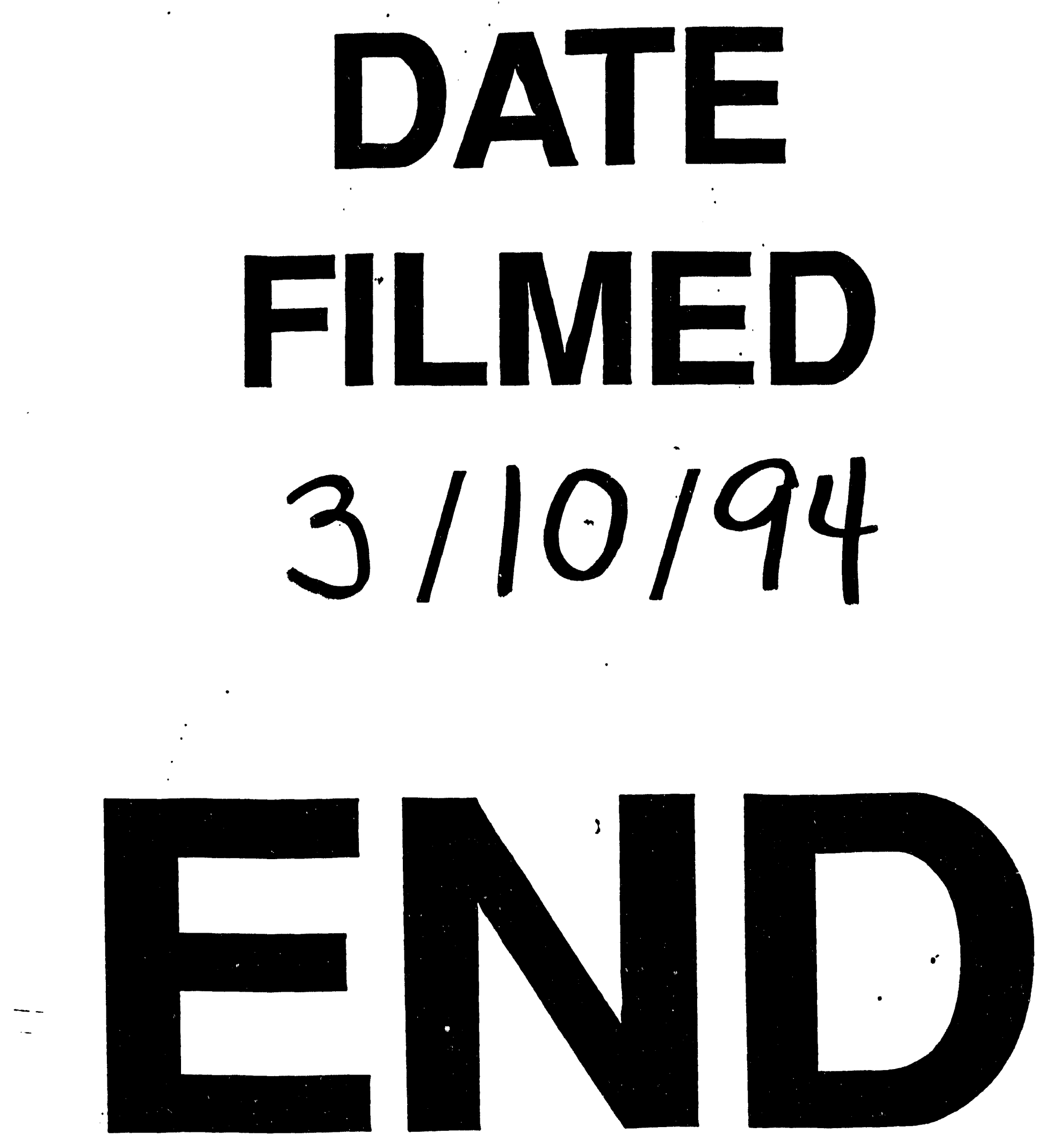


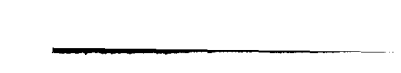

